\title{
OSTI
}

\section{EVALUATION OF EXISTING WELLS AT THE NEVADA TEST SITE FOR PLUGGING AND ABANDONMENT OR FOR RECOMPLETION AS MONITORING WELLS}

prepared by

David Gillespie, Dee Donithan, and Paul Seaber

submitted to

Nevada Operations Office

U.S. Department of Energy

September 1996

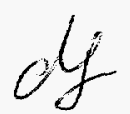

IISTIBUTONON OF THIS DOCUMENT IS UNLIMITED 


\section{DISCLAIMER}

Portions of this document may be illegible electronic image products. Images are produced from the best available original document. 
This report was prepared as an account of work sponsored by the United States Government. Neither the United States nor the United States Department of Energy, nor any of their employees, makes any warranty, express or implied, or assumes any legal liability or responsibility for the accuracy, completeness or usefulness of any information, apparatus, product or process disclosed, or represents that its use would not infringe privately owned rights. Reference herein to any specific commercial product, process, or service by trade name, mark, manufacturer, or otherwise, does not necessarily constitute or imply its endorsement, recommendation, or favoring by the United States Government or any agency thereof. The views and opinions of authors expressed herein do not necessarily state or reflect those of the United States Government or any agency thereof.

This report has been reproduced directly from the best available copy.

Available to DOE and DOE contractors from the Office of Scientific and Technical Information, P.O. Box 62, Oak Ridge, TN 37831; prices available from (423) 576-8401.

Available to the public from the National Technical Information Service, U.S. Department of Commerce, 5285 Port Royal Rd., Springfield, VA 22161. 


\title{
EVALUATION OF EXISTING WELLS AT THE NEVADA TEST SITE FOR PLUGGING AND ABANDONMENT OR FOR RECOMPLETION AS MONITORING WELLS
}

\author{
prepared by \\ David Gillespie, Dee Donithan, and Paul Seaber \\ Water Resources Center \\ Desert Research Institute \\ University and Community College System of Nevada
}

Publication No. 45153

submitted to

Nevada Operations Office

U.S. Department of Energy

Las Vegas, Nevada

September 1996

The work upon which this report is based was supported by the U.S. Department of Energy under Contract \#DE-AC08-95NV11508. 


\begin{abstract}
In this investigation, various information sources from the Nevada Test Site (NTS), national laboratories and the Desert Research Institute were utilized to verify the existence of approximately 250 existing wells or boreholes at the NTS. Of these wells, 40 were determined to be located within one kilometer of underground nuclear tests conducted near (within $25 \mathrm{~m}$ ) or below the water table.

These 40 existing wells were then investigated in detail to determine their drilling and construction history, lithology and hydrologic units penetrated, and current conditions. These findings are presented for each well, as well as recommendations as to whether individual wells should be plugged and abandoned or could possibly be recompleted as groundwater quality monitoring locations.

Two of the 40 wells, UE-20e and UE-2a, contain lost drilling strings and do not penetrate aquifers. These two wells should be plugged and abandoned and removed from the NTS well inventory. Three other wells, Test Well \#1, Test Well \#5, and Test Well \#6, are reported stemmed with sand to the surface. These three wells did not penetrate the water table and would require substantial deepening to be recompleted as groundwater monitoring locations. If not recompleted, these wells should also be plugged and abandoned and removed from the NTS well inventory.

Eleven of the 34 wells, Test Well \#7, RNM \#1, RNM \#2, RNM \#2S, U-3cn \#5, UE-20n \#1, UE-7ns, UE-5n, UE-4t, UE-3e \#3 and U-15k Test Hole, penetrate aquifers and do not require recompletion to produce groundwater monitoring locations. These wells are either constructed such that recompletion is not needed or not possible. Several of the 11 wells may require the removal of tubing and the placement or replacement of pump equipment. All five of the wells require wellhead rehabilitation to ensure they are not contaminated by surface water or other materials.

Wells PM-1, U-9ca \#1, UE-7k, U-15b Exploration Hole, UE-20e \#1 and U-10L \#l require minimal cleaning of bridges and fill, with possibly some deepening of the existing holes. With the installation of gravel-packed, slotted casing strings and Moyno pumps with monitoring lines, these wells could be recompleted to produce groundwater monitoring locations.

The remaining four wells, UE-4al, U-9 ITS UE-U-22, U-9 ITS UE-U-29 \#1, and U-9 ITS UE-U-29 \#2, would require substantial deepening of the existing holes and the installation of completion strings. This activity would require the mobilization of a rotary drilling rig, as well as geophysical logging and hydrologic testing to determine intervals of interest in the deepened wells.
\end{abstract}




\section{CONTENTS}

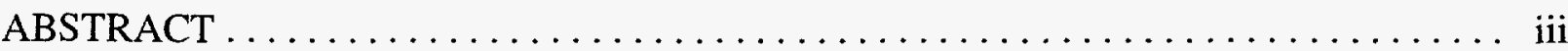

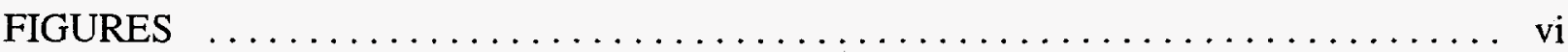

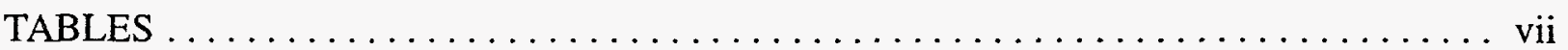

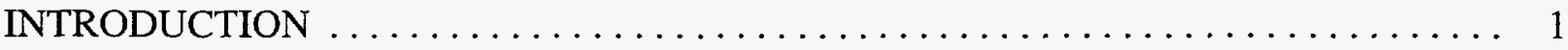

OVERVIEW OF THE GROUNDWATER REGIME AT THE NEVADA TEST SITE $\ldots \ldots$

Physiography and Geology of the Nevada Test Site $\ldots \ldots \ldots \ldots \ldots \ldots \ldots \ldots$

Hydrogeology of the Nevada Test Site $\ldots \ldots \ldots \ldots \ldots \ldots \ldots \ldots \ldots \ldots \ldots \ldots$

Regional Groundwater Flow Patterns at the Nevada Test Site $\ldots \ldots \ldots \ldots \ldots \ldots$

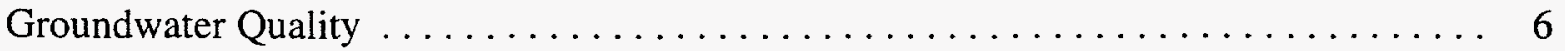

SOURCE TERM FOR THE NEVADA TEST SITE $\ldots \ldots \ldots \ldots \ldots \ldots \ldots \ldots \ldots$

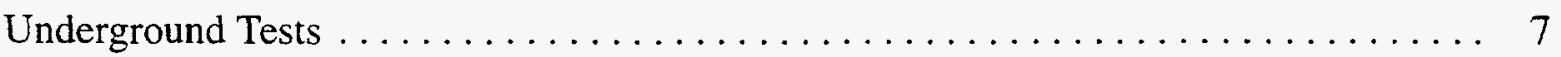

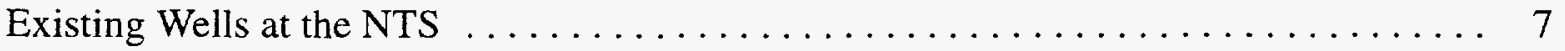

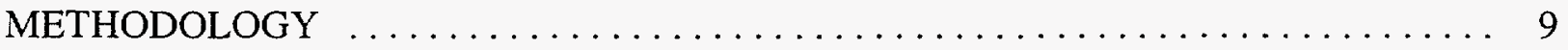

Sources of Information used in Well Evaluation $\ldots \ldots \ldots \ldots \ldots \ldots \ldots \ldots$

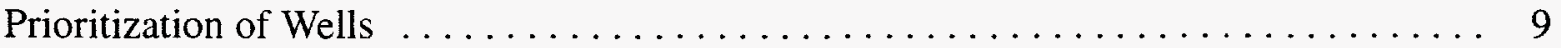

DESCRIPTION OF EXISTING WELLS LOCATED WITHIN $1000 \mathrm{M}$ OF

UNDERGROUND TESTS CONDUCTED NEAR OR BELOW THE WATER TABLE $\ldots 10$

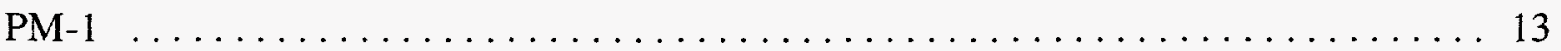

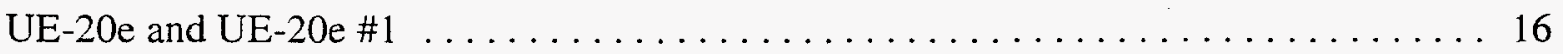

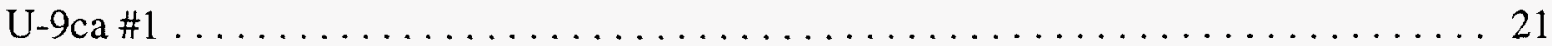

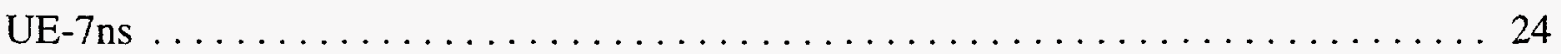

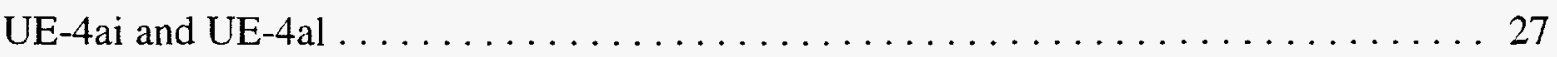

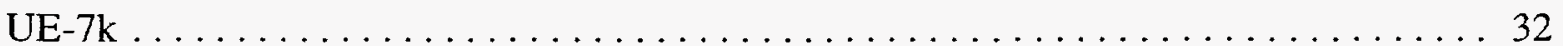

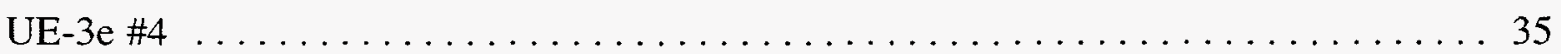

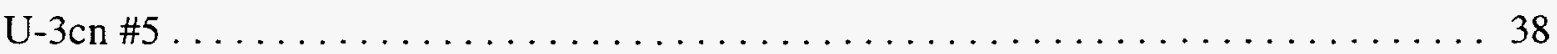

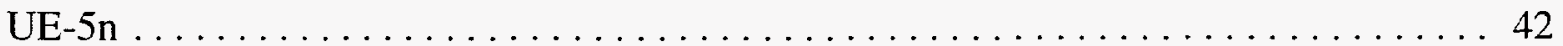

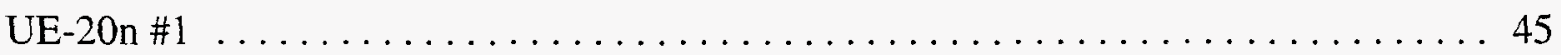

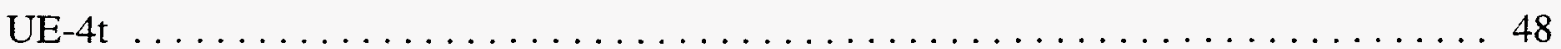

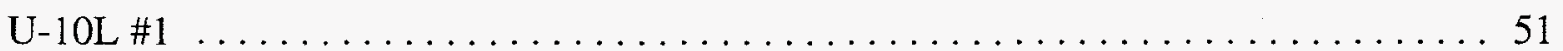

U-9 ITS UE-U-29 \#1 and U-9 ITS UE-U-29 \#2 $\ldots \ldots \ldots \ldots \ldots \ldots \ldots \ldots \ldots$

U-9 ITS UE-U-22 ... . . . . . . . . . . . . . . . . . . . . . . . . . . . 59

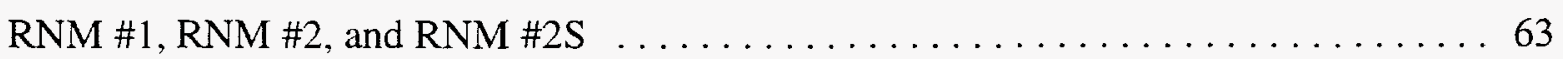

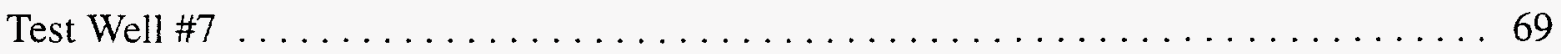

Test Hole \#1, Test Hole \#5, and Test Hole \#6 .................... 72

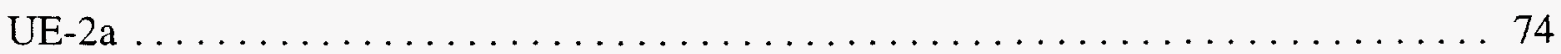

U-15k Test Hole, UE-15h, UE-15g, UE-15f, and U-15b Exploration Hole \#1 . . . . . 75

Marble \#1, Marble \#2, and Marble \#3 . . . . . . . . . . . . . . . . . . . . . . 79

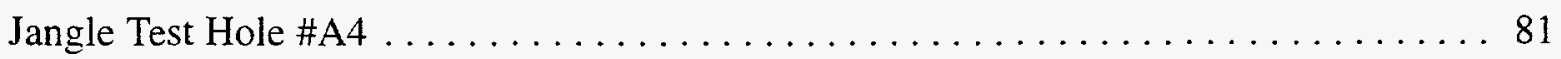

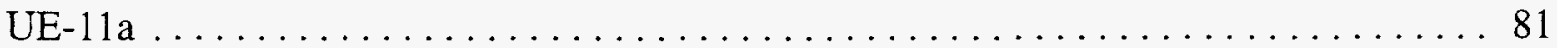




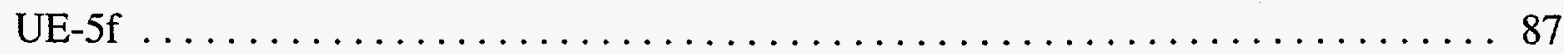

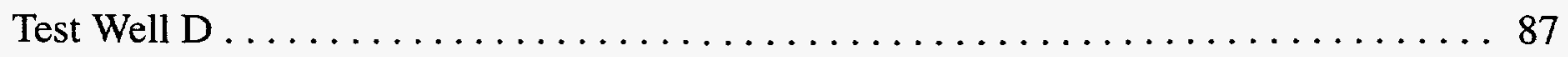

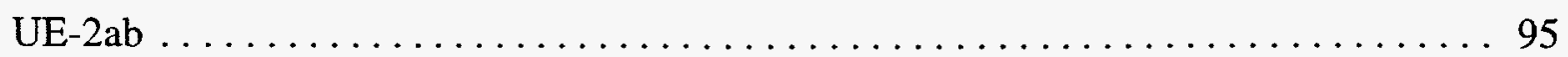

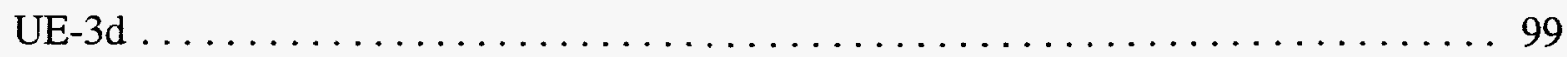

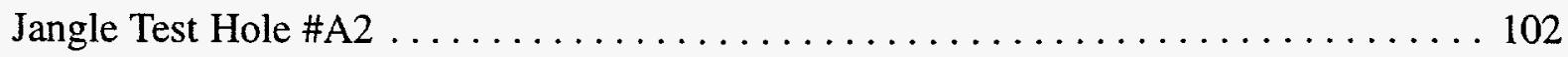

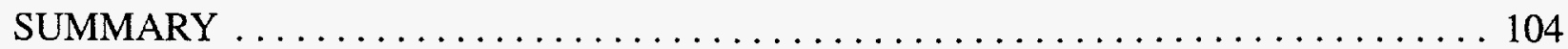

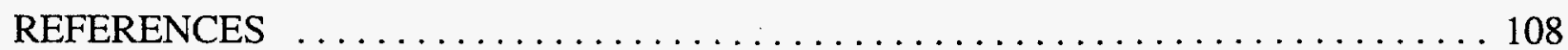

APPENDIX A: Tests Conducted Below $25 \mathrm{~m}$ Above SWL . . . . . . . . . . . 110

APPENDIX B: $\quad$ Existing Wells at the NTS . . . . . . . . . . . . . . . . 116

APPENDIX C: $\quad$ Lithologic Symbols used in Cross Sections and Well Diagrams . . . . . 123

APPENDIX D: $\quad$ Stratigraphic Nomenclature used in Hole Diagrams . . . . . . . . . . . 124 


\section{FIGURES}

1. Physiographic features at the Nevada Test Site $\ldots \ldots \ldots \ldots \ldots \ldots \ldots \ldots \ldots, 2$

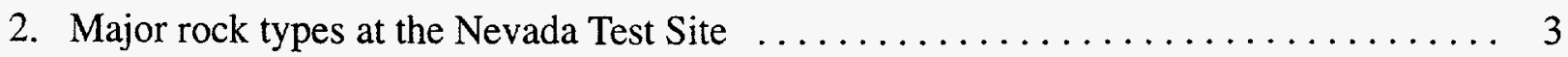

3. Composite potentiometric surface and hydrographic subbasins at the Nevada Test Site (after Waddell et al., 1984) . . . . . . . . . . . . . . . . . . . . . 5

4. Underground nuclear testing locations at the Nevada Test Site $\ldots \ldots \ldots \ldots \ldots \ldots 8$

5. Existing wells located within $1000 \mathrm{~m}$ of tests conducted within $25 \mathrm{~m}$ below the water table at the NTS . . . . . . . . . . . . . . . . . . . . 12

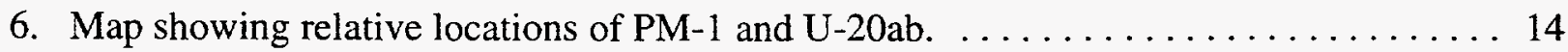

7. Well construction and lithology at PM-1 $\ldots \ldots \ldots \ldots \ldots \ldots \ldots \ldots \ldots \ldots \ldots \ldots \ldots \ldots \ldots \ldots$

8. Map showing relative locations of UE-20e \#1, UE-20e, and U-20e $\ldots \ldots \ldots \ldots \ldots 17$

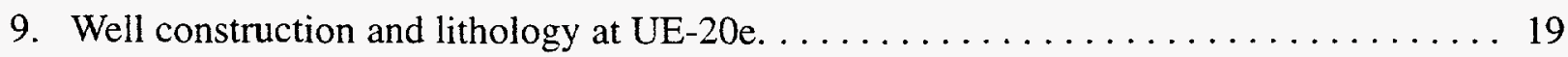

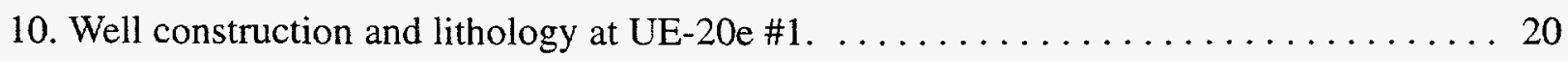

11. Map showing relative location of U-9ca \#1, U-10af and U-9cb $\ldots \ldots \ldots \ldots \ldots 22$

12. Well construction and lithology at $U-9 \mathrm{ca} \# 1 . \ldots \ldots \ldots \ldots \ldots \ldots \ldots \ldots \ldots \ldots \ldots \ldots$

13. Map showing relative location of UE-7ns, U-7n, and U-7t. $\ldots \ldots \ldots \ldots \ldots \ldots 25$

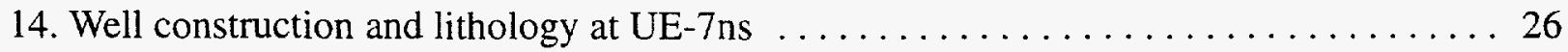

15. Map showing relative location of UE-4ai, UE-4al, U-4ak, U-4ar, U-4au, and U-4i . . . 28

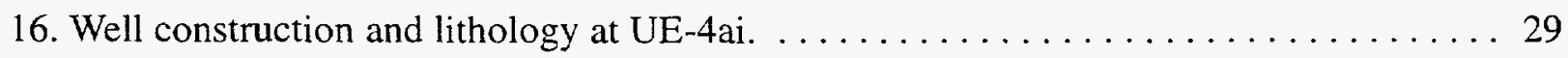

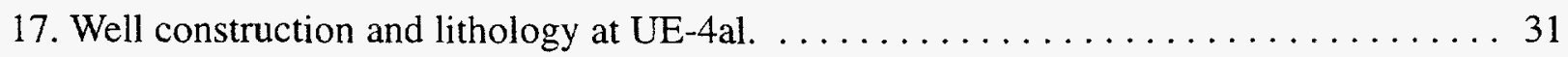

18. Map showing relative location of U-7e, U-7z, UE-7k, U-7ac, and U-3dh $\ldots \ldots \ldots 33$

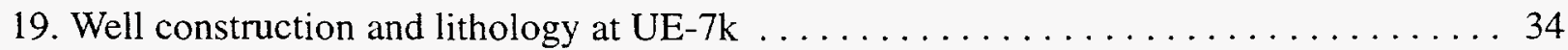

20. Map showing relative location of U-3mt, U-7an, U-7bu, U-7aq, U-3kz, U-3la, U-3gg,

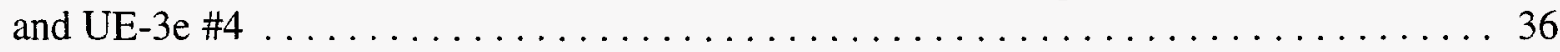

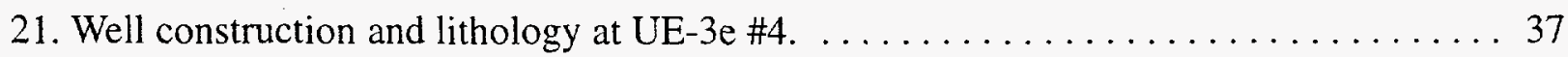

22. Map showing relative location of U-3cn \#5, U-3ej, and U-3cn. . . . . . . . . 39

23. Well construction and lithology at $U-3 c n \# 5 . \ldots \ldots \ldots \ldots \ldots \ldots \ldots \ldots \ldots \ldots \ldots \ldots$

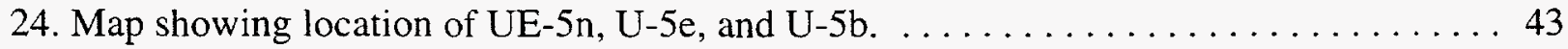

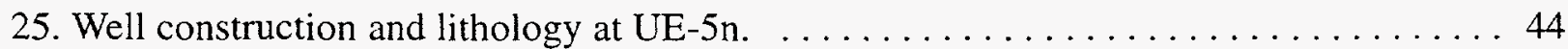

26. Map showing location of U-20ac, U-20a, U-20n, U-20av, and UE-20n \#1 . . . . . . 46

27. Well construction and lithology at UE-20n $\# 1 \ldots \ldots \ldots \ldots \ldots \ldots \ldots \ldots \ldots \ldots \ldots$

28. Map showing location of U-4o, U-4d, U-4q, U-4l, U-4g, U-4t, U-4c, U-7ap, U-4j,

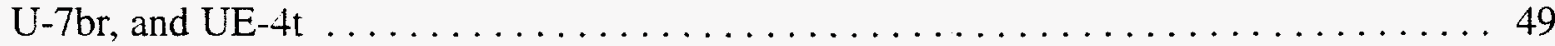

29. Well construction and lithology at UE-4t. ..................... 50 
30. Map showing location of U-9cb, U-10af and $\mathrm{U}-10 \mathrm{~L} \# 1 \ldots \ldots \ldots \ldots \ldots \ldots \ldots \ldots \ldots$

31. Well construction and lithology at $\mathrm{U}-10 \mathrm{~L} \# 1 \ldots \ldots \ldots \ldots \ldots \ldots \ldots \ldots \ldots \ldots \ldots \ldots$

32. Map showing location of U-9 ITS UE-U-29 \#1, U-9 ITS UE-U-29 \#2, and U-9cb. . . . 55

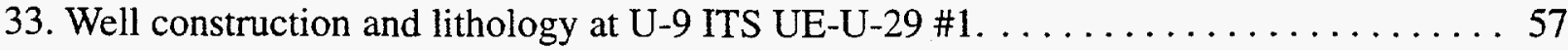

34. Well construction and lithology at U-9 ITS UE-U-29 $\# 2 \ldots \ldots \ldots \ldots \ldots \ldots \ldots$

35. Map showing location of U-9bx and U-9 ITS UE-U-22 $\ldots \ldots \ldots \ldots \ldots \ldots \ldots$

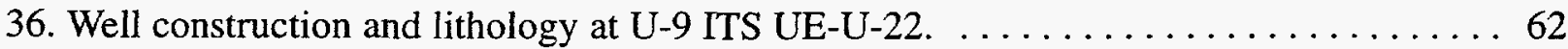

37. Map showing location of U-5e, RNM \#1, RNM \#2, and RNM \#2S. . . . . . . . . 64

38. Well construction and lithology at RNM $\# 1 \ldots \ldots \ldots \ldots \ldots \ldots \ldots \ldots \ldots \ldots \ldots \ldots \ldots$

39. Well construction and lithology at $\mathrm{RNM} \# 2 \ldots \ldots \ldots \ldots \ldots \ldots \ldots \ldots \ldots \ldots \ldots \ldots$

40. Well construction and lithology at RNM $\# 2 S \ldots \ldots \ldots \ldots \ldots \ldots \ldots \ldots \ldots \ldots \ldots \ldots \ldots \ldots$

41. Map showing relative location of TW7, U-7k, U-3dn, U-6ai, U-3an, U-3bs,

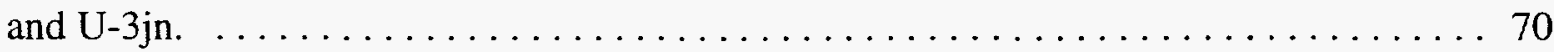

42. Well construction and lithology at Test Well \#7. .................. 71

43. Map showing relative location of Test Hole \#1 through Test Hole \#9, HTH-E,

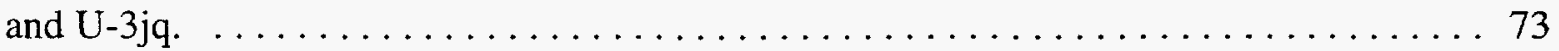

44. Map showing relative location of U-15k, U-15b, U-15a, UE-15h, and UE-15f. . . . . 76

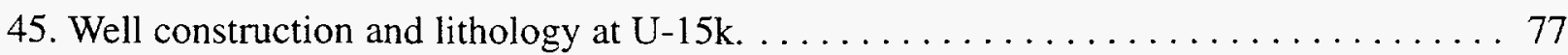

46. Well construction and lithology at $\mathrm{U}-15 \mathrm{~b} \mathrm{EX} \# 1 . \ldots \ldots \ldots \ldots \ldots \ldots \ldots \ldots \ldots \ldots \ldots \ldots$

47. Map showing relative location of Marble \#1, Marble \#2, Marble \#3, and U-15a. .... 80

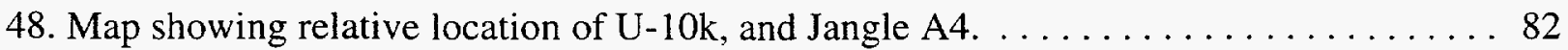

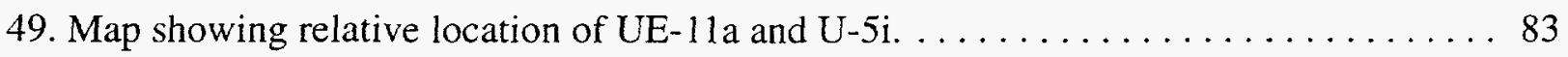

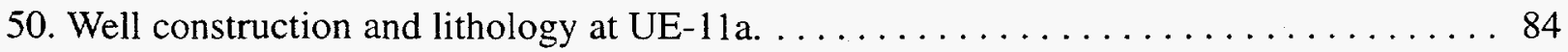

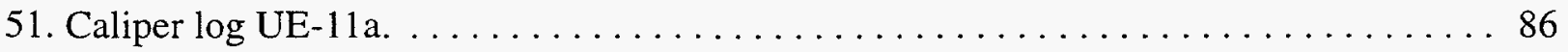

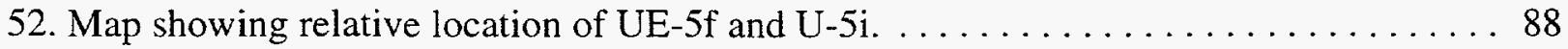

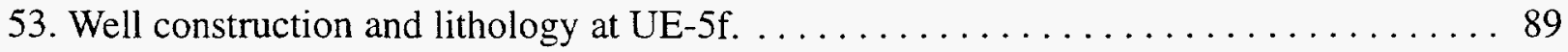

54. Lithologic cross section showing relationship between UE-11a, U-5i, and UE-5f. . . . 90

55. Map showing relative location of Test Well D and U-4ak. . . . . . . . . . . 92

56. Well construction and lithology at Test Well D. . . . . . . . . . . . . . 93

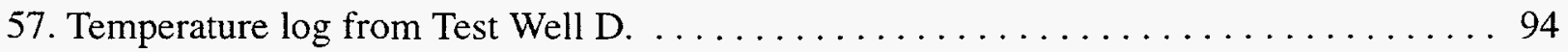

58. Map showing relative location of UE-2ab and $\mathrm{U}-2 \mathrm{fc} \ldots \ldots \ldots \ldots \ldots \ldots \ldots \ldots$

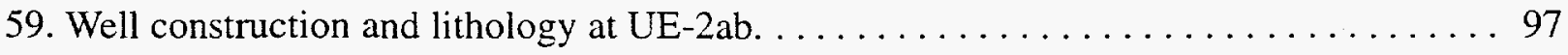

60. Lithologic cross section showing relationship between UE-2ab and U-2fc. . . . . . 98 
61. Map showing relative location of UE-3d, U-3dd, and U-3fd. . . . . . . . . 100

62. Well construction and lithology at UE-3d $\ldots \ldots \ldots \ldots \ldots \ldots \ldots \ldots \ldots \ldots \ldots \ldots \ldots$

63. Map showing relative location of Jangle A2, U-2eo, and U-2ei. . . . . . . . 103

\section{TABLES}

1. Hydrostratigraphic Classification of Principal Lithologic Units at the Nevada Test Site

2. Existing Wells at the NTS Located within $1 \mathrm{~km}$ of Underground Tests Conducted Near or Below the Water Table 


\section{INTRODUCTION}

Geologic and hydrologic investigations related to nuclear testing at the NTS have left a legacy of hundreds of open wells at the Nevada Test Site (NTS), ranging in total depth from tens to thousands of meters. Many of these wells penetrate the water table and may present avenues of cross-aquifer contamination. Some of these wells may provide pathways for the shortcutting of recharge from precipitation at the surface to the water table as the result of inadequate wellhead construction. Additionally, some of these existing wells may provide suitable groundwater monitoring locations if recompleted. Recompletion of existing wells provides a substantial cost savings compared to the design and construction of new groundwater monitoring wells (Gillespie and Seaber, 1993).

The proper procedures and requirements for plugging and abandonment of water wells, or wells drilled for purposes other than as water wells, are set forth in Nevada Revised Statutes NAC Chapter 534. In general, these provisions require that water wells must be plugged from total depth, including annular spaces between the wellbore and any casing, with neat cement or a bentonite product designed to plug abandoned wells. If a bentonite product is used, the top $15.25 \mathrm{~m}$ of the well must be plugged with cement. For wells other than water wells, which do not penetrate an aquifer, the well may be backfilled from total depth with cuttings drilled from the well, or inorganic fill material, or plugged in the same manner as a water well. If the well penetrates an aquifer, the well must be plugged to the same specifications as a water well.

In this investigation, existing wells at the Nevada Test Site were examined to determine those wells located within $1000 \mathrm{~m}$ of underground tests conducted near (within $50 \mathrm{~m}$ ), or below, the water table. The purpose of this investigation is to provide the Department of Energy (DOE) and its contractors information and recommendations upon which to base decisions whether individual wells at the NTS should be recompleted for inclusion in a groundwater monitoring network, or plugged and abandoned.

\section{OVERVIEW OF THE GROUNDWATER REGIME ON THE NEVADA TEST SITE}

\section{Physiography and Geology of the Nevada Test Site}

The NTS lies within the Basin and Range structural setting characteristic of southwestern Nevada. The topography of the NTS is composed of four major basins, three large mesas, and a number of north-south-trending mountain ranges. The four major basins, or valleys, are located in the eastern and southern areas and are known as Frenchman, Yucca, and Jackass flats, and Mercury Valley. The minimum elevations of these basins (above mean sea level) are 1200, 1000,1100 , and $1000 \mathrm{~m}$, respectively. The three large mesas are Pahute Mesa (2256 m), Buckboard Meas (1848 m), and Rainier Mesa $(2324 \mathrm{~m})$. The major mountain ranges on the NTS include the Belted Range ( $2354 \mathrm{~m}$ ), Mercury Ridge (1608 m), and the Halfpint Range (1539 m). Isolated mountains such as Skull Mountain (1828 m), Shoshone Mountain ( $2154 \mathrm{~m})$, and Yucca Mountain $(1930 \mathrm{~m})$ are also present on the NTS. The locations of these features are shown in Figure 1. 


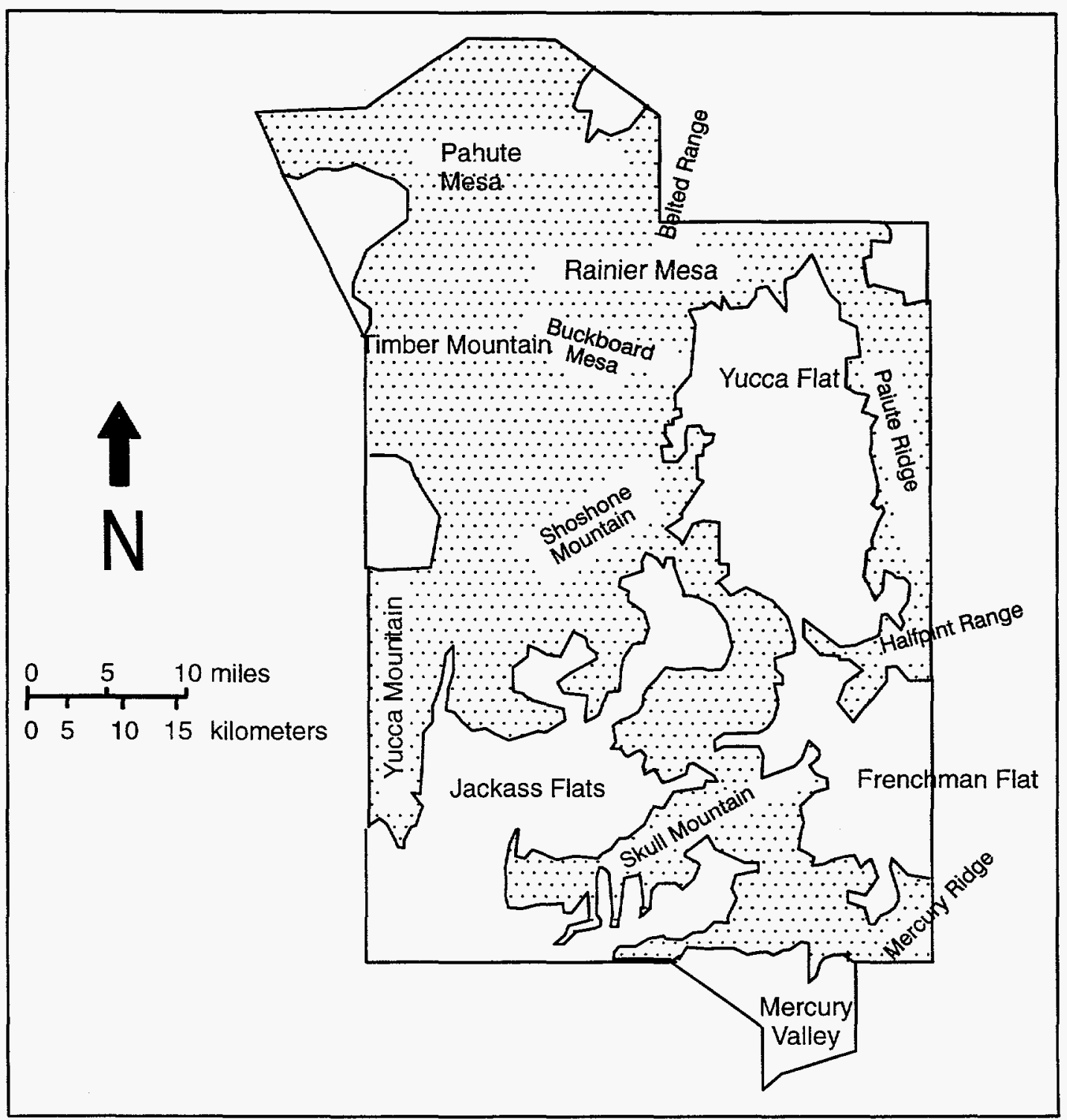

Figure 1. Physiographic features at the Nevada Test Site.

The major geologic units of the NTS can be classified into three types: (1) complexly folded and faulted sedimentary rocks of Paleozoic age, (2) volcanic tuffs and lavas of Tertiary age, and (3) Tertiary and Quaternary alluvium (Figure 2). The sedimentary rocks of Paleozoic age are hundreds to thousands of meters thick and are comprised primarily of carbonate rocks in the lower and upper sections, which are separated by a thick sequence of clastic rocks (shale and quartzite). These Paleozoic-age sediments, have undergone several deformational events, resulting in a series of north-south-oriented thrust faults, accompanied by complex folding and normal faulting. 


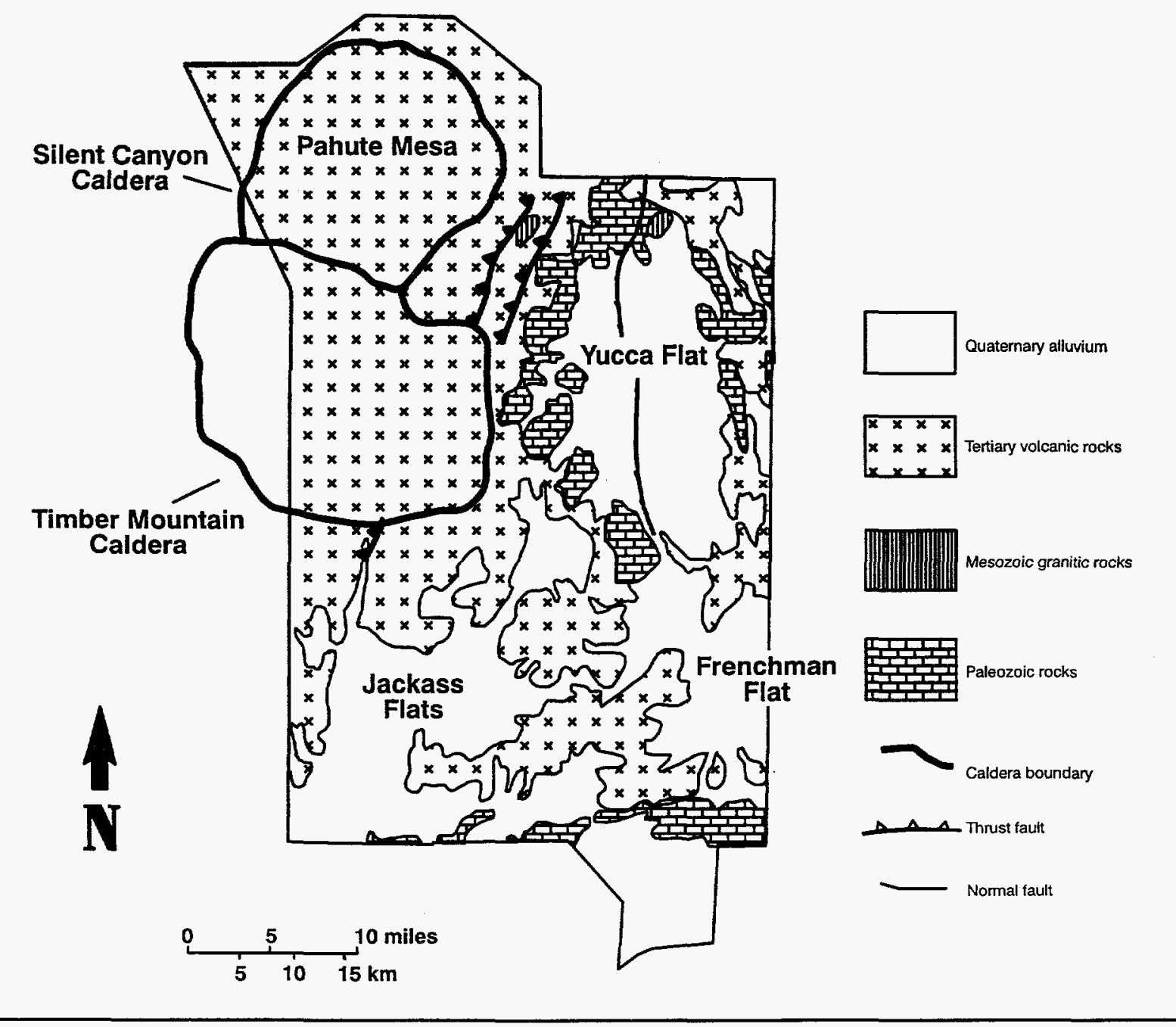

Figure 2. Major rock types at the Nevada Test Site.

The volcanic units of Tertiary age are predominantly rhyolitic tuffs ejected from volcanic centers, primarily Silent Canyon and Timber Mountain calderas, located in the northwestern portion of the NTS. The aggregate thickness of these volcanic rocks is several thousand meters, however, erosion and non-deposition result in extremely variable thickness of individual units. Tertiary units have been deformed to a much lesser degree than the Paleozoic section. Tertiary units are down-dropped in the valleys and tilted along steeply dipping faults of late Tertiary age.

Alluvial sediments are derived from the erosion of nearby mountains. These sediments are composed of Paleozoic and Tertiary rock fragments, and fill the intermontane valleys to a maximum thickness of 600 to $900 \mathrm{~m}$. Alluvial sediments appear to be relatively undeformed with the exception of geologically recent faulting producing offsets in these materials, especially along the north-south-trending Yucca Fault in central Yucca Flat. 


\section{Hydrogeology of the Nevada Test Site}

A generalized hydrostatigraphic classification of the principal lithologic units encountered at the NTS, as modified from Winograd and Thordarson (1975), is presented in Table 1. Valley fill (alluvium) is an aquifer whenever it is encountered within the saturated zone (within the deepest portions of the basin valleys), and transmits groundwater through intergranular primary porosity/permeability. Tertiary volcanics produce aquifers in lava-flow, welded tuff, and bedded

Table 1. Hydrostratigraphic Classification Of Principal Lithologic Units At The Nevada Test Site.

\begin{tabular}{|c|c|c|}
\hline Geologic Time Period & Stratigraphic Unit & Hydrogeologic Unit \\
\hline \multirow[t]{6}{*}{ Cenozoic } & Valley Fill & Valley-Fill Aquifer \\
\hline & $\begin{array}{l}\text { Basalt of Kiwi Mesa } \\
\text { Rhyolite of Shoshone Mountain } \\
\text { Basalt of Skull Mountain }\end{array}$ & Lava-Flow Aquifer \\
\hline & $\begin{array}{l}\text { Timber Mountain Tuff } \\
\text { Paintbrush Tuff }\end{array}$ & Welded Tuff Aquifer \\
\hline & Informal Bedded Tuff & Bedded Tuff Aquifer \\
\hline & Wahmonie Formation & $\begin{array}{l}\text { Lava-Flow Aquitard/Tuff } \\
\text { Aquitard }\end{array}$ \\
\hline & $\begin{array}{l}\text { Salyer Formation } \\
\text { Belted Range Tuff } \\
\text { Local Informal Units } \\
\text { Rhyolite Flows and Tuffaceous } \\
\text { Beds of Calico Hills } \\
\text { Tuff of Crater Flat } \\
\text { Lithic Ridge Tuff } \\
\text { Rocks of Pavits Spring } \\
\text { Horse Spring Formation }\end{array}$ & Tuff Aquitard \\
\hline Mesozoic & Granitic Stocks & Minor Aquitard \\
\hline \multirow[t]{3}{*}{ Paleozoic } & Tippipah Limestone & Upper Carbonate Aquifer \\
\hline & Eleana Formation & Upper Clastic Aquitard \\
\hline & $\begin{array}{l}\text { Devil's Gate Limestone } \\
\text { Nevada Formation } \\
\text { Undifferentiated Dolomite } \\
\text { Ely Springs Dolomite } \\
\text { Eureka Quartzite } \\
\text { Pogonip Group } \\
\text { Nopah Formation } \\
\text { Bonanza King Formation } \\
\text { Carrera Formation }\end{array}$ & Lower Carbonate Aquifer \\
\hline Precambrian & $\begin{array}{l}\text { Zabriskie Quartzite } \\
\text { Wood Canyon Formation } \\
\text { Stirling Quartzite } \\
\text { Johnnie Formation }\end{array}$ & Lower Clastic Aquitard \\
\hline
\end{tabular}


tuff intervals. Tuff aquitards occur in non-welded, and zeolitized tuff units. In general, groundwater flow within Tertiary volcanic units is dominated by fracture flow (secondary permeability). The more dense lava and welded tuff units contain a greater number of fractures; non-welded and zeolitized units (less dense) contain less or sealed fractures. Paleozoic aquifers consist of fractured carbonate units. Paleozoic aquitards consist of clastic intervals (shales and quartzites).

\section{Regional Groundwater Flow Patterns at the Nevada Test Site}

Areas of groundwater recharge, discharge, and flow on and near the NTS have been divided into three subbasins (Figure 3), which are considered part of the larger Death Valley groundwater basin (Waddell et al., 1984). Groundwater within the Ash Meadows subbasin drains from areas to the north and east of the NTS and flows generally southwestward towards springs at Ash Meadows, approximately 40 kilometers southwest of Mercury (Winograd and Thordarson, 1975). Groundwater flow within this subbasin is thought to occur primarily in the lower carbonate aquifer. The distribution of head and direction of flow are greatly affected by the presence of low permeability rocks (lower clastic aquitard) within the subbasin (Winograd and Thordarson, 1975).

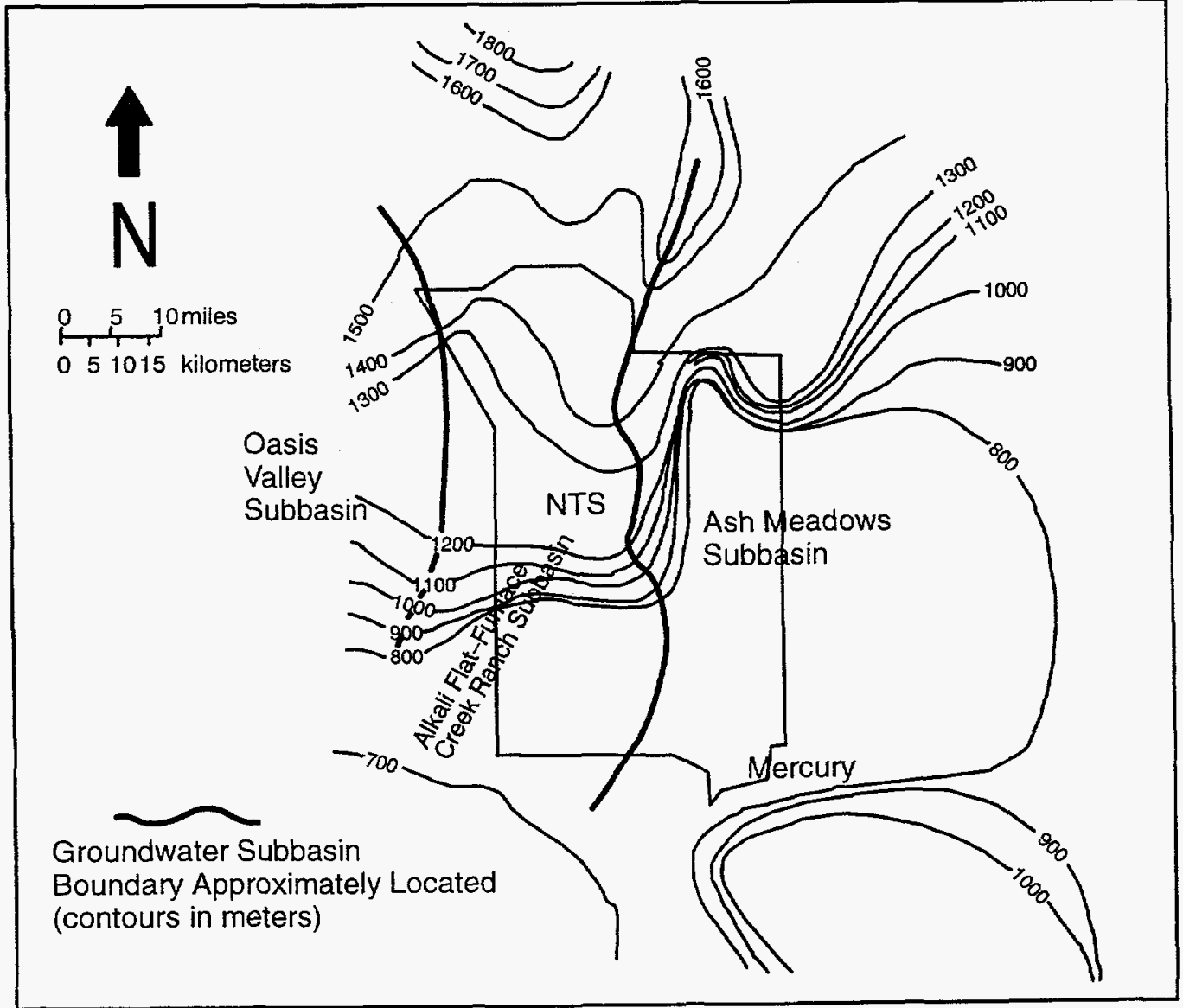

Figure 3. Composite potentiometric surface and hydrographic subbasins at the Nevada Test Site (after Waddell et al., 1984). 
Groundwater from the majority of the western portion of the NTS flows from beneath Pahute Mesa (and possibly other areas to the north) southward, towards Alkali Flat in the central Amargosa Desert. Groundwater flow is through the valley-fill, volcanic, and lower carbonate aquifers. Discharge occurs at Alkali Flat by evapotranspiration. Some underflow may surface at springs in Death Valley (Winograd and Thordarson, 1975).

The remaining portion of groundwater flowing from western Pahute Mesa and areas to the north is thought to move southward, beneath the western portion of the NTS, within the Oasis Valley subbasin. Discharge from this flow system occurs primarily though evapotranspiration at Oasis Valley and as underflow to the Alkali Flat-Furnace Creek Ranch subbasin (White, 1979). Groundwater flow in Pahute Mesa is primarily through interbedded volcanic rocks, which exhibit extreme contrasts in vertical and horizontal hydraulic conductivity (Blankennagel and Weir, 1973).

The boundaries of the subbasins described above have been placed at different locations by different authors and, due to the sparseness of data, are poorly defined. The average well density for the NTS (an area of approximately $57,924 \mathrm{~km}^{2}$ ) is very low. The level of coverage sufficient for the determination of generalized regional flow patterns is not adequate to determine localized detailed flow models required for hydrologic characterization. The paucity of wells on the NTS prohibits the determination of vital information, such as rate or direction of inter-aquifer flux, the perturbations created by localized geologic structure or nuclear testing, or the delineation of permeable and impermeable zones within individual hydrologic units.

\section{Groundwater Quality}

The interpretation of groundwater chemical analysis has been extremely valuable in developing conceptual models of groundwater flow. Schoff and Moore (1964) performed the first comprehensive studies of the chemical quality of the groundwater underlying the NTS. They classified groundwater on the NTS as belonging to one of three broad categories: (1) a sodium and potassium bicarbonate type; (2) a calcium and magnesium bicarbonate type; and (3) a type which consisted of mixtures of the first two, in varying proportions. The first groundwater type was found in the tuff aquifers and aquitards. The second type was found in Paleozoic carbonate aquifers as well as in the valley-fill aquifers, which were composed primarily of carbonate rock detritus. Mixed waters were thought to have formed in one of three ways: (1) by movement of water from tuffaceous rocks into carbonate rocks (or carbonate alluvium); (2) by movement of water from carbonates into tuffs; or (3) through mixing of the first two groundwater types. Chapman and Lyles (1993) examined groundwater chemical analysis results from a total of 81 wells obtained over the period from 1957 to 1990. As in previous investigations they determined the existence of three basic hydrochemical facies represented by the samples. Additionally, their interpretation of the data indicates a dominance of vertical over lateral flow within the basins on the NTS between the overlying volcanic and underlying carbonate aquifers. 


\section{SOURCE TERM FOR THE NEVADA TEST SITE}

\section{Underground Tests}

Underground tests at the NTS have been conducted in either vertically drilled shafts or in tunnels. The areas in which nuclear testing has been conducted on the NTS are identified in Figure 4 (denoted by shading of 1000-m-radius circles around locations of underground tests). These five areas are located in Yucca Flat, Frenchman Flat, Rainier Mesa, Pahute Mesa, and Shoshone Mountain. These areas are considered the source areas for radionuclides found within the groundwater. The majority of underground testing has been conducted in unsaturated alluvium and Tertiary units. However, several nuclear tests were conducted within pre-Cenozoic units and at or below the water table. Lawrence Livermore National Laboratory (LLNL) and Los Alamos National Laboratory's (LANL) NTS Event Database indicates that 183 underground tests were conducted at the NTS near (within $50 \mathrm{~m}$ ) or below the water table. Tests conducted near (within $50 \mathrm{~m}$ ) or below the water table at the NTS are listed in Appendix A.

\section{Existing Wells at the NTS}

Existing wells at the NTS can be grouped into six categories: Emplacement (either expended or unexpended), Satellite/Instrument, Postshot, Exploration, Water Supply, and Other.

\section{Emplacement Holes}

Emplacement holes were drilled to provide access to the underground for the nuclear test device. These holes range from less than 1 to more than $2 \mathrm{~m}$ in diameter. Depending on the yield of the device to be contained, these holes range in depth from hundreds to up to more than 2000 $\mathrm{m}$. Generally, these emplacement holes extend only slightly below the depth of burial for the device; however, if the depth of burial was to be near the water table, these holes may have been drilled until the water table was penetrated and then stemmed back to above the water table prior to emplacement of the device. Following emplacement of the test device, these holes are stemmed with containment material to near the surface.

\section{$\underline{\text { Satellite and Instrument Holes }}$}

Satellite holes at the NTS were constructed for lithologic investigation prior to drilling an emplacement hole. The primary purpose of these holes was to determine the lithologic character of the units intended to contain the detonation conducted in the emplacement holes, and to obtain geophysical logs which could not be conducted in the larger diameter emplacement holes.

Prior to detonation of the underground test, instrument holes were drilled, or if suitable, satellite holes were used as instrument holes to obtain seismic data from the test. Sensors were placed at the desired depths within the holes and the holes were then stemmed to the surface. As a general rule, satellite and instrument holes were located relatively close to their associated emplacement hole. Prior to detonation of the underground test, all holes within a distance of approximately one depth of burial for the device were plugged to prevent loss of containment 


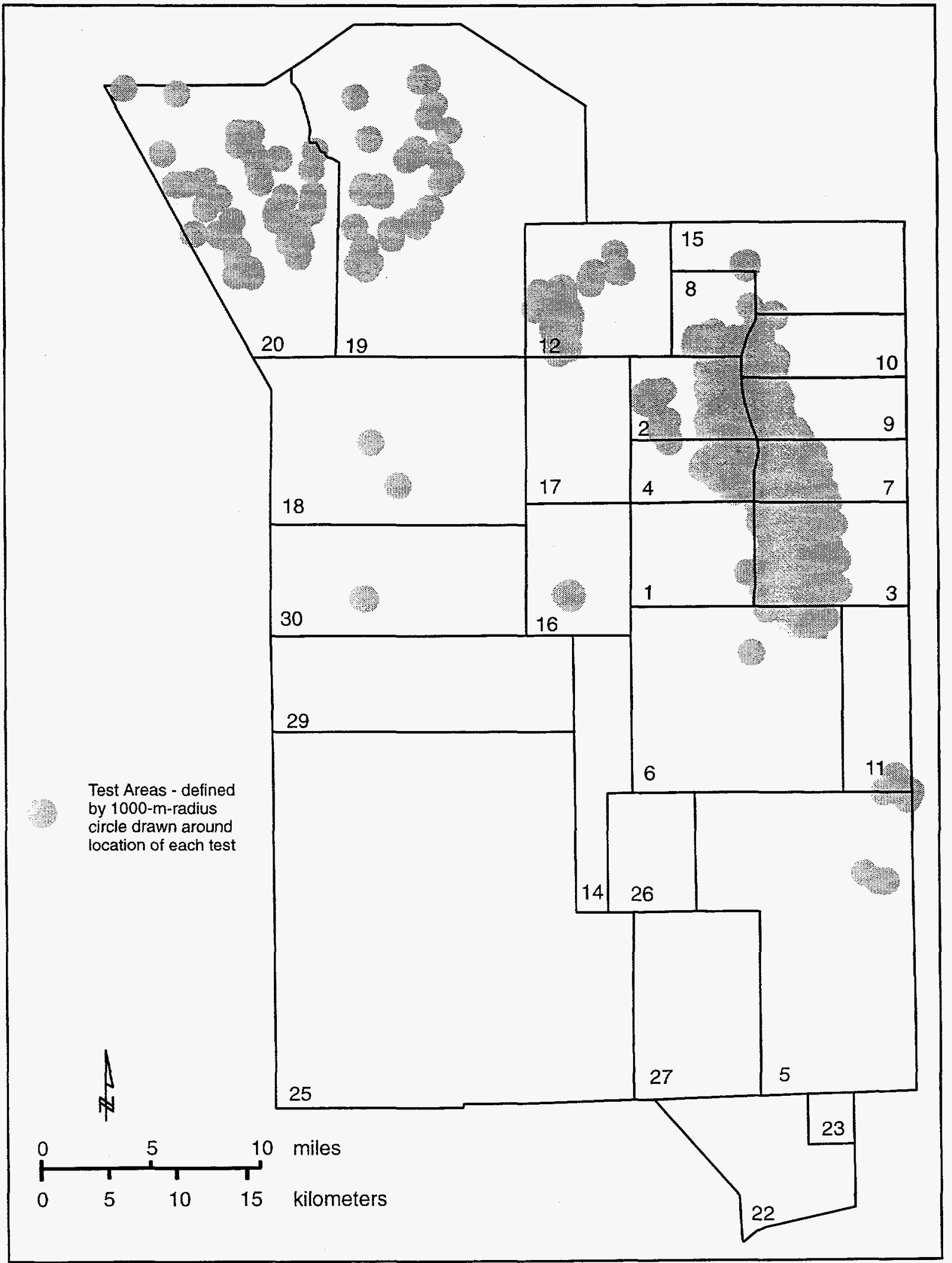

Figure 4. Underground nuclear testing locations at the Nevada Test Site. 
during the test. As a result, almost all satellite and instrument holes at the NTS associated with expended emplacement holes are stemmed to the surface.

\section{Postshot Holes}

Postshot holes are drilled to recover samples from the material in the cavity produced as a result of the test. These holes are also used to obtain gas samples from the chimney produced by the detonation. These samples are used to evaluate the test. Following completion of sampling, postshot holes are either plugged and abandoned, or a valve is placed on the gas sampling tubing which is cemented within the hole.

\section{Exploration}

Exploration holes at the NTS have been, and are currently, drilled for a variety of reasons. Early exploration holes were used to evaluate areas for proposed underground nuclear testing and to investigate the geology and hydrology of the NTS. The DOE Environmental Restoration (ER) Program is currently constructing new boreholes, and recompleting existing boreholes, at the NTS to further investigate the geohydrology and to evaluate contaminate transport in the saturated and vadose zones.

\section{Water Supply}

Water-supply wells were drilled to supply drinking water and construction water needs at the NTS. Many of the former and current water-supply wells at the NTS were originally drilled as exploration wells (Gillespie et al., 1996).

\section{Other}

Many holes exist at the NTS which were constructed for various purposes other than those listed above (i.e., geophysical studies, equipment tests, thermal investigations). Most of these holes are shallow (less than $500 \mathrm{~m}$ ).

\section{METHODOLOGY}

\section{Sources of Information used in Well Evaluation}

A wide variety of information sources were used to determine the construction and hydrogeologic setting of the wells investigated in this study. The starting point for the evaluation of a well was the Raytheon Services Nevada (RSN) NTS Hole Inventory, or "Redbook." Additional information was obtained from RSN hole histories for each of the individual wells. Various RSN, LLNL, LANL, and Desert Research Institute (DRI) reports were also used as sources of information concerning well construction, lithology penetrated, and the hydrologic setting of the wells.

\section{Prioritization of Wells}

Due to the large number of existing wells at the NTS, it was necessary to develop a methodology for prioritizing these wells for investigation. The primary concerns in evaluating 
a well for either recompletion or abandonment are the well's construction, hydrologic characteristics of the units penetrated by the well, and the location of the well relative to nearby underground testing. If located in proximity to a source term, a well which penetrates two or more aquifers could present a pathway for contamination to spread from a contaminated aquifer to an uncontaminated aquifer. An improperly completed well could pose a threat to the groundwater at the NTS by presenting an avenue for the shortcutting of recharge from surface water to the water table. Wells located hydrologically downgradient from testing and penetrating the same hydrologic units in which the test was conducted could serve as source-term monitoring locations. Additionally, existing wells which do not currently penetrate the water table may be suitable for recompletion by deepening due to their location relative to nearby underground testing, size of existing casing within the well, or other considerations.

The initial prioritization consisted of examining RSN's NTS Hole Inventory and eliminating all emplacement and postshot holes, as well as any holes listed as plugged or destroyed, from further consideration. ER Program wells were also excluded from consideration. This process reduced the number of candidate wells for evaluation to approximately 680 . These wells were further prioritized by eliminating instrument and satellite holes which appeared to be located within one depth of burial from an emplacement hole and therefore likely to be plugged. This resulted in a subset of 258 wells (Appendix B).

The subset of 258 wells was then plotted on base maps along with the location of underground tests conducted near or below the water table. A total of 40 of these wells (Table 2, Figure 5) was determined to be located within one kilometer of an underground nuclear test conducted near or below the water table. Only four of these wells, PM-1, Test Well D, Test Well \#7, and UE-7ns, are currently sampled on a regular basis (sampled in FY93 and FY94) by the NTS Long-Term Hydrologic Monitoring Program (DOE, 1993; 1994).

\section{DESCRIPTION OF EXISTING WELLS LOCATED WITHIN 1000 M OF UNDER- GROUND TESTS CONDUCTED NEAR OR BELOW THE WATER TABLE}

The 40 wells evaluated in this investigation range in depth from 2395.1 to $36.6 \mathrm{~m}$. Twelve of the 40 wells are less than $200 \mathrm{~m}$ deep and do not appear to penetrate the water table as currently completed.

To evaluate these wells, drilling and construction histories were determined through an examination of NTS records and published reports from LLNL, LANL, DRI and the U.S. Geological Survey (USGS). Following a search of the available literature, individual wells were located in the field using a global positioning system (GPS) to verify the well's existence and location. Measurements and photographs of the existing wellheads were made and compared with historical records to verify the well's identity and to determine the existing wellhead conditions at the well site.

Following verification of the well's location and identity, total depth and water-level checks were conducted using DRI's wireline unit in wells which could be accessed. In those 
Table 2. Existing Wells at the NTS Located within $1 \mathrm{~km}$ of Underground Tests Conducted Near or Below the Water Table.

\begin{tabular}{|c|c|c|c|c|c|}
\hline Well Name & $\begin{array}{l}\text { North } \\
(\mathrm{m})\end{array}$ & $\begin{array}{l}\text { East } \\
(\mathrm{m})\end{array}$ & $\begin{array}{l}\text { Elev } \\
(\mathrm{m})\end{array}$ & $\begin{array}{l}\mathrm{TD} \\
(\mathrm{m}) \\
\end{array}$ & $\begin{array}{l}\text { SWL } \\
(\mathrm{m})\end{array}$ \\
\hline PM-1 & 280752 & 175525 & 1999 & 2395 & 638.5 \\
\hline UE-20e \#1 & 284825 & 170980 & 1919 & 1097 & 553.8 \\
\hline UE-20n \#1 & 276315 & 174114 & 1969 & 1006 & 622.6 \\
\hline U-9ca \#1 & 265999 & 206989 & 1294 & 978.4 & 563.9 \\
\hline U-3en \#5 & 256414 & 209702 & 1223 & 923.5 & 494.0 \\
\hline UE-7k & 258836 & 208910 & 1258 & 776.6 & N/A \\
\hline Test Well \#7 & 257005 & 208682 & 1239 & 692.5 & 498.3 \\
\hline U-10L \#1 & 266980 & 207739 & 1300 & 673.0 & 560.8 \\
\hline UE-7ns & 260787 & 211440 & 1331 & 672.1 & 600.5 \\
\hline UE-4al & 258684 & 204999 & 1266 & 666.6 & N/A \\
\hline UE-3e \#4 & 257522 & 207264 & 1244 & 664.8 & 333.6 \\
\hline $\mathrm{UE}-20 \mathrm{e}$ & 284855 & 170979 & 1919 & 659.9 & $N / A$ \\
\hline UE-4t & 260776 & 207371 & 1263 & 607.5 & 89.7 \\
\hline U-15b Ex. \#1 & 275502 & 206668 & $\mathrm{~N} / \mathrm{A}$ & 548.6 & $\mathrm{~N} / \mathrm{A}$ \\
\hline UE-5n & 229959 & 215315 & 948.5 & 514.2 & 215.4 \\
\hline U-9 ITS UE-U-29 \#2 & 265635 & 208210 & 1293 & 479.1 & $\mathrm{~N} / \mathrm{A}$ \\
\hline RNM \#1 & 230375 & 214832 & 955.8 & 396.8 & N/A \\
\hline U-9 ITS UE-U-29 \#1 & 265669 & 208369 & 1295 & 380.4 & N/A \\
\hline UE-4ai & 259911 & 204625 & 1273 & 356.6 & N/A \\
\hline RNM \#2S & 230185 & 214826 & 954.9 & 352.3 & 221.1 \\
\hline Marble \#3 & 275263 & 205700 & N/A & 298.1 & 145.4 \\
\hline RNM \#2 & 230204 & 214911 & 954.6 & 285.0 & N/A \\
\hline U-15k Test Hole & 275261 & 206489 & 1575 & 261.2 & N/A \\
\hline UE-15g & 274628 & 206558 & 1528 & 199.6 & N/A \\
\hline UE-15f & 274598 & 206626 & 1528 & 199.0 & N/A \\
\hline Test Hole \#1 & 256029 & 211531 & 1261 & 198.1 & N/A \\
\hline UE-2a & 264443 & 203444 & N/A & 190.8 & N/A \\
\hline UE-15h & 274652 & 206559 & 1528 & 184.7 & N/A \\
\hline Test Hole \#5 & 256638 & 212141 & 1284 & 153.6 & N/A \\
\hline Jangle Test Hole \#A4 & 268590 & 207386 & N/A & 152.4 & N/A \\
\hline Marble \#1 & 275074 & 205841 & N/A & 115.2 & N/A \\
\hline Marble \#2 & 275440 & 205998 & N/A & 83.5 & N/A \\
\hline Test Hole \#6 & 255724 & 212141 & 1265 & 158.5 & N/A \\
\hline U-9 ITS UE-U-22 & 264822 & 208239 & 1287 & 553.8 & N/A \\
\hline $\mathrm{UE}-11 \mathrm{a}$ & 236870 & 215884 & 1081 & 426.7 & 343.8 \\
\hline$U E-2 a b$ & 266090 & 203149 & 1345 & 387.1 & N/A \\
\hline $\mathrm{UE}-5 \mathrm{f}$ & 235458 & 216683 & 1006 & 335.3 & 272.2 \\
\hline Jangle Test Hole \#A2 & 267188 & 205374 & $\mathrm{~N} / \mathrm{A}$ & 54.0 & N/A \\
\hline$U E-3 d$ & 252888 & 209317 & $\mathrm{~N} / \mathrm{A}$ & 36.6 & N/A \\
\hline Test Well D & 258044 & 205009 & 1266 & 594.4 & 525.1 \\
\hline
\end{tabular}

wells in which a saturated interval was encountered, temperature, electrical conductivity, and $\mathrm{pH}$ logs were conducted to determine the presence of vertical fluid flow. A caliper log was conducted in wells where casing damage, or constrictions in the open borehole, was suspected. 


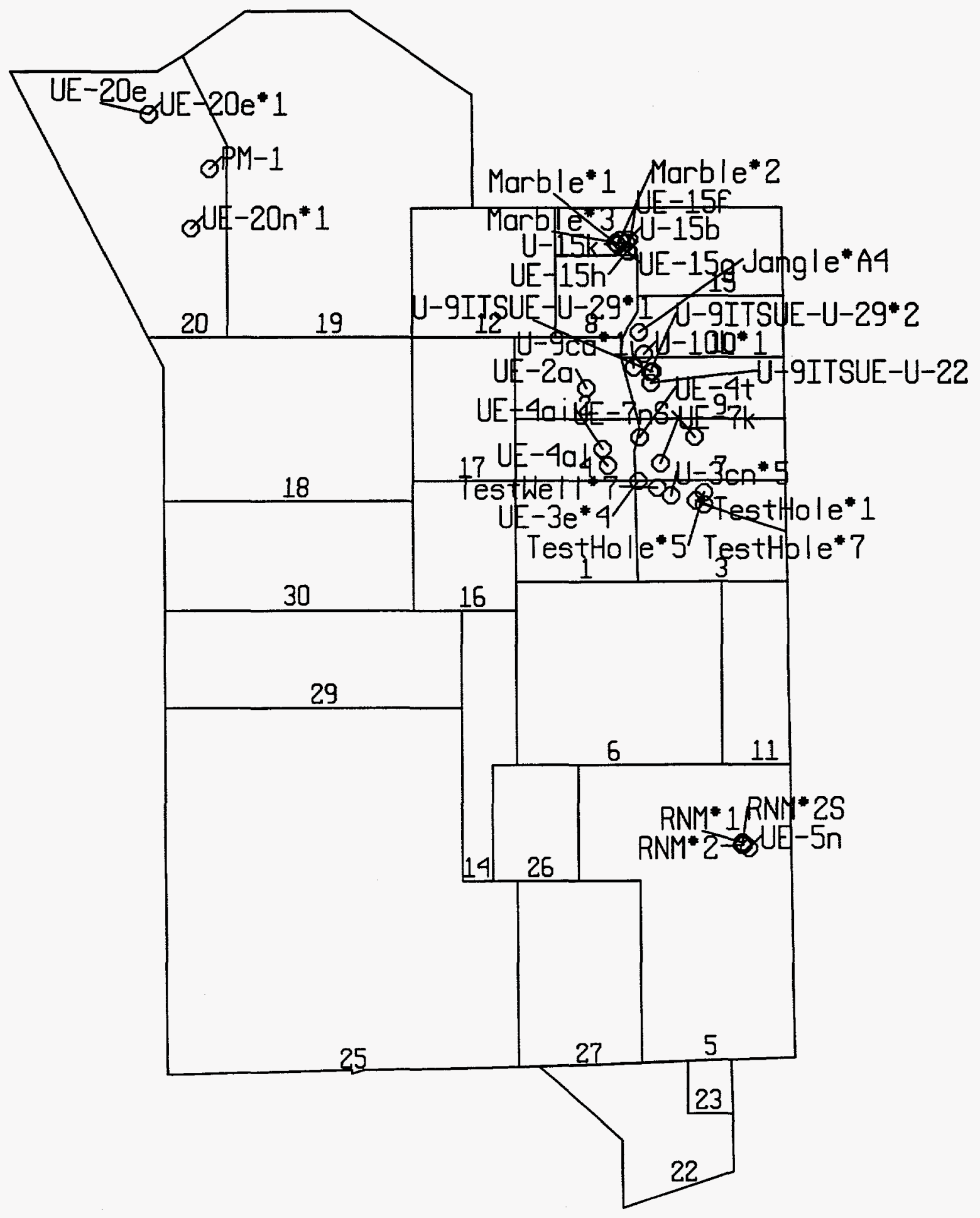

Figure 5. Existing wells located within $1000 \mathrm{~m}$ of tests conducted within $25 \mathrm{~m}$ below the water table at the NTS. 
In the following sections of this report, the well construction and completion, current condition, and location relative to nearby testing (within $50 \mathrm{~m}$ or below the water table) of the existing wells at the NTS are described. Recommendations are also made as to the suitability of individual wells for recompletion as groundwater monitoring locations or for plugging and abandonment. Lithologic symbols and stratigraphic nomenclature used in well construction diagrams and lithologic cross sections are given in Appendix C and D, respectively.

\section{PM-1}

One underground nuclear test (U-20ab) is located within one kilometer (1000 meters) of well PM-1 (Figure 6). Potentiometric data from this area (Winograd and Thordarson, 1975) indicate the general direction of groundwater flow in this area to be from the northeast toward the southwest. The underground test conducted at U-20ab was detonated approximately $40 \mathrm{~m}$ below the water table.

\section{Well Construction}

Well PM-1 (Figure 7) was drilled as an exploratory well in 1963, to a total depth of 2395.1 $\mathrm{m}$. The well was completed with 27.3-cm-diameter casing set at $2299.1 \mathrm{~m}$, with the annular space between the casing and the borehole cemented to the surface. Land surface elevation at the well site is $1998.8 \mathrm{~m}$ MSL. Open borehole, $24.3 \mathrm{~cm}$ in diameter, extends below the bottom of the casing to total depth.

In July 1994, a site visit was conducted to determine the condition of the wellhead. The wellhead at PM-1 consists of the 27.3-cm-diameter casing extending approximately $10 \mathrm{~cm}$ above ground level, with a 4-cm-thick flange welded to the top of the casing. This casing is covered with a flat metal lid, which is secured to the flange with short sections of welding rod.

The open borehole portion of the well (2299.1 to $2395.1 \mathrm{~m}$ ) penetrates a single hydrologic horizon. Well PM-1 has been sampled as part of the NTS groundwater monitoring network (Glines et al., 1994). Analysis results indicate a tritium concentration in the fluid within the well to be approximately $200 \mathrm{pCi} / \mathrm{L}$ (SDWA standard $=20,000 \mathrm{pCi} / \mathrm{L}$ ). However, there is no record of well development following completion and the slightly elevated tritium levels observed in samples from the well may not be representative of formation fluids produced by the open section of the borehole.

In August 1994, DRI personnel conducted a temperature/electrical conductivity/pH log of the well from the surface of the fluid level within the well to a depth of $931.4 \mathrm{~m}$. Fluid level within the well was measured at $638.6 \mathrm{~m}$ below land surface. Temperature, electrical conductivity and $\mathrm{pH}$ profiles do not indicate fluid movement over the logged interval. Logging of the well below the depth of $1067.4 \mathrm{~m}$ was not possible due to the limited length of DRI's wellbore logging tool (approximately $1150 \mathrm{~m}$ ).

\section{Discussion/Recommendations}

From construction of the well, it appears that PM-1 does not pose a threat from cross-aquifer contamination. The underground test conducted at $\mathrm{U}-20 \mathrm{ab}$ is located $0.856 \mathrm{~km}$ 


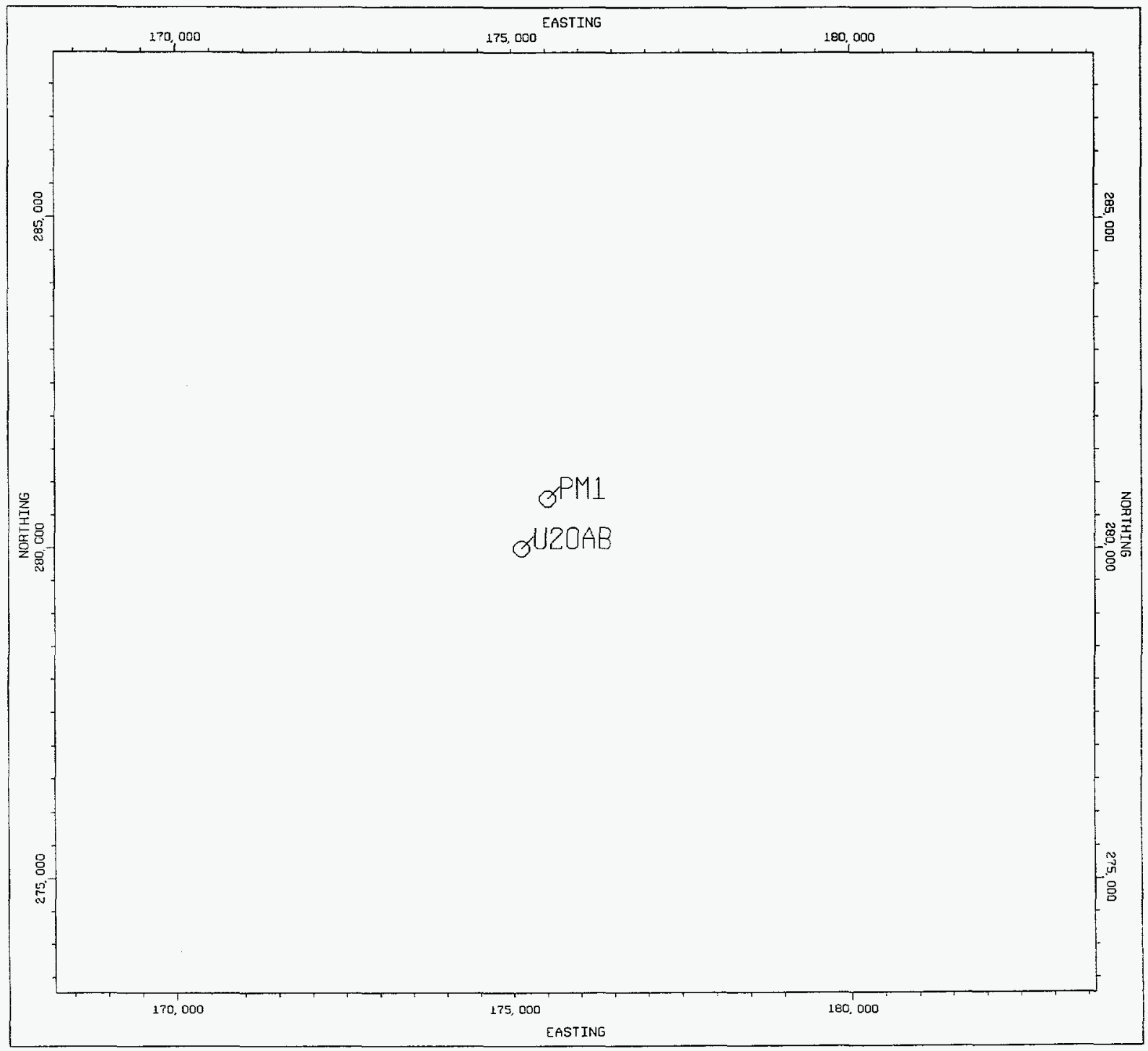

Figure 6. Map showing relative location of PM-1 and U-20ab. 


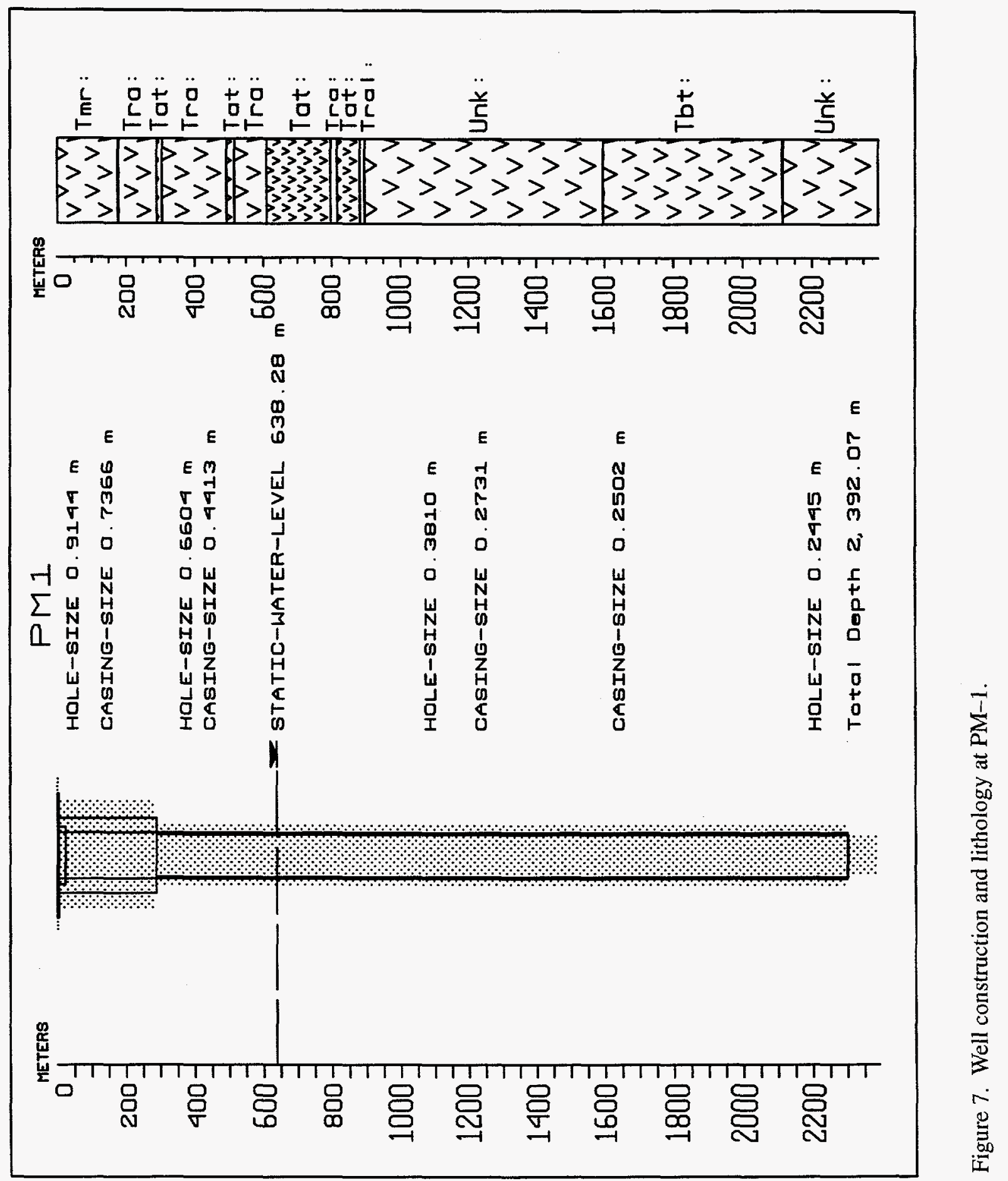


downgradient from well PM-1. Although there do not appear to be any underground tests conducted near or below the water table located within one kilometer upgradient of PM-1, the well would make a good groundwater monitoring location for two primary reasons: first, PM-1 is one of the deepest wells at the NTS, and as such would provide access to deep groundwater unaffected by testing, providing baseline data for groundwater quality underneath Pahute Mesa, and second, PM-1 is completed in a single hydrologic interval with large-diameter casing cemented to the surface.

The wellhead at PM-1 consists of only approximately $10 \mathrm{~cm}$ of the 27.3 -cm-diameter casing extending above the ground, with an unlocked flat metal lid. Located on Pahute Mesa at an elevation of almost $2000 \mathrm{~m}$ MSL, PM-1 regularly receives up to $50 \mathrm{~cm}$, or more, of snow accumulation. This poses a significant possible source for the introduction of contamination into the well.

The presence of the 27.3-cm-diameter casing in PM-1 greatly simplifies the recompletion effort required to produce a viable groundwater quality monitoring location. With the casing in the well, it should be possible to install a Moyno or small-diameter submersible pump and monitoring line within PM-1. Fluid produced from the well would be drawn from a single hydrologic horizon. This would permit purging and sampling of the well while monitoring fluid level drawdown.

If geophysical logging (cement bond log, temperature, EC, $\mathrm{pH}$ logs or thermal flowmeter log during displacement of water from the well, etc.) of the well indicated incomplete cement between the 27.3-cm-diameter casing and the wellbore, or leaks in the 27.3 -cm-diameter casing, it would be possible to complete the well with the pump and monitor lines placed inside a packer assembly located near the bottom of the cased interval where the cement is most likely to have filled the annular space between the casing and the wellbore.

To eliminate the possibility of contamination of the well by surface water, or other materials, the wellhead should be rehabilitated in a fashion as suggested by the U.S. Environmental Protection Agency (EPA) in its "Handbook of Suggested Practices for the Design and Installation of Ground-Water Monitoring Wells" (1991), pages 101-102, and Nevada Revised Statutes NAC Chapter 534. This rehabilitation consists primarily of the extension of the casing a minimum of $30 \mathrm{~cm}$ above ground level, installation of a concrete pad and bumper guards around the casing, installation of a watertight lockable cap, and any other measures required to assure the prevention of contamination of any portion of the well by surface waters or other materials.

\section{UE-20e and UE-20e \#1}

One underground nuclear test $(\mathrm{U}-20 \mathrm{e})$ is located within one kilometer of both wells UE-20e and UE-20e \#1 (Figure 8). The underground test conducted at U-20e was detonated approximately $605 \mathrm{~m}$ below the water table. Wells UE-20e and UE-20e \#1 are separated by a distance of approximately $30 \mathrm{~m}$. Both holes were drilled in 1964 as exploratory holes. 


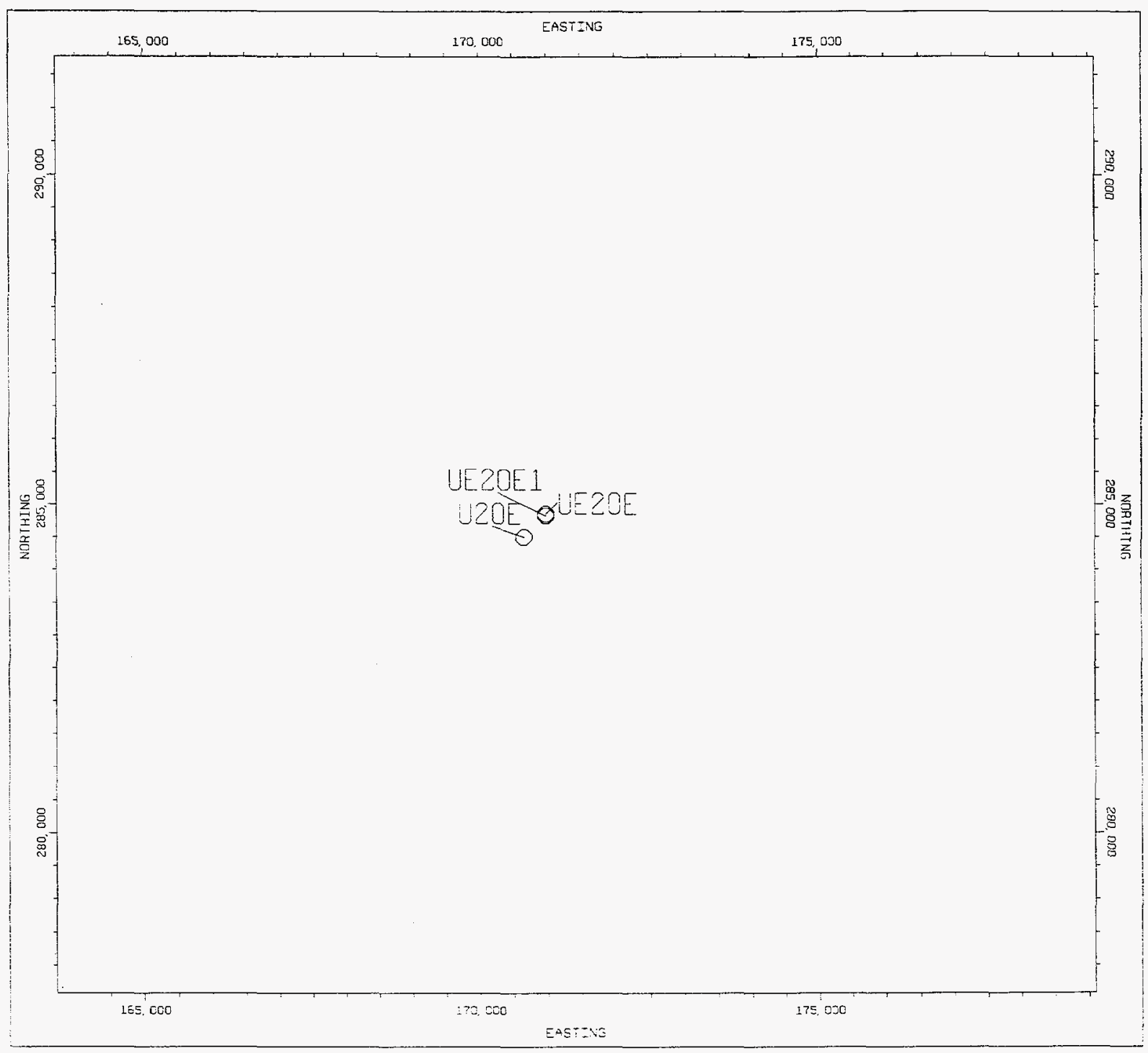

Figure 8. Map showing relative location of UE-20e \#1, UE-20e and U-20e. 
Potentiometric data from this area (Winograd and Thordarson, 1975) indicate the general direction of groundwater flow to be from the northeast towards the southwest, away from wells UE-20e and UE-20e \#1.

\section{Well Construction}

$U E-20 e$

Construction of UE-20e was abandoned at a total depth of $743.7 \mathrm{~m}$ due to hole problems. Land surface elevation at the well site is $1918.8 \mathrm{~m}$ MSL. The initial borehole at UE-20e (Figure 9) was drilled to a depth of $660.7 \mathrm{~m}$. Due to the loss of drill pipe in the hole, the hole was plugged back with cement to $341.64 \mathrm{~m}$, and a side-tracked hole was drilled. The side-tracked hole also had to be abandoned due to the loss of drill pipe. During construction of the side-tracked hole, 44.4-cm-diameter casing was set within the hole to $213.6 \mathrm{~m}$. The annular space between this casing and the wellbore was cemented to the surface. From the bottom of the casing, 31.1-cm-diameter borehole extends to total depth.

In February 1992, DRI, RSN, and Atlas Wireline Service (AWS) personnel preformed a total depth check in the well. A bridge was encountered at $358.4 \mathrm{~m}$, however, after breaking through the bridge, total depth was measured at $374.3 \mathrm{~m}$ (top of the lost drill pipe reported at $447.8 \mathrm{~m}$ ).

\section{$U E-20 e \# 1$}

Following abandonment of UE-20e, UE-20e \#1 (Figure 10) was drilled to a total depth of $1949.2 \mathrm{~m}$. Land surface elevation at the well site is $1918.8 \mathrm{~m}$ MSL. During construction, 34-cm-diameter casing was set within the hole to $1462.2 \mathrm{~m}$. The annular space between this casing and the wellbore was cemented to the surface. From the bottom of the casing, $25.1-\mathrm{cm}$ hole extends to total depth. Fluid level in the well following construction was reported at $553.8 \mathrm{~m}$. Following construction, pumping and straddle packer hydrologic tests were conducted. In 1968, a cement plug was placed within the wellbore from 1084.1 to $1158.2 \mathrm{~m}$. This plug was then drilled out to a depth of $1097.2 \mathrm{~m}$. As currently completed, the open portion of the borehole above the cement plug penetrates saturated intervals of the Tuffs and Lavas of Area 20.

In February 1992, DRI and RSN personnel visually detected a blockage in the hole. Depth to the blockage was measured at $18 \mathrm{~m}$ below land surface.

\section{Discussion/Recommendations}

The underground test site U-20e is located downgradient from wells UE-20e and UE-20e \#1. Due to their construction and lithology penetrated it appears that neither well poses a threat from cross-aquifer contamination.

Given its current construction, UE-20e \#1 could provide an upgradient monitoring location. After cleaning the well of obstructions to the top of the cement plug, a completion string of slotted casing could be gravel packed and cemented in place within the well. A small-diameter 


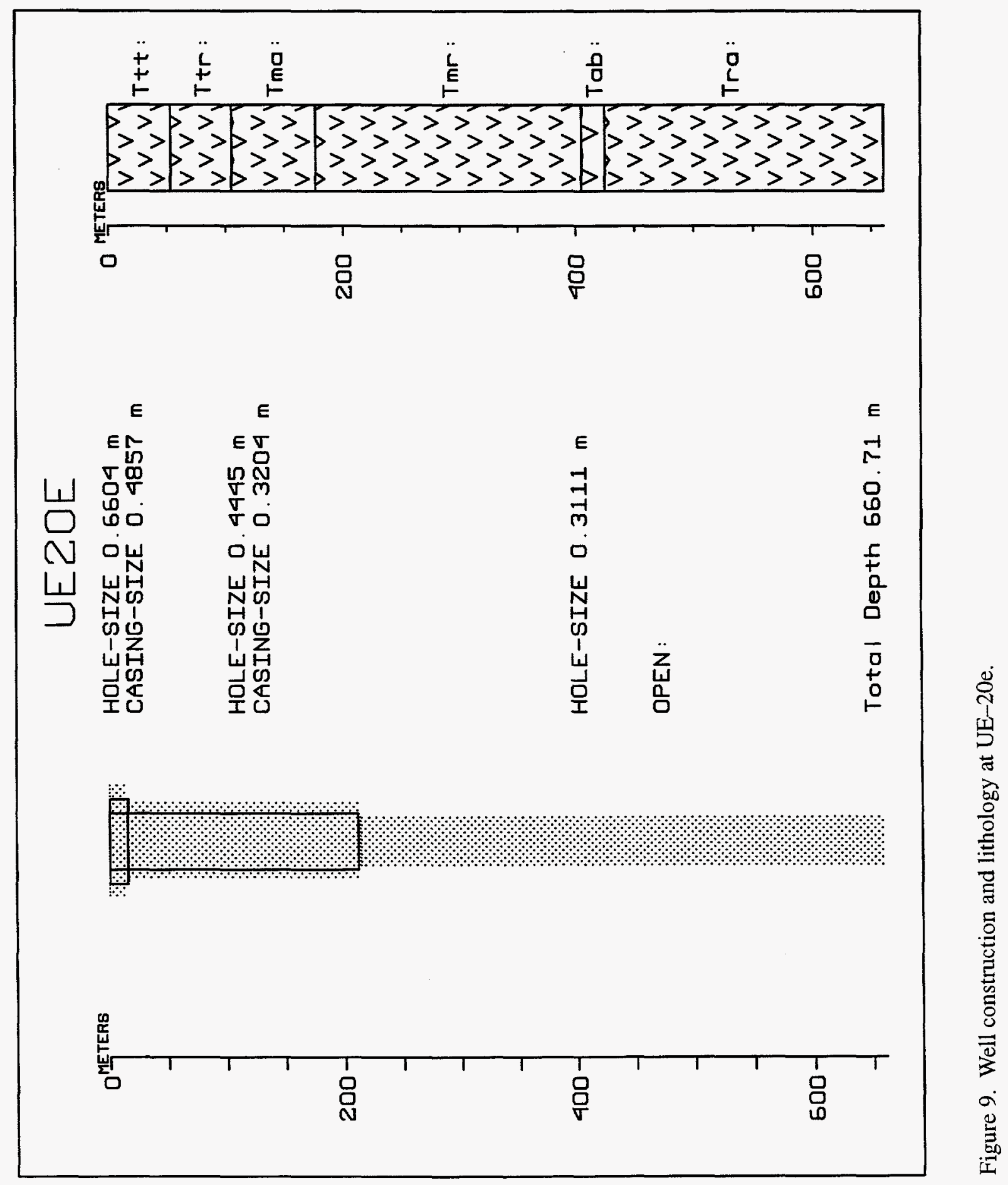




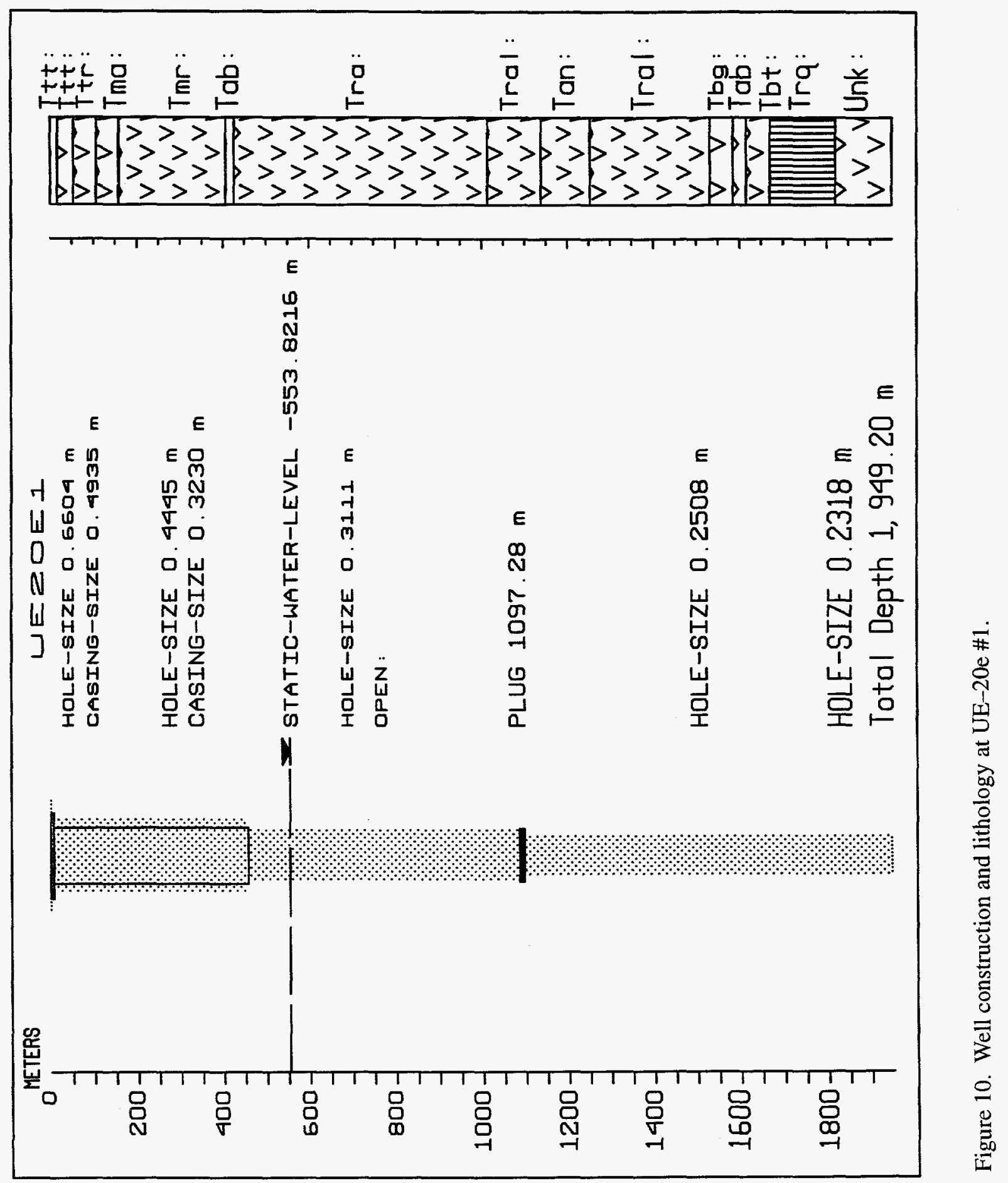


monitoring line and Moyno pump could then be placed within the well. With this type of completion, it would be possible to purge the well prior to sampling and to perform hydrologic testing of the completed interval.

Due to the close proximity of UE-20e to UE-20e \#1, and the difficulties produced by the loss of drill pipe within the well, UE-20e should be plugged and abandoned in accordance with current DOE NTS procedures and Nevada state regulations. This action would eliminate the possibility of contamination of the well by surface water, or other materials. Regardless of the action taken concerning these two wells, the wellheads at both locations should be rehabilitated in a fashion as suggested by the EPA in its "Handbook of Suggested Practices for the Design and Installation of Ground-Water Monitoring Wells," (1991), pages 101-102.

\section{U-9ca \#1}

Well U-9ca \#1 is located within one kilometer of the underground nuclear tests conducted near the water table in emplacement holes U-9cb and U-10af in Yucca Flat (Figure 11). The underground test conducted in U-9cb was detonated approximately $23 \mathrm{~m}$ below the water table and is located approximately $0.84 \mathrm{~km}$ northeast of well U-9ca \#1. The underground test conducted in U-10af was detonated approximately $43 \mathrm{~m}$ above the water table and is located approximately $0.8 \mathrm{~km}$ northwest of well U-9ca \#1. Potentiometric data from this area (Winograd and Thordarson, 1975) indicate the general direction of groundwater flow in this area to be from the northeast toward the southwest.

U-9ca \#1 (Figure 12) was drilled in 1964 as an instrument hole. Elevation of the land surface at the drill site is $1293.6 \mathrm{~m}$ MSL. During construction, 27.3-cm-diameter casing was set within the borehole to a depth of $548.6 \mathrm{~m}$. The annular space between the casing and the wellbore was cemented to the surface. Below the the casing, 25.1-cm-diameter hole was drilled to a total depth of $978.4 \mathrm{~m}$. Fluid level within the well is reported at $563.9 \mathrm{~m}$.

U-9ca \#1 penetrates approximately $55 \mathrm{~m}$ into Paleozoic carbonate units. Within the saturated interval above the Paleozoic carbonate section, Tertiary volcanic tuff units are present. These tuff units are zeolitic and most likely of low permeability. Following completion of the well, straddle packer hydrologic tests were conducted on selected units within the Tertiary interval. In 1979, a transducer and approximately $530 \mathrm{~m}$ of transducer cable were lost within the well. Due to the lost equipment, no attempt was made to perform a total depth/water-level check or conduct other geophysical logs.

\section{Discussion/Recommendations}

Although not directly downgradient from an underground test conducted near (within 25 $\mathrm{m}$ ) or below the water table, if properly recompleted U-9ca \#1 would serve as a viable Tertiary or Paleozoic groundwater quality monitoring location. If recompleted as a monitoring location in the Tertiary interval, it is unlikely significant water production would be possible to permit sampling of the well due to the apparent low transmissivity of the zeolitic tuff units within the 


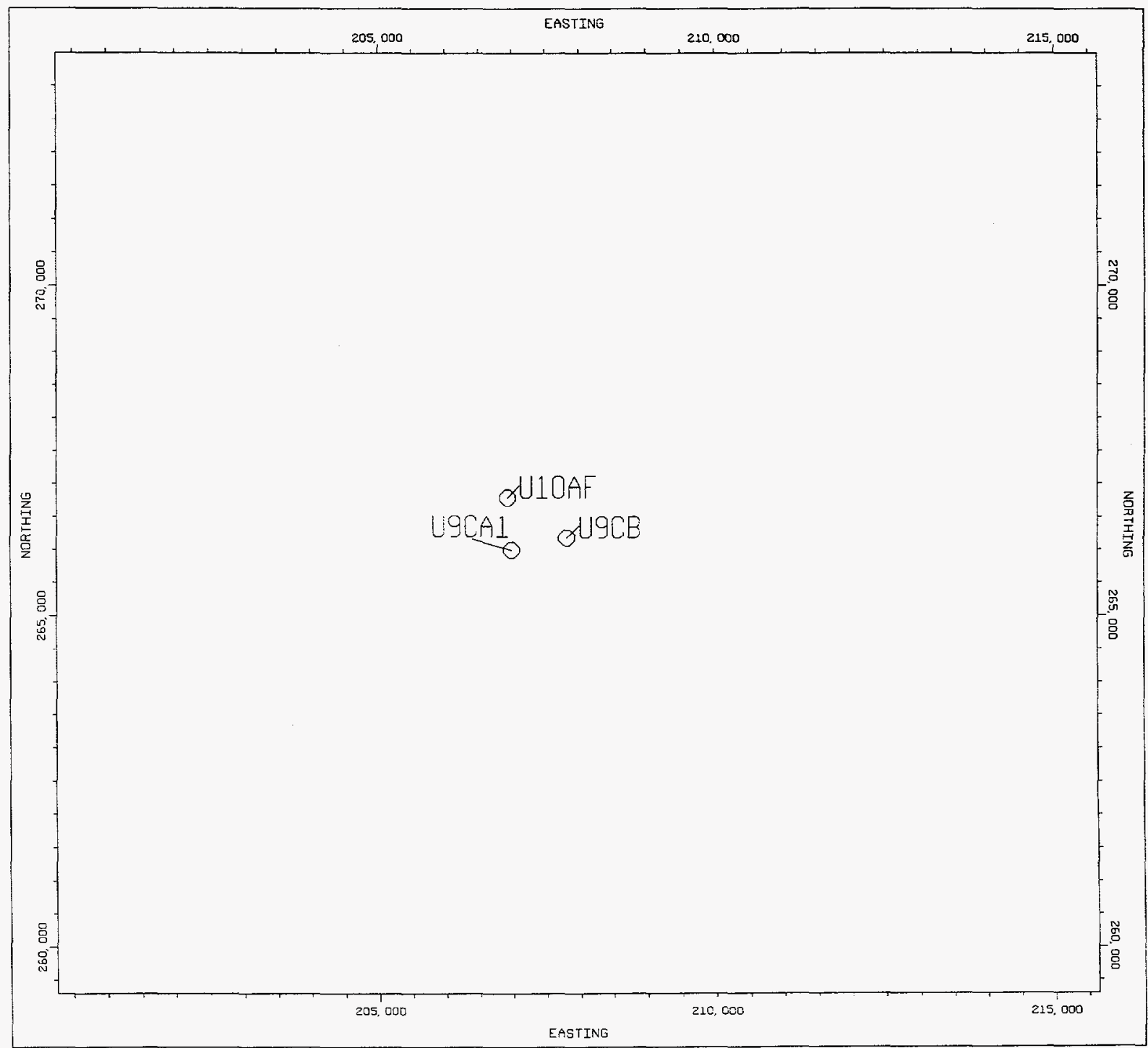

Figure 11. Map showing relative location of U-9ca \#1, U-10af and U-9cb. 
· I\#

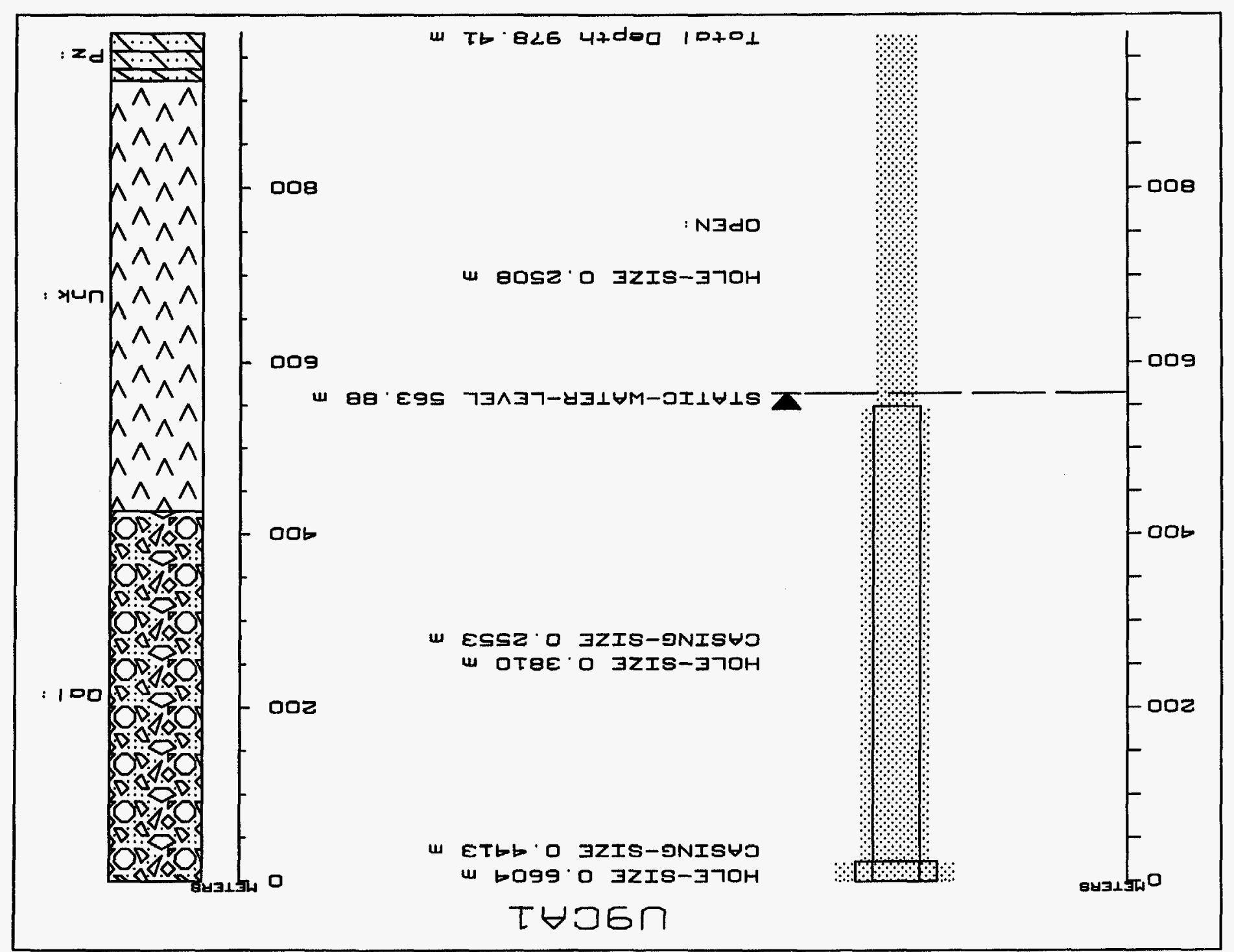


saturated zone. At a minimum, the cable and transducer should be removed from the well to permit sampling by bailer. This well would be an ideal candidate for recompletion by deepening the hole to produce a Paleozoic carbonate aquifer monitoring location. Following deepening of the borehole, geophysical logs and hydrologic tests could be conducted to identify zones of interest. The well could then be completed with the installation of gravel pack and slotted casing, and the placement of a Moyno pump and monitoring line to facilitate purging of the well prior to sampling and water level monitoring. Until U-9ca \#1 can be recompleted, the wellhead at U-9ca\#1 should be rehabilitated to preclude contamination of the well by surface water or other materials.

\section{UE-7ns}

Two underground nuclear tests conducted near or below the water table (U-7t and $U-7 n$ ) are located within one kilometer of well UE-7ns (Figure 13). Potentiometric data (Winograd and Thordarson, 1975) indicate the general direction of groundwater flow in this area to be from the east to the west. The test conducted at $U-7 \mathrm{n}$ was detonated approximately $37 \mathrm{~m}$ above the water table and is located $172 \mathrm{~m}$ west of UE-7ns. The test conducted at U-7t was detonated approximately $18 \mathrm{~m}$ above the water table and is located $0.98 \mathrm{~km}$ southwest of UE-7ns.

\section{Well Construction}

UE-7ns was drilled as an exploratory hole in 1976 to a total depth of $671.3 \mathrm{~m}$ (Figure 14). Land surface elevation at the drill site is $1331.1 \mathrm{~m}$ MSL. The contact between Tertiary volcanic units and Paleozoic carbonate aquifer was penetrated by the borehole at a depth of $499.1 \mathrm{~m}$.

Following the completion of drilling, the well was completed with 19.4-cm-diameter casing set at $669.7 \mathrm{~m}$. This casing is slotted over the interval from 607.3 to $669.4 \mathrm{~m}$. The casing also contained an external casing packer at $518.3 \mathrm{~m}$. After the casing was placed within the well, the packer was inflated, isolating the annular space between the 19.4-cm-diameter casing and the wellbore, above and below the packer. Cement was then placed in the annular space above the packer to the surface. This completion provides a hydraulic seal between the Paleozoic carbonate aquifer and the Tertiary volcanic units penetrated by the wellbore.

UE-7ns has been extensively pumped, and sampled intermittently, since its completion. It is currently sampled as part of the NTS groundwater monitoring network. Sample results from 1994 indicate a tritium concentration within the well fluid of as high as approximately 3000 pCi/L (Buddemeier and Isherwood, 1985).

In June 1994, a site visit was conducted to determine the condition of the wellhead. The wellhead at UE-7ns consists of approximately $25 \mathrm{~cm}$ of 50.8 -cm-diameter surface casing extending above ground level. Inside the surface casing, the 19.4-cm-diameter casing extends approximately $40.6 \mathrm{~cm}$ above ground level. The well currently has two strings of 7.3-cm-diameter tubing set within the 19.4-cm-diameter casing to a depth of approximately $615.1 \mathrm{~m}$. These two tubing strings extend above the 19.4-cm-diameter casing approximately 15 


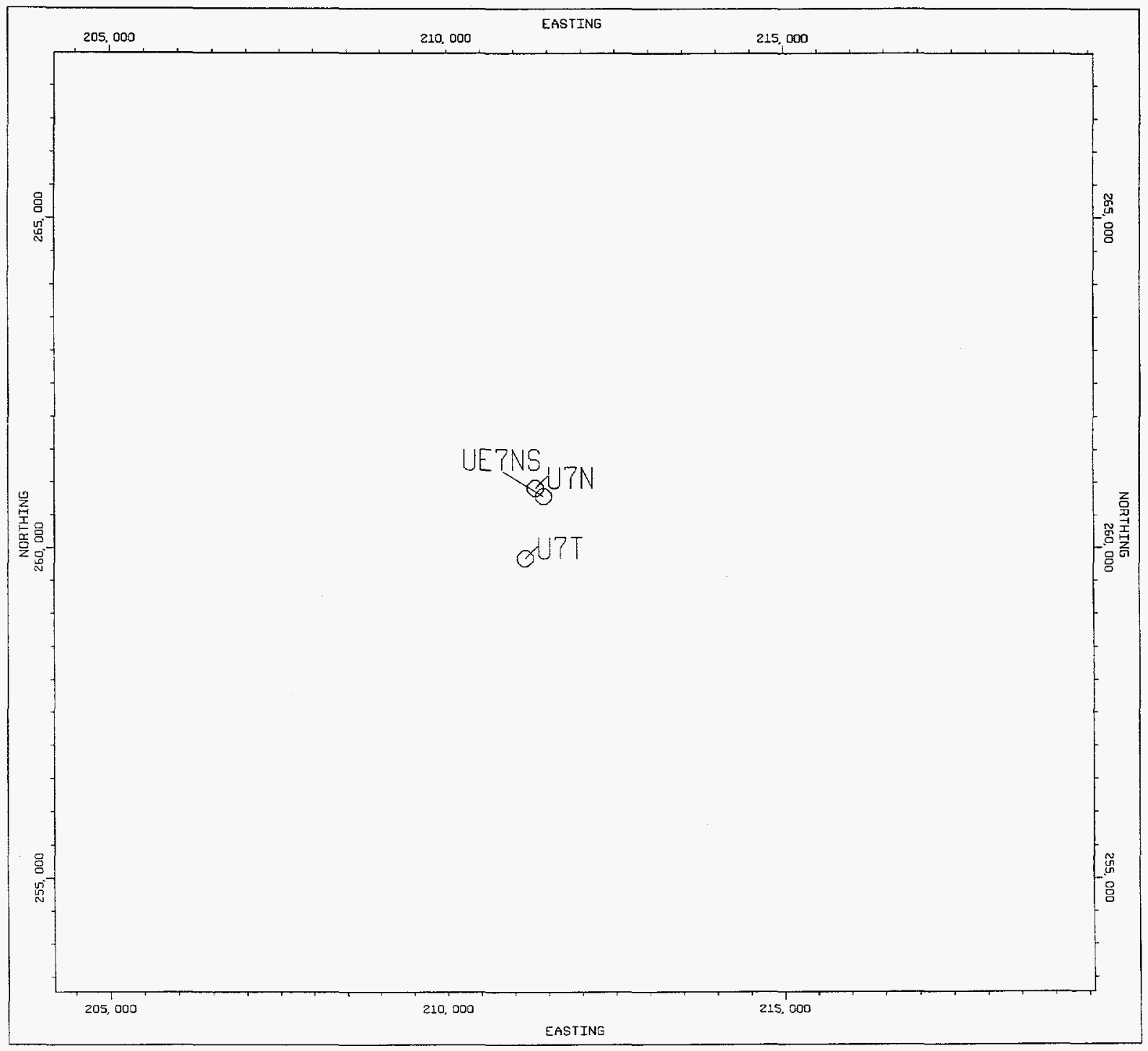

Figure 13. Map showing relative location of UE-7ns, U-7n and U-7t. 


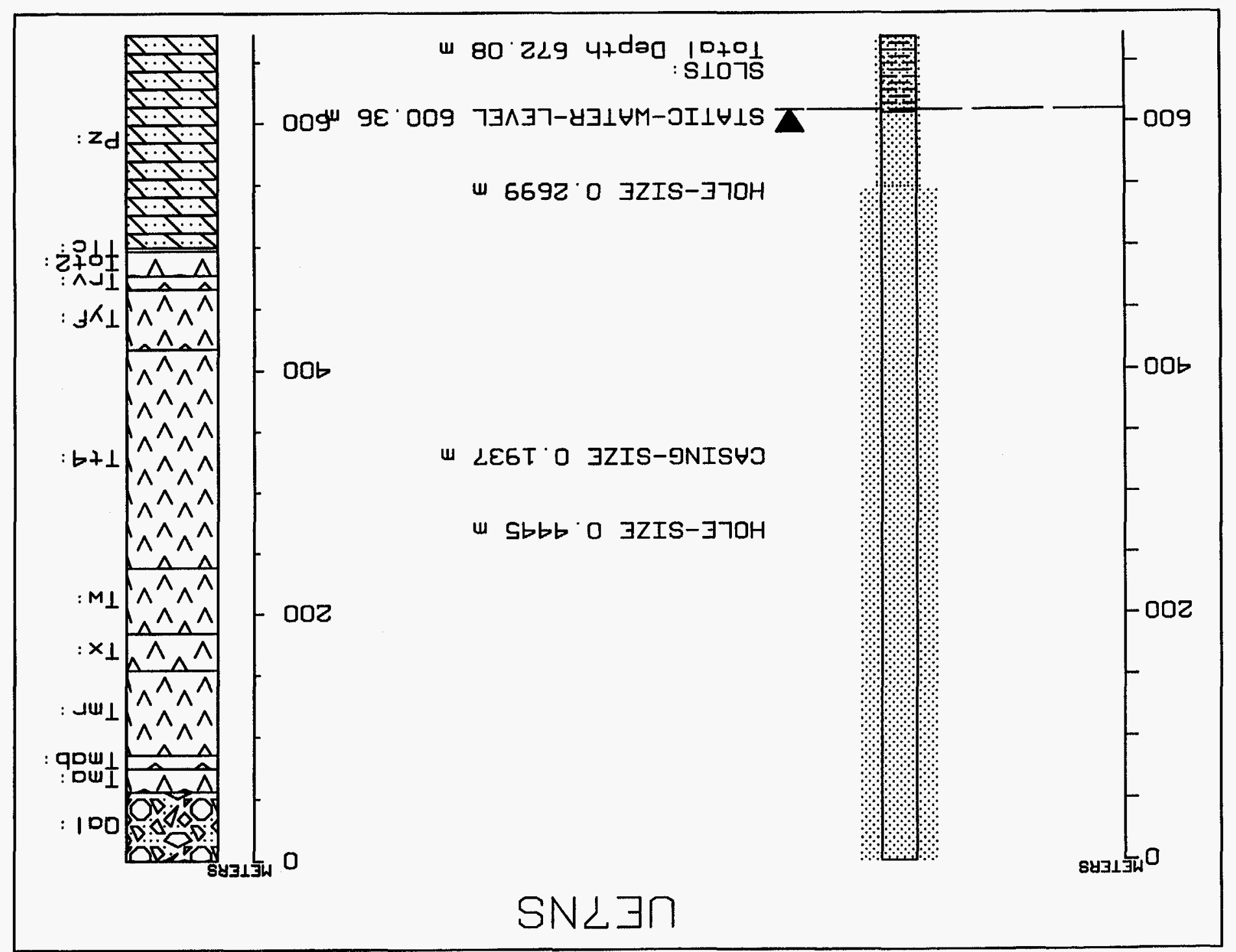


$\mathrm{cm}$. Both tubings strings are covered by a single hinged, flat, steel plate. The hinged plate is secured with a lock. In one of these tubing strings a transducer and an unknown amount of wireline is reported to have been lost.

In July 1994, DRI personnel conducted a temperature/electrical conductivity log of the open tubing string from fluid level $(600.4 \mathrm{~m})$ to near the bottom of the tubing string $(615.2 \mathrm{~m})$. No attempt was made to log below the bottom of the tubing due to the concern that the transducer and wireline lost in the other tubing string may have fallen down into the cased portion of the hole below the bottom of the two tubing strings. The temperature log did not indicate any fluid movement over the logged portion of the well.

\section{Discussion}

From an examination of the lithologic units penetrated and the construction of well UE-7ns, it appears that the well does not pose a threat from cross-aquifer contamination. The source of the slightly elevated tritium levels measured in fluid from the well is uncertain.

The current completion of well UE-7ns appears adequate to ensure groundwater quality samples collected from the well would be representative of fluids present in the Paleozoic carbonate section penetrated by the well. However, current completion allows for sampling by bailer only. Recompletion of well UE-7ns by removal of the two tubing strings and lost wireline and transducer, and the installation of a Moyno pump and monitor line, would greatly improve the quality of samples collected from the well at minimal cost.

To prevent contamination of the well by surface water, or other materials the wellhead should be rehabilitated in a fashion as suggested by the EPA in its "Handbook of Suggested Practices for the Design and Installation of Ground-Water Monitoring Wells," (1991), pages 101-102.

\section{UE-4ai and UE-4al}

Wells UE-4ai, and UE-4al have four underground nuclear tests (U-4ak, U-4i, U-4au, and U-4ar) conducted near (within $50 \mathrm{~m}$ ) or below the water table located within one kilometer of one, or both, of the wells (Figure 15). Potentiometric data from this area (Winograd and Thordarson, 1975) indicate the general direction of groundwater flow to be from the west towards the east. The tests conducted at U-4ak, U-4i, U-4au, and U-4ar were detonated $49 \mathrm{~m}$ above, $88 \mathrm{~m}$ below, $22 \mathrm{~m}$ above, and 11 above the water table respectively. All four tests are located southeast of well UE-4ai and northeast, east and southeast of well UE-4al.

Well Construction

$U E-4 a i$

UE-4ai was drilled as an exploratory hole in 1983 to a total depth of $356.6 \mathrm{~m}$ (Figure 16). Land surface elevation at the drill site is $1273.2 \mathrm{~m}$ MSL. During construction, 34-cm-diameter casing was cemented in the hole to a depth of $24.3 \mathrm{~m}$, and the annular space between the casing 


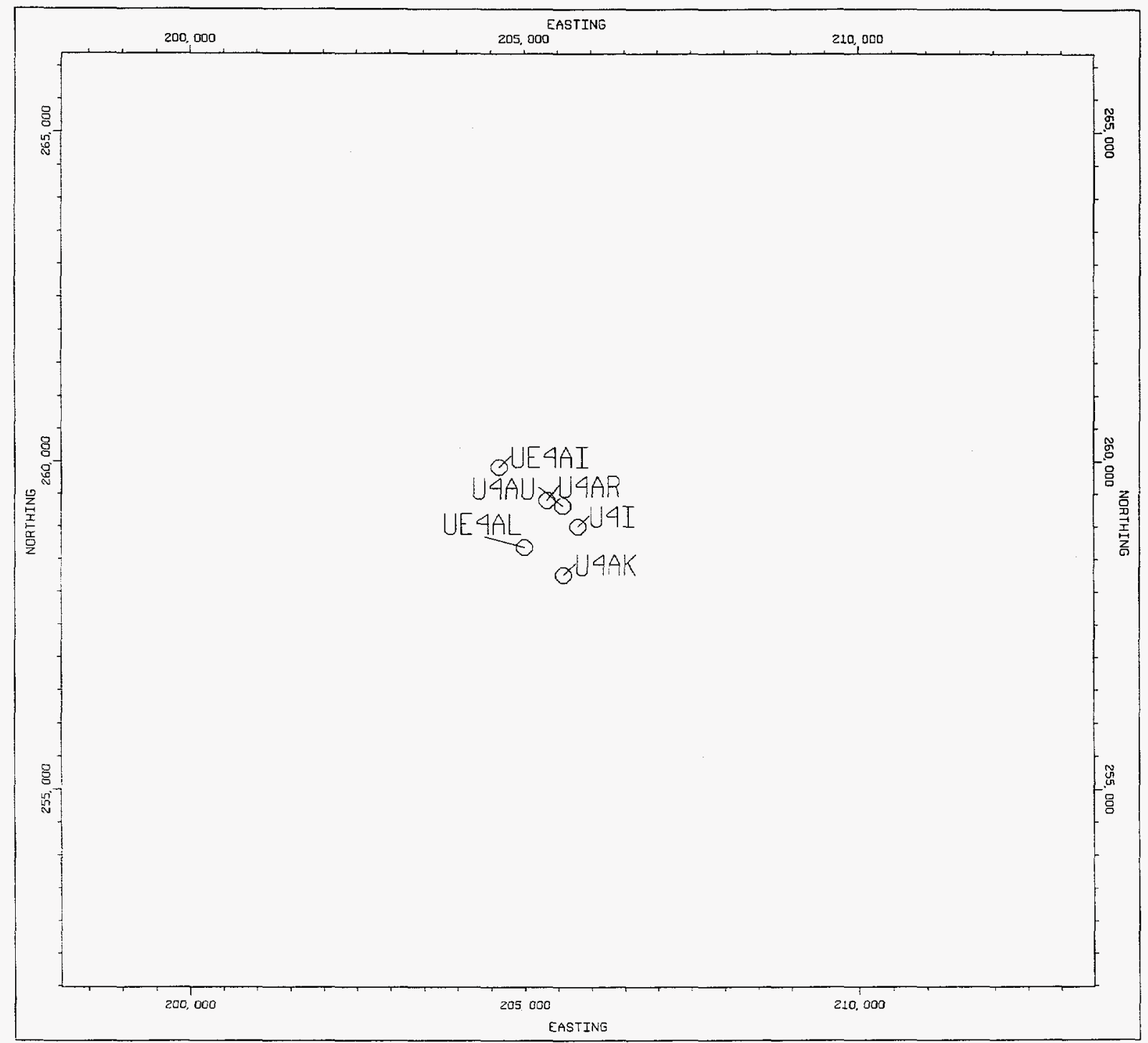

Figure 15. Map showing relative location of UE-4ai, UE-4al, U-4ak, U-4ar, U-4au and U-4i. 


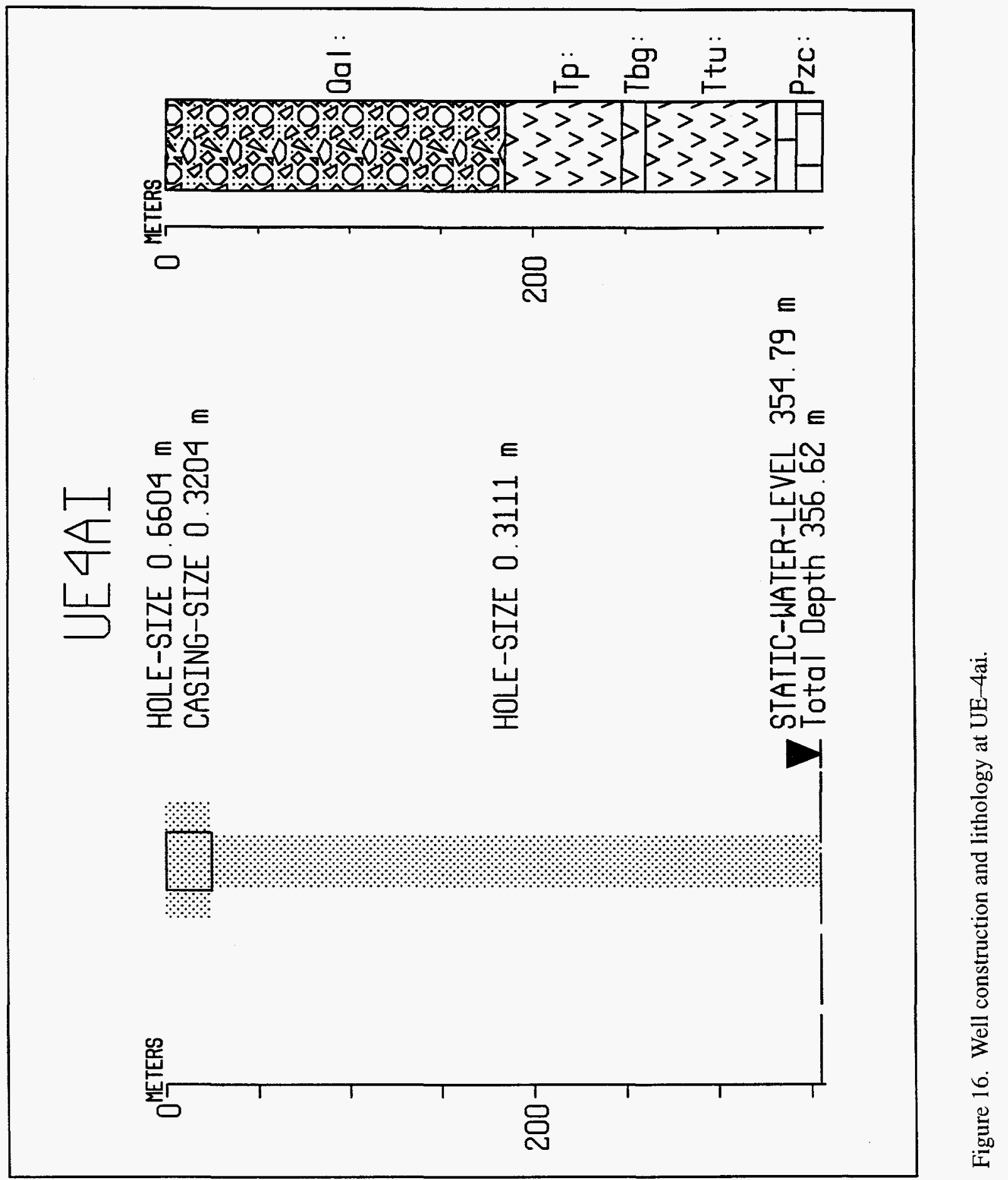


and the wellbore was cemented to the surface. Below the casing, 31.1-cm-diameter borehole extends to total depth. The well did not penetrate the water table (estimated elevation of water table in area approximately $354.8 \mathrm{~m}$ ).

In June 1994, a site visit was conducted by DRI personnel to determine the condition of the wellhead. The wellhead at UE-4ai consists of approximately $0.8 \mathrm{~m}$ of 32.4-cm-diameter casing extending above ground level. The casing is covered with a hinged, lockable lid, however, there was no lock.

In July 1994, DRI personnel conducted a total depth check within the well. Total depth was measured at $351.5 \mathrm{~m}$. Following completion of the total depth check, a lock was installed on the cap for the well. The lock is of the same type and key as the locks currently used for the NTS groundwater monitoring network and ER program wells.

$U E-4 a l$

UE-4al (Figure 17) was drilled in 1982 as an exploration well to a total depth of $666.6 \mathrm{~m}$. Land surface elevation at the drill site is $1266.5 \mathrm{~m} \mathrm{MSL}$. During construction, casing was placed within the well from the surface to $25.1 \mathrm{~m}$. The annular space between the casing and the borehole was cemented to the surface. Below the casing, 31.1-cm-diameter hole was drilled to total depth.

The well penetrated alluvium to a depth of $480.5 \mathrm{~m}$. The contact between Tertiary and Paleozoic units within the well is at $509.1 \mathrm{~m}$. Only a relatively thin section of Tertiary units (approximately $29 \mathrm{~m}$ ) was encountered by the wellbore.

Following the completion of UE-4al, the well was stemmed with sand from total depth to the surface. Although not measured in the well, the water table near well UE-4al is estimated to be at approximately $737 \mathrm{~m}$ MSL, within the Paleozoic units penetrated by the well.

In June 1994, a site visit was conducted by DRI personnel to determine the condition of the wellhead. The wellhead at UE-4al consists of approximately $3 \mathrm{~cm}$ of 32.4-cm-diameter casing extending above ground level. The casing is capped with a round steel plate welded to the casing.

\section{Discussion/Recommendations}

From an examination of the areal distribution, the construction of the wells, the lithologic units penetrated, and the depth of burial for the underground tests, neither well UE-4ai nor UE-4al would serve as suitable downgradient monitoring locations. However, these wells are located in proximity to several underground tests conducted in the unsaturated alluvium and Tertiary volcanic intervals which, although conducted $25 \mathrm{~m}$ above the water table, may have impacted the groundwater.

Well UE-4ai does not penetrate the water table, and would require significant deepening to be recompleted as a groundwater monitoring location, although this may be desirable at some future date. 


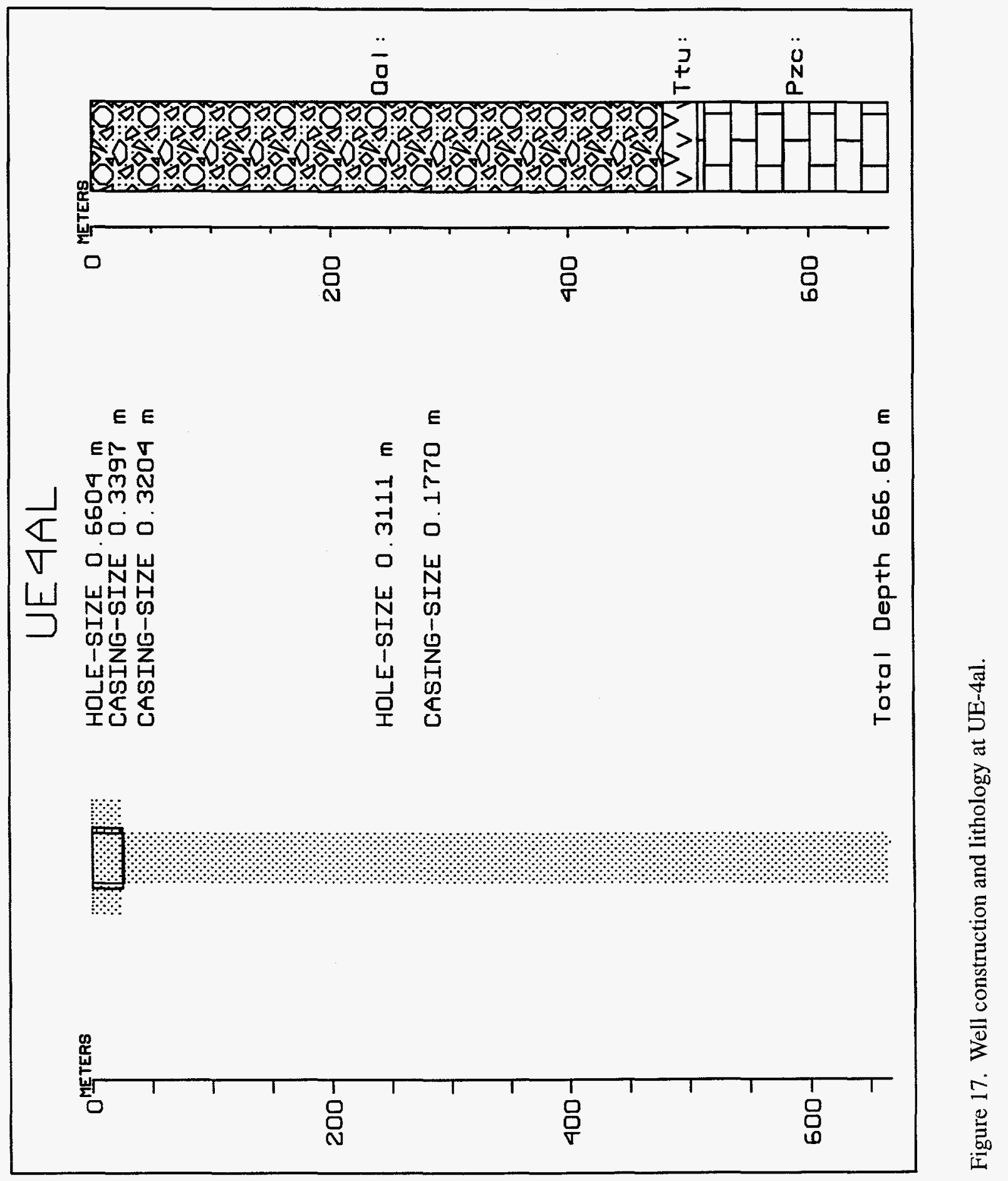


Approximately $137 \mathrm{~m}$ of saturated Paleozoic carbonate aquifer was penetrated by the wellbore in UE-4al. UE-4al was stemmed with sand from total depth to the surface. The assumed high permeability of the sand used to stem the hole may provide an avenue for flow between more permeable intervals within the wellbore; however, since the estimated static water level in the well would be within the Paleozoic carbonate interval, cross-aquifer flow should not present a problem in the well. If not destroyed by nearby testing events, it may be desirable to clean the sand from the well to produce a serviceable groundwater monitoring location in the carbonate aquifer. Additionally, this well, and many others at the NTS, may require removal of the stemming material (sand) to total depth for it to be properly abandoned.

Regardless of the actions taken to recomplete or plug and abandon these wells, the wellheads at wells UE-4ai and UE-4al should be rehabilitated to prevent contamination by surface water, or other materials.

\section{UE-7k}

Four underground nuclear tests conducted near or below the water table (U-7z, U-7e, U-7ac, and U-3dh) are located within one kilometer of well UE-7k (Figure 18). Potentiometric data (Winograd and Thordarson, 1975) indicate the general direction of groundwater flow in this area to be from the north to the south. The underground tests conducted at U-7z, U-7e, U-7ac, and U-3dh were detonated at $39 \mathrm{~m}$ below, $21 \mathrm{~m}$ below, $134 \mathrm{~m}$ below, and $18 \mathrm{~m}$ above the water table, respectively. Only the test conducted at U-7e lies to the north of well UE- $7 \mathrm{k}$. The emplacement hole U-7z is located west of UE-7k. The other two tests (U-7ac and U-3dh) conducted near or below the water table within $1000 \mathrm{~m}$ of well UE-7k are located south of UE-7k.

\section{Well Construction}

UE-7k was drilled as an exploration hole in 1981 to a total depth of $776.6 \mathrm{~m}$ (Figure 19). Land surface elevation at the drill site is $1257.7 \mathrm{~m} \mathrm{MSL}$. During construction, 34-cm-diameter casing was set within the hole to a depth of $22.6 \mathrm{~m}$. The annular space between this casing and the wellbore was cemented to the surface. Below the casing, 22.2-cm-diameter borehole was drilled to total depth.

The well penetrated the contact between Tertiary volcanic units and the Paleozoic carbonate aquifer at a depth of $738.2 \mathrm{~m}$. Although a static water level was not recorded for the well following completion of drilling, the water table in the area of the well is estimated to be at a depth of approximately $528 \mathrm{~m}$.

In June 1994, DRI personnel conducted a site visit to determine the condition of the wellhead. The wellhead at UE-7k consists of approximately $6.3 \mathrm{~cm}$ of the 34-cm-diameter casing extending above ground level. The casing is capped with a hinged, lockable, steel plate, however, there was no lock.

In July 1994, DRI personnel conducted a total depth check within the well. Total depth was measured at $93.4 \mathrm{~m}$ below land surface. Following completion of the total depth check, a lock 


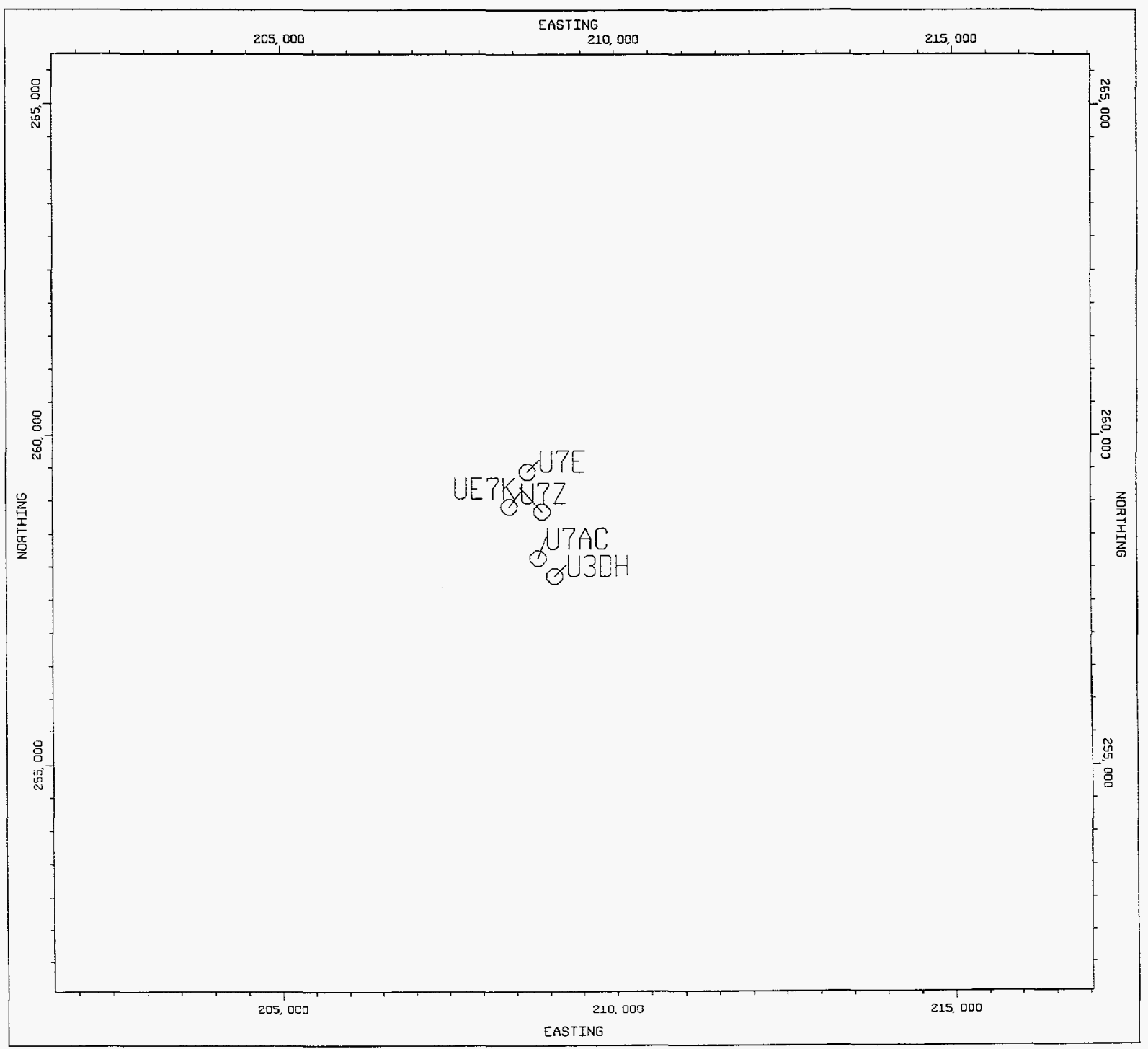

Figure 18. Map showing relative location of U-7e, U-7z, UE-7k, U-7ac and U-3dh. 


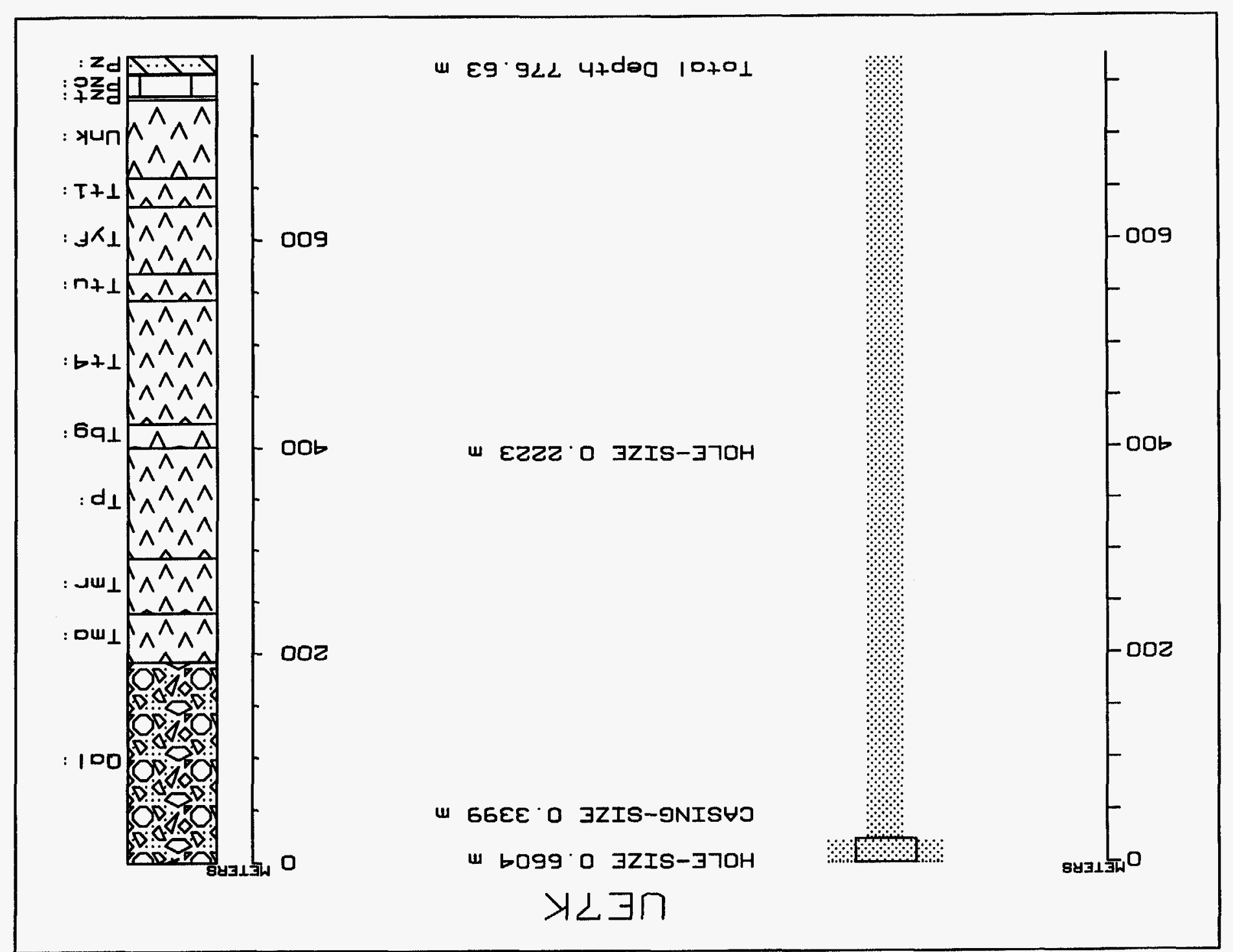


was installed on the cap for the well. The lock is of the same type and key as the locks currently used for the NTS groundwater monitoring network and ER program wells.

\section{Discussion/Recommendations}

UE-7 $\mathrm{k}$ penetrates saturated intervals of both Tertiary volcanics and the Paleozoic carbonate aquifer (Figure 19). To preclude the possibility of cross-aquifer flow within the wellbore, the well should be either recompleted as a monitoring well or plugged and abandoned.

$\mathrm{UE}-7 \mathrm{k}$ is located in an area where numerous underground nuclear tests have been conducted. The fairly large-diameter casing $(34 \mathrm{~cm})$ set in the well permits recompletion possibilities which would not be possible in a hole with smaller-diameter casing cemented within the wellbore. After cleaning the well of obstructions, a completion string consisting of slotted casing could be gravel packed and cemented in place within the well. Moyno pump tubing and a small-diameter monitoring line placed in the recompleted well would permit water level measurement to be obtained during pumping. With this type of completion, it would be possible to purge the well prior to sampling and to perform hydrologic testing of the completed interval.

Regardless of the future actions taken to recomplete or plug and abandon this well, the wellhead at UE- $7 \mathrm{k}$ should be rehabilitated to prevent contamination of the well by surface water, or other materials, until a decision on the fate of the well is made.

\section{$\mathrm{UE}-3 \mathrm{e} \# 4$}

Seven underground nuclear tests (U-3kz, U-7aq, U-3la, U-7bu, U-3gg, U-7an, and U-3mt) have been conducted near (within $50 \mathrm{~m}$ ) or below the water table within one kilometer of well UE-3e \#4 (Figure 20). Potentiometric data (Winograd and Thordarson, 1975) indicate the general direction of groundwater flow in this area to be from the north to the south.

UE-3e \#4 (Figure 21) was drilled in 1989 for the DOE Hydrologic Resources Management Program (HRMP) to a total depth of $701.0 \mathrm{~m}$. Land surface elevation at the well site is 1244.3 $\mathrm{m}$ MSL. During drilling of the well, 34-cm-diameter casing was set to a depth of $439.5 \mathrm{~m}$. The annular space between the casing and the wellbore was cemented to the surface. Following the completion of drilling, three 7.3-cm-diameter piezometer tubes were gravel packed and cemented within the well. These piezometer tubes contained slots over the following intervals: tube 1,655.3 - 658.7 m; tube 2,575.2 - 581.6 m; and tube 3,493.5-499.9 m. All three piezometer tubes were developed by swabbing following completion of the well.

Following construction of the borehole, but prior to installation of the piezometer tubes, fluid level in the well was measured at $470.9 \mathrm{~m}$. Current fluid levels within the three piezometer tubes are approximately: tube $1,472.8 \mathrm{~m}$; tube $2,405.7 \mathrm{~m}$; and tube $3,333.8 \mathrm{~m}$.

All three piezometer tubes in UE-3e \#4 are completed within the Tertiary volcanic section. The uppermost interval is completed within nonwelded to densely welded ash-flow tuff units of the Tertiary volcanic aquifer. The two lower intervals are completed in zeolitized air-fall and bedded tuff units of the Tertiary confining unit. 


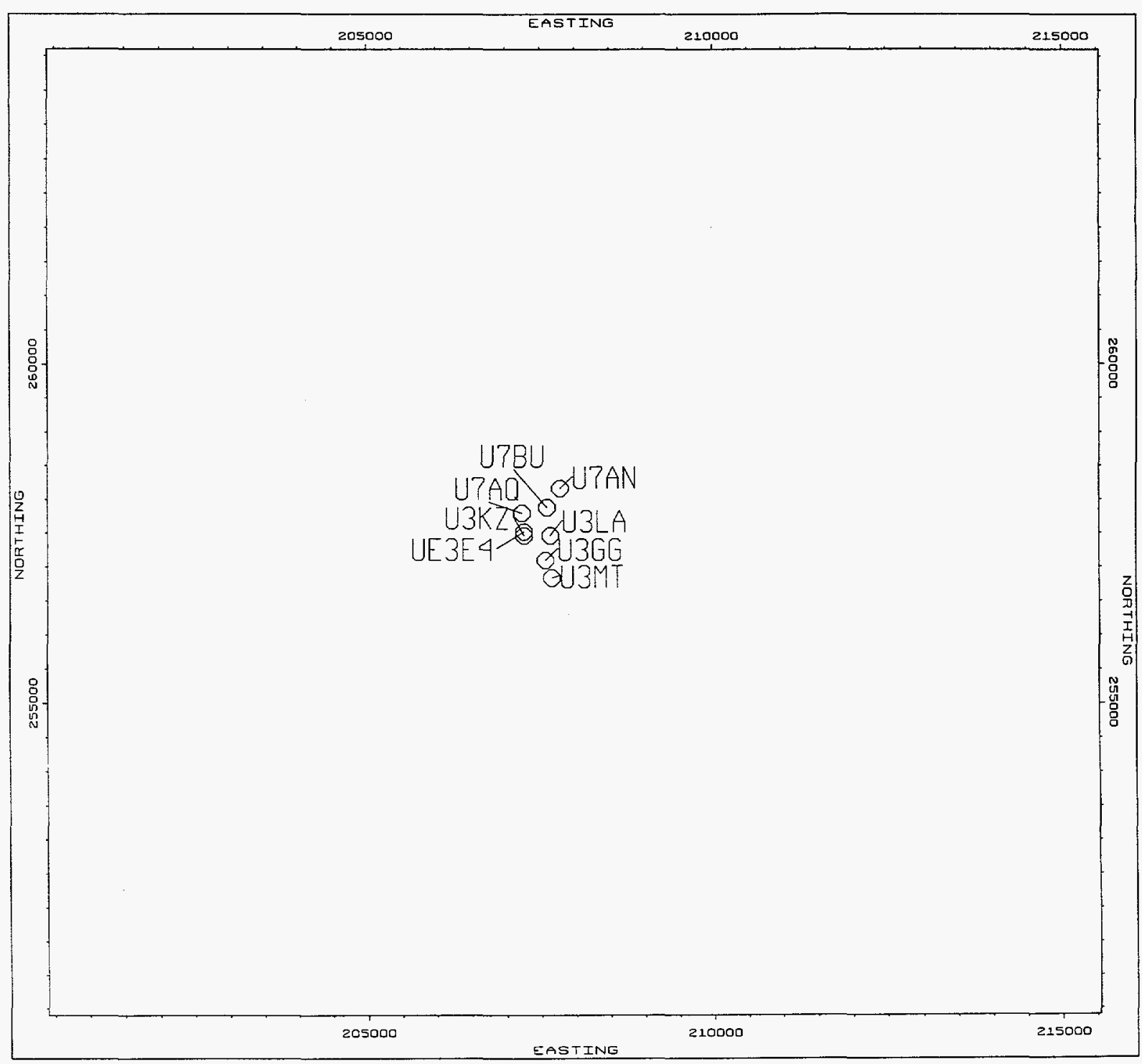

Figure 20. Map showing relative location of U-3mt, U-7an, U-7bu, U-7aq, U-3kz, U-3la, U-3gg and UE-3e \#4. 


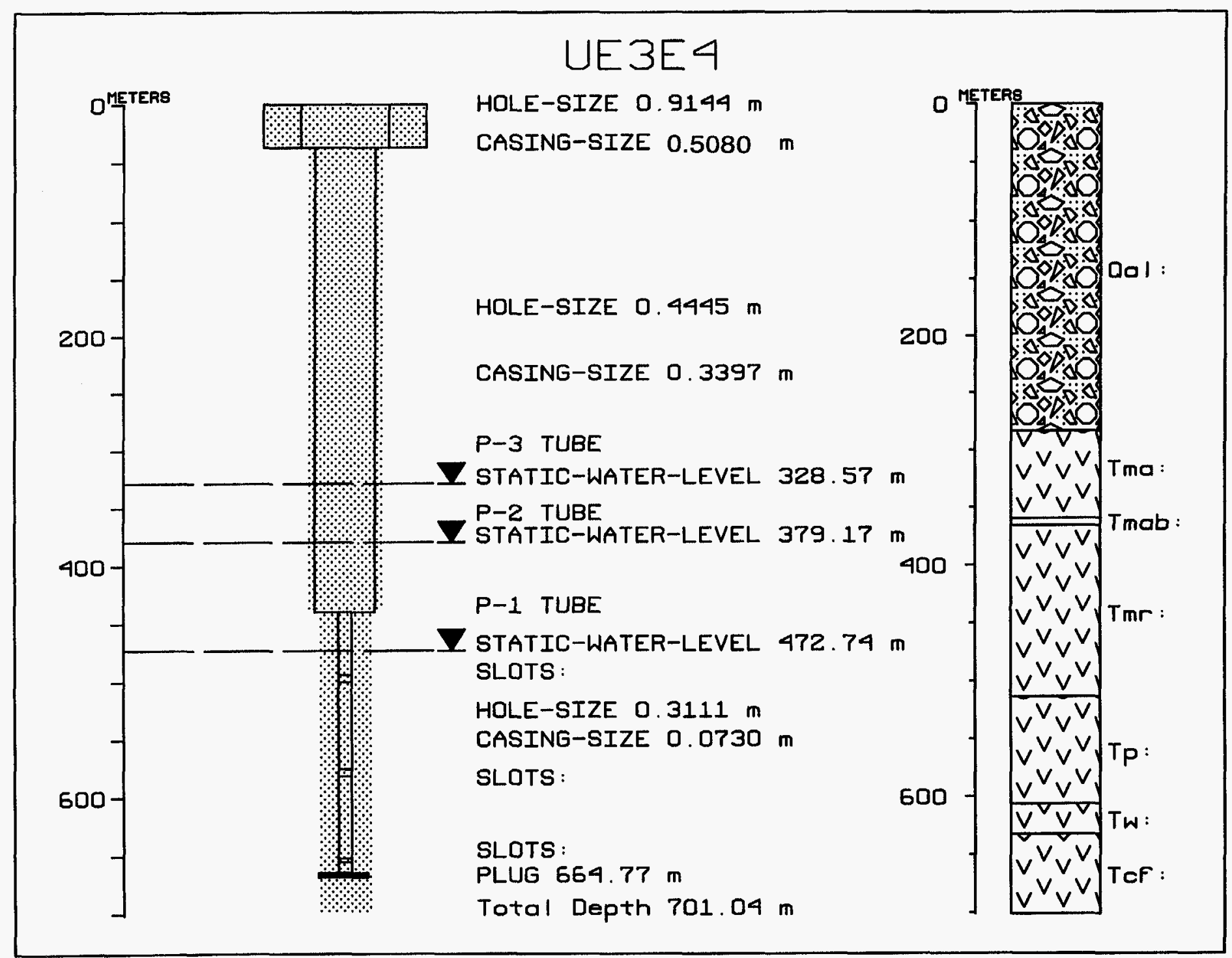

Figure 21. Well construction and lithology at UE-3e \#4. 
The drilling, completion, logging, testing and sampling history of UE-3e \#4 has been described in detail in "Interim Report of the Drilling History and Analysis for Nevada Test Site Hole Ue3e\#4," compiled and edited by Joseph Thompson (1992) of Los Alamos National Laboratory.

In June 1994, a site visit to UE-3e \#4 was conducted by DRI personnel to determine wellhead conditions. The wellhead consists of approximately $1 \mathrm{~m}$ of the 34-cm-diameter casing extending above ground surface. The tops of the three piezometer tubes are located inside and just below the top of the casing. The casing is covered with a flat, hinged, lockable lid. The lid is secured with a lock of the type and key currently used on HRMP groundwater monitoring and ER program wells at the NTS. At the time of the visit, USGS transducers on wirelines were being used to monitor fluid levels in two of the three tubes.

\section{Discussion/Recommendations}

As currently completed, UE-3e \#4 does not present an avenue for cross-aquifer flow. The well is located in an area were numerous underground tests have been conducted. Well UE-3e \#4 was drilled to investigate the high static water level and radionuclides detected during drilling of the emplacement hole U-3kz. Radionuclides detected in fluid samples from U-3kz and UE-3e \#4 are believed to originate from the underground test conducted at U-3aq (Thompson, 1991). If sampled on a regular basis this well could continue to provide valuable information on radionuclide transport and testing-induced hydrologic phenomena at the NTS.

Due to the relatively small diameter of the tubing strings in place within the well, sampling is currently limited to using a bailer. It is unlikely the two lower intervals, completed within low permeability zones, would produce sufficient fluids to be sampled by pumping. However, the upper interval, completed within more permeable nonwelded to densely welded ash-flow tuff units could be recompleted with the installation of a small-diameter Moyno pump string to facilitate purging of well fluid prior to sampling.

To prevent contamination of the well by surface water, or other materials, the wellhead at UE-3e \#4 should be rehabilitated.

\section{U-3cn \#5}

Two announced underground nuclear tests (U-3cn and $\mathrm{U}-3 \mathrm{ej}$ ) are located within one kilometer of well U-3cn \#5 (Figure 22). Potentiometric data (Winograd and Thordarson, 1975) indicate the general direction of groundwater flow in this area to be from the east to the west.

\section{Well Construction}

U-3cn \#5 (Figure 23) was drilled in 1966 to a total depth of $923.5 \mathrm{~m}$ as a hydrologic test hole to evaluate radionuclide transport resulting from the underground test conducted in emplacement hole U-3cn, located approximately $122 \mathrm{~m}$ upgradient from U-3cn \#5. Land surface elevation at the U-3cn \#5 is $1222.9 \mathrm{~m}$ MSL. 


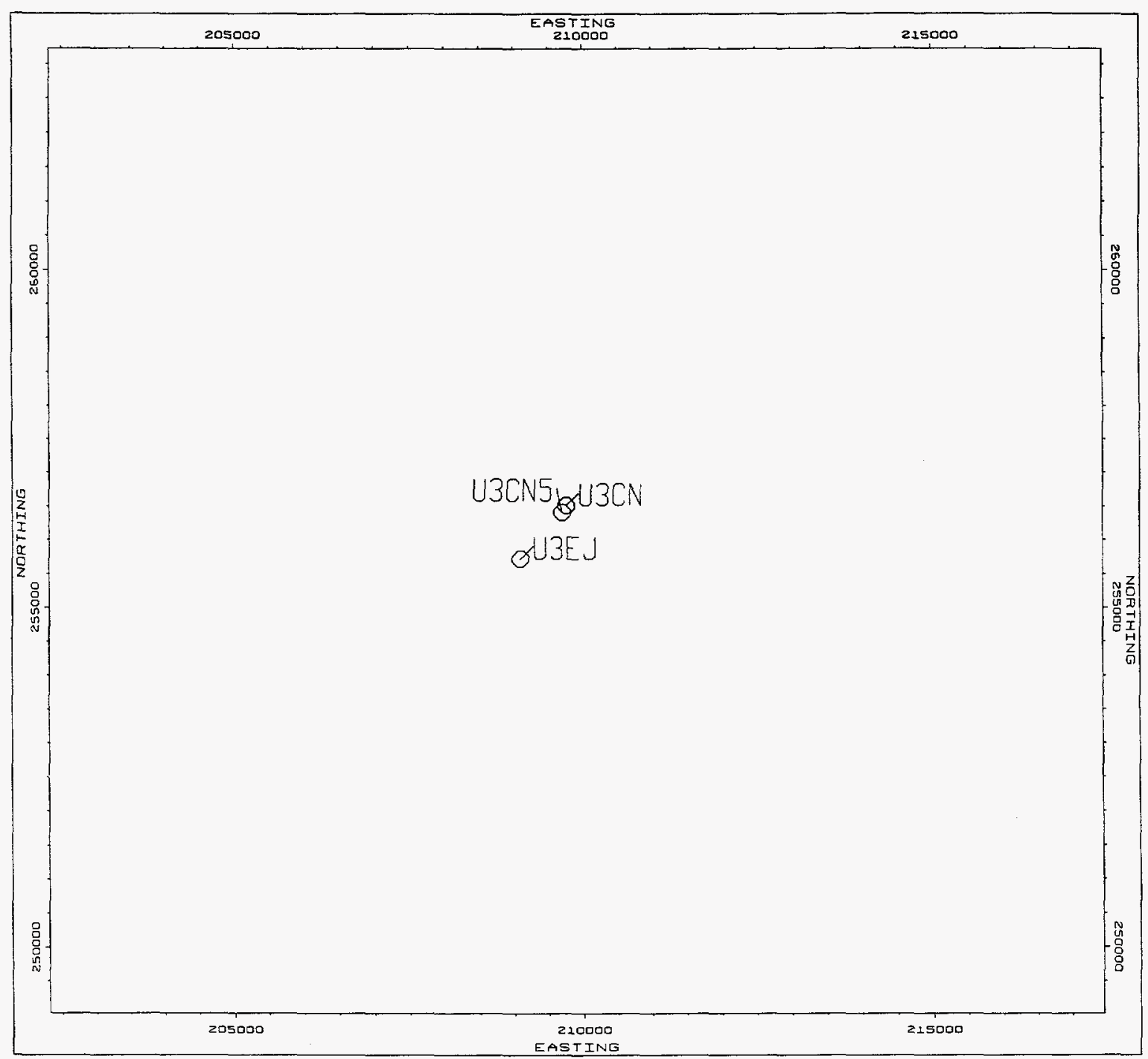

Figure 22. Map showing relative location of U-3cn \#5, U-3ej and U-3cn. 


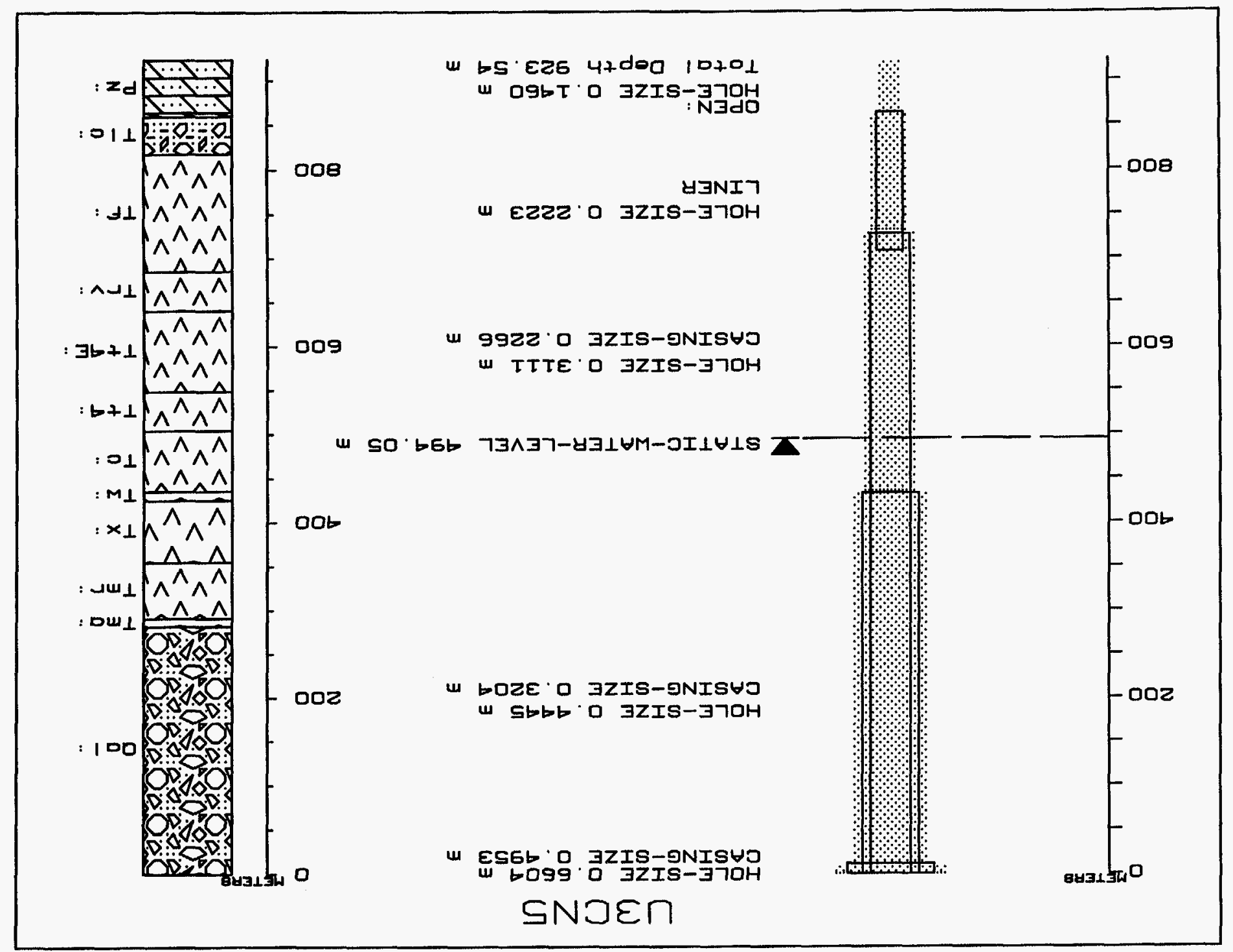


During construction of U-3cn \#5, 24.4-cm-diameter casing was placed within the hole to $726.9 \mathrm{~m}$. To cement the bottom of this casing, $40.72 \mathrm{~m}^{3}$ of cement was placed in the hole, filling the annular space between the casing and the borehole up to a depth of $708 \mathrm{~m}$. Drilling then continued to a depth of $864.1 \mathrm{~m}$. At this point, a steel liner, $16.8 \mathrm{~cm}$ in diameter, was placed in the hole from 707.4 to $863.2 \mathrm{~m}$. The borehole below the liner, and the annular space between the liner and the borehole, was cemented from 837 to $864.1 \mathrm{~m}$ (Tertiary/Paleozoic contact within the well at $859.9 \mathrm{~m}$ ). The top of this liner was hung on a "lead seal" liner hanger. Initial testing by filling the casing with water indicated a leak in the casing. A packer on tubing was set within the liner and a test with $500 \mathrm{psi}$ air pressure indicated a good seal. The packer was then raised to within the casing, and again a test with $500 \mathrm{psi}$ air pressure indicated a good seal. Drilling then continued to total depth using a 14.6-cm-diameter bit. Depth to static water level in the well following construction was reported at approximately $494 \mathrm{~m}$.

Paleozoic carbonate units were penetrated by the wellbore from $859.9 \mathrm{~m}$ to total depth. The carbonate aquifer is overlain by members of the tuff confining unit within the saturated portion of the well (Figure 23).

In June 1994, a site visit was conducted by DRI personnel to determine the condition of the wellhead. A submersible pump and monitoring line are installed in the well. The operational status of the pump is unknown. A USGS transducer and wireline are installed in the monitoring line. The pump tubing exiting from the well is connected to a pipeline leading to a sump located just outside of the collapse crater.

\section{Discussion/Recommendations}

Due to the close proximity of U-3cn \#5 to the test conducted in emplacement hole U-3cn, samples collected from this well could provide valuable information on radionuclide transport in the carbonate aquifer.

The cement placed around the bottom of the liner in the well effectively isolates the Tertiary and Paleozoic intervals penetrated by the wellbore. However, a failure of the "lead seal" liner hanger within the well would provide an avenue for cross flow between permeable units within the Tertiary interval and the Paleozoic carbonate aquifer. Although this seal was tested during construction of the well, its present condition is unknown, and efforts should be made to test its integrity.

If it is determined that the seal is leaking, it would be possible to prevent possible cross flow between the Tertiary and Paleozoic intervals within the well by placing a packer on tubing in the well at some point within the portion of the liner, which is cemented in the hole. Inflation of this packer would isolate the Tertiary and Paleozoic intervals within the well. Using larger-diameter tubing above the liner top would still permit installation of a pump and monitoring line within the well.

If it is determined that the seal is functional, then the only effort required at U- $3 \mathrm{cn} \# 5$ should be wellhead rehabilitation to prevent contamination of the well by surface water, or other 
materials. Since only the tuff confining units are penetrated by the well in the saturated zone, integrity of the seal may be considered of minor importance.

\section{UE-5n}

Two announced underground nuclear tests (U-5b and U-5e) were conducted near or below the water table within one kilometer of well UE-5n in Frenchman Flat (Figure 24). Potentiometric data (Winograd and Thordarson, 1975) indicate the water table in this area of Frenchman Flat to be essentially flat, however, the general direction of groundwater flow would appear to be from the northwest towards the southeast. U-5e and U-5b are located approximately $560 \mathrm{~m}$ northwest (upgradient) and southeast (downgradient) of UE-5n, respectively.

\section{Well Construction}

UE-5n was drilled in 1976 as a exploration hole to a total depth of $514.2 \mathrm{~m}$ (Figure 25). Land surface elevation at the drill site is $948.6 \mathrm{~m} \mathrm{MSL}$. Surface casing, $50.8 \mathrm{~cm}$ in diameter, was placed within the well to a depth of $24.2 \mathrm{~m}$. The annular space between this casing and the borehole was cemented to the surface. Below the surface casing, 38.1-cm borehole was drilled to total depth. The well was completed with $27.3-\mathrm{cm}$-diameter casing set to a depth of $464.2 \mathrm{~m}$. This casing, which did not contain slots or perforations, was landed at the surface on the $50.8-\mathrm{cm}$-diameter surface casing and cemented at the bottom. The bottom of the casing was cemented by pumping cement down the casing followed by a wiper plug. The wiper plug was pushed down the casing by water displacing the cement into the annular space between the casing and the wellbore. At some time following completion of the well, the 27.3-cm-diameter casing was perforated between 219.5 and $222.5 \mathrm{~m}$. No record could be found concerning the number or size of the perforations or the date the perforations were made.

On July 23, 1991, DRI personnel obtained a temperature/electrical conductivity log in well UE-5n. Fluid level in the well was measured at $214.5 \mathrm{~m}$. Total depth was measured at $361.2 \mathrm{~m}$. The total depth measured in the well is approximately $100 \mathrm{~m}$ higher than the expected total depth of the well following cementing of the $27.3-\mathrm{cm}$-diameter casing within the well. The reduction in total depth may be due to a foreign object, such as a rock, having been dropped into the well. During placement of the cement, it was reported that the wiper plug used to push the cement down the casing did not lock into the baffle plate located in the top of the lowest section of casing. The cement may not have been pumped far enough down the casing, or perhaps after pumping, the cement flowed from the annulus back into the casing, pushing the plug back up the casing. The total depth measured at 361.2 m may represent the location of the wiper plug within the casing.

\section{Discussion/Recommendations}

UE- $5 \mathrm{n}$ is not currently sampled as part of the NTS groundwater monitoring network. Water samples obtained from UE-5n for the HRMP have been determined to have a tritium concentration of approximately $10,000 \mathrm{pCi} / \mathrm{L}$ (DOE, 1993; 1994). Although located within one kilometer of two underground tests conducted near or below the water table (Figure 24), UE-5n 


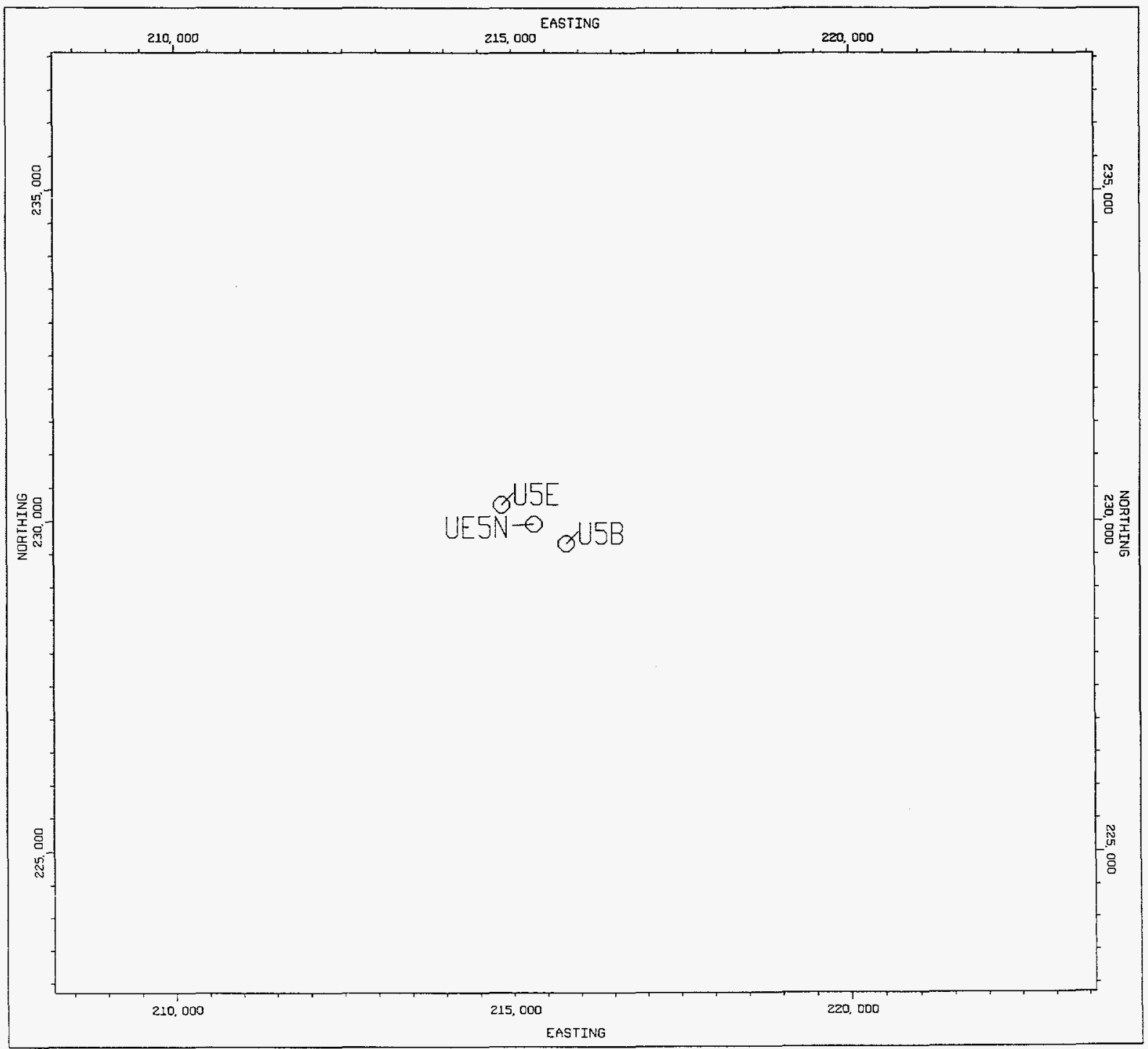

Figure 24. Map showing relative location of UE-5n, U-5e and U-5b. 


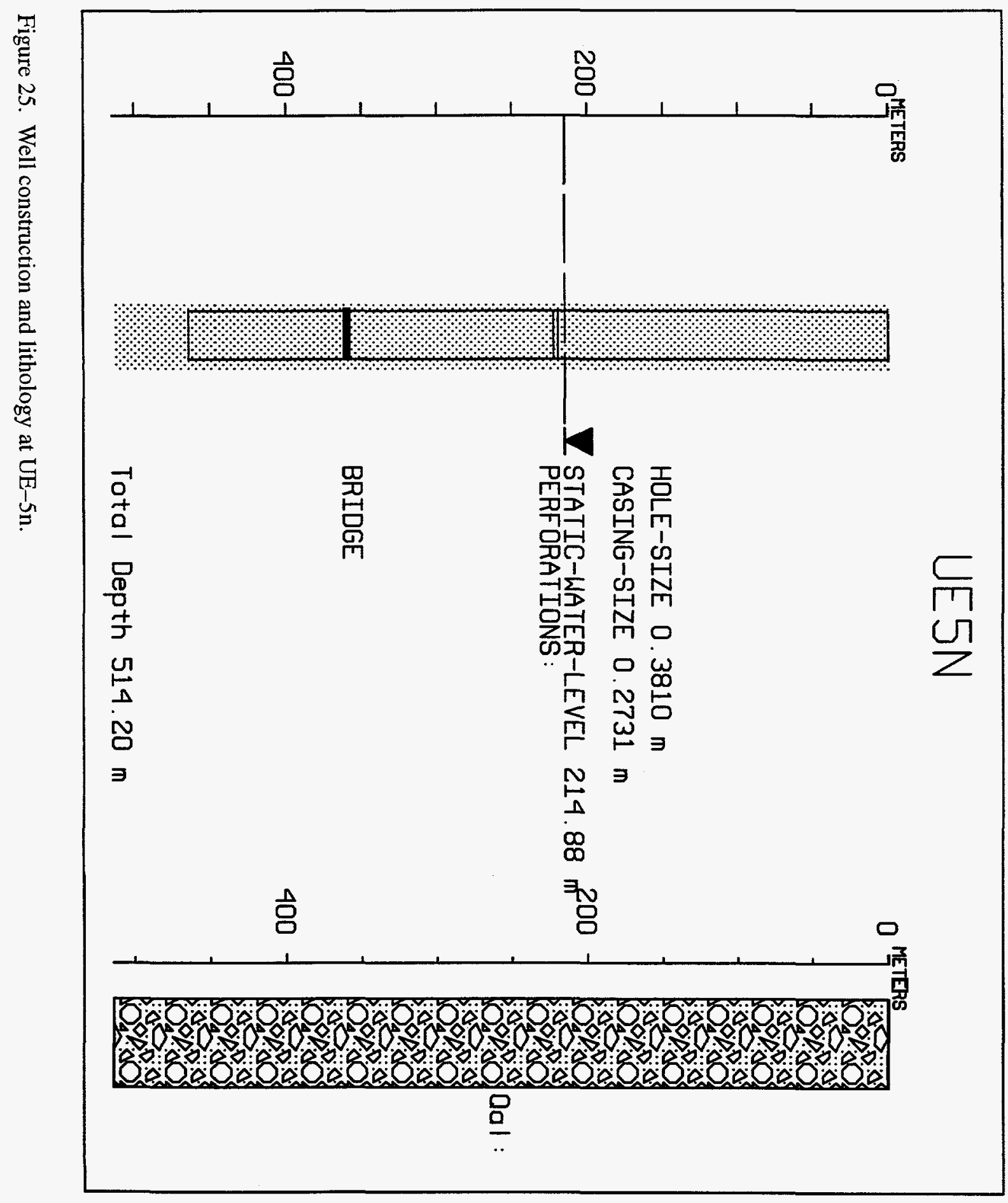


is also located within several tens of meters to the north of the Cambric ditch. The Cambric ditch was used to discharge water from the HRMP well RNM-2 for many years in an effort to induce the migration of radionuclides produced by the underground test conducted in emplacement hole U-5e. The source of the tritium detected in UE-5n is uncertain. Samples collected from UE-5n on a regular basis could provide valuable data on radionuclide transport in the saturated zone and possibly on artificial recharge rates in the vadose zone. This sampling would be facilitated by the installation of a Moyno pump and monitoring line within the well.

In June 1994, DRI personnel conducted a site visit to UE-5n to determine the condition of the wellhead. The wellhead consisted of $15 \mathrm{~cm}$ of $121.9-\mathrm{cm}$-diameter conductor pipe extending above ground level. Inside this conductor pipe, $15 \mathrm{~cm}$ of the $50.8-\mathrm{cm}$-diameter surface casing extended above ground level. The 27.3-cm-diameter casing, landed on the 50.8-cm-diameter casing, extended $104 \mathrm{~cm}$ above ground level. The cover for the $27.3-\mathrm{cm}$-diameter casing consisted of an inverted mop bucket placed over the top of the casing.

A subsequent site visit revealed that the wellhead at UE-5n has been rehabilitated in compliance with EPA guidelines and Nevada state requirements. The 27.3-cm-diameter casing at UE-5n was extended to approximately $1.5 \mathrm{~m}$ above ground level. Additionally, a square concrete pad (approximately $3 \mathrm{~m}$ on a side) which slopes away from the casing has been placed around the wellhead. The mop bucket has been replaced with a watertight, lockable, threaded steel cap.

\section{UE-20n \#1}

Four underground nuclear tests (U-20a, U-20n, U-20av, and U-20ac) were conducted near (within $25 \mathrm{~m}$ ) or below the water table within one kilometer of the well UE-20n \#1 (Figure 26). The test conducted at U-20n was detonated $542 \mathrm{~m}$ below the water table and is located $300 \mathrm{~m}$ northwest of well UE-20n \#1. Potentiometric data (Winograd and Thordarson, 1975) indicate the general direction of groundwater flow in this area to be from the northeast towards the southwest.

\section{Well Construction}

UE-20n \#1 (Figure 27) was drilled in 1987 as an exploration well to a total depth of 1005.8 $\mathrm{m}$. Land surface elevation at the well site is $1969.2 \mathrm{~m} \mathrm{MSL}$. The well was completed with 24.4-cm-diameter casing to a depth of $695.4 \mathrm{~m}$. This casing was not cemented to the surface. The annular space between the casing and the wellbore was cemented up to a depth of $621.4 \mathrm{~m}$. Fluid level within the well is reported at 622.6 below land surface.

Following construction of the well, a bridge plug was set within the open borehole at 866 $\mathrm{m}$. To ensure the integrity of the seal, $0.07 \mathrm{~m}^{3}$ of sand, followed by $0.14 \mathrm{~m}^{3}$ of cement, was placed above the bridge plug. A Moyno pump and fluid level monitoring line were then placed within the hole (intake for pump set at $694.9 \mathrm{~m}$ ) and the well pumped periodically (average drawdown of $1.4 \mathrm{~m}$ at a pumping rate of 56.8 liters minute ${ }^{-1}$ ) in an effort to induce radionuclide migration 


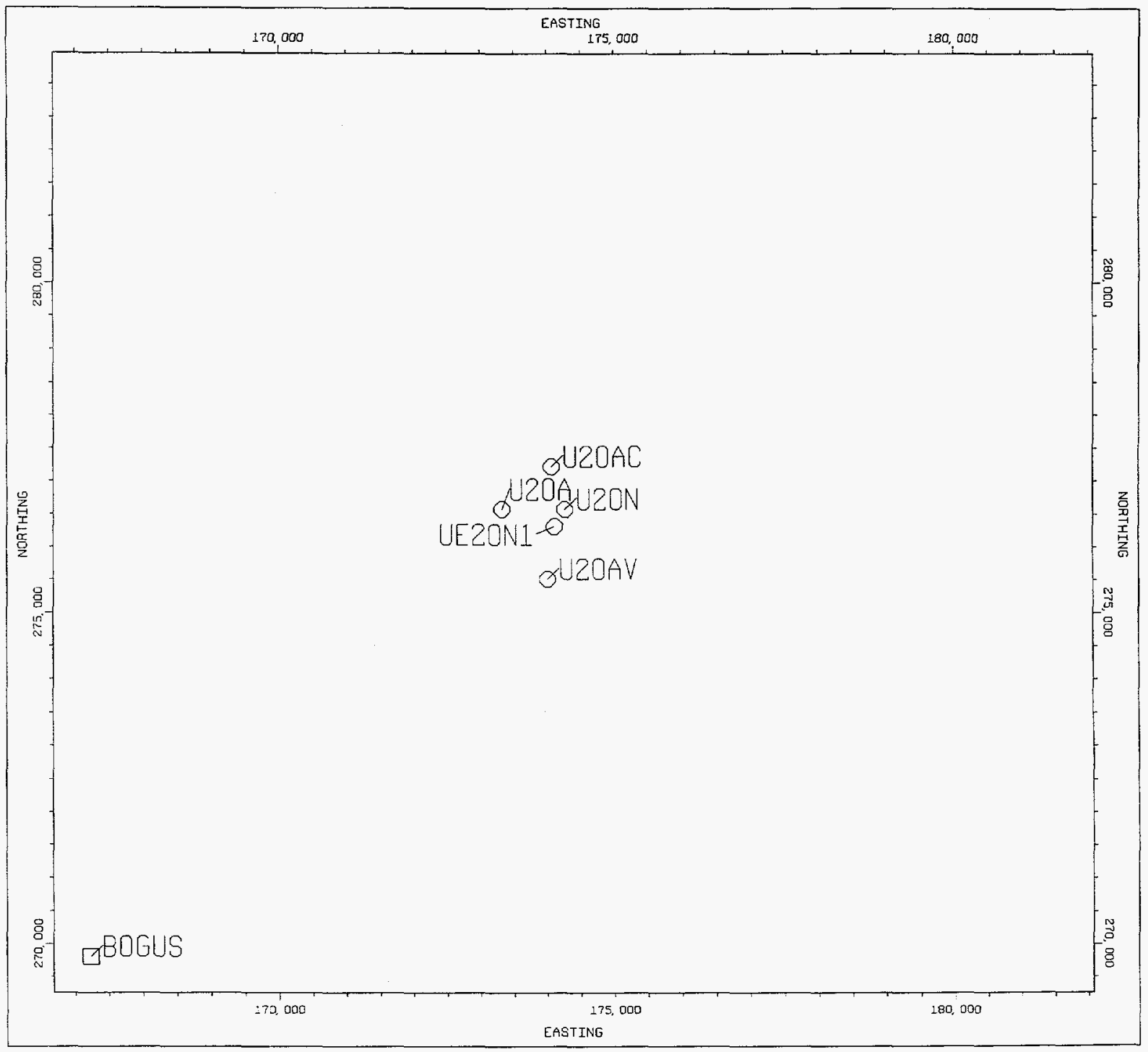

Figure 26. Map showing relative location of U-20ac, U-20a, U-20n, U-20av and UE-20n \#1. 


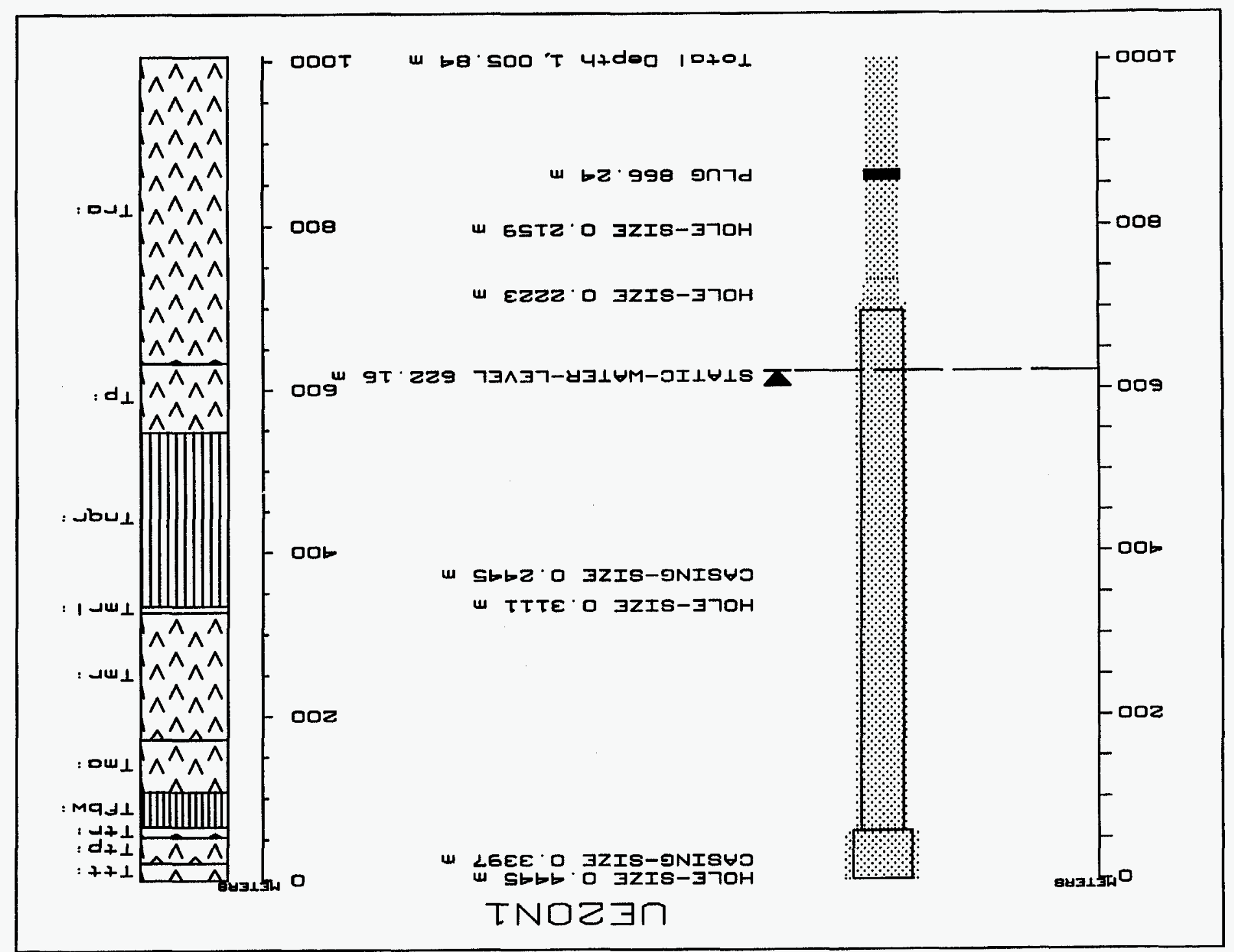


from the collapse chimney created by the test conducted at U-20n. A detailed description of the drilling, completion, logging, and sampling activities conducted at UE-20n \#1 can be found in "Report of Drilling and Radionuclide Migration Investigations at UE-20n \#1, Pahute Mesa, Nevada Test Site, 1987," by Susan Erikson, 1991.

In July 1994, a site visit was conducted to determine the condition of the wellhead. The pump and monitoring line are still set within the well. It is unknown whether the pump is functional.

\section{Discussion/Recommendations}

As constructed, UE-20n \#1 does not appear to pose a threat from cross-aquifer contamination. UE-20n \#1 is located immediately downgradient from U-20n and has been the site of extensive investigation into the transport of radionuclides produced by underground testing and could provide additional information in the future if sampled on a regular basis.

The Moyno pump should be tested and replaced if necessary. The presence of a functional pump and monitor line will permit the well to be purged and sampled on a regular basis and water level measurements to be obtained.

To eliminate the possibility of contamination to the well by surface water or other materials, the wellhead at UE-20n \#1 should be rehabilitated.

\section{UE-4t}

Ten underground nuclear tests (U-4o, U-4d, U-4l, U-4g, U-4q, U-4t, U-4c, U-4j, U-7ap, and U-7br) were conducted near (within $25 \mathrm{~m}$ ) or below the water table within one kilometer of well UE-4t (Figure 28). All ten of the these tests were detonated between 100 and $500 \mathrm{~m}$ below the water table. Potentiometric data (Winograd and Thordarson, 1975) indicate the general direction of groundwater flow in this area to be from the north towards the south.

\section{Well Construction}

UE-4t was drilled as an exploratory well in 1987 (Figure 29). The well was drilled using rotary tools with conventional circulation with air-foam. An initial 66-cm-diameter borehole was drilled to a depth of $36.9 \mathrm{~m}$. Surface casing, $34 \mathrm{~cm}$ in diameter, was then placed within the borehole to a depth of $36.2 \mathrm{~m}$. The annular space between this casing and the borehole was then cemented to the surface. A $25.1-\mathrm{cm}$-diameter hole was then drilled from $36.9 \mathrm{~m}$ to a total depth of $735.5 \mathrm{~m}$. Land surface elevation at the site is $1263 \mathrm{~m}$ MSL. Following construction, depth to static water level in the well was reported at $532.2 \mathrm{~m}$ below ground level.

In 1989, hydrologic tests were conducted in UE-4t using straddle packers set on 7.3-cm-diameter tubing. These hydrologic tests were conducted to investigate elevated fluid levels observed in Yucca Flat. The results of these tests are well documented in the report "Hydrologic Testing in Exploratory Drill Hole UE4t, Yucca Flat, the Nevada Test Site" (Hawkins, Trudeau, and Mihevc, 1989). 


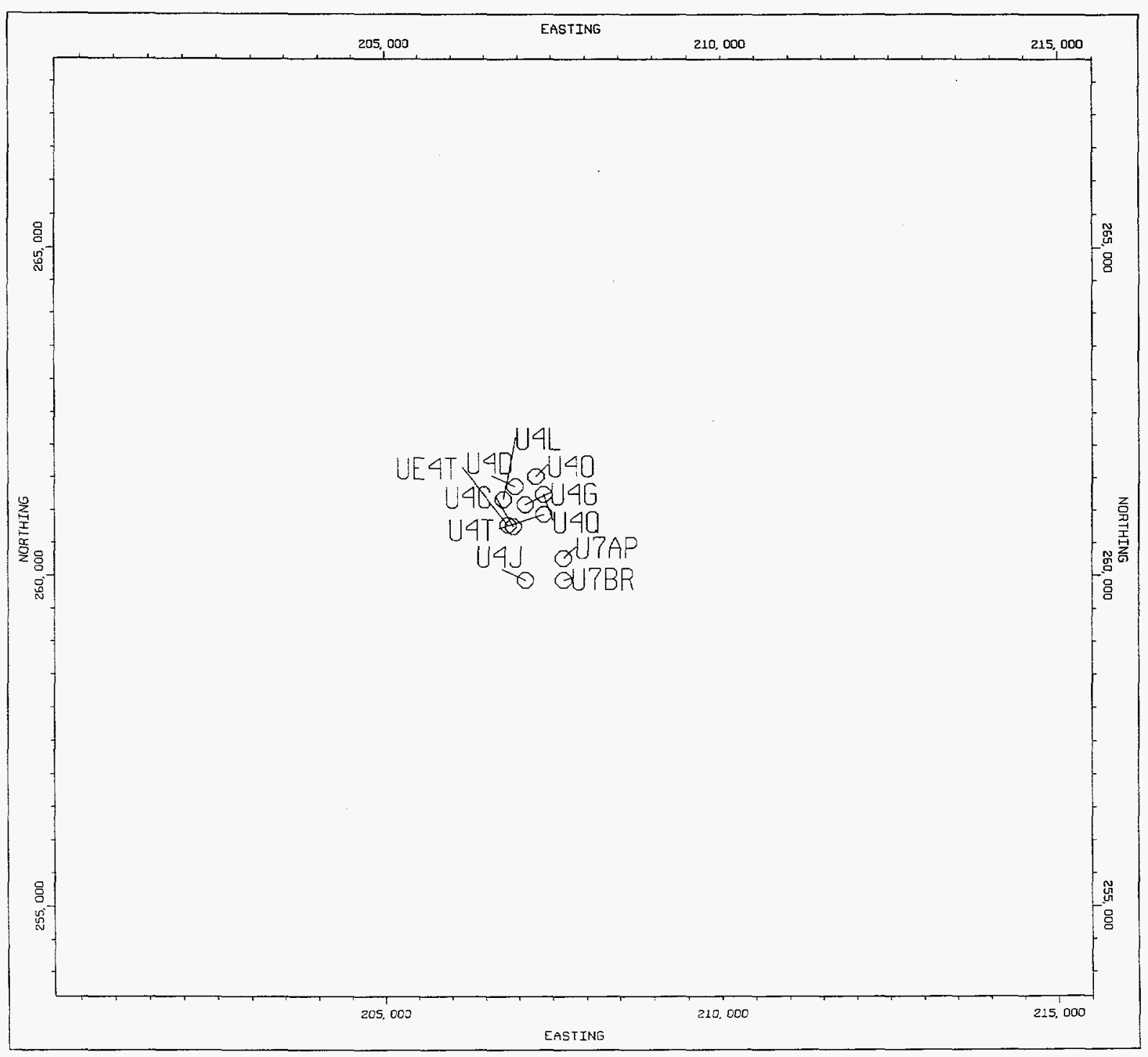

Figure 28. Map showing relative location of U-4o, U-4d, U-4q, U-4l, U-4g, U-4t, U-4c, U-7ap, U-4j, U-7br and UE-4t. 


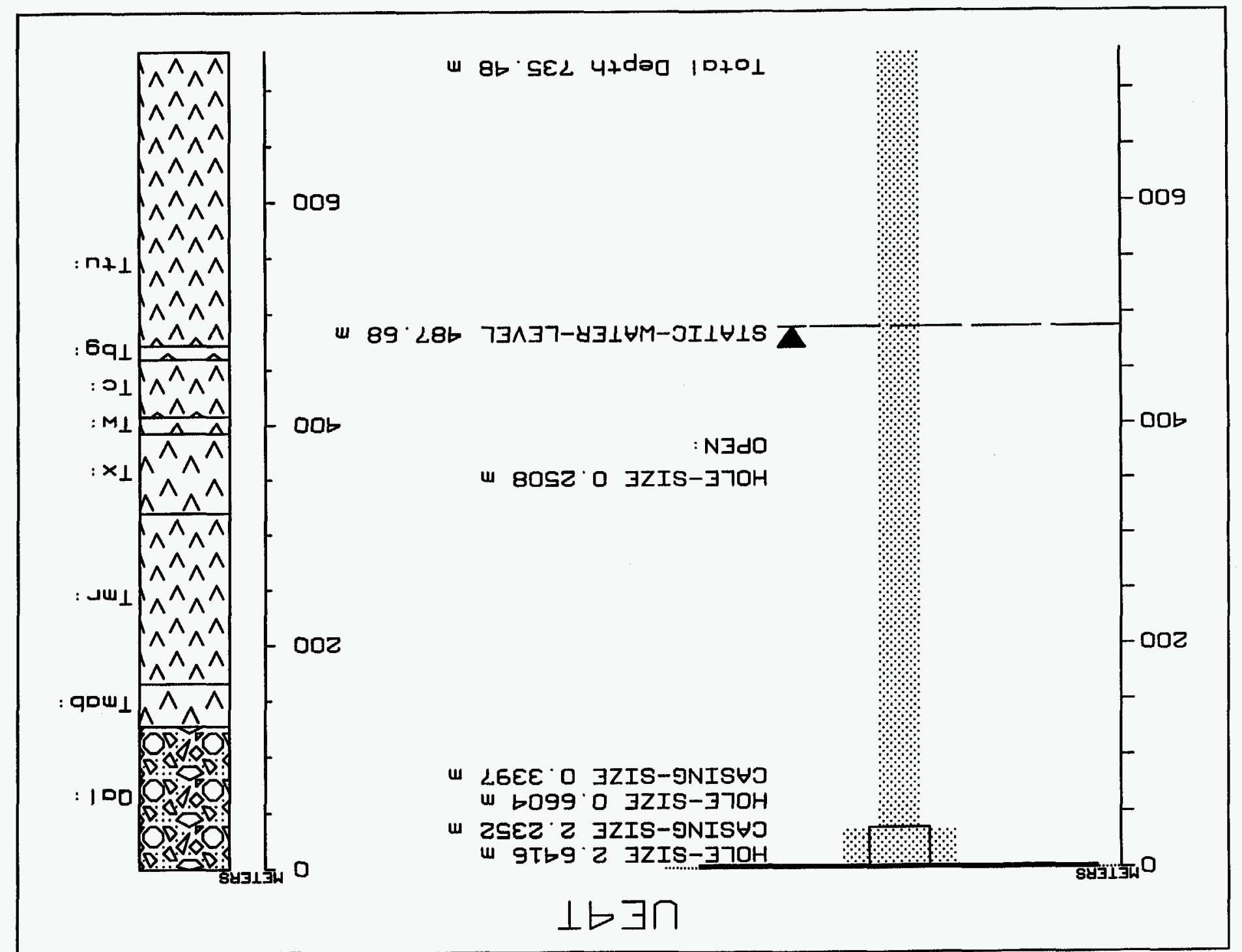


In 1989, two strings of 7.3-cm-diameter tubing were placed in the existing borehole at UE-4t. String \#1 was run to $607.2 \mathrm{~m}$, string \#2 was run to a depth of $525.5 \mathrm{~m}$. String \#1 contained a slotted interval between $598.3 \mathrm{~m}$ and $607.2 \mathrm{~m}$. String \#2 contained a slotted interval between $508 \mathrm{~m}$ and $525.5 \mathrm{~m}$. The slotted interval of both strings were gravel packed and the tubing cemented within the original wellbore. After recompletion of the well, it appeared that some cement had penetrated the gravel pack and entered the tubing through the upper portion of each slotted interval, and the tubing strings were not in good communication with the formations.

In 1992, both tubes at UE-4t were developed by drilling out the cement inside the tubings and swabbing both tubes. String \#1 was cleaned to total depth at $607.2 \mathrm{~m}$, however, string \#2 could only be cleaned to a depth of $518.2 \mathrm{~m}$. Following development of the tubing strings, depth to water in string \#1 was reported at $95.7 \mathrm{~m}$ below ground level. Depth to water in string \#2 was reported at $358.4 \mathrm{~m}$ below ground level. Both zones are within the Tunnel Beds Tertiary volcanic units.

DRI personnel conducted a site visit to determine the condition of the wellhead. Approximately $75 \mathrm{~cm}$ of the 34-cm-diameter casing extends above ground level. Inside and below the top of this casing are the two tubing strings. Both tubing strings are sealed with plastic thread protector caps and the surface casing has a lockable hinged lid.

\section{Discussion/Recommendations}

UE-4t is currently scheduled for sampling as part of the NTS groundwater monitoring network, however, samples could not be obtained since development due to water level monitoring equipment installed in string \#1. UE-4t is located downgradient from several underground nuclear tests conducted near or below the water table (Figure 29), and samples collected from UE-4t on a regular basis could provide valuable data on radionuclide transport in the saturated zone. Additionally, time-series water-level measurements could provide valuable information on elevated water levels in Yucca Flat.

The wellhead at UE-4t should be rehabilitated to comply with EPA guidelines and Nevada state regulations.

\section{U-10 L\#1}

Two underground nuclear tests (U-9cb and U-10af) were conducted near (within $50 \mathrm{~m}$ ) or below the water table within one kilometer of well U-10L \#1 (Figure 30). U-9cb is located approximately $0.8 \mathrm{~km}$ south of well $\mathrm{U}-10 \mathrm{~L} \# 1 ; \mathrm{U}-10$ af is located approximately $0.8 \mathrm{~km}$ west of well U-10L \#1. Potentiometric data (Winograd and Thordarson, 1975) indicate the general direction of groundwater flow in this area to be from the north towards the south.

\section{Well Construction}

U-10L \#1 was drilled as an "instrument hole" in 1964 to a total depth of $673 \mathrm{~m}$ below land surface using air and Davis mix as the circulation medium. Land surface elevation at the site is $1299.8 \mathrm{~m}$ MSL. In construction of the well, a $38.1-\mathrm{cm}$-diameter hole was drilled to $419.1 \mathrm{~m}$, where $27.3-\mathrm{cm}$-diameter casing was set and the annular space between the casing and the 


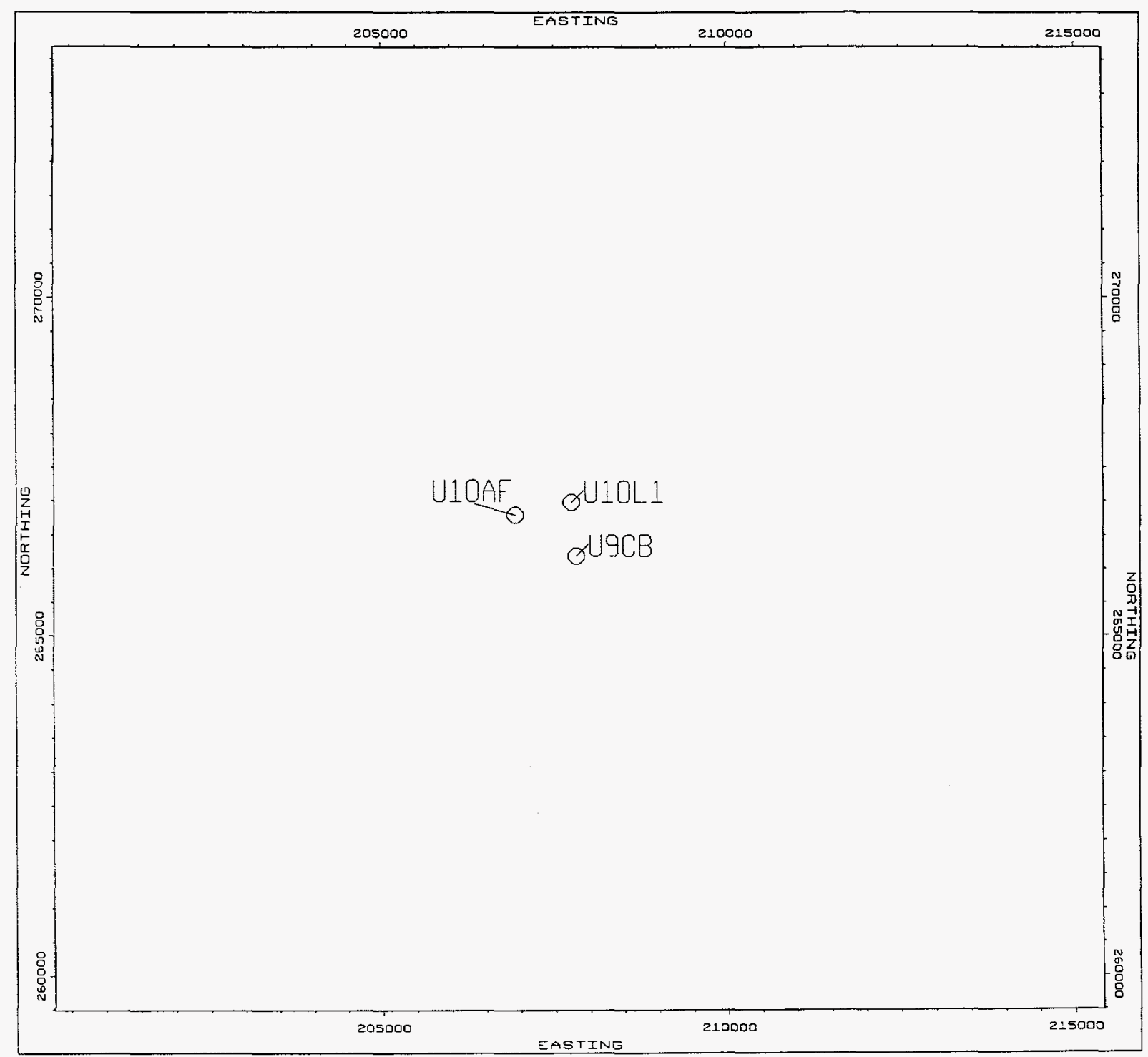

Figure 30. Map showing relative location of U-9cb, U-10af and U-10L \#1. 


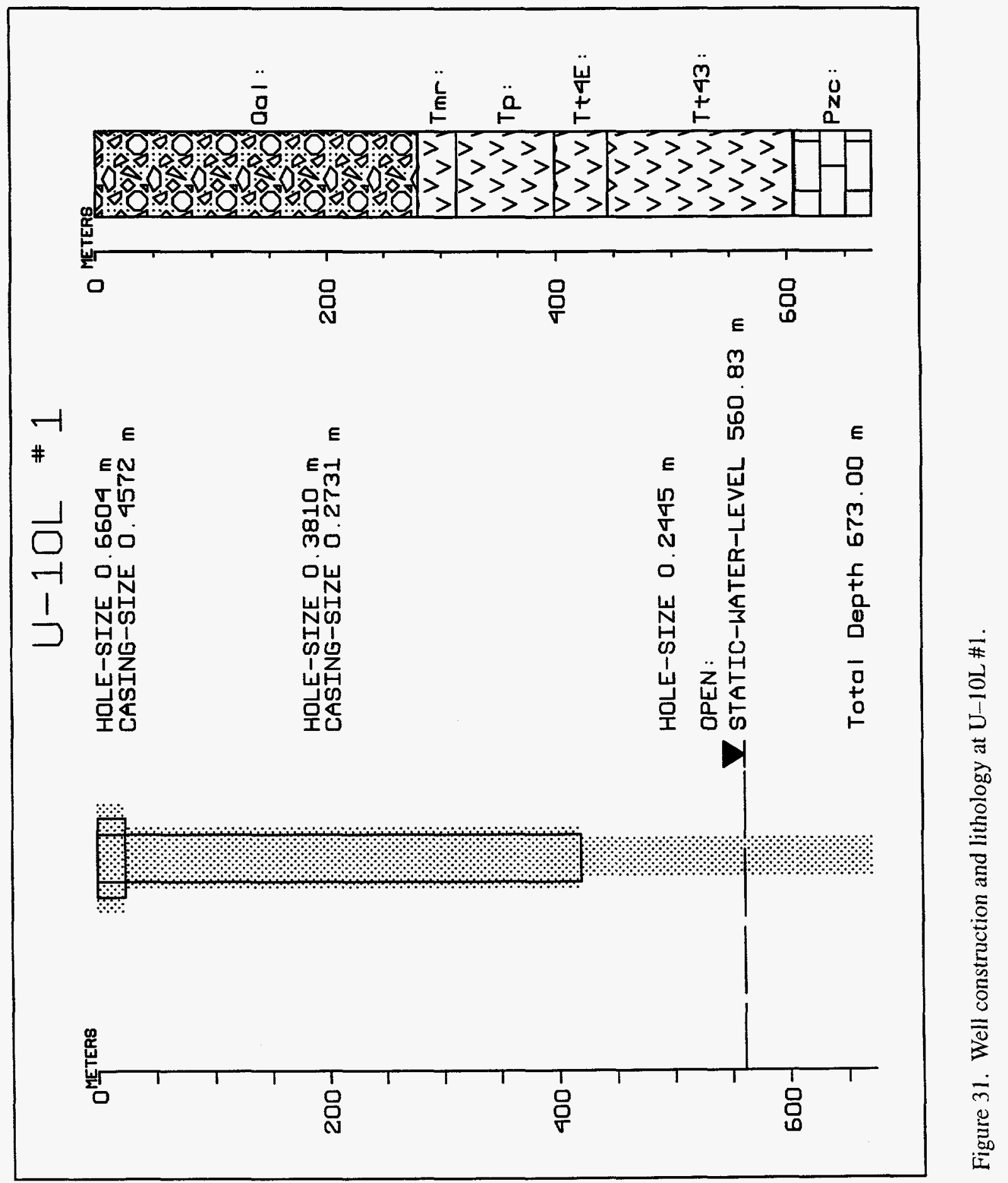


wellbore cemented to the surface. A $25.1-\mathrm{cm}$-diameter bit was then used to drill to total depth. During drilling of the $25.1-\mathrm{cm}$-diameter borehole, cores were obtained at various intervals between 448.1 and the total depth of the well at $673 \mathrm{~m}$.

Following construction of the well, hydrologic tests were conducted by the USGS using Lynes packers to isolate various intervals within the wellbore. After completion of the hydrologic tests, static water level in the well was reported at $560.8 \mathrm{~m}$ below land surface.

U-10L \#1 penetrated dolomite Paleozoic carbonate units at a depth of $605.9 \mathrm{~m}$ below land surface. Within the saturated interval, these carbonate units are overlain by a confining unit composed of air-fall and reworked Tunnel Beds tuffs.

During a total depth/fluid level check conducted by DRI personnel in 1995, a bridge was found at a depth of $566.4 \mathrm{~m}$; slightly below the static water level reported following construction of the well, however, fluid was not encountered. Several attempts were made to work past the obstruction with no success. The tool returned to the surface completely dry, with rust and sediment compacted into the nose of the tool.

The wellhead at U-10L \#1 consists of a small concrete pad surrounding the surface casing and 27.3-cm-diameter casing at ground level. The surface casing extends approximately $38 \mathrm{~cm}$ above the concrete pad; the $27.3-\mathrm{cm}$-diameter casing extends approximately $46 \mathrm{~cm}$ above the concrete pad. The 27.3-cm-diameter casing is fitted with a hinged lid.

\section{Discussion/Recommendations}

U-10L \#1 is located in northern Yucca Flat, where monitoring locations in the carbonate aquifer are not currently available. Due to the relatively large-diameter $(27.3 \mathrm{~cm})$ casing present in the well, U-10L \#1 could easily be cleaned of bridges and fill to its original total depth. Geophysical logs and hydrologic tests could be conducted and the hole deepened if desirable. The well could then be recompleted with $14-\mathrm{cm}$-diameter slotted casing. The casing would be screened and gravel packed over the carbonate interval and the annular space above the gravel pack cemented to the surface. The 14-cm-diameter casing would permit the installation of a Moyno pump and monitoring line to facilitate periodic sampling of the well and water-level monitoring.

The wellhead at U-10L \#1 should be rehabilitated to comply with EPA guidelines and Nevada state regulations.

\section{U-9 ITS UE-U-29 \#1 and U-9 ITS UE-U-29 \#2}

U-9 ITS UE-U-29 \#1 and U-9 ITS UE-U-29 \#2 were both drilled in 1971, as exploration wells in northern Yucca Flat. One underground nuclear test (U-9cb) was conducted near (within $50 \mathrm{~m}$ ) or below the water table within one kilometer of wells U-9 ITS UE-U-29 \#1 and U-9 ITS UE-U-29 \#2 (Figure 32). The test conducted at U-9cb was detonated approximately $23 \mathrm{~m}$ above the water table. U-9 ITS UE-U-29 \#1 and U-9 ITS UE-U-29 \#2 are located approximately 162 


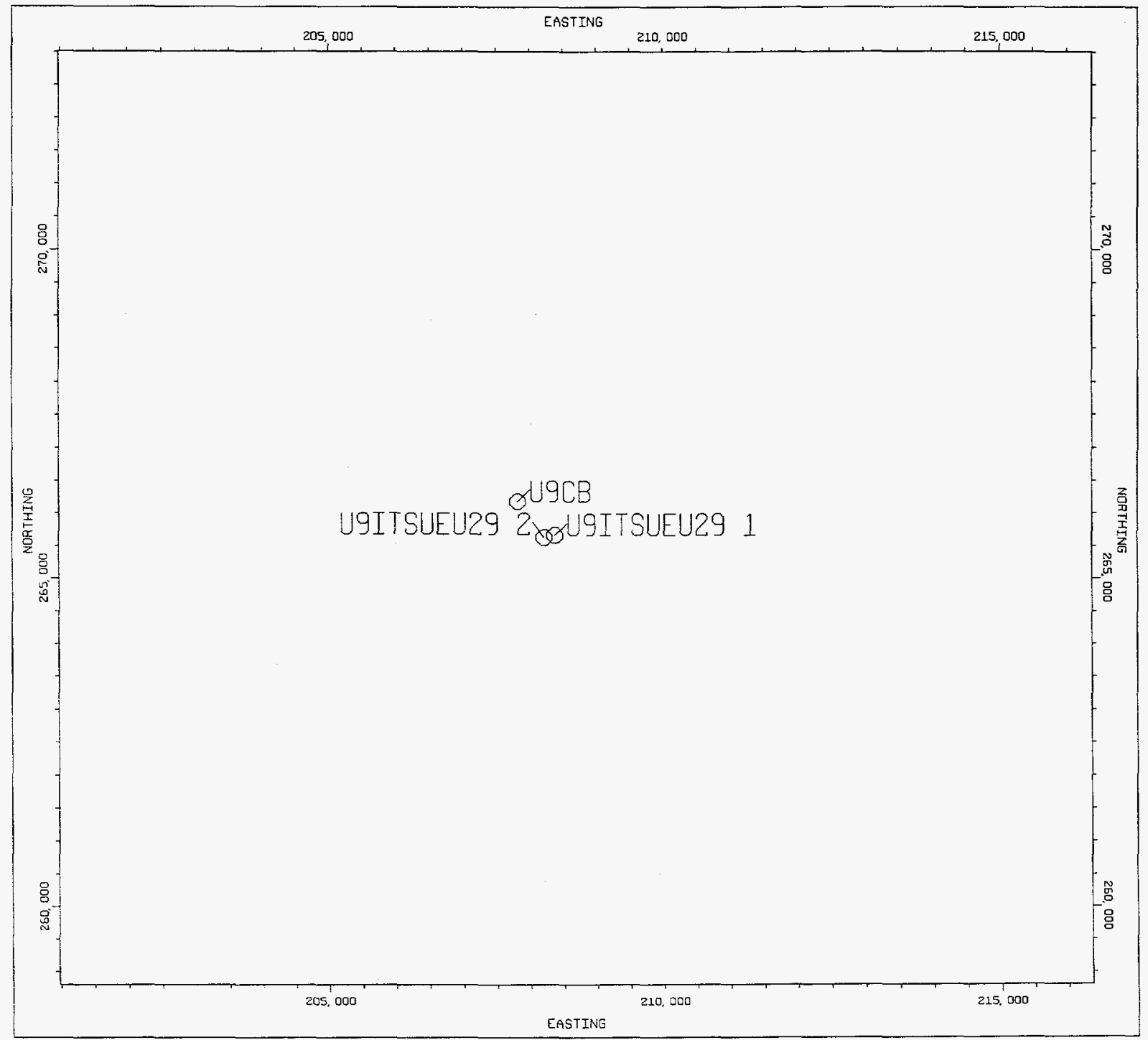

Figure 32. Map showing relative location of U-9 ITS UE-U-29 \#1, U-9 ITS UE-U-29 \#2 and $\mathrm{U}-9 \mathrm{cb}$. 
m from one another, approximately $0.7 \mathrm{~km}$ southeast of U-9cb. Potentiometric data (Winograd and Thordarson, 1975) indicate the general direction of groundwater flow in this area to be from the north towards the south.

\section{Well Construction}

U-9 ITS UE-U-29 \#1

U-9 ITS UE-U-29 \#1 (Figure 33) was drilled to a total depth of $380.4 \mathrm{~m}$ using rotary tools with conventional circulation using air-foam. A 66-cm-diameter hole was drilled to a depth of $24.4 \mathrm{~m}$, where $34-\mathrm{cm}$-diameter casing was set from the surface to $23.5 \mathrm{~m}$. The annular space between this casing and the wellbore was cemented to the surface. Below this casing, 31.1-cm-diameter hole was drilled to total depth. During construction, four 3-m cores were cut at various intervals from $155.4 \mathrm{~m}$ to total depth with good recovery. Surface elevation at the site is $1294.8 \mathrm{~m}$ MSL.

Following construction of the well, static fluid level in the well was reported at $377.9 \mathrm{~m}$ below land surface, just above total depth of the well. It is not known whether this represents the position of the water table or was fluid remaining in the well following construction. However, potentiometric data (Winograd and Thordarson, 1975) indicate the static water level in the area to be near the total depth of well U-9 ITS UE-U-29 \#1. U-9 ITS UE-U-29 \#1 penetrates into Paleozoic carbonate units, which are overlain by Tunnel Beds tuff units.

In 1995, DRI personnel performed a total depth/fluid level check in the well. Total depth was measured at $371.9 \mathrm{~m}$. Fluid was not detected in the well.

The wellhead at U-9 ITS UE-U-29 \#1 consists of approximately $30 \mathrm{~cm}$ of the 34-cm-diameter casing extending above ground level. The casing is capped with a flat steel plate. The steel plate is not locked or otherwise fastened in place.

\section{$U-9$ ITS UE-U-29 \#2}

U-9 ITS UE-U-29 \#2 (Figure 34) was drilled to a total depth of $479.1 \mathrm{~m}$ using rotary tools with conventional circulation using air-foam. As with U-9 ITS UE-U-29 \#1, a 66-cm-diameter hole was drilled to a depth of $24.4 \mathrm{~m}$, however, in U-9 ITS UE-U-29 \#2, 27.3-cm-diameter casing was placed in the hole to a depth of $24.1 \mathrm{~m}$. Below this casing, 25.1-cm-diameter hole was drilled to total depth. During construction of the well, 32 sidewall cores were taken at various depths between 122.5 and $460.2 \mathrm{~m}$ below land surface. Water-level measurements in the well were not reported. Surface elevation at the site is $1293 \mathrm{~m}$ MSL.

As constructed, U-9 ITS UE-U-29 \#2 should penetrate saturated intervals of Tunnel Beds tuff units and the Paleozoic carbonate aquifer.

In 1995, DRI personnel conducted a site visit to U-9 ITS UE-U-29 \#2 to determine current wellhead and downhole conditions. The wellhead at U-9 ITS UE-U-29 \#2 consists of approximately $30 \mathrm{~cm}$ of the $27.3-\mathrm{cm}$-diameter casing extending above ground level. This casing 


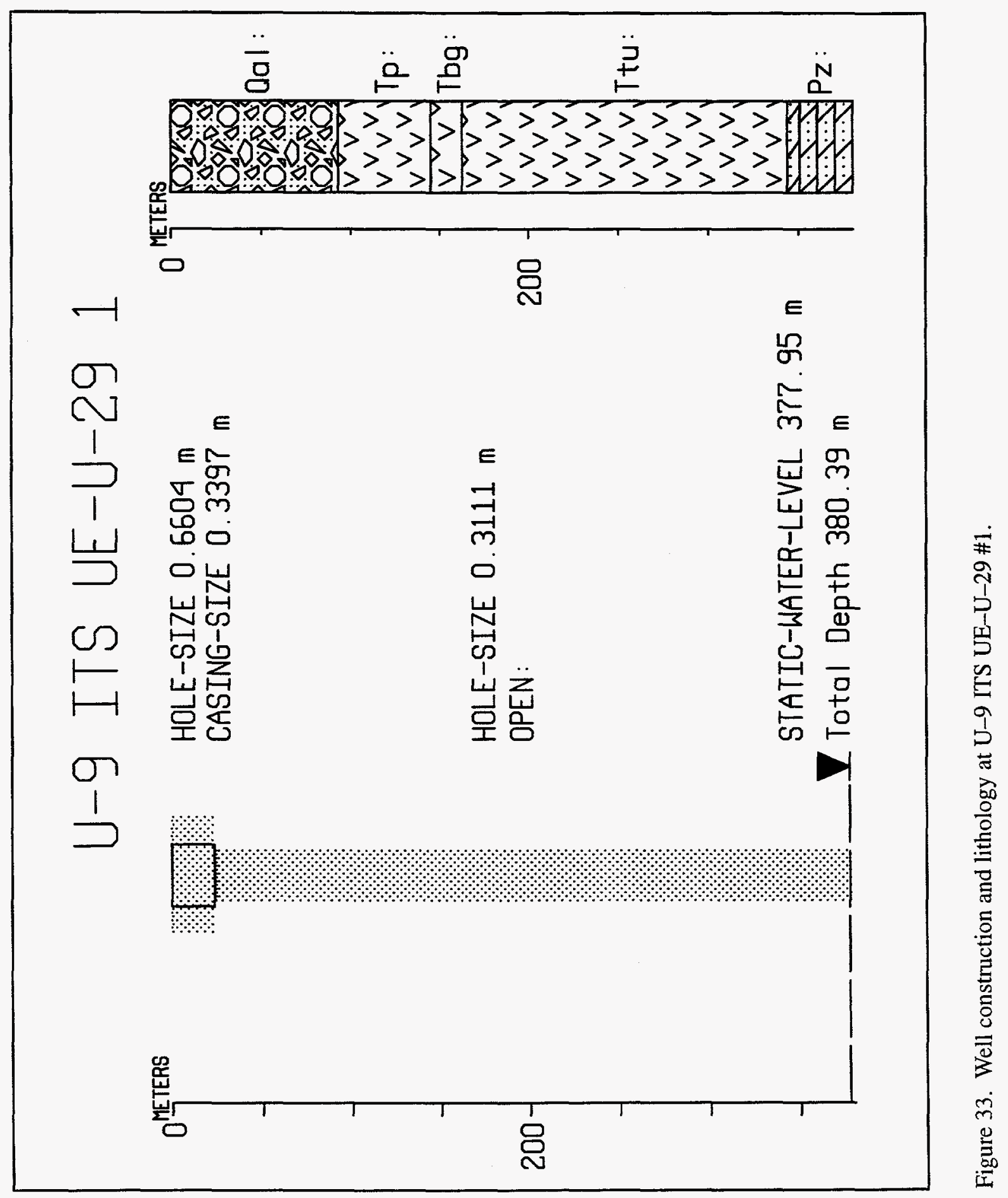


'そ\# 6Z-

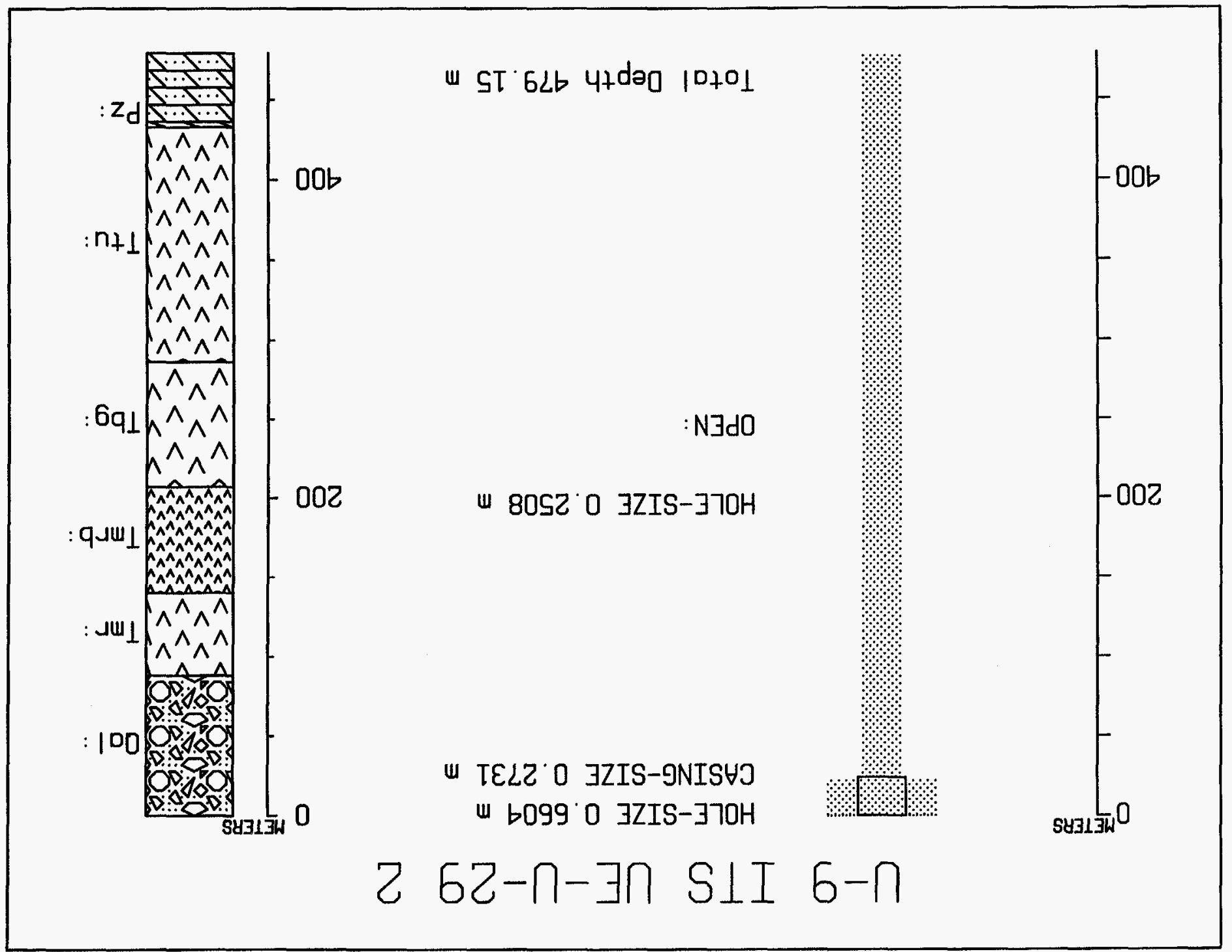


is capped with a flat steel plate welded to the casing. What appears to be 7.3-cm-diameter tubing extends out of the flat steel plate for approximately $70 \mathrm{~cm}$, at which point a hose runs from the tubing to the ground. The tubing above the steel plate is wrapped in fiber insulation. Around the wellhead there is a barbed wire fence approximately $6 \mathrm{~m}$ in diameter. A sign on the north side of this fence warns of radioactive material downhole. Due to the possible presence of radioactive material downhole and the presence of the tubing and possibly other unknown equipment (not recorded in hole history) in the well, total depth and fluid-level checks could not be performed.

The nature of the radioactive material downhole could not be found in the records regarding U-9 ITS UE-U-29 \#2. The condition and status of this well will require further investigation before recommendations concerning the well can be made.

\section{Discussion/Recommendations}

Although the underground test conducted at U-9cb is located $0.7 \mathrm{~km}$ northwest of wells U-9 ITS UE-U-29 \#1 and U-9 ITS UE-U-29 \#2, the wells are located in northern Yucca Flat, where monitoring locations in the carbonate aquifer are not currently available. Additionally, although not directly downgradient, either of these wells could serve as downgradient monitoring locations for the test conducted at $U-9 \mathrm{cb}$, which was detonated approximately $23 \mathrm{~m}$ above the water table.

Due to the relatively large diameters of the casings present in the wells, both (if the condition and status of U-9 ITS UE-U-29 \#2 can be determined), or either, could be cleaned of bridges and fill to their original total depth and deepened to create viable Paleozoic carbonate aquifer monitoring locations. Geophysical logs and hydrologic tests could be conducted and the well(s) could then be recompleted with 14-cm-diameter casing and 4.8-cm-diameter monitoring line(s). The casing and monitoring line(s) would be screened and gravel packed over the carbonate interval and the annular space above the gravel pack cemented to the surface. The 14-cm-diameter casing would permit the installation of a Moyno pump to facilitate periodic sampling of the well(s).

Until action can be taken to recomplete these wells, the wellheads at both locations should be rehabilitated to prevent contamination by surface water, or other materials.

\section{U-9 ITS UE-U-22}

One underground nuclear test (U-9bx) was conducted near (within $25 \mathrm{~m}$ ) or below the water table within one kilometer of well U-9 ITS UE-U-22 (Figure 35). Well U-9 ITS UE-U-22 is located $0.8 \mathrm{~km}$ east of emplacement hole U-9bx. Potentiometric data (Winograd and Thordarson, 1975) indicate the general direction of groundwater flow in the area to be from the northeast towards the southwest. The depth of burial for the event conducted in emplacement hole U-9bx was $582.2 \mathrm{~m}$ below land surface, approximately $24 \mathrm{~m}$ below the estimated depth to the water table of $558.1 \mathrm{~m}$. 


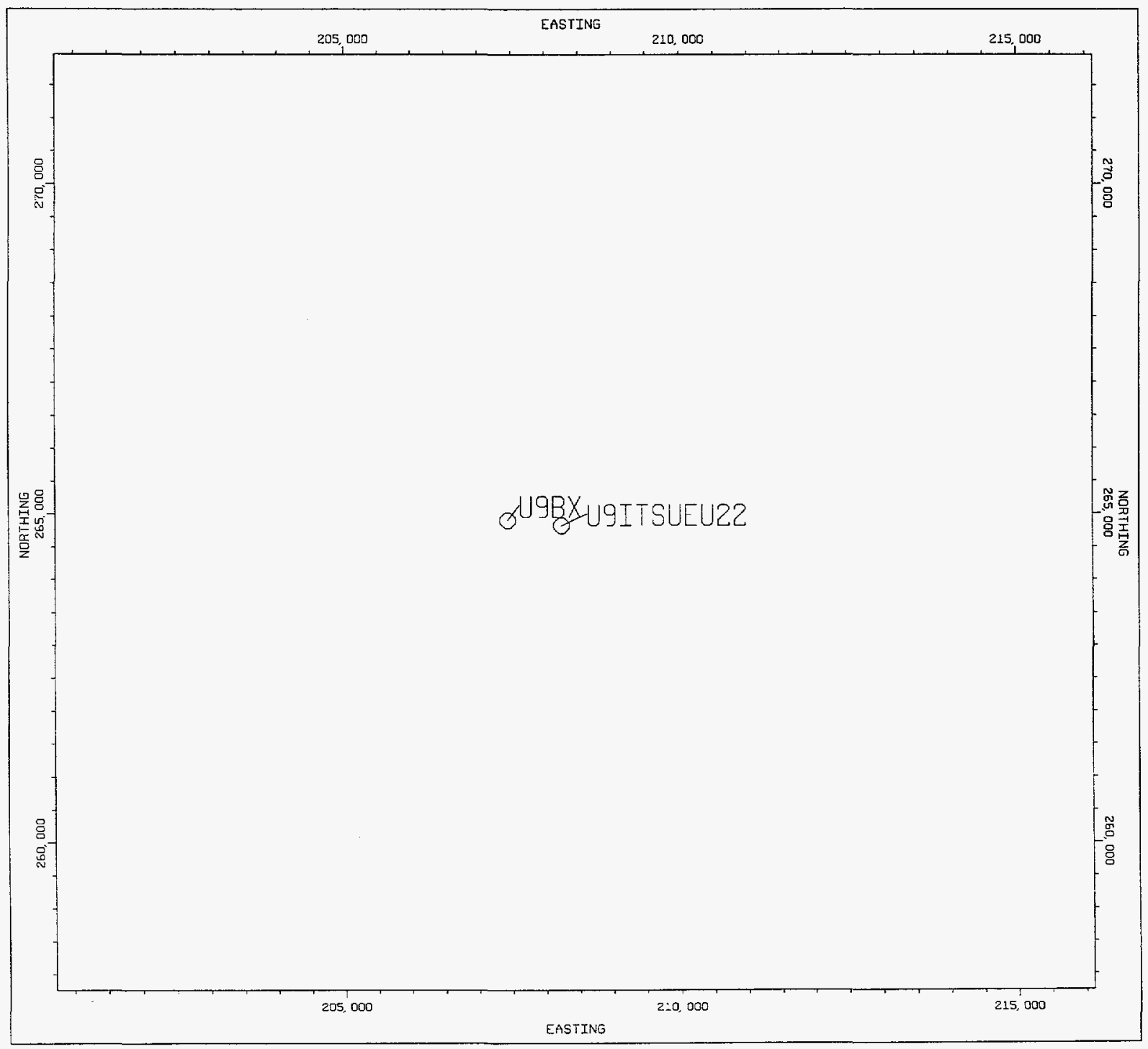

Figure 35. Map showing relative location of U-9bx and U-9 ITS UE-U-22. 


\section{Well Construction}

Well U-9 ITS UE-U-22 (Figure 36) was drilled in 1971 as an exploratory well to a total depth of $553.8 \mathrm{~m}$ below land surface. Land surface elevation at the drill site is $1287.1 \mathrm{~m}$ MSL. During construction, $50.8-\mathrm{cm}$-diameter casing was set in the well to a depth of $12.7 \mathrm{~m}$. The annular space between this casing and the wellbore was cemented to the surface within the well. Below this casing, 44.4-cm-diameter hole was drilled to a total depth. Conventional drilling with air-foam circulation was used to a depth of $122 \mathrm{~m}$. After installation of the casing, drilling of the hole was completed using a vacuum drilling string.

Severe problems with hole erosion (collapse of the wellbore) were encountered during construction of U-9 ITS UE-U-22. Drilling reports and caliper logs indicate hole erosion, primarily between the depths of 122 to $162 \mathrm{~m}$, to a depth of approximately $396 \mathrm{~m}$. Below 396 $\mathrm{m}$, the caliper logs indicate good quality hole.

Although penetration of the water table was not observed during drilling, units of the Tertiary confining unit present at the base of the borehole may be saturated, but of such low transmissivity that the small amounts of fluid produced during the drilling process would not have been noticed. Following completion of drilling at U-9 ITS UE-U-22, the wellbore collapsed, precluding fluid level measurements. On February 28, 1992, DRI, RSN and AWS personnel conducted a total depth check within the well. At that time, a bridge was encountered within the borehole at approximately $158.5 \mathrm{~m}$ below land surface.

During FY95, DRI personnel conducted a site visit to determine wellhead conditions at U-9 ITS UE-U-22. The wellhead consists of approximately $33 \mathrm{~cm}$ of the $91.4-\mathrm{cm}$-diameter surface casing extending above ground level. Approximately $22.9 \mathrm{~cm}$ of the $50.8-\mathrm{cm}$-diameter casing extends above ground level inside the surface casing. As far as could be visually observed, fill material was not present in the annular space between the two casings. The well is capped with a large, circular steel plate set loosely atop the larger casing. A cap is not present for the smaller casing.

\section{Discussion/Recommendations}

In the past, well U-9 ITS UE-U-22 has been considered for recompletion as a monitoring well by the DOE ER program. However, recompletion was not considered possible given the serious hole stability problems associated with the well.

The well was originally completed to a total depth, which should be near, or penetrate, the water table. In addition, Paleozoic units should be present within $100 \mathrm{~m}$ or less of the current total depth. U-9 ITS UE-U-22 could serve as a valuable monitoring well even though the well is not located directly downgradient from the tests conducted in emplacement hole U-9bx. U-9 ITS UE-U-22 is located in a portion of Yucca Flat where groundwater monitoring locations are not currently available. Additionally, the current completion of U-9 ITS UE-U-22, with the relatively large-diameter casing cemented within the wellbore and depth of existing borehole, 


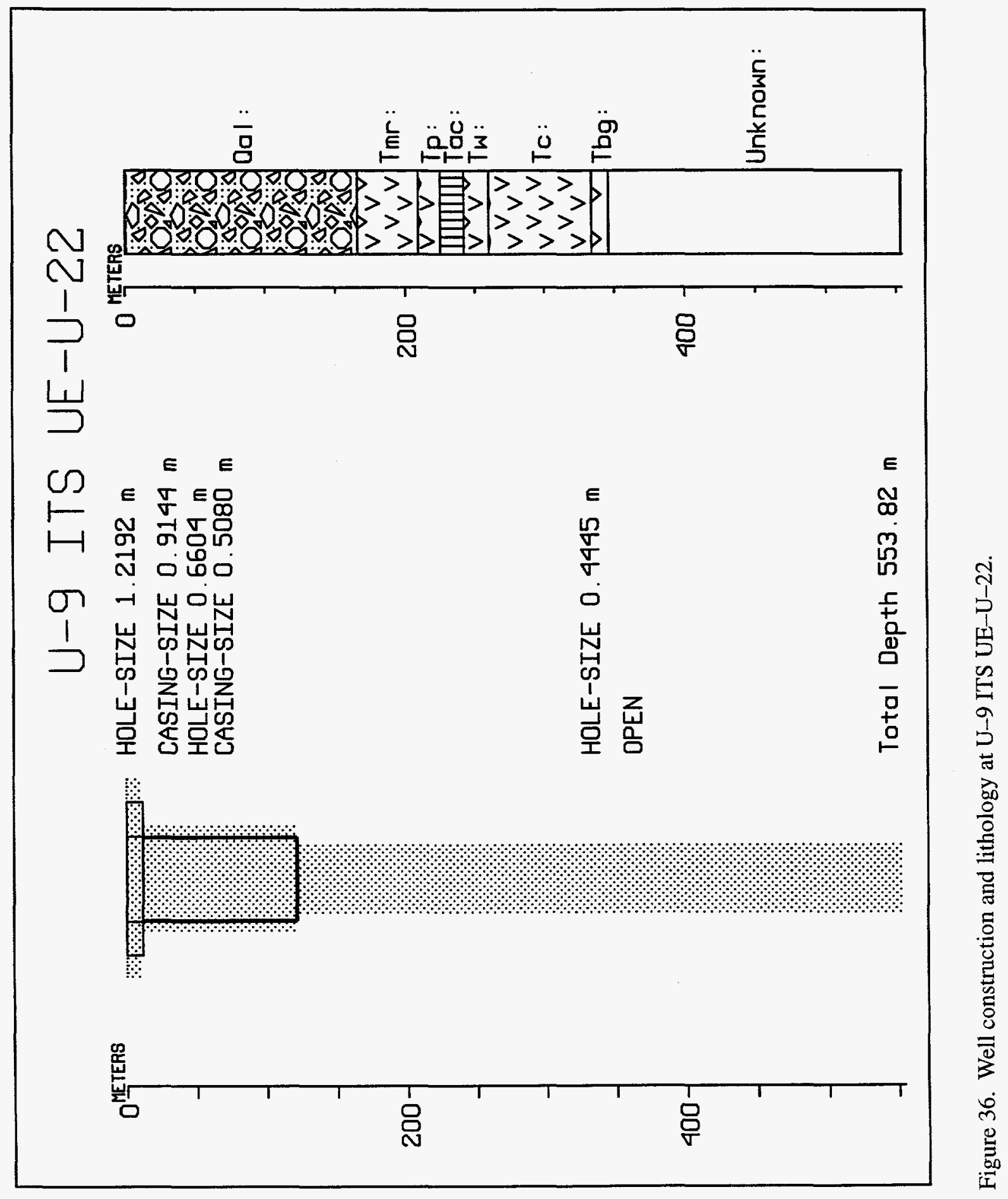


would greatly facilitate the deepening and recompletion of the well as a groundwater quality monitoring location.

To recomplete U-9 ITS UE-U-22 as a groundwater monitoring location a string of 34-cm-diameter casing could be cemented to the surface within the well following cleaning of bridges and fill from the wellbore and deepening of the well into the Paleozoic interval. This would stabilize the wellbore above the Paleozoic interval and isolate the Tertiary and Paleozoic intervals penetrated by the well. Following installation of this casing, the borehole would be deepened until the interval(s) of hydrologic interest is encountered. The well would then be completed with gravel pack and slotted casing over the interval(s) of interest. The installation of a Moyno pump and monitoring line within the recompleted well would facilitate sampling and water-level measurements.

Until action can be taken to recomplete the well, the wellhead at U-9 TTS UE-U-22 should be rehabilitated to prevent contamination of the well. Alternatively, if recompletion of the well is considered not possible due to hole stability, the well should be plugged and abandoned.

\section{RNM \#1, RNM \#2, and RNM \#2S}

One underground nuclear test (U-5e) was conducted near (within $25 \mathrm{~m}$ ) or below the water table within one kilometer of wells RNM \#1, RNM \#2, and RNM \#2S (Figure 37). RNM \#1 was originally constructed as a postshot hole for the event conducted in emplacement hole U-5e. RNM \#1 was recompleted and RNM \#2 and RNM \#2S were constructed to investigate radionuclide migration in the saturated alluvium in which the test at U-5e was conducted. RNM \#2S was constructed as a replacement for RNM \#2, which could not be successfully completed due to repeated collapse of the borehole. RNM \#1 and RNM \#2S are located approximately 123 $\mathrm{m}$ north and $67 \mathrm{~m}$ south, respectively, of U-5e. RNM \#2 is located approximately $91 \mathrm{~m}$ southeast of U-5e. All three wells penetrate only alluvial sediments. Potentiometric data (Winograd and Thordarson, 1975) indicate the groundwater table in this area of the NTS to be essentially flat, however, the general direction of groundwater flow in this area would appear be from the north towards the south. The drilling, construction, hydrologic testing, and radiological sampling conducted during and following construction of RNM\#1, RNM \#2, and RNM \#2S are described in detail in Hoffman et al. (1977).

\section{Well Construction}

\section{RNM \#I}

RNM \#1 (formally postshot hole U-5e PS \#1ASS) consists of a 38.1-cm-diameter hole drilled to a depth of $36.6 \mathrm{~m}$, where $27.3-\mathrm{cm}$-diameter casing was placed in the hole to a depth of $34.1 \mathrm{~m}$ and cemented to the surface (Figure 38). Below this surface casing, 25.1-cm-diameter hole was drilled, using mud to circulate cuttings from the hole, to a depth of $384 \mathrm{~m}$. Casing, 13.97 $\mathrm{cm}$ in diameter, was then placed in the hole to a depth of $383.7 \mathrm{~m}$ and cemented in place over the bottom several meters; however, the remainder of the annular space between the casing and the wellbore was not cemented to the surface. Below this intermediate casing, 12.1-cm-diameter 


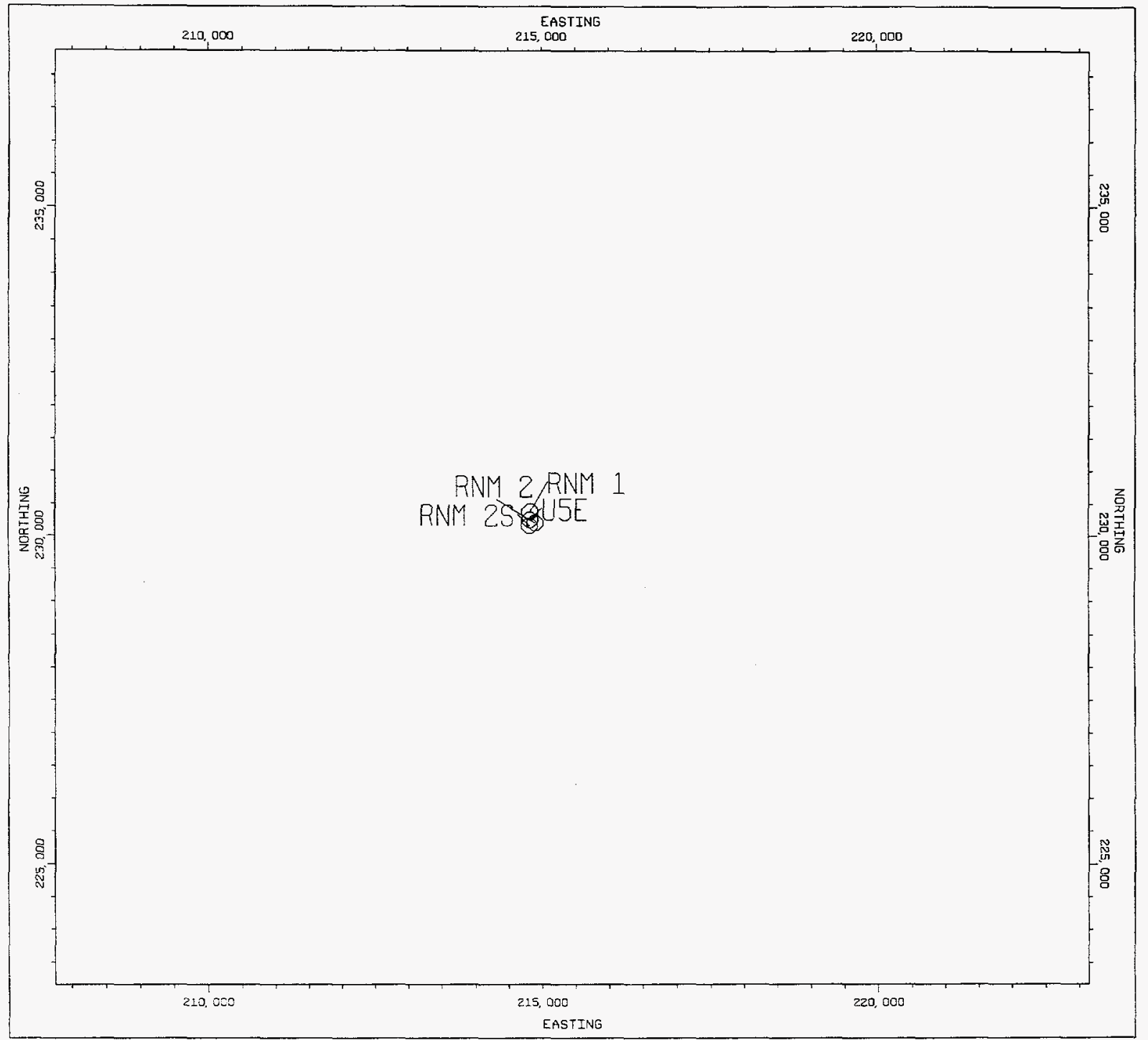

Figure 37. Map showing relative location of U-5e, RNM \#1, RNM \#2 and RNM \#2S. 


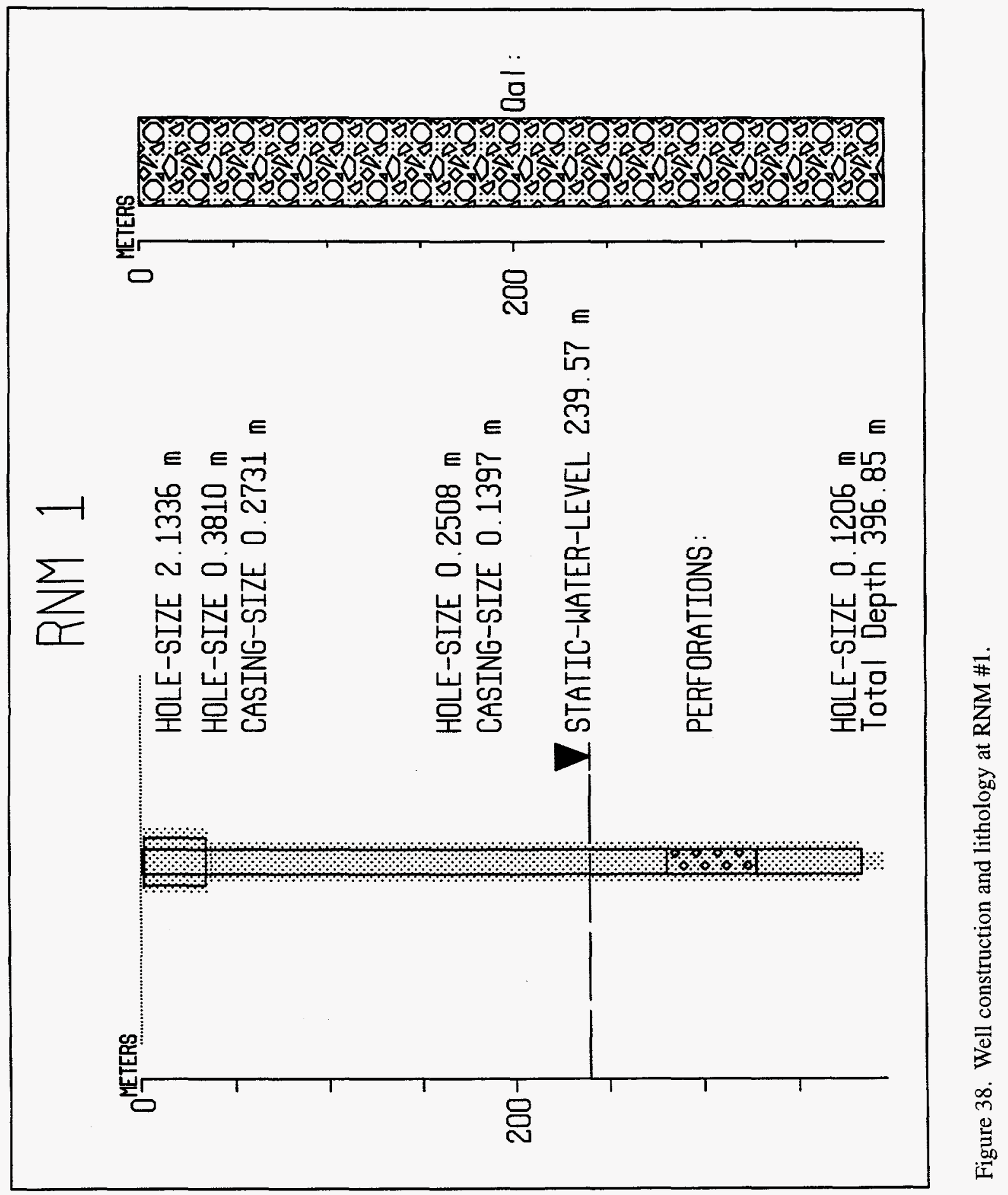


hole was drilled to a total depth of $396.8 \mathrm{~m}$ using air foam. Following construction of the wellbore, the $13.97-\mathrm{cm}$-diameter casing was perforated at various intervals between 280.1 and $327.7 \mathrm{~m}$ below ground level. Plugs were then set in the 13.97-cm-diameter casing at 289.2, $304.5,319.4$, and $373.4 \mathrm{~m}$. Subsequently, the uppermost plug was pushed down the hole to just above the plug at $304.5 \mathrm{~m}$. Last measured total depth of the well was approximately $302.4 \mathrm{~m}$. Surface elevation at the site is $956.0 \mathrm{~m}$ MSL. Reported depth to water in the well is $239.6 \mathrm{~m}$, however, RNM \#1 was drilled down and to the south with an average inclination of approximately 21 degrees from vertical. Vertical depth to the water table is approximately 221 m.

The wellhead at RNM \#1 is located inside of a 2.1 by $1.5-\mathrm{m}$ steel-lined cellar. The bottom of the cellar is approximately $1.2 \mathrm{~m}$ below ground surface. The $13.97-\mathrm{cm}$-diameter casing extends approximately $0.6 \mathrm{~m}$ above the bottom of the cellar. A submersible pump is set within the well on $6.0-\mathrm{cm}$-diameter tubing. The tubing is landed on top of the casing. The tubing extends above the casing to approximately ground level. A steel transducer cable is present between the tubing and the casing.

$R N M \# 2$

RNM \#2 (Figure 39) was drilled as a "Hydrologic Test Hole" in 1974 using air foam with conventional circulation. A 91.4-cm-diameter hole was drilled to $36.0 \mathrm{~m}$, and 50.8 -cm-diameter casing was set in the hole to a depth of $35.7 \mathrm{~m}$. The annular space between this casing and the wellbore was cemented to the surface. A 44.4-cm-diameter bit was used to drill from below the 50.8 -cm-diameter casing to a total depth of $285.0 \mathrm{~m}$. Due to excessive caving of the borehole, $7.3-\mathrm{cm}$-diameter tubing was run in the borehole and washed down through the fill to a depth of $251.5 \mathrm{~m}$. This tubing was perforated from 219.5 to $249.9 \mathrm{~m}$ below land surface. Depth to static water level was reported to be $220.4 \mathrm{~m}$. Surface elevation at the site is $954.5 \mathrm{~m}$.

The wellhead at RNM \#2 consists of approximately $15 \mathrm{~cm}$ of the $50.8-\mathrm{cm}$-diameter casing extending above ground level. The uncapped 7.3-cm-diameter tubing extends approximately 70 $\mathrm{cm}$ above the casing and is landed on two timbers set over the open top of the casing.

$R N M \# 2 S$

RNM \#2S (Figure 40) was drilled prior to the recompletion of U-5e PS \#1ASS (RNM \#1) in 1974 as a replacement for well RNM \#2. A 91.4-cm-diameter hole was drilled to a depth of $36.0 \mathrm{~m}$, using conventional circulation with drilling mud. Casing, $50.8 \mathrm{~cm}$ in diameter, was placed in the borehole and the annular space was cemented to the surface. Below the 50.8-cm-diameter casing, 44.4-cm-diameter hole was drilled to a total depth of $352.3 \mathrm{~m}$ using dual-reverse circulation of air and mud. A string of $24.4-\mathrm{cm}$-diameter casing, containing slots from 316.4 to $341.1 \mathrm{~m}$, was placed in the borehole from the surface to a depth of $341.4 \mathrm{~m}$. This casing was not cemented within the borehole. Two strings of $4.38-\mathrm{cm}$-diameter tubing were welded to the outside of the 24.4-cm-diameter casing. One tubing string ran from the surface to $316.4 \mathrm{~m}$; the second from the surface to $290.8 \mathrm{~m}$. The annulus between the casing and the 


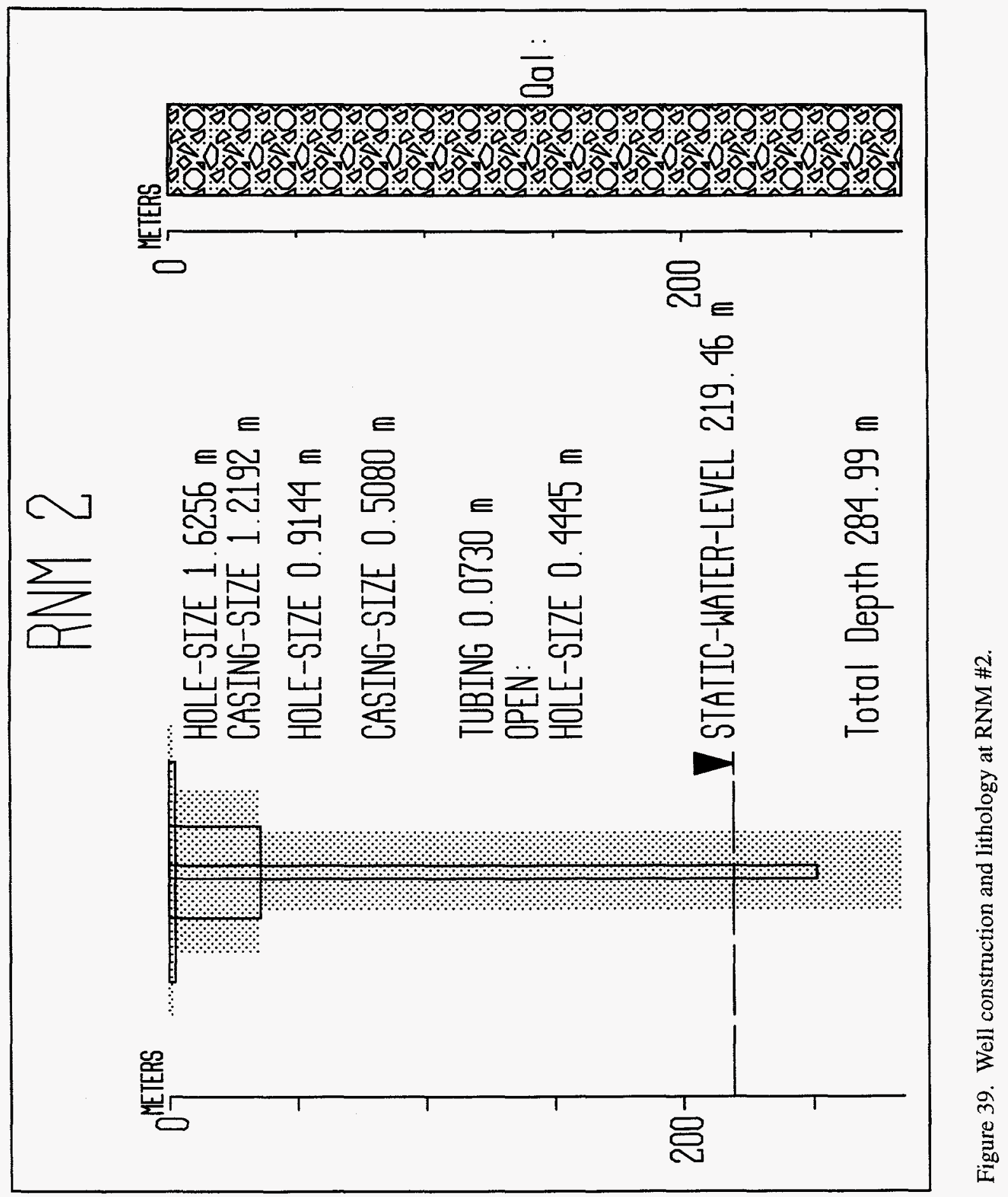




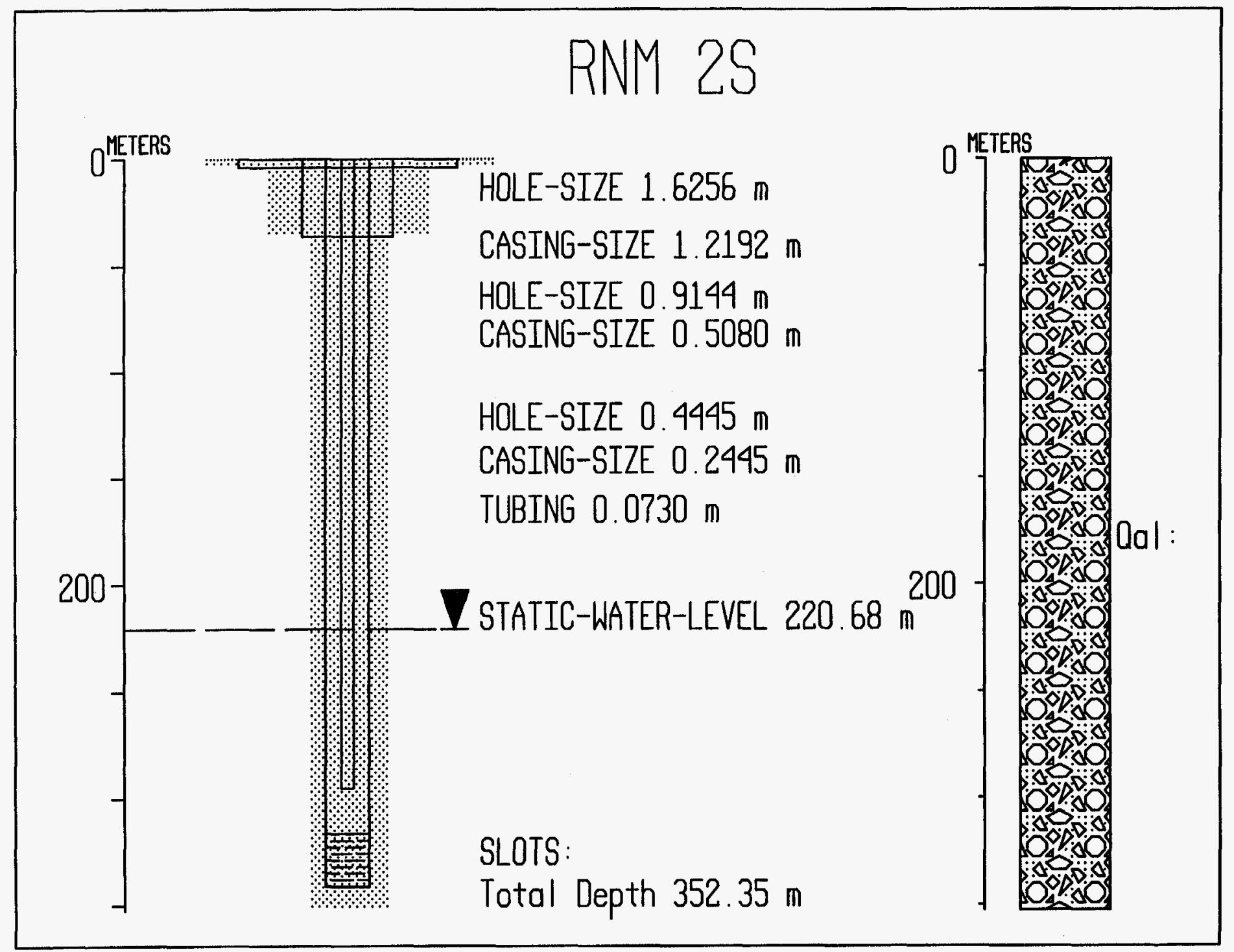

Figure 40. Well construction and lithology at RNM \#2S. 
borehole was gravel packed from 210.3 to $341.4 \mathrm{~m}$. Land surface elevation at the site is estimated at $954.9 \mathrm{~m} \mathrm{MSL}$. Depth to static water level in the well is similar to that at RNM \#1 and RNM \#2, approximately $221 \mathrm{~m}$ below land surface.

The wellhead at RNM \#2S consists of approximately $35 \mathrm{~cm}$ of the 50.8 -cm-diameter casing extending above ground level. Two holes approximately $10 \mathrm{~cm}$ in diameter were cut in the casing near ground level. The 24.4-cm-diameter slotted casing is landed on a steel plate set atop the $50.8-\mathrm{cm}$-diameter casing. A submersible pump, set on 11.43 -cm-diameter tubing, is in place within the well at a depth of $316.1 \mathrm{~m}$. In addition to the pump tubing, $6.0-\mathrm{cm}$-diameter tubing was placed in the annular space between the well casing and pump tubing to a depth of $295.35 \mathrm{~m}$.

\section{Discussion/Recommendations}

The Cambric site has been the location of extensive investigation into the transport of radionuclides produced by underground testing and could provide additional information in the future if sampled on a regular basis. It is the only location on the NTS with three wells in such close proximity. Two of these wells are capable of producing fluid at rates which result in measurable drawdown in the other two wells. Aquifer testing, utilizing updated data acquisition and groundwater flow modeling techniques not available just a few years ago, could yield valuable information on spacial variations in transmissivity within the alluvial aquifer in Frenchman Flat.

As currently constructed, all three wellheads pose serious risks for contamination of the wells by surface water, or other materials. These wellheads should be rehabilitated in compliance with EPA guidelines and Nevada state regulations.

\section{Test Well \#7}

Six underground nuclear tests (U-3dn, U-6ai, U-7k, U-3an, U-3bs, and U-3jn) were conducted near (within $50 \mathrm{~m}$ ) or below the water table within one kilometer of Test Well \#7 (TW7) (Figure 41). Potentiometric data (Winograd and Thordarson, 1975) indicate the general direction of groundwater flow in this area of the NTS to be from the northwest towards the southeast.

\section{Well Construction}

Test Well \#7 (Figure 42) was drilled in 1954 to a total depth of $692.5 \mathrm{~m}$ below land surface. Ground elevation at the drill site is approximately $1237.2 \mathrm{~m}$ MSL. No records of the drilling technique or circulating medium could be found. A $38.1-\mathrm{cm}$-diameter borehole was drilled to a depth of $613.9 \mathrm{~m}$, where $29.8-\mathrm{cm}$-diameter casing was set from the surface to $613.9 \mathrm{~m}$. It is not known whether this casing was cemented within the wellbore. Below this casing, 27-cm-diameter hole was drilled to total depth. A 24.4-cm-diameter liner casing was placed within the hole from a depth of $602.6 \mathrm{~m}$ to total depth at $692.5 \mathrm{~m}$. It is not known whether this liner was cemented within the well. The liner was perforated at various intervals between 582.2 $\mathrm{m}$ and $686.1 \mathrm{~m}$. The reported depth to water within the well is $508.4 \mathrm{~m}$. 


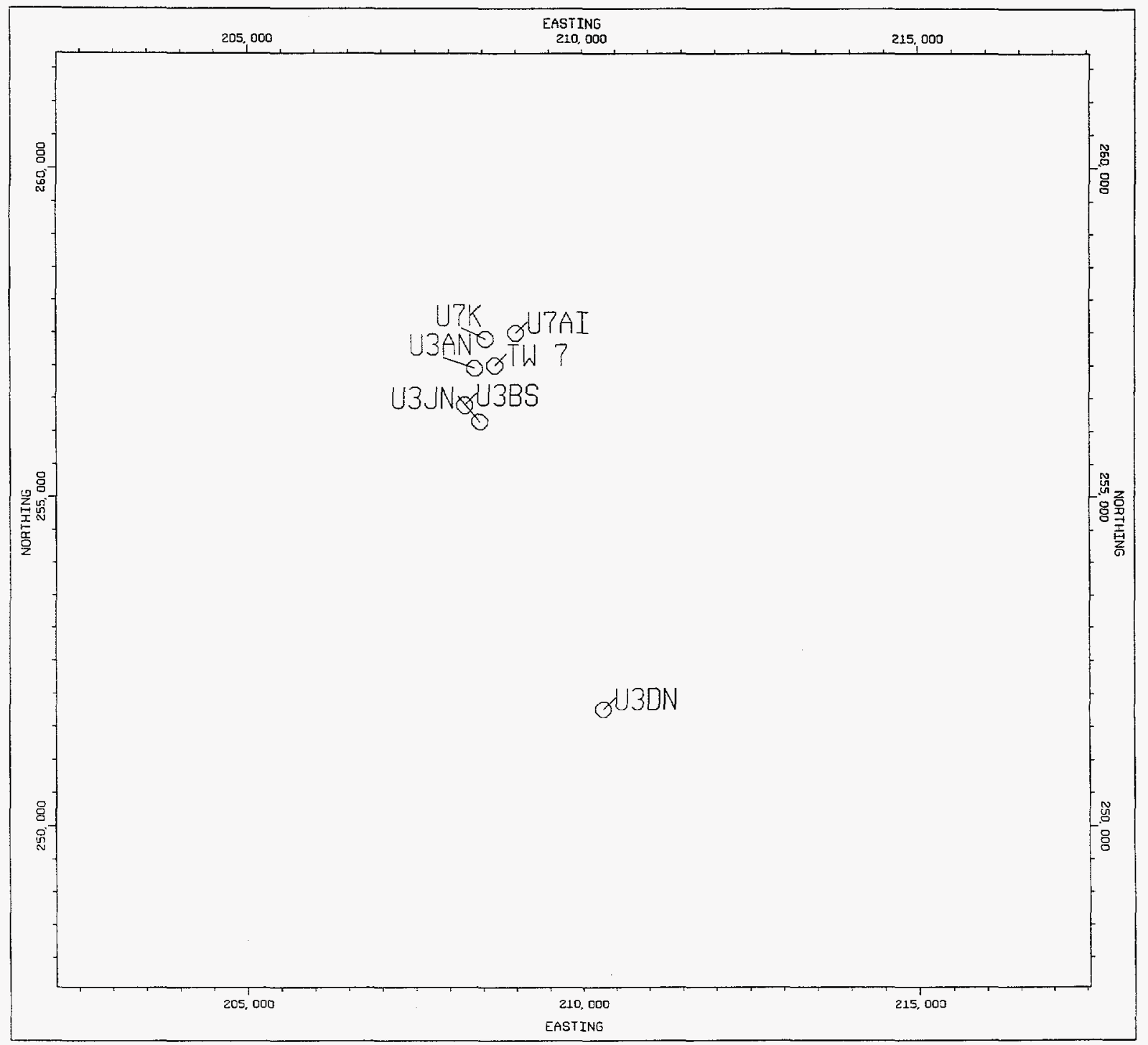

Figure 41. Map showing relative location of TW7, U-7k, U-3dn, U-6ai, U-3an, U-3bs and U-3jn. 


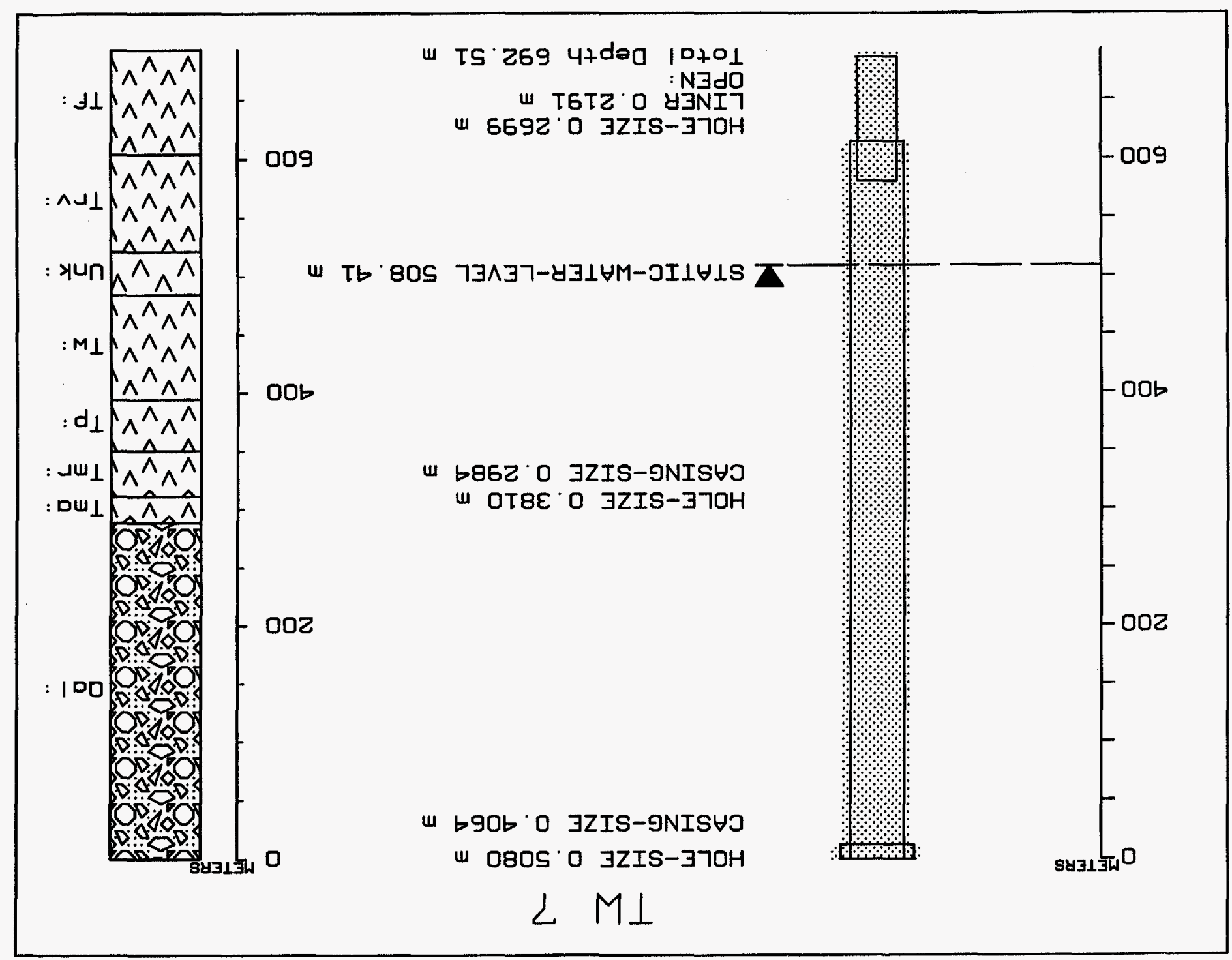


The wellhead at Test Well \#7 consists of approximately $1 \mathrm{~m}$ of the $40.1-\mathrm{cm}$-diameter surface casing extending above ground level, with the 29.8 -cm-diameter intermediate casing extending approximately $30 \mathrm{~cm}$ above the top of the surface casing. The two casings are joined by a flat steel plate welded to the inside of the surface casing and the outside of the intermediate casing. The surface casing is surrounded by a 55-gallon drum with the space between the drum and the surface casing filled with cement. The wellhead is surrounded by an approximately 6 by $6 \mathrm{~m}$ concrete pad. The 29.8-cm-diameter intermediate casing is topped with a heavy steel flange. The flange is covered with a hinged, heavy, flat steel plate.

During FY95, DRI personnel conducted total depth/fluid check, temperature, electrical conductivity, $\mathrm{pH}$ and caliper logs within Test Well \#7. Fluid level was measured within the well at $499.6 \mathrm{~m}$ below ground level. Total depth was measured at $602.6 \mathrm{~m}$ below ground level, however, this depth corresponds closely with the recorded depth of the liner top within the well. The total depth measured most likely resulted from the logging tools hanging up on the liner top, and additional open hole may be present below this depth. Temperature, electrical conductivity and $\mathrm{pH}$ logs did not indicate vertical fluid movement within the portion of the well between 499.6 and $602.6 \mathrm{~m}$. The caliper log did indicate a short section of constricted hole diameter at approximately $475.8 \mathrm{~m}$. At this depth, hole size was reduced from 29.8 -cm-diameter to a diameter of approximately $16.7 \mathrm{~cm}$.

\section{Discussion/Recommendations}

Due to the construction and age of the well, it is unlikely that Test Well \#7 could be successfully recompleted as an NTS groundwater quality monitoring location. Additionally, Test Well \#7 is completed within units of the Tertiary tuff confining interval and it is unlikely that the well is capable of producing sufficient quantities of fluid to be purged and sampled by pumping. However, Test Well \#7 is located downgradient from the underground test conducted at $\mathrm{U}-7 \mathrm{k}$, which was detonated at a depth of $48 \mathrm{~m}$ below the water table, and in an area where numerous underground tests have been conducted near or below the water table and may provide valuable information on radionuclide transport in the Tertiary interval if sampled by bailer on a regular basis.

The wellhead at Test Well \#7 should be rehabilitated in compliance with EPA guidelines and Nevada state regulations.

\section{Test Hole \#1, Test Hole \#5, and Test Hole \#6}

One underground nuclear test (U-3jq) was conducted near (within $50 \mathrm{~m}$ ) or below the water table within one kilometer of wells Test Hole \#1, Test Hole \#5, and Test Hole \#6 (Figure 43). These boreholes are part of a grid pattern of nine wells (Test Holes \#1 through \#9) drilled in Yucca Flat in the early 1960s as geological exploration holes in support of underground testing activities. These boreholes are located approximately $0.8 \mathrm{~km}$ southeast of the underground test conducted in emplacement hole U-3jq, and are located to the north, south, east and west of Hydrologic Test Hole-E (HTH-E), which is listed as having been destroyed in September 1963. 


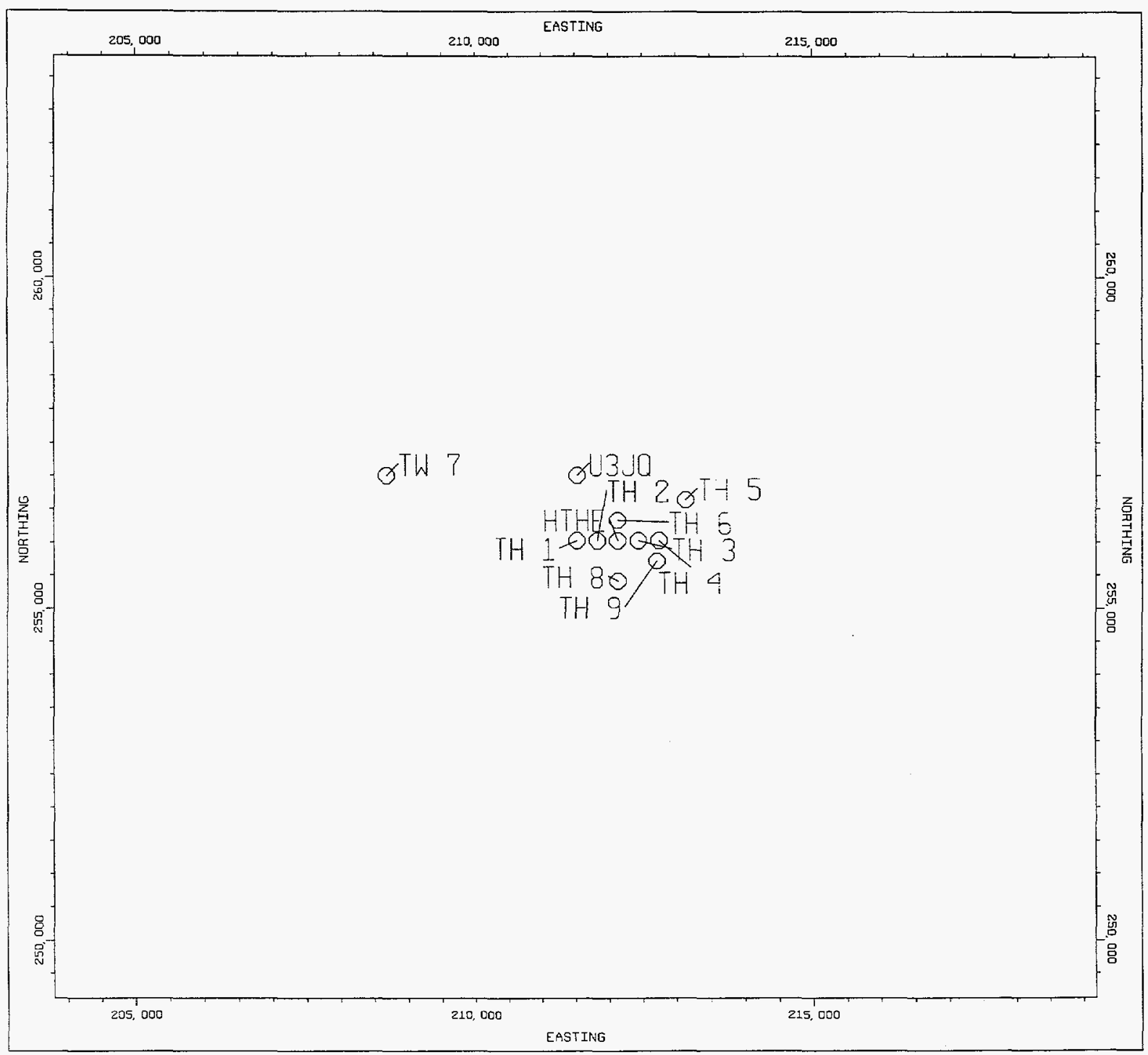

Figure 43. Map showing relative location of Test Hole \#1 through Test Hole \#9, HTH-E and U-3jq. 
Potentiometric data (Winograd and Thordarson, 1975) indicate the general direction of groundwater flow in this area of the NTS to be from the northeast towards the southwest.

Test Hole \#4 and Test Hole \#9 are listed as plugged with cement to the surface.

\section{Well Construction}

These test holes range in depth from 145.4 to $198.1 \mathrm{~m}$. All have 27.3-cm-diameter casing, set to depths of approximately $24.4 \mathrm{~m}$ and cemented in place to the surface. Due to their shallow total depth, none of the boreholes intersected the water table. All penetrated Tertiary volcanic units at their total depths.

During field examination of the wellheads at Test Hole \#1, Test Hole \#5, and Test Hole \#6, all were found to be capped with steel plates welded to the $27.3-\mathrm{cm}$-diameter casing that extends above ground level at various heights. These welded steel plates are typical of boreholes at the NTS that have been stemmed with sand in preparation for nearby underground testing.

\section{Discussion/Recommendations}

Due to the presence of existing surface casing, and relative locations, these boreholes would be ideal candidates for recompletion, if it can be shown that the stemming material can be removed. Recompletion would consist of the removal of the steel caps and stemming material, and deepening of the boreholes into the Paleozoic carbonate aquifer. These boreholes would then be completed with gravel-packed slotted tubing over the interval(s) of interest as determined by geophysical logging and hydrologic testing. Owing to their relative locations, these wells would provide valuable information concerning spacial variations in transmissivity of the carbonate aquifer.

If not selected for recompletion, the stemming material should be determined and the holes properly plugged and abandoned in compliance with Nevada state regulations. Owing to the borehole did not penetrate the water table, this would most likely involve only the removal of the stemming material to a depth of $15.25 \mathrm{~m}$ and plugging of the upper $15.25 \mathrm{~m}$ of each borehole with a cement plug.

\section{UE-2a}

\section{Discussion/Recommendations}

Four underground nuclear tests (U-2fa, U-2dr, U-2dg, and U-2fd) were conducted near (within $25 \mathrm{~m}$ ) or below the water table within one kilometer of well UE-2a. However, during construction of UE-2a, at a total depth of $190.8 \mathrm{~m}$, the drill string became stuck in the hole and subsequently twisted off and $89.5 \mathrm{~m}$ of drill string was lost in the hole. The top of this drill string is at approximately $100 \mathrm{~m}$ below land surface. Prior to losing the drill string, 50.8-cm-diameter casing was cemented within the well to a depth of $23.8 \mathrm{~m}$.

The wellhead at UE-2a consists of approximately $10 \mathrm{~cm}$ of 50.8 -cm-diameter casing extending above ground level. This casing was set at a depth of $23.8 \mathrm{~m}$ and the annulus between 
the casing and the borehole cemented to the surface. To prevent shortcutting of surface water or other material to the shallow unsaturated zone, UE-2a should be plugged and abandoned in accordance with current DOE NTS procedures and Nevada state regulations and the well removed from the NTS open borehole inventory.

\section{U-15k Test Hole, UE-15h, UE-15g, UE-15f, and U-15b Exploration Hole \#1}

U-15k Test Hole, UE-15h, UE-15g, UE-15f, and U-15b Exploration Hole \#1 are located within the Climax Stock, a granitic igneous intrusion exposed at the surface in extreme northern Yucca Flat. One underground nuclear test, U-15a, was conducted near (within $25 \mathrm{~m}$ ) or below the water table within one kilometer of wells U-15k Test Hole, UE-15h, UE-15g, UE-15f, and $\mathrm{U}-15 \mathrm{~b}$ (Figure 44).

\section{Well Construction}

\section{$U-15 k$ Test Hole}

U-15k Test Hole (Figure 45) consists of 14-cm-diameter casing cemented within a 22.2-cm-diameter borehole to a depth of $123.1 \mathrm{~m}$. Below this casing, 12.1-cm-diameter hole was drilled to a reported total depth of $261.2 \mathrm{~m}$. Reported depth to fluid level was $218.5 \mathrm{~m}$. It is unknown whether this fluid level represents perched water, the groundwater table, or is the result of fluid left in the hole following construction of the borehole.

DRI personnel visited the site in 1995 and measured total depth of the well at $260.3 \mathrm{~m}$, with static water level of $196.6 \mathrm{~m}$ below land surface. The wellhead at U-15k Test Hole consists of the 14-cm-diameter casing cut off approximately $5 \mathrm{~cm}$ below ground level. A short section of steel I-beam is in place over the cut-off casing as a cap for the well.

$U E-15 h, U E-15 g, U E-15 f$

UE-15h, UE-15g, UE-15f were drilled as geological exploration holes using a slant rig to drill directional holes. All three holes were continuously cored, using 8.9- or 7.6-cm-diameter NX core tools from approximately $18.3 \mathrm{~m}$ to total depth. Measured total depths for UE-15h, UE-15g, UE-15f are $184.7,200$, and $199 \mathrm{~m}$, respectively.

During field investigation of the three wells, it was determined that UE-15g and UE-15f have been filled with cement to the surface. UE-15h could not be located in the field.

\section{U-15b Exploration Hole \#1}

U-15b Exploration Hole \#1 was drilled in 1961 to a total depth of $548.6 \mathrm{~m}$ (Figure 46). Surface casing, $21.9 \mathrm{~cm}$ in diameter, was placed in the borehole to a depth of $4.6 \mathrm{~m}$. Below this casing, 6.1-cm-diameter borehole was drilled to total depth. Static water level was not recorded for the completed borehole.

Records indicate this hole is bridged at a depth of $27.4 \mathrm{~m}$. Current total depth and fluid level check were not conducted due to road conditions prohibiting access for DRI's logging unit. 


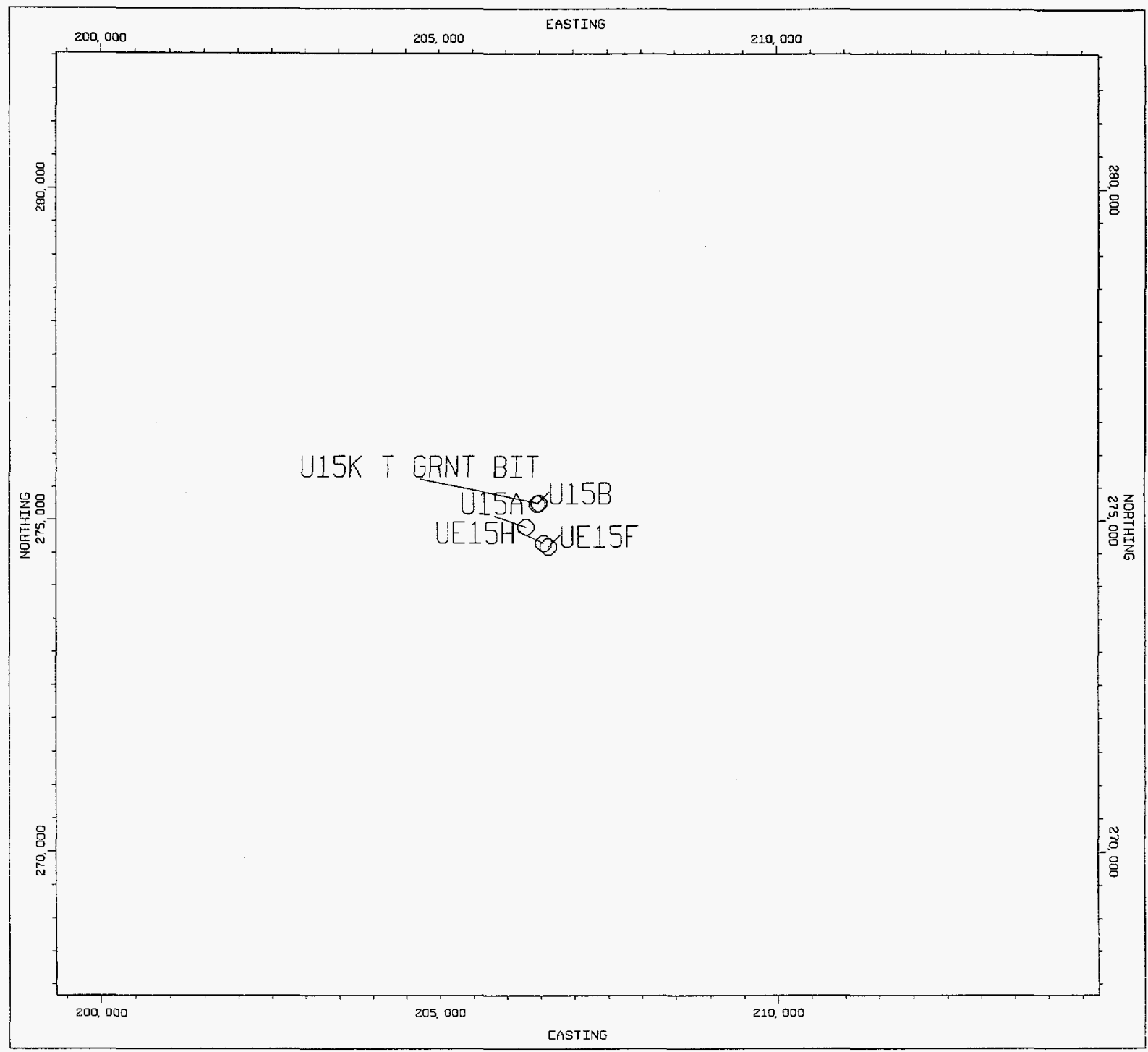

Figure 44. Map showing relative location of U-15k, U-15b, U-15a, UE-15h and UE-15f. 


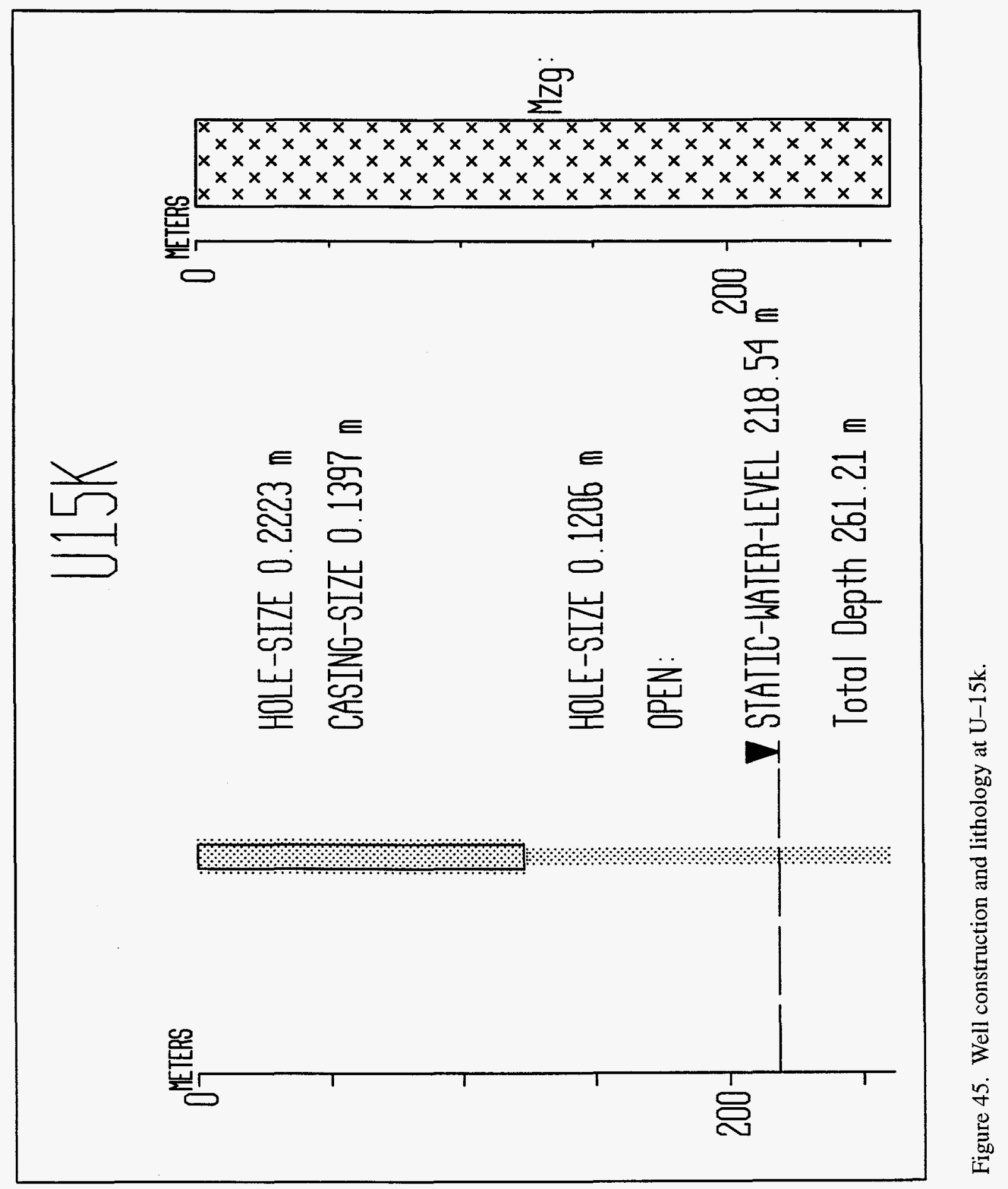




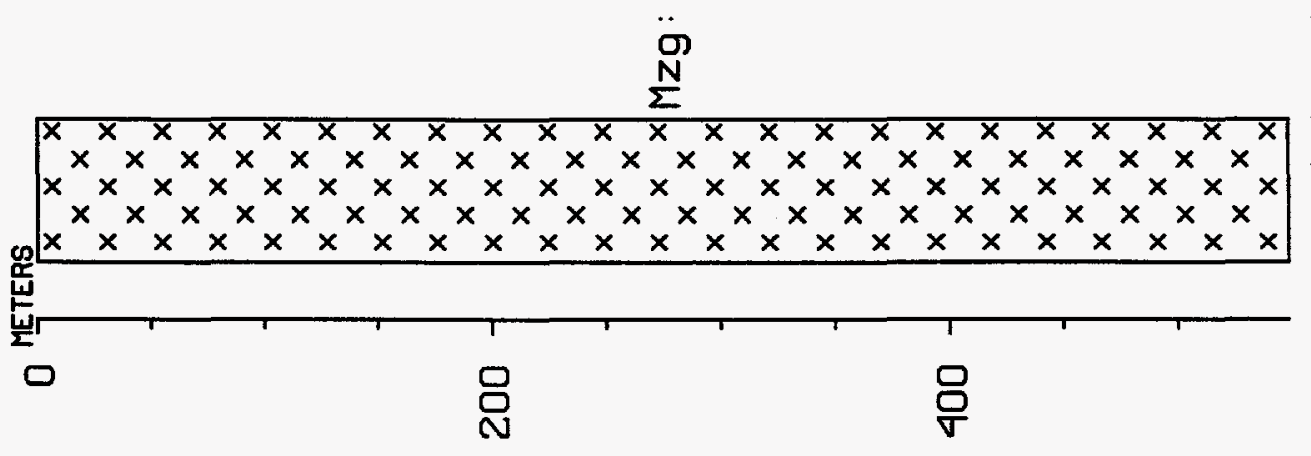

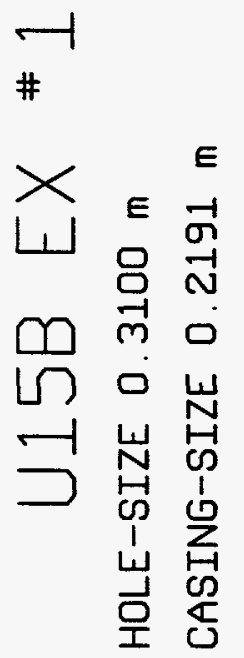

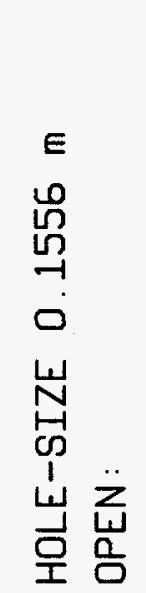

in 


\section{Discussion/Recommendations}

Wells UE-15g and UE- $15 f$ are effectively plugged and abandoned. These wells should be listed as plugged and abandoned, and removed from the NTS open borehole inventory.

Due to the small-diameter casing in place within well U-15k Test Hole, the well would not be an ideal candidate for deepening and recompletion as a groundwater monitoring location. However, the existing casing is of adequate size to permit geophysical logging, hydraulic testing (using a small-diameter Moyno pump and monitoring line), and sampling of the formation fluid. This information would be useful in characterization of the hydrologic properties of the Climax Stock and its role in the hydrogeology of the NTS groundwater system. This investigation would not require the mobilization of a drilling rig (a Moyno pump and monitoring line could be installed with a crane), and could be performed at minimal cost.

Although apparently bridged at approximately $27.4 \mathrm{~m}$ below ground level, U-15b Exploration Hole \#1 reached a total depth of $548.6 \mathrm{~m}$ and likely penetrated the water table or zones of perched water. Because of the relatively large casing set within the wellbore (21.9-cm-diameter), it should be possible to recomplete the well to produce a serviceable groundwater quality monitoring location within the Climax Stock. The well should be cleaned of fill and deepened if needed. Geophysical logs could be conducted to determine zones of interest and the well gravel packed and completed with slotted casing and a monitoring line.

\section{Marble \#1, Marble \#2, and Marble \#3}

Marble \#1, Marble \#2, and Marble \#3 are located within the marblized metamorphic boundary between the Climax Stock, a granitic igneous intrusion exposed at the surface in extreme northern Yucca Flat, and Paleozoic carbonate units. One underground nuclear test, U-15a, was conducted near (within $25 \mathrm{~m}$ ) or below the water table within one kilometer of the Marble \#1, Marble \#2, and Marble \#3 boreholes (Figure 47).

\section{Well Construction}

All three of the Marble boreholes were drilled in 1961 to obtain lithologic cores for geologic exploration. The boreholes are of small diameter, approximately $8 \mathrm{~cm}$, and of shallow depth. Reported total depth for the Marble \#1, Marble \#2, and Marble \#3 boreholes are 115.2, 60 , and $298.1 \mathrm{~m}$, respectively. Marble \#1 and Marble \#3 have reported static water levels of 102.4 and $145.4 \mathrm{~m}$ below land surface.

During field investigations, none of the three boreholes could be located.

\section{Discussion/Recommendations}

These are the only wells located within the metamorphic zone surrounding the Climax Stock, and because two of these wells are reported to have penetrated the water table, further efforts should be made to locate these wells. This may require the use of metal locators, ground penetrating radar, or other methods. 


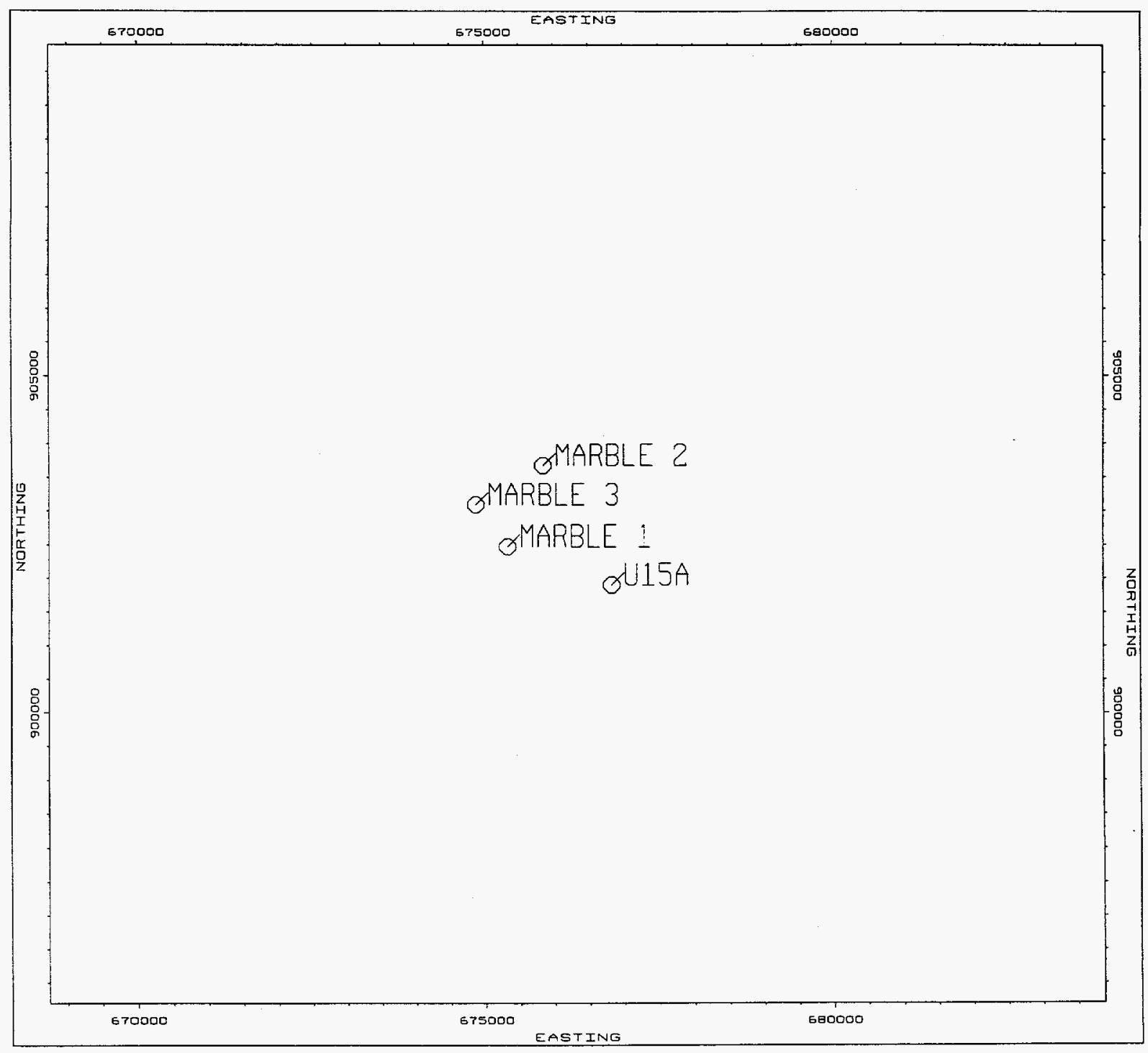

Figure 47. Map showing relative locations of Marble \#1, Marble \#2, Marble \#3, and U-15a. 


\section{Jangle Test Hole \#A4}

One underground nuclear test, U-10k, was conducted near (within $25 \mathrm{~m}$ ) or below the water table within one kilometer of the Jangle Test Hole \#A4 (Figure 48).

Well Construction

Jangle Test Hole \#A4 was drilled in 1952 in northern Yucca Flat. Little information is available concerning this borehole. Total depth is reported as approximately $152 \mathrm{~m}$, however, no information could be found relating to borehole diameter or completion.

Although the general location of the well is recorded (Nevada State Coordinates), an extensive search in the field could not positively identify the well. A round steel fitting approximately $50 \mathrm{~cm}$ in diameter set above a circular conduit composed of masonry bricks was found. This conduit was filled almost to ground level with dirt. Due to the dirt fill, it could not be determined how deep the brick conduit extended below ground level.

\section{Discussion/Recommendations}

It is unlikely that this well could be definitively located. If located, however, it seems unlikely it would be suitable for recompletion. This well should be listed as destroyed or lost and removed from the NTS open borehole inventory.

\section{UE-11a}

One underground nuclear test (U-5i) conducted near or below the water table is located within one kilometer of well UE-11a (Figure 49). Potentiometric data (Winograd and Thordarson, 1975) indicate the general direction of groundwater flow in this area to be from the northwest towards the southeast. Well UE-11a is located $658.5 \mathrm{~m}$ northwest (upgradient) from the test conducted in emplacement hole U-5i. The depth of burial for the event conducted in hole $\mathrm{U}-5 \mathrm{i}$ is listed as $256 \mathrm{~m}$ below land surface, approximately $49 \mathrm{~m}$ above the estimated water table depth of $304.8 \mathrm{~m}$.

\section{Well Construction}

Well UE-11a (Figure 50) was originally drilled in 1965 as an exploratory well in extreme northern Frenchman Flat to a total depth of $426.7 \mathrm{~m}$. Land surface elevation at the well site is approximately $1081.1 \mathrm{~m}$ above mean sea level (MSL). During construction, 27.3-cm-diameter casing was set to a depth of $182.6 \mathrm{~m}$ inside an initial borehole drilled to a depth of $185.9 \mathrm{~m}$. The annular space between this casing and the wellbore was cemented to the surface. Below this casing, a 22.2-cm-diameter hole was drilled to total depth within Tertiary tuff units. The well was drilled using air-foam with conventional circulation. Depth to static water level following construction was measured at $343.8 \mathrm{~m}$. The contact between alluvium and tuff units was penetrated by the wellbore at a depth of $167.6 \mathrm{~m}$. Following construction, sidewall core samples were obtained from selected intervals within the well. In attempting to obtain geophysical logs, 230 barrels of drilling mud were pumped into the hole in an effort to stabilize the wellbore and raise the water level within the well. 


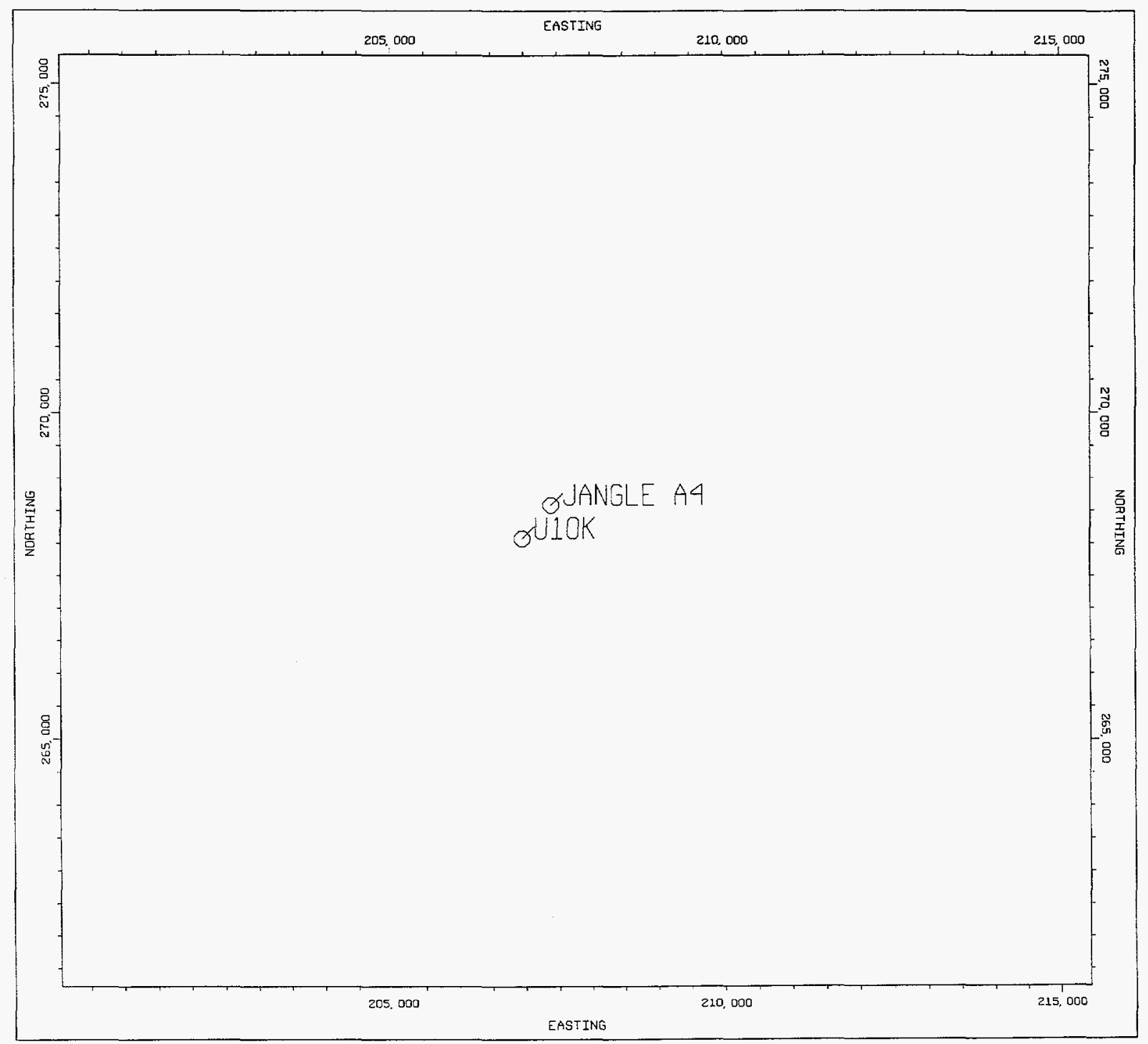

Figure 48. Map showing relative location of U-10k and Jangle A4. 


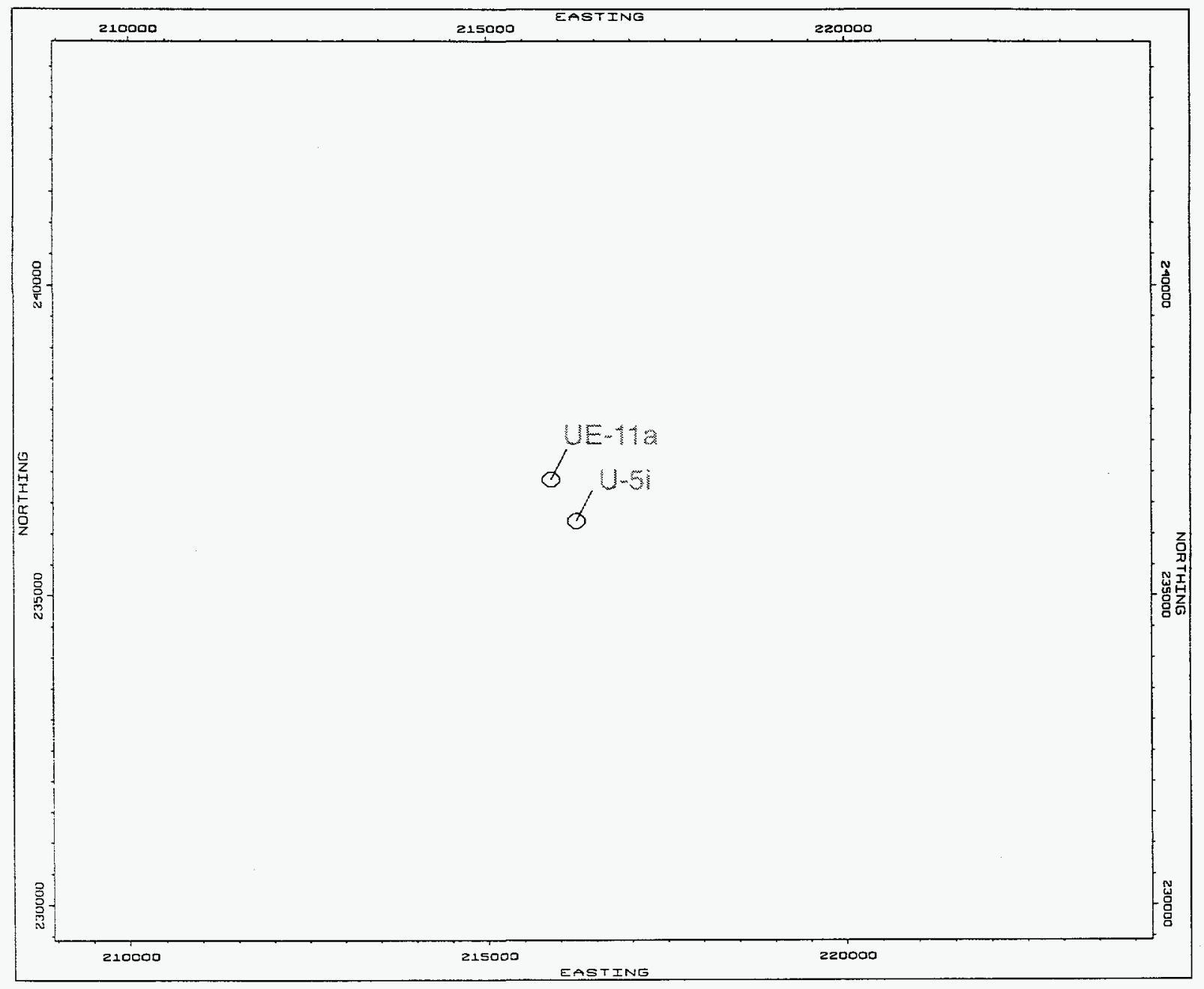

Figure 49. Map showing relative location of UE-11a and U-5i. 


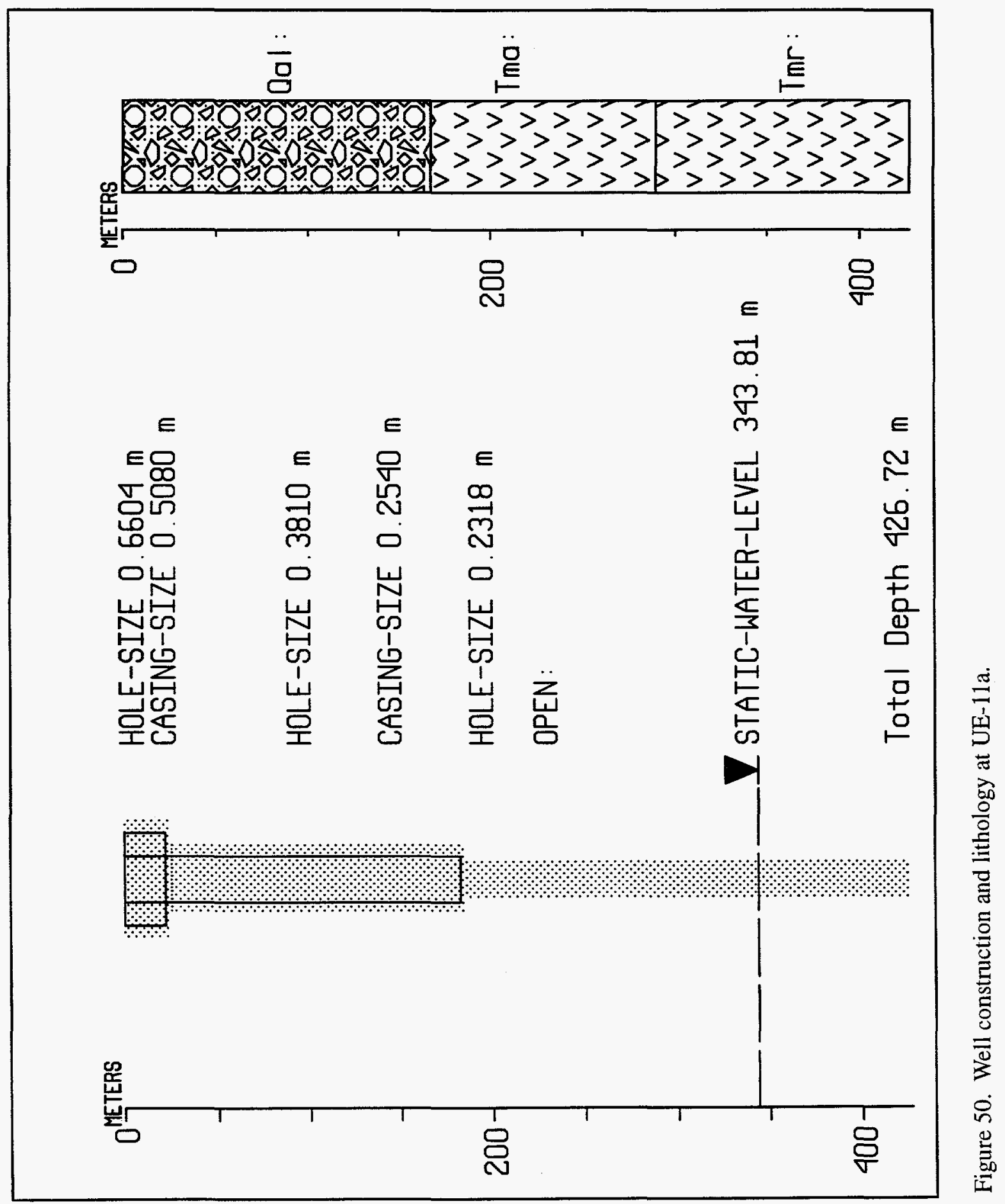


Well UE-11 a was recompleted in 1982. This recompletion work consisted of enlarging the $22.2-\mathrm{cm}$-diameter borehole to $25.1 \mathrm{~cm}$ to total depth at $426.7 \mathrm{~m}$. Following enlargement of the borehole, static water level was measured at $349.6 \mathrm{~m}$ below land surface. Temporary casing, 17.8 $\mathrm{cm}$ in diameter, was then placed in the borehole to total depth, however, this casing was removed 47 days later.

During FY96, DRI personnel conducted a site visit to UE-11a. The wellhead consists of the 27.3-cm-diameter casing cut off at ground level. This casing is covered with a flat steel lid set loosely over the casing. The well site is on a well-defined drill pad overlooking the Area 5 Low-Level Radioactive Waste Management Site.

DRI's logging unit was used to perform a total depth/fluid level check in the well. Fluid level was measured at $343.8 \mathrm{~m}$ below land surface. After working the logging tool past a partial bridge in the wellbore between 345.6 to $346.9 \mathrm{~m}$, total depth was measured in the well at 424.9 $\mathrm{m}$, approximately $1.8 \mathrm{~m}$ above the drilled total depth of the well. Following the initial total depth/fluid level check, attempts were made to obtain temperature, electrical conductivity, $\mathrm{pH}$ and caliper logs within the wellbore. Despite repeated attempts, it was not possible to re-enter the portion of the borehole below the bridged interval. A caliper log was obtained over the open-hole portion of the well from above the bridge to the bottom of the 27.3-cm-diameter casing (Figure 51). The caliper log indicated hole erosion up to $50 \mathrm{~cm}$ between 250 to $300 \mathrm{~m}$ below land surface. The bottom of the $27.3-\mathrm{cm}$-diameter casing was observed at a depth of approximately $185 \mathrm{~m}$.

\section{Discussion/Recommendations}

Although well UE-11a is located upgradient from the underground nuclear test conducted at U-5i, it is located in extreme northern Frenchman Flat, upgradient from underground testing, where groundwater quality monitoring locations are not currently available. Aside from a partial bridge, located just below the static water level in the well, the well appears to be open to within approximately $2 \mathrm{~m}$ of the original drilled total depth. Additionally, the well is currently completed with relatively large-diameter casing $(22.2 \mathrm{~cm})$ to below the contact between the alluvium and tuff units penetrated by the well, and the annular space between this casing and the wellbore is cemented to the surface. The well is also located on a well-defined drill pad, just off a heavily traveled road, and should require minimal effort to obtain the necessary clearances for construction and equipment access.

UE-11 a could be easily recompleted by cleaning the hole of bridges and fill and completing with 14-cm-diameter slotted tubing and a monitoring line. The slotted portion of the tubing would be gravel packed over the Tertiary interval below the water table and cemented to the surface. This 14-cm-diameter tubing would permit the installation of a Moyno pump to purge the well prior to sampling.

The wellhead at UE-11a should be rehabilitated as soon as possible to prevent contamination of the well by surface water or other materials. It is possible the obstruction 


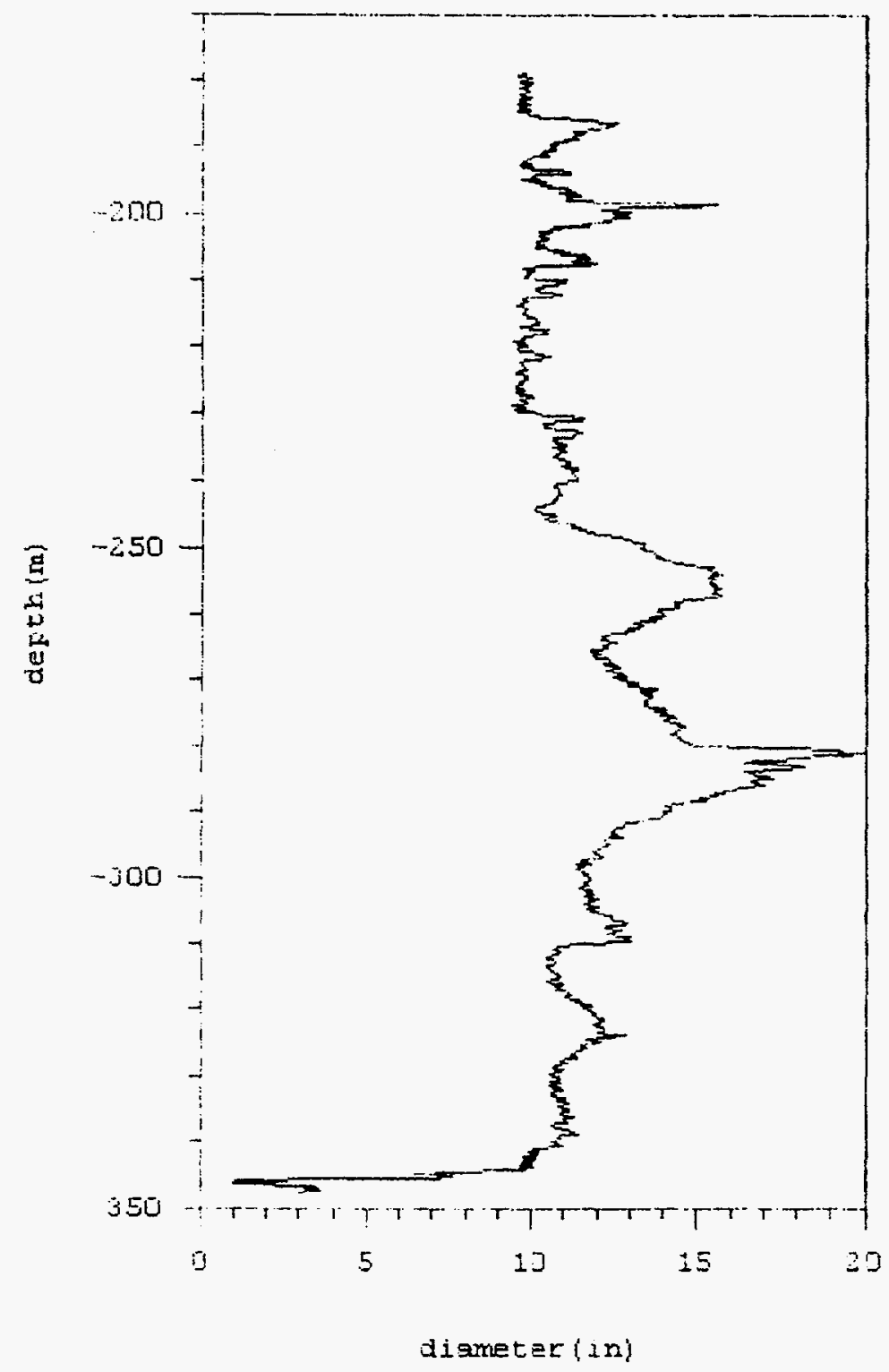

Figure 51. Caliper log UE-11a.

detected just below the water table may be the result of foreign materials dropped into the unsecured well. This rehabilitation would consist primarily of the extension of the casing a minimum of $30 \mathrm{~cm}$ above ground level, installation of a concrete pad and bumper guards around the casing, installation of a water-tight lockable cap, and any other measures required to ensure the prevention of contamination of any portion of the well by surface water or other materials. The requirements applicable for wellhead rehabilitation are given by the EPA in their "Handbook of Suggested Practices for the Design and Installation of Ground-Water Monitoring Wells" (1991) pages 101-102 and Nevada Regulatory Statutes NAC, Chapter 534. 


\section{UE-5f}

Well UE-5f is located $1.62 \mathrm{~km}$ southeast of well UE-11a, and $964 \mathrm{~m}$ southeast of emplacement hole U-5i (Figure 52). As stated above, potentiometric data (Winograd and Thordarson, 1975) indicate the general direction of groundwater flow in the area to be from the northwest towards the southeast; therefore, UE-5f is located downgradient from the test conducted in emplacement hole U-5i.

\section{Well Construction}

Well UE-5f (Figure 53) was drilled in 1965, as an exploratory hole in extreme northern Frenchman Flat to a total depth of $335.3 \mathrm{~m}$ using air-foam with conventional circulation. Land surface elevation at the well site is approximately 1006.1 m MSL. During construction, $50.8-\mathrm{cm}$-diameter casing was set within the borehole to a depth of $25.3 \mathrm{~m}$ and the annular space between this casing and the wellbore cemented to the surface. Below this casing, $25.1-\mathrm{cm}$-diameter hole was drilled to total depth. UE-5f penetrated only alluvium sediments. Following construction of the well, the fluid level was reported at a depth of $272.2 \mathrm{~m}$, approximately $2.4 \mathrm{~m}$ lower in elevation (MSL) than the water level measured in UE-11a.

During FY96, DRI personnel conducted a visit to the well site at UE-5f. The wellhead at UE-5f consists of the $50.8-\mathrm{cm}$-diameter casing cut off at ground level. This casing is capped with a short section of the 50.8-cm-diameter casing with a flat steel plate welded on top. The cap is held in place over the well casing with four pieces of angle iron welded onto the well casing. A total depth/fluid level check performed in the well indicated the presence of a solid bridge within the wellbore at a depth of $169.6 \mathrm{~m}$.

\section{Discussion/Recommendations}

Well UE-5f is located downgradient from the underground nuclear test conducted in emplacement hole U-5i, and well UE-11a (Figure 54). If the underground test conducted at U-5i impacted the water table, wells UE-11a and UE-5f could provide valuable information on radionuclide transport in northern Frenchman Flat. Well UE-11a would provide upgradient baseline water quality data; well UE-5f would provide downgradient monitoring of the impact on groundwater quality produced by the event conducted at $\mathrm{U}-5 \mathrm{i}$.

Until action can be taken regarding the recompletion of well UE-5f, the wellhead should be rehabilitated as soon as possible to prevent contamination of the well by surface water or other materials.

\section{Test Well D}

One underground nuclear test (U-4ak), conducted below $50 \mathrm{~m}$ above the water table, is located within one kilometer of Test Well D (Figure 55). Potentiometric data (Winograd and Thordarson, 1975) indicate the general direction of groundwater flow in this area to be from the west towards the east. Test Well D is located $617.1 \mathrm{~m}$ southwest of the test conducted in 


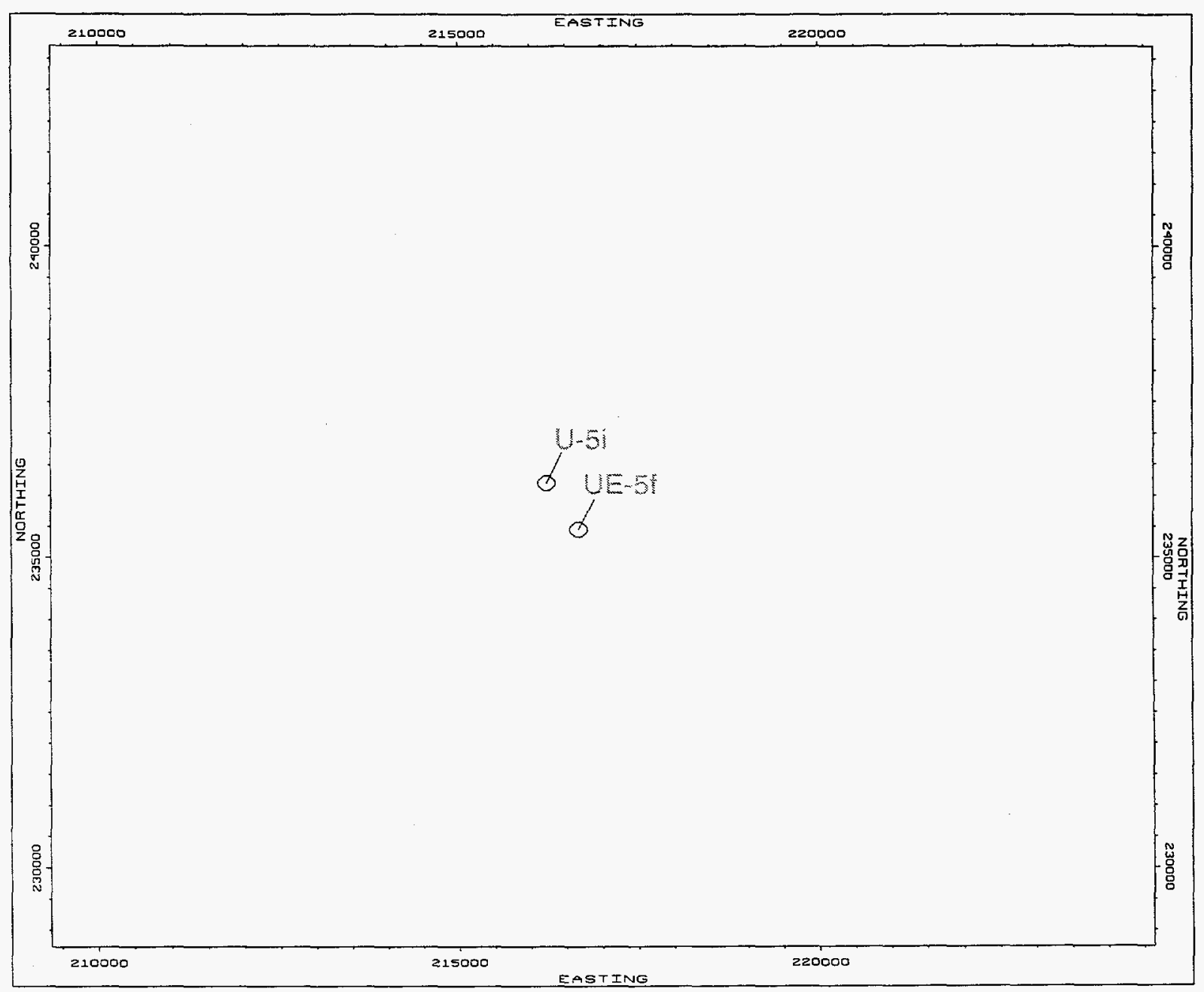

Figure 52. Map showing relative location of UE-5f and U-5i. 


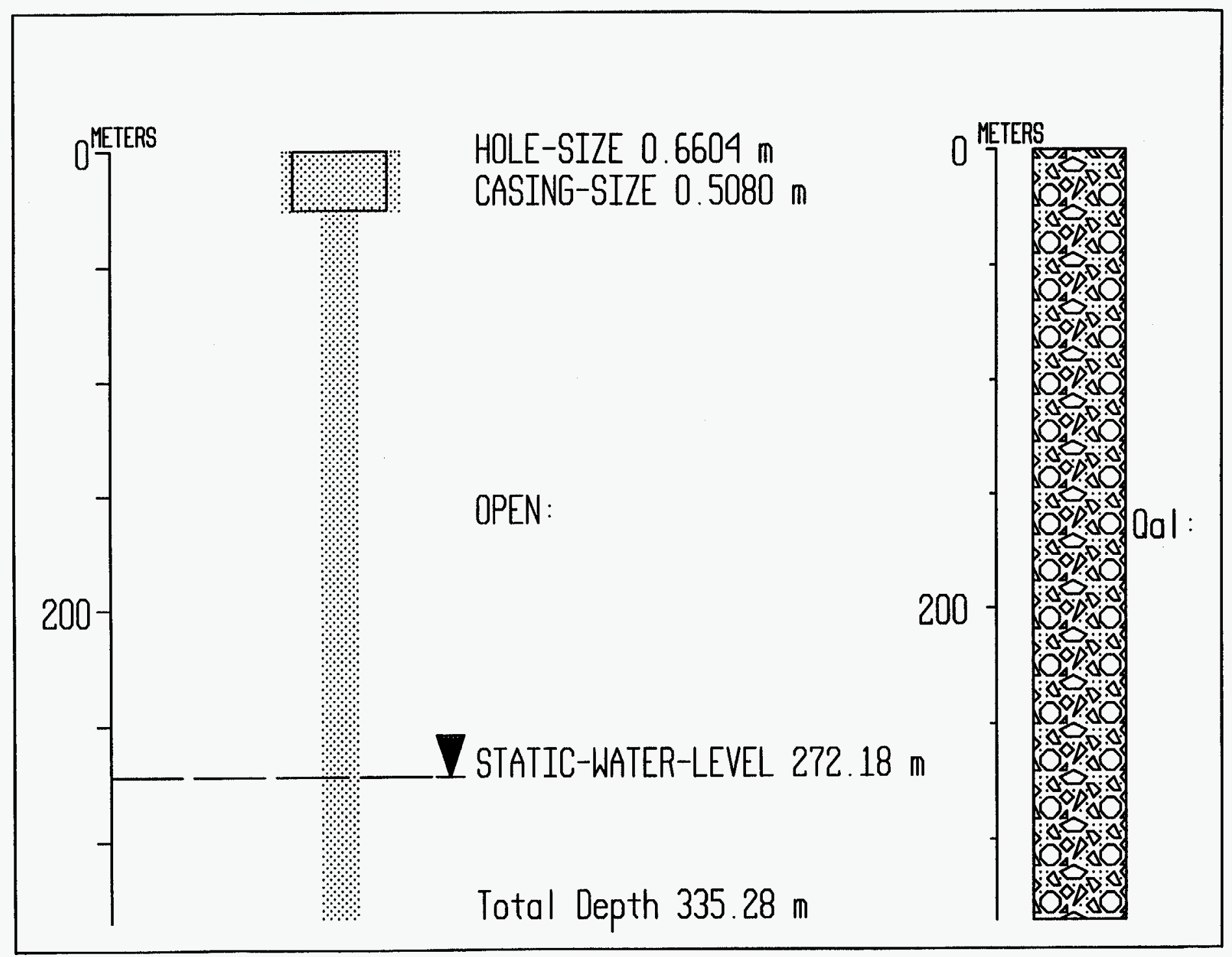

Figure 53. Well construction and lithology at UE-5f. 


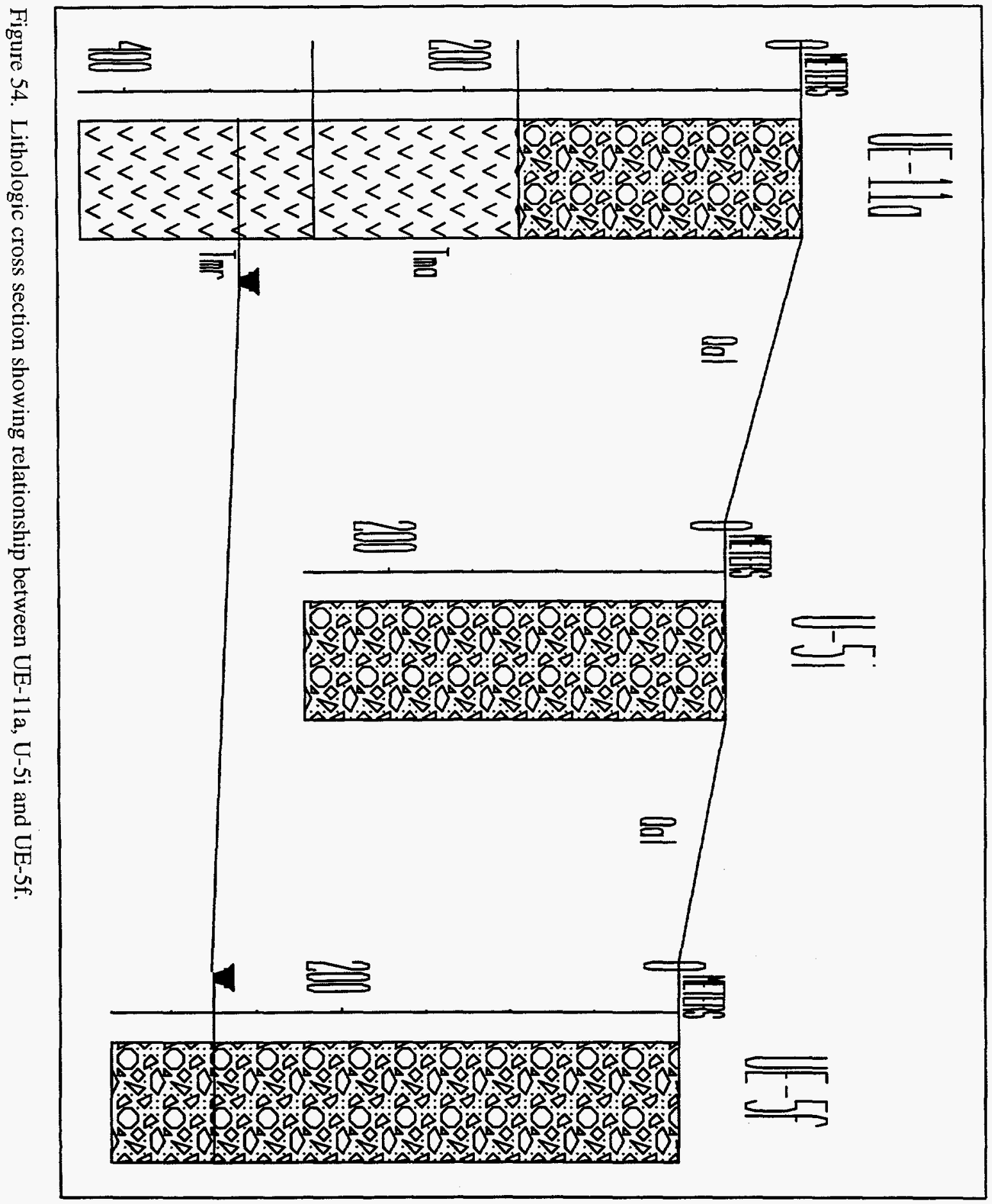


emplacement hole U-4ak. The depth of burial for the event conducted in hole U-4ak is listed as $445 \mathrm{~m}$ below land surface, approximately $49 \mathrm{~m}$ above the estimated water table depth of 493.8 $\mathrm{m}$.

\section{Well Construction}

Test Well D (Figure 56) was drilled as a hydrologic exploration hole in 1961 to a total depth of $594.4 \mathrm{~m}$. Rotary drilling using conventional circulation with drilling mud was utilized to drill to just above the water table at a depth of $531.6 \mathrm{~m}$. Land surface elevation at the well site is 1265.5 $\mathrm{m}$ MSL. The remainder of the hole was drilled using cable tools to avoid contamination of the saturated interval by drilling fluids. The well contains two strings of casing. The first string is $32.4 \mathrm{~cm}$ in diameter and extends from the surface to $518.2 \mathrm{~m}$ below land surface. The annular space between this casing and the wellbore was not cemented to the surface, however, cement was placed at both the bottom and the top of the casing. The second casing string is $27.3 \mathrm{~cm}$ in diameter and extends from 502.9 to $579.1 \mathrm{~m}$ below ground level. This second string contains slots over the interval between 540.1 to $573.6 \mathrm{~m}$. This casing string was not cemented within the wellbore. The contact between Tertiary and Paleozoic intervals was penetrated by the wellbore at a depth of $533.4 \mathrm{~m}$. The Paleozoic interval consists of interbedded carbonates and siltstones to a depth of $560.8 \mathrm{~m}$ which are underlain by an argillite to total depth. Static fluid level within the well is reported at $525.2 \mathrm{~m}$ below land surface.

During FY95, DRI personnel conducted a visit to the well site to determine wellhead conditions and the current conditions within the well. The wellhead at Test Well D consists of approximately $30 \mathrm{~cm}$ of the 32.4-cm-diameter casing extending above ground level. An approximately 1.5 - by $1.5-\mathrm{m}$ concrete pad, approximately $25 \mathrm{~cm}$ thick, has been poured around the casing. The casing is covered with a hinged, locked, flat steel lid. DRI personnel obtained a combination temperature/electrical conductivity/pH $\log$ from within Test Well D. Fluid level within the well was measured at $525.1 \mathrm{~m}$ below land surface. Total depth was measured at 578.9 $\mathrm{m}$. This total depth measurement corresponds with the bottom of the liner placed within the well. The drilling history for Test Well D (Thordarson et al., 1962) indicates the 27.3-cm-diameter casing was landed on argillite, which subsequently became a shoulder when drilling was continued with a smaller bit. It is likely that the DRI logging tools run in the hole hung up on this shoulder and there is additional open hole below the measured total depth. The temperature profile obtained from Test Well D, shown in Figure 57, illustrates the relationship between the thermal conductivity of the lithologies penetrated by the wellbore and the observed thermal gradients. Higher thermal conductivity rocks (dolomite and limestone) produce lower thermal gradients $\left({ }^{\circ} \mathrm{C} / \mathrm{m}\right)$; lower thermal conductivity rocks (siltstones and argillites) produce greater thermal gradients. These changes in the temperature profile agree well with the lithology for the borehole as recorded in the Test Well $\mathrm{D}$ hole history. The temperature, electrical conductivity, and $\mathrm{pH}$ profiles obtained from the well do not indicate the presence of vertical fluid movement within the well. 


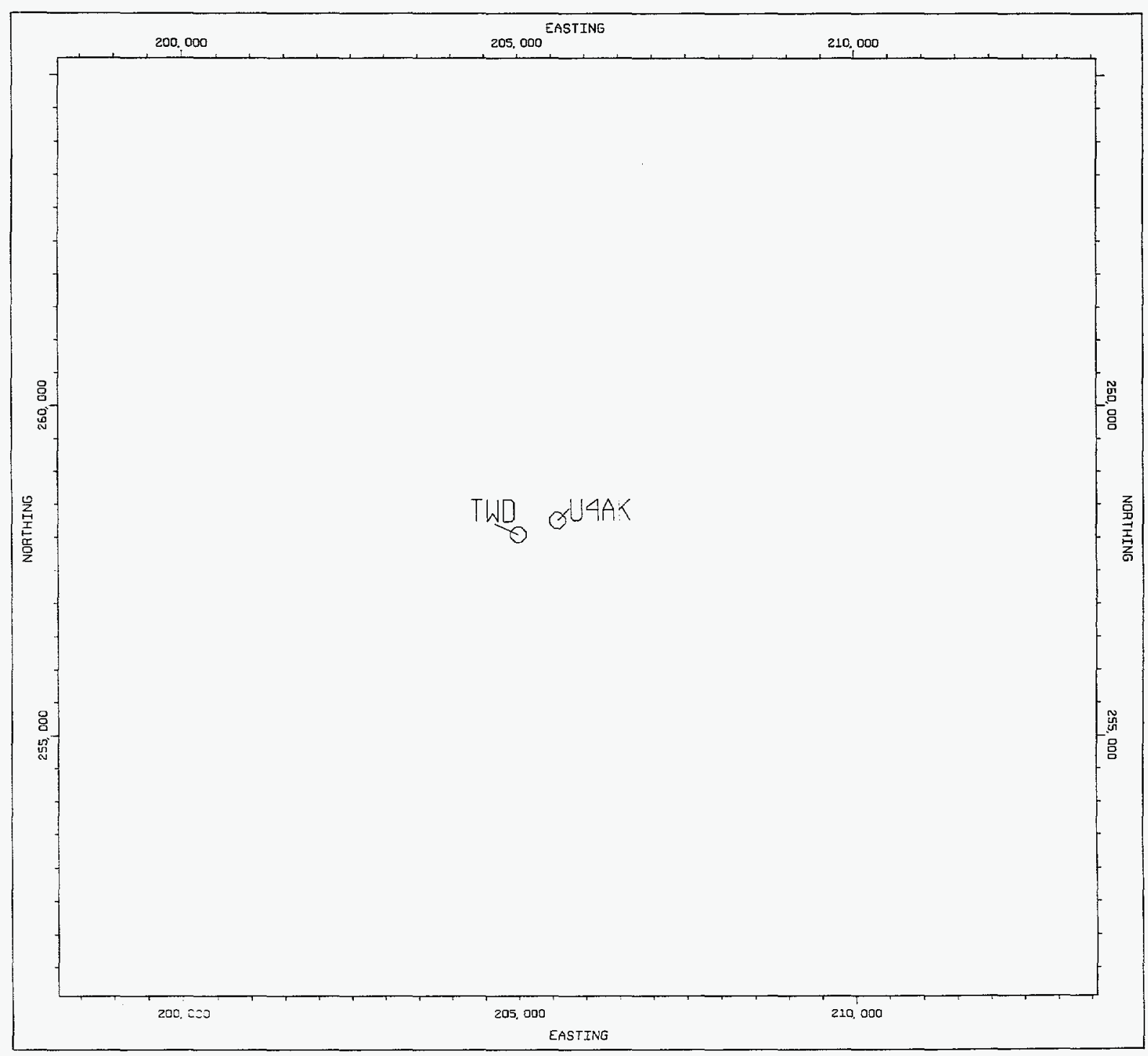

Figure 55. Map showing relative location of Test Well D and U-4ak. 

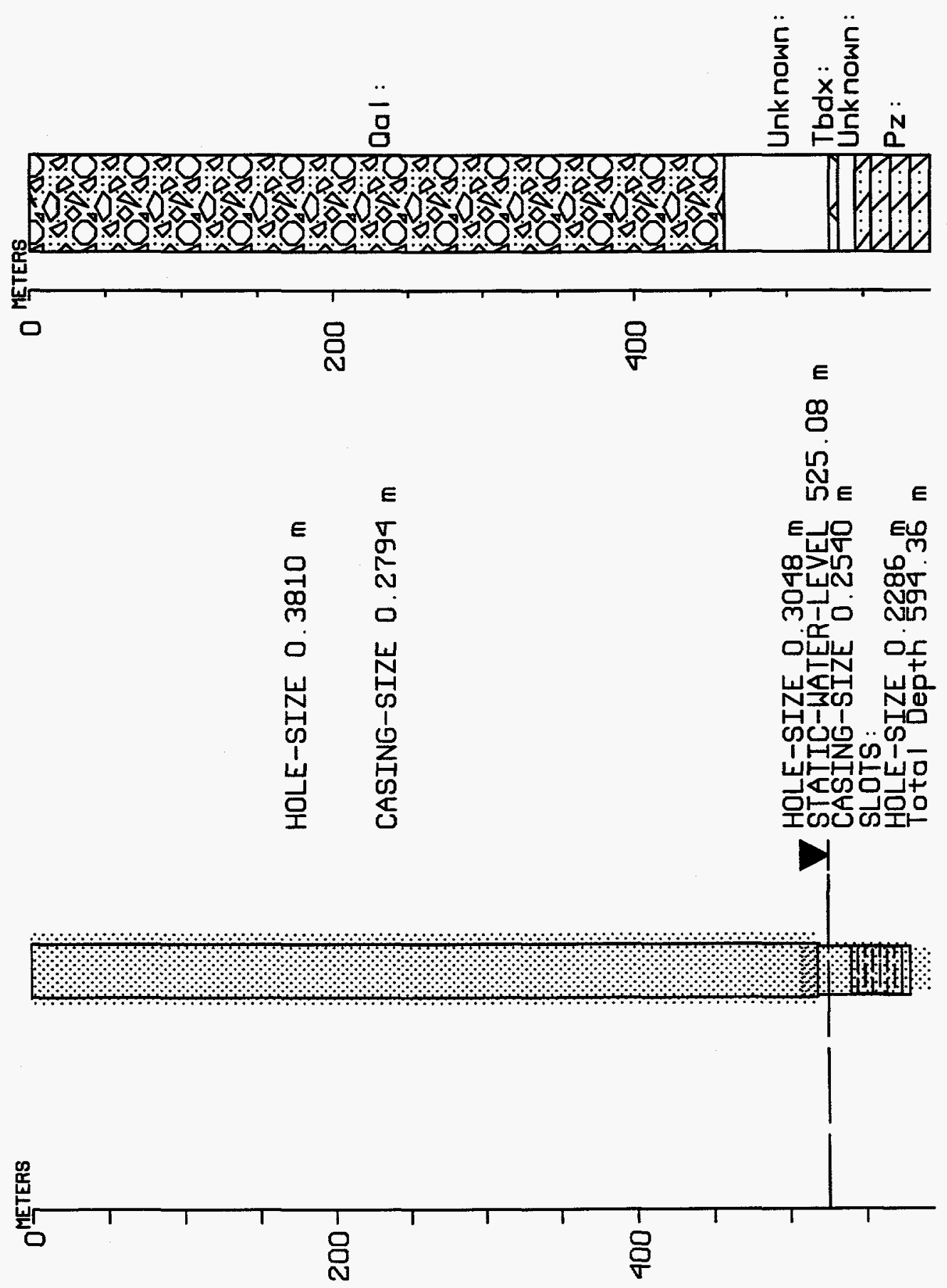

是 


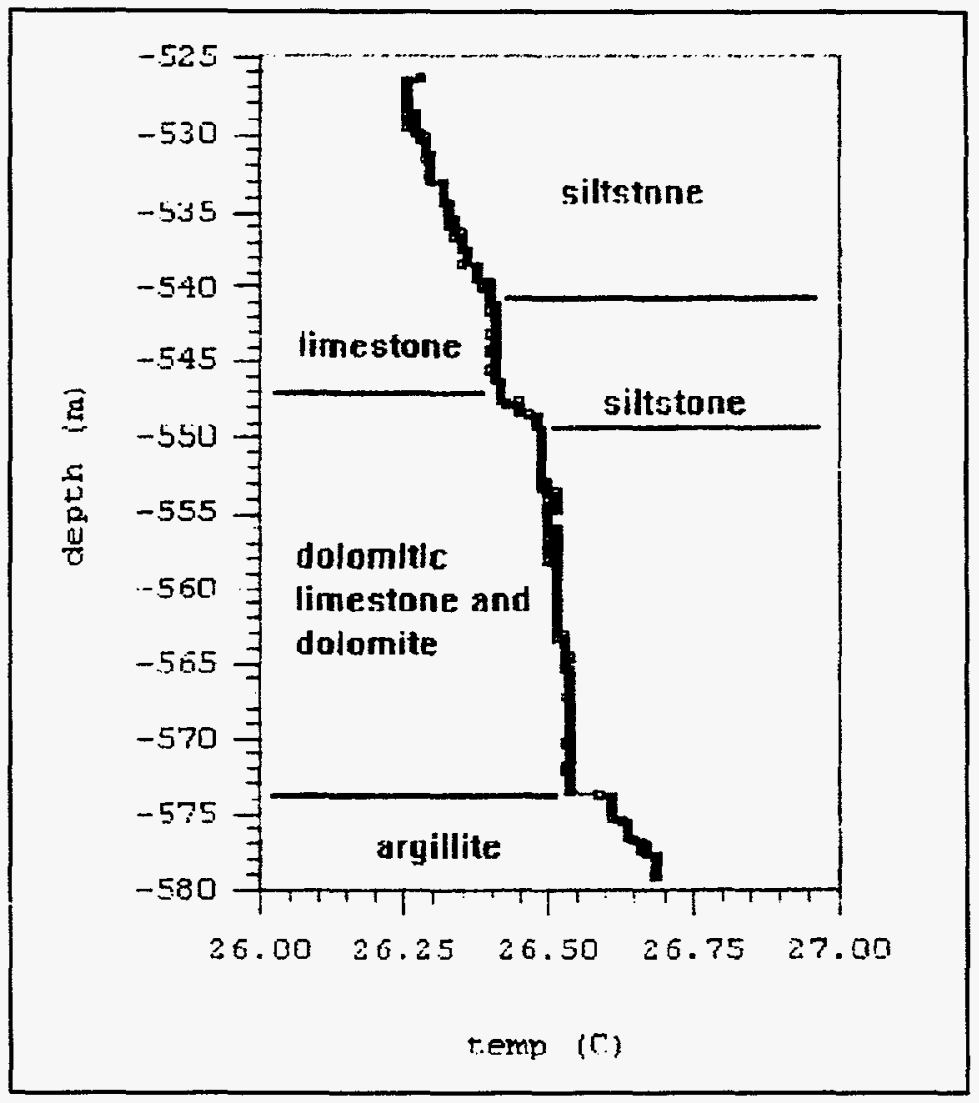

Figure 57. Temperature log from Test Well D.

Test Well D is currently sampled on a regular basis as part of the NTS Long-Term Hydrologic Monitoring Program. Sampling results do not indicate an elevated tritium concentration in fluids from the well.

\section{Discussion/Recommendations}

Although not directly downgradient from the underground test conducted in emplacement hole U-4ak, Test Well D is located in an area where numerous underground tests have been conducted. Additionally, Test Well D is located in an area of the NTS where groundwater quality monitoring locations are otherwise not available.

Due to the current completion of Test Well D (uncemented liner casing), it is not possible to recomplete the well to isolate Tertiary and Paleozoic units within the well and continue to access the Paleozoic interval. Additionally, the existing casings are of insufficient size to permit deepening and recompletion of the well. The Tertiary units overlying the Paleozoic interval are zeolitized, air-fall tuffs of apparently low permeability and should not contribute greatly to the fluid produced from the well. The most likely use for Test Well D is continued monitoring by sampling with a bailer to detect any increase in tritium concentration in fluids from the well. 
Samples more representative of formation fluids could be obtained with the installation of a Moyno pump within the well. The installation of a pump and monitoring line would permit purging of the well prior to sampling, and monitoring of fluid level within the well.

The wellhead at Test Well D should be rehabilitated to conform with EPA guidelines and Nevada state regulations.

\section{UE-2ab}

Well UE-2ab is located $0.821 \mathrm{~km}$ northwest of emplacement hole U-2fc (Figure 58). Potentiometric data (Winograd and Thordarson, 1975) indicate the general direction of groundwater flow in the area to be from the northwest towards the southeast. The depth of burial for the event conducted in emplacement hole U-2fc was $536.1 \mathrm{~m}$ below land surface, approximately $43 \mathrm{~m}$ above the estimated depth to the water table of $579.1 \mathrm{~m}$.

\section{Well Construction}

Well UE-2ab was drilled as a geological exploration hole in 1970 to a total depth of 387.1 $\mathrm{m}$ (Figure 59). Land surface elevation at the drill site is $1345 \mathrm{~m}$ MSL. During construction of the well, 34-cm-diameter casing was placed in the borehole to a depth of $24.4 \mathrm{~m}$. The annular space between this casing and the borehole was cemented to the surface. Below this casing, a 31.1-cm-diameter hole was drilled to total depth. Conventional circulation with air-foam was used in all phases of the construction of the well.

Paleozoic carbonate units were penetrated from $362.7 \mathrm{~m}$ to total depth. The carbonate units are overlain by alluvium; no Tertiary volcanic units were encountered by the borehole. The wellbore did not penetrate the water table.

In July 1994, a site visit was conducted to determine the condition of the wellhead and to determine the current total depth of the borehole. The wellhead at UE-2ab consists of approximately $23 \mathrm{~cm}$ of the 66-cm-diameter surface casing placed in the well extending above ground level. Inside the 66-cm-diameter casing, the $31.1-\mathrm{cm}$-diameter casing extends above ground level to approximately the same height as the 66-cm-diameter casing. A flat steel plate covers the top of the 31.1-cm-diameter casing. The cover is not lockable but is held in place by four machine bolts welded to the edge of the steel plate. Total depth of the well was measured at $328.1 \mathrm{~m}$ below ground level.

\section{Discussion/Recommendations}

Well UE-2ab is located upgradient from the underground test conducted in emplacement hole U-2fc. As evident in the cross section showing lithologic correlations between UE-2ab and U-2fc (Figure 60), the two boreholes are separated by the Carpet Bag Fault system. The Carpet Bag Fault system consists of north-south-trending normal faults that are down-thrown to the east.

Well UE-2ab is a good candidate for recompletion because it could provide valuable hydrologic information concerning the water quality east of the Carpet Bag Fault system in 


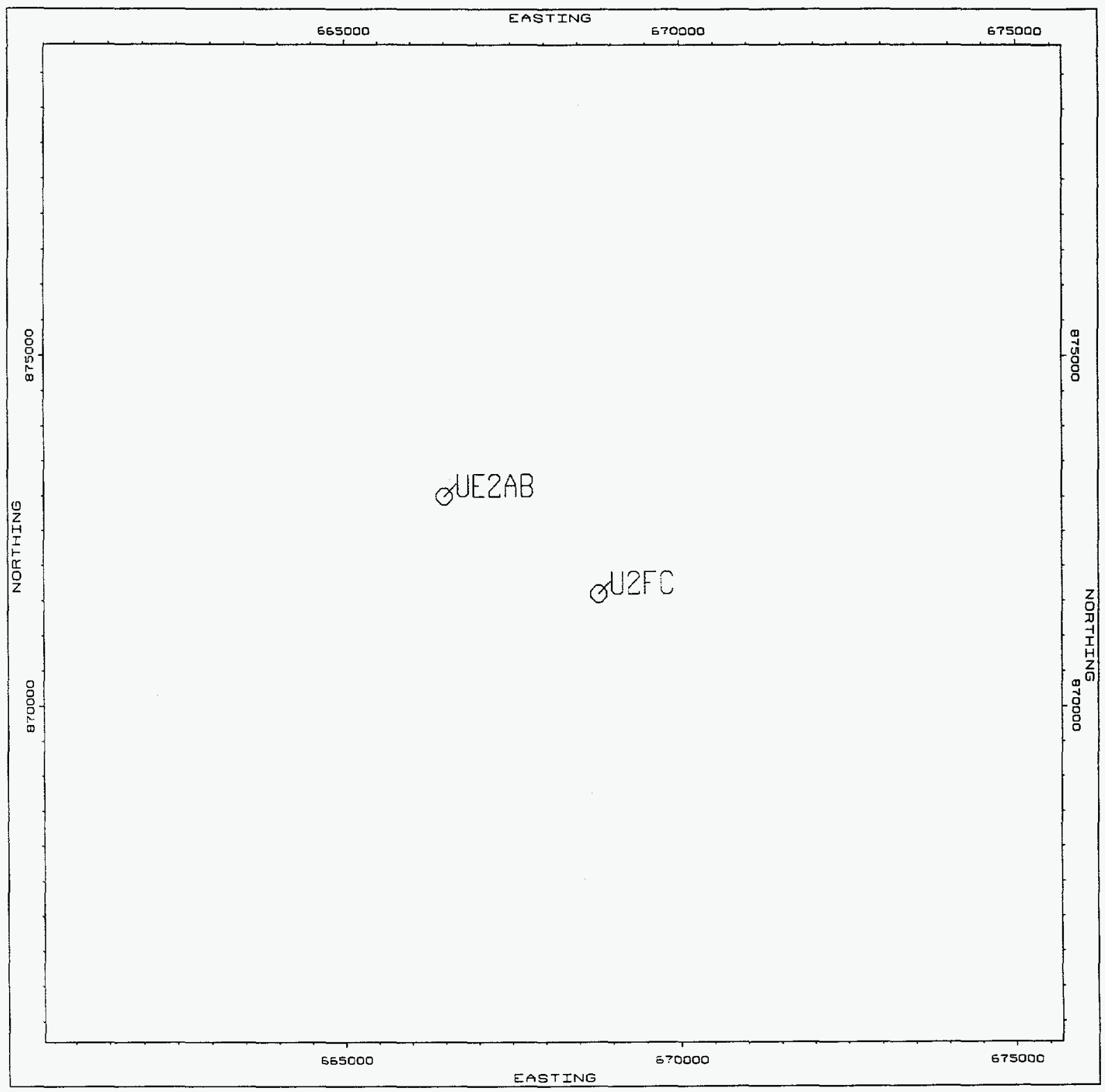

Figure 58. Map showing relative location of UE-2ab and U-2fc. 


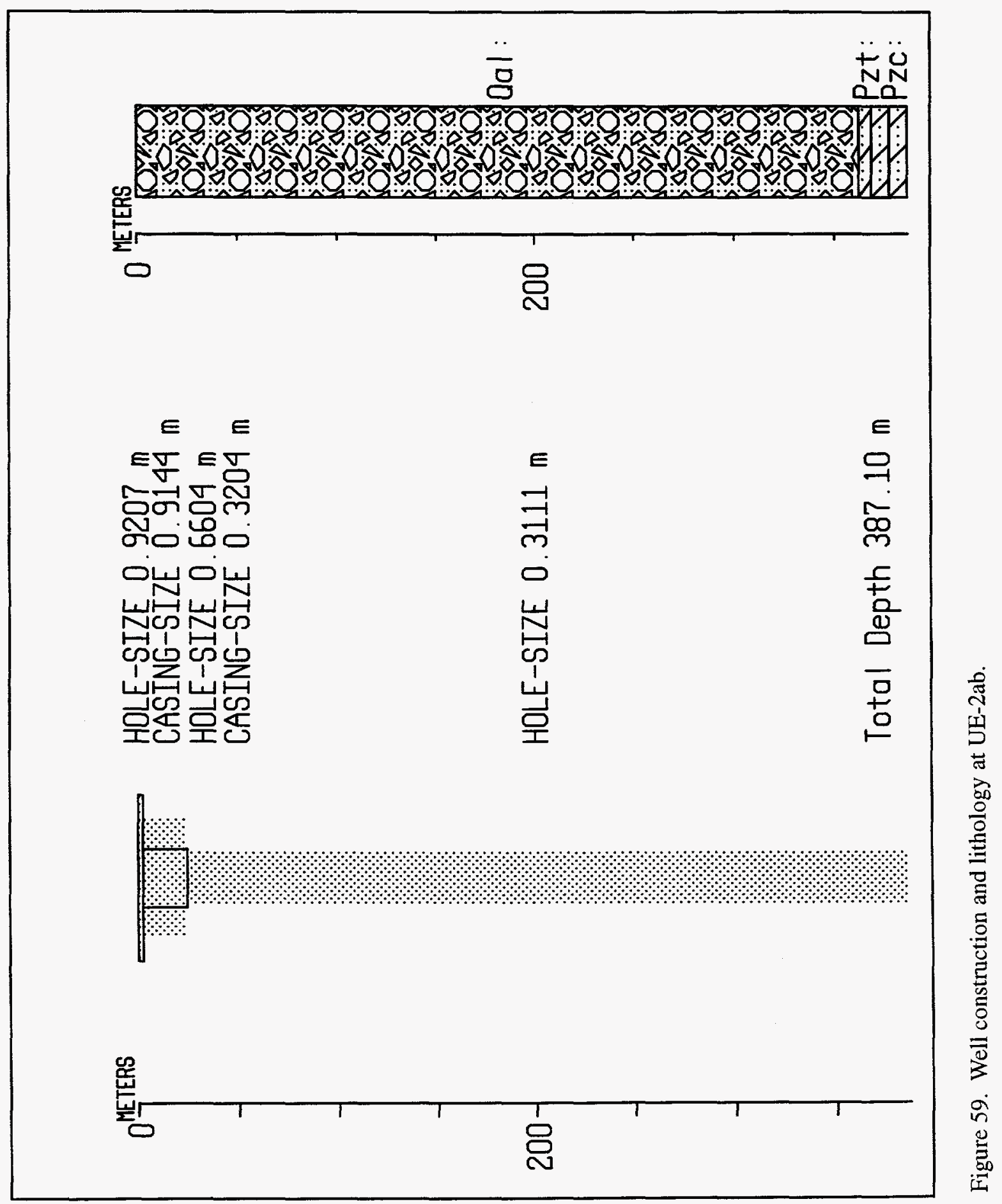




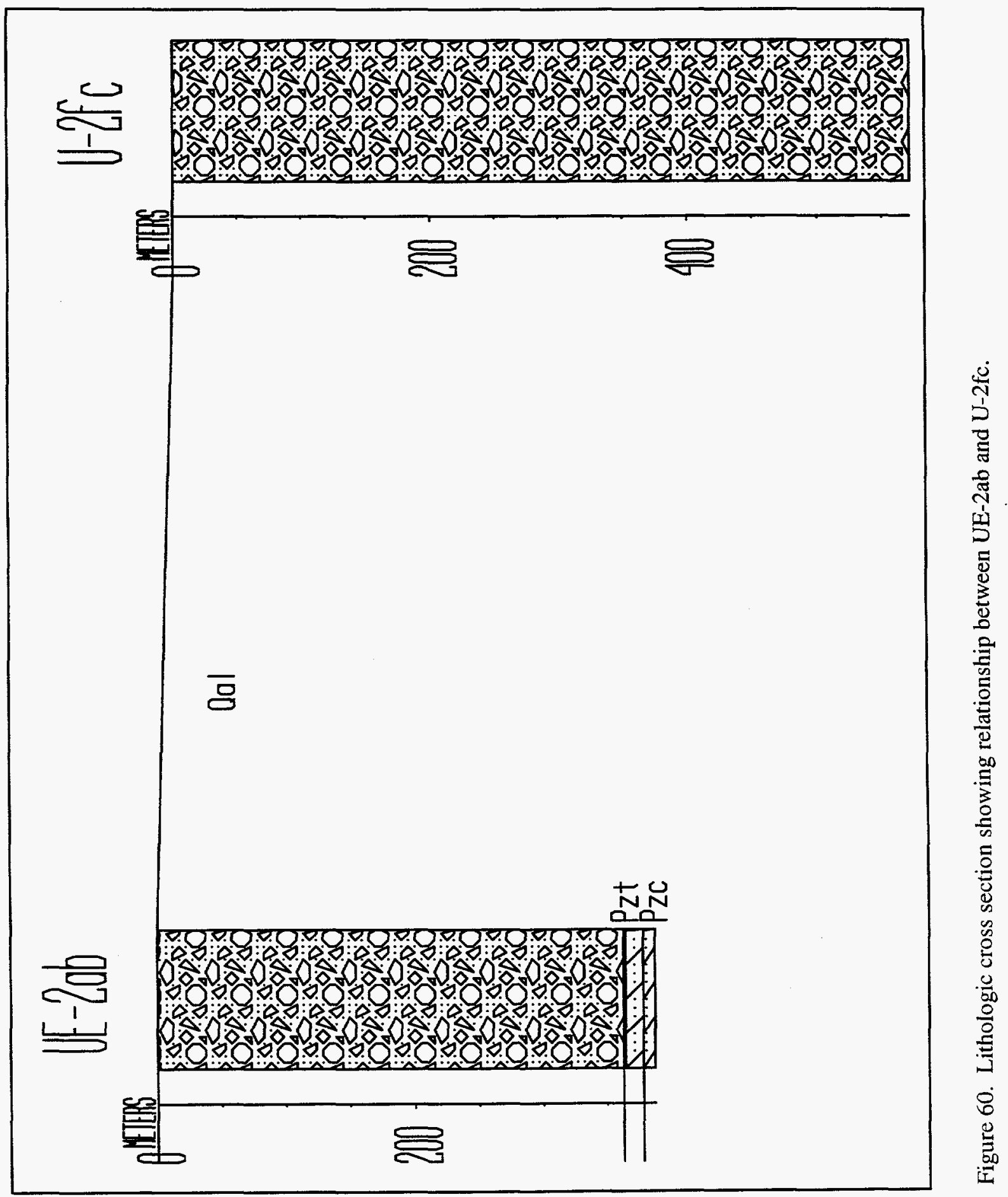


northern Yucca Flat and the role of the Carpet Bag Fault system in the groundwater flow system in northern Yucca Flat. Well UE-2ab is located in a portion of Yucca Flat where groundwater monitoring locations are currently not available. Additionally, the current completion of UE-2ab, with the relatively large-diameter casing cemented within the wellbore, and the depth of the existing borehole, would greatly facilitate the deepening and recompletion of the well as a groundwater quality monitoring location. Based on estimated depth to water table for emplacement holes U-2fc, U-2fe, U-2bv, and U-2ev, well UE-2ab would require deepening by approximately $190 \mathrm{~m}$ to penetrate the water table.

To recomplete UE-2ab as a groundwater monitoring location, the well could be cleaned of bridges and fill and deepened into the saturated portion of the Paleozoic interval. If hole instability is encountered (caving or collapse of the wellbore), casing could be installed to stabilize the wellbore above the saturated Paleozoic interval. The borehole would be deepened until interval(s) of hydrologic interest are encountered, as determined by hydrologic testing and geophysical logs. The well would then be completed with gravel pack and slotted casing over the interval(s) of interest. The installation of a Moyno pump and monitoring line within the recompleted well would facilitate sampling and water level measurements.

Until action can be taken to recomplete the well, the wellhead at UE-2ab should be rehabilitated to prevent contamination of the well.

\section{UE-3d}

Two underground nuclear tests (U-3dd and U-3fd) were conducted below $50 \mathrm{~m}$ above the water table within one kilometer of well UE-3d. U-3dd and U-3fd are located approximately 0.44 and $0.73 \mathrm{~km}$, respectively, southeast of well UE-3d (Figure 61). Potentiometric data (Winograd and Thordarson, 1975) indicate the general direction of groundwater flow in the area to be from the north towards the south. The depth of burial for the events conducted in emplacement holes U-3dd and U-3fd was $451.1 \mathrm{~m}$ and $454.1 \mathrm{~m}$ below land surface, approximately $30.5 \mathrm{~m}$ and $27.4 \mathrm{~m}$ above the estimated depth to the water table in this area of Yucca Flat of $481.6 \mathrm{~m}$.

\section{Well Construction}

Construction of well UE-3d began in 1981, with the drilling of a 91.4-cm-diameter hole to a total depth of $36.6 \mathrm{~m}$ (Figure 62). Surface casing, $50.8 \mathrm{~cm}$ in diameter, was placed in the 91.4-cm-diameter hole to a depth of $36.3 \mathrm{~m}$ and the annular space between this surface casing and the borehole filled with cement to the surface. At this point, construction of the hole was suspended. Drilling records do not indicate that the cement placed at the bottom of the casing was ever drilled out.

In FY96, DRI personnel conducted a site visit to UE-3d to determine current wellhead conditions. The wellhead at UE-3d consists of approximately $40 \mathrm{~cm}$ of the $50.8-\mathrm{cm}$-diameter surface casing extending above ground level. The surface casing is covered with a flat steel plate approximately $90 \mathrm{~cm}$ in diameter . 


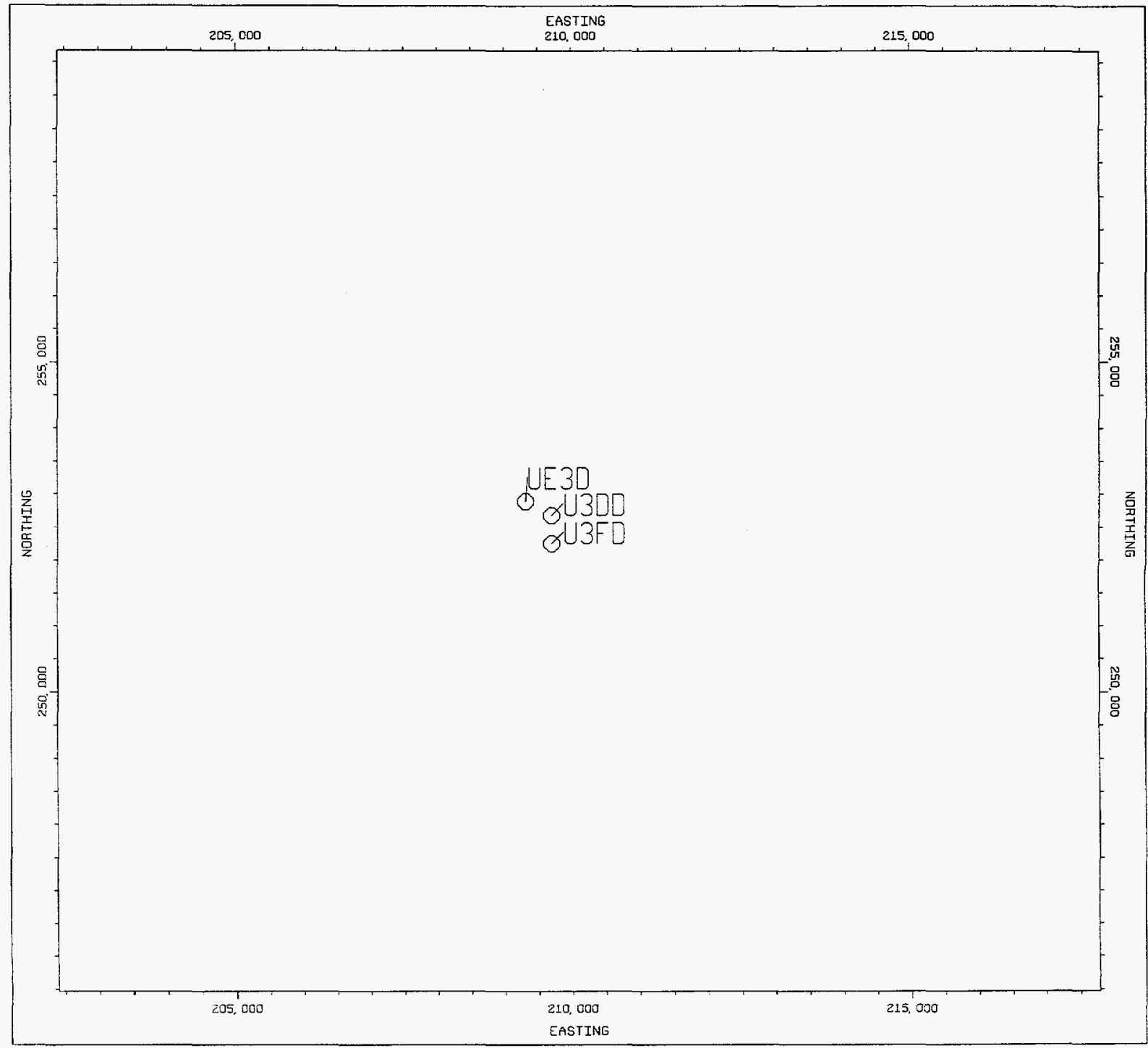

Figure 61. Map showing relative location of UE-3d, U-3dd and U-3fd. 


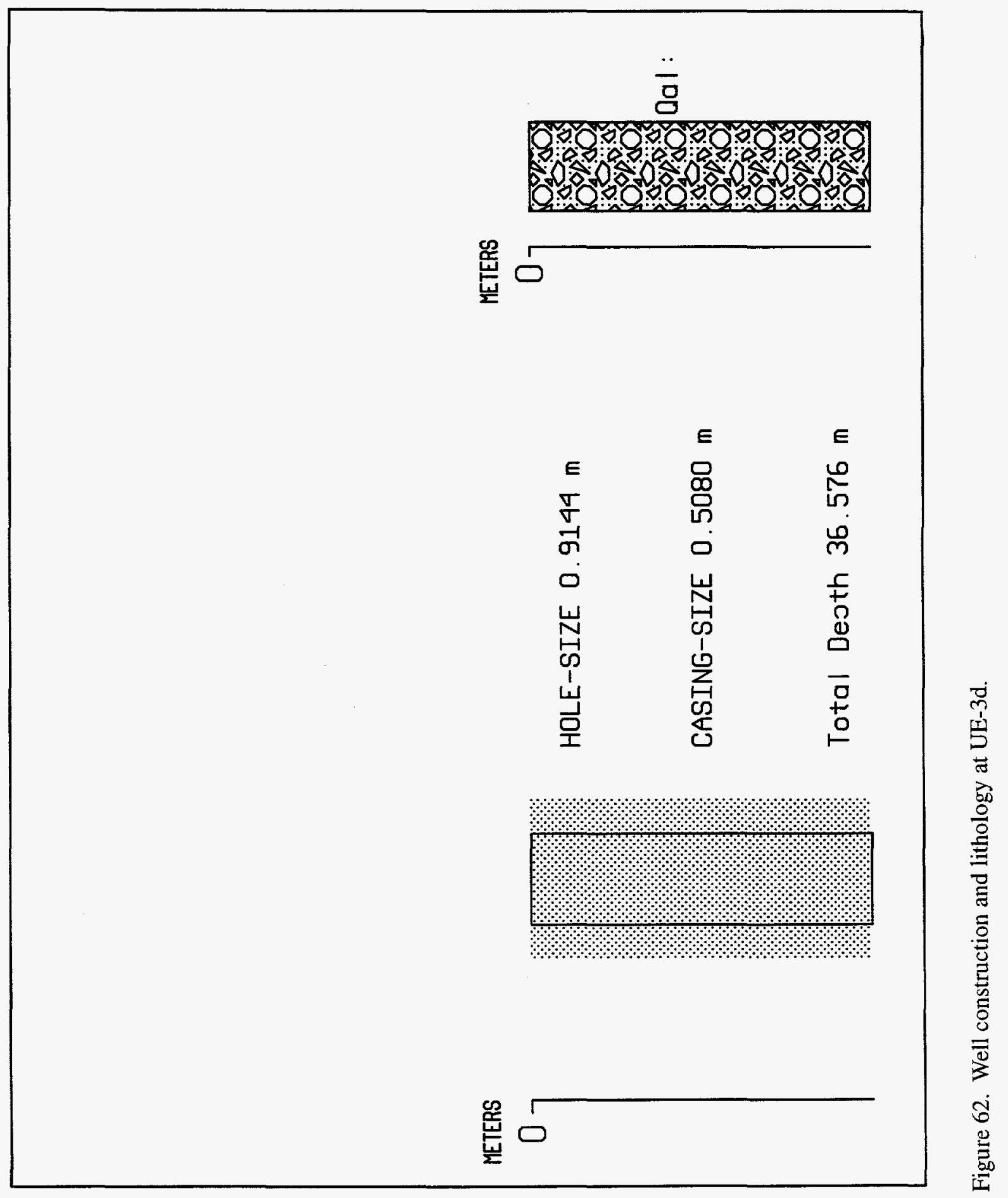




\section{Discussion/Recommendations}

Although well UE-3d is located upgradient from the tests conducted at $\mathrm{U}-3 \mathrm{dd}$ and $\mathrm{U}-3 \mathrm{fd}$, UE-3d could be an ideal candidate for recompletion as an NTS groundwater quality monitoring location. The well is located in central Yucca Flat where numerous underground tests have been conducted. It is located approximately $15 \mathrm{~m}$ from the northwest corner of the intersection of 3-12 and 3-08 roads, and hydrologically downgradient from the low-level radioactive waste disposal facility in Area 3.

This recompletion could consist of construction of a borehole below the surface casing to within the Paleozoic carbonate units. This borehole could then be completed as a monitoring location within the Paleozoic carbonate aquifer. However, due to the location of UE-3d, downgradient from the Area 3 low-level radioactive waste facility, it may be preferable to recomplete the well as a water quality monitoring location within the Tertiary volcanic aquifer. The Tertiary volcanic aquifer consists of more densely welded portions of the Rainier Mesa Tuff unit that underlie this portion of Yucca Flat below the water table.

Until action can be taken to recomplete the well, the wellhead at UE-3d should be rehabilitated to prevent contamination of the well.

\section{Jangle Test Hole \#A2}

Two underground nuclear tests, U-2eo and U-2ei were conducted between 25 and $50 \mathrm{~m}$ above the water table within one kilometer of Jangle Test Hole \#A2. U-2eo and U-2ei are located approximately 0.55 and $0.67 \mathrm{~km}$, southeast and southwest, respectively, of Jangle Test Hole \#A2 (Figure 63). Potentiometric data (Winograd and Thordarson, 1975) indicate the general direction of groundwater flow in the area to be from the north towards the south. The depth of burial for the events conducted in emplacement holes U-2eo and U-2ei were $536.4 \mathrm{~m}$ and 530.3 $\mathrm{m}$ below land surface, approximately $45.7 \mathrm{~m}$ and $49.7 \mathrm{~m}$ above the estimated depth to the water table in this area of Yucca Flat of approximately $581 \mathrm{~m}$.

\section{Well Construction}

Jangle Test Hole \#A2 was drilled in 1952 in northern Yucca Flat. Little information is available concerning this borehole. Total depth is reported as approximately $54 \mathrm{~m}$, however, no information could be found relating to borehole diameter or completion.

Although the general location of the well is recorded (Nevada State Coordinates), an extensive search in the field could not positively locate the well. A round steel fitting approximately $50 \mathrm{~cm}$ in diameter set above a circular conduit composed of masonry bricks was found. This conduit was filled almost to ground level with dirt. Due to the dirt fill, it could not be determined how deep the brick conduit extended below ground level. 


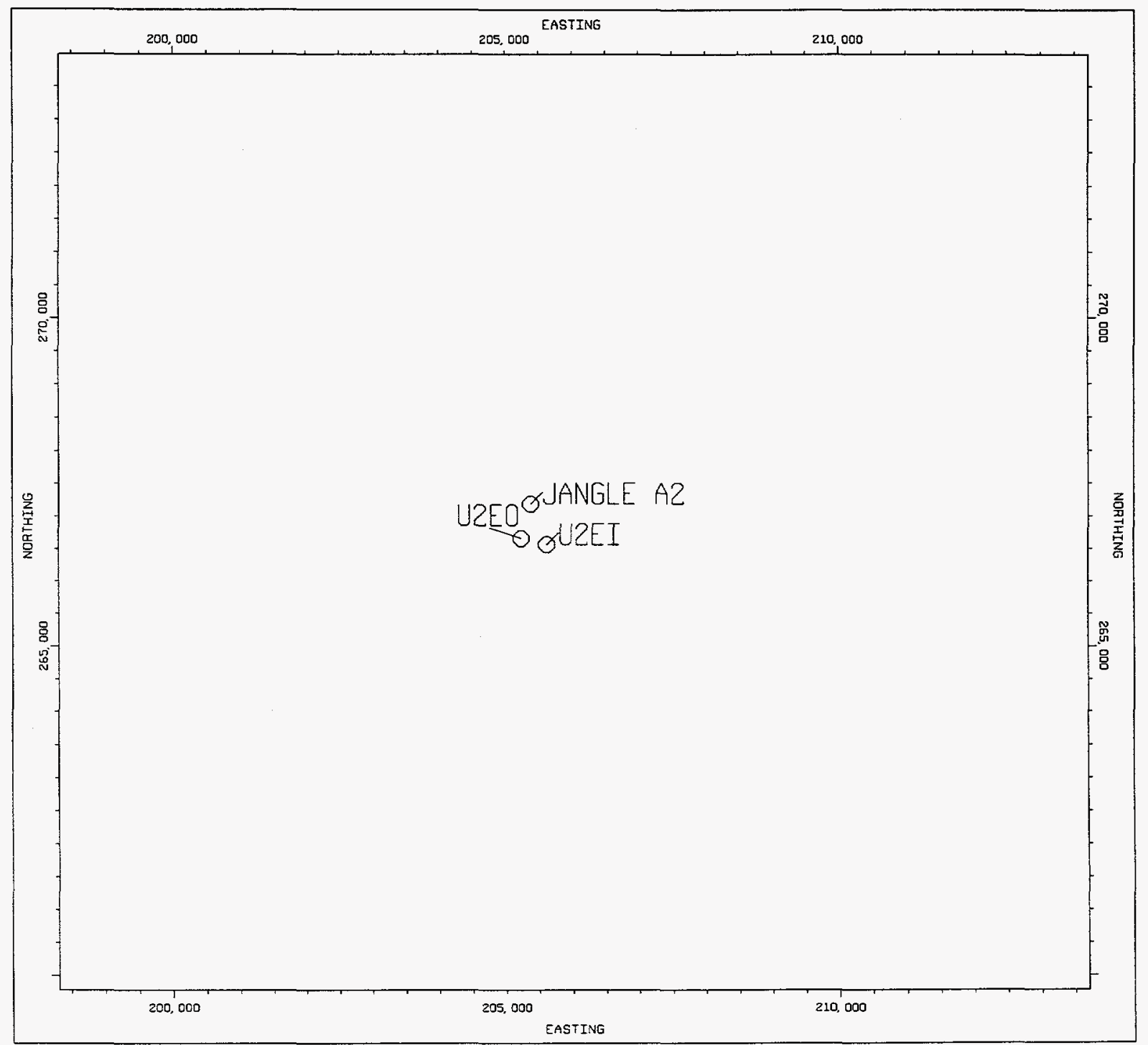

Figure 63. Map showing relative location of Jangle A2, U-2eo and U-2ei. 


\section{Discussion/Recommendations}

It is unlikely that this well could be located, but even if located, it would probably not be suitable for recompletion as a groundwater quality monitoring location. This well should be listed as destroyed or lost and removed from the NTS open borehole inventory.

\section{SUMMARY}

A total of 40 existing wells at the NTS were determined to be located within $1000 \mathrm{~m}$ of underground nuclear tests conducted near (within $50 \mathrm{~m}$ ), or below, the water table (Table 2). Four are located on Pahute Mesa, eight within, or near, the granitic Climax Stock in extreme northern Yucca Flat, five in Frenchman Flat, and the remaining 23 in Yucca Flat. Many of these wells may be suitable for recompletion as monitoring wells, but would require varying degrees of effort to produce viable groundwater monitoring locations. These efforts range from the simple removal of tubing and placement of a Moyno pump and monitoring lines, to the virtual construction of completely new wells. The remainder of the 40 wells either should be plugged and abandoned, are constructed as to make recompletion as a groundwater monitoring location difficult, if not impossible, or require only wellhead rehabilitation.

Of the four wells on Pahute Mesa, PM-1 and UE-20n \#1 would require only the placement, or replacement of a Moyno pump and monitoring line within the existing wells. PM-1 is one of the deepest existing wells at the NTS and would provide valuable information on water quality deep beneath Pahute Mesa. UE-20n \#1 is located immediately downgradient from a collapse chimney and could provide valuable information on contaminate transport if sampled on a regular basis. Another well, UE-20e\#1, would require the removal of bridges and fill from the borehole and recompletion of the well with gravel pack and casing, as well as a Moyno pump and monitoring line. UE-20e\#1 would provide a groundwater monitoring location within the upper saturated interval. Well UE-20e is not suitable for recompletion as a groundwater monitoring location and should be plugged and abandoned.

Two of the six wells in Frenchman Flat, UE-11a, which is upgradient, and UE-5f, which is downgradient from the test conducted at U-5I, are located in extreme northern Frenchman Flat where groundwater quality monitoring locations are currently not available. Recompletion of either, or both, of these wells would require the removal of bridges and fill from the borehole and recompletion of the well with gravel pack and casing, as well as a Moyno pump and monitoring line.

Well UE-5n, located in central Frenchman Flat, is of interest due to its location near the Cambric ditch, through which tritiated water was discharged from RNM \#2S to Frenchman Dry Lake for 17 years. It is not known whether increased tritium levels detected in bailed samples from UE-5n are due to the migration of contaminated water through the vadose zone to the water table from Cambric ditch or are the result of contamination of the well during sampling. Installation of a Moyno pump string and monitoring line would permit purging of the well prior 
to sampling to determine the source of the elevated tritium in water from the well. If it is shown that the contamination is the result of migration of fluid from Cambric ditch, continued periodic sampling could provide valuable information on contaminate transport rates through the vadose zone at the NTS.

The remaining three wells located in Frenchman Flat, RNM \#1, RNM \#2, and RNM \#2S, do not require recompletion. However, continued sampling of fluid from these wells may provide valuable information on radionuclide transport at the NTS.

Of the eight wells located in and around the Climax Stock in extreme northern Yucca Flat, four, UE-15h, Marble \#1, Marble \#2, and Marble \#3, could not be located in the field. Another two of the eight wells, UE-15g and UE-15g, were determined to be plugged with cement to the surface. One of the other two wells located within the granitic Climax Stock, U-15k Test Hole, is of small diameter and is not suitable for recompletion by deepening or the installation of gravel-packed slotted tubing, however, the well is open to total depth and is of sufficient diameter to accept a Moyno pump string and monitoring line. It is unknown whether the water level measured within U-15k Test Hole reflects the actual water table, perched water, water left from the construction of the well, or is the result of surface runoff into the well. Placement of the Moyno pump string and monitoring line would permit purging and sampling, as well as hydrologic testing, of the well. The other well located within the granitic Climax Stock, UE-15b Exploration Hole \#1, would require the removal of bridges and fill from the wellbore. The existing casing at UE-15b Exploration Hole \#1 would permit the placement of gravel packed casing over intervals of hydrologic interest as determined by geophysical logs and hydrologic testing.

Of the 23 wells located within Yucca Flat, five, UE-10L \#1, U-9ca \#1, U-9 ITS UE-U-22, U-9 ITS UE-U-29 \#1, and U-9 ITS UE-U-29 \#2, are located within approximately 2,000 m of one another in north-central Yucca Flat. There are currently no groundwater quality monitoring locations in this portion of Yucca Flat. Three of the wells, U-9 ITS UE-U-22, U-9 ITS UE-U-29 \#1, and U-9 ITS UE-U-29 \#2, would require substantial deepening to penetrate the water table within the Paleozoic interval. UE-10L \#1 and U-9ca \#1 originally penetrated into the Paleozoic interval below the water table and both or either apparently could be recompleted as groundwater monitoring locations within the Paleozoic carbonate aquifer. However, UE-10L \#1 would require the cleaning of bridges and fill from within the borehole, and although U-9ca \#1 appears to be open, the well contains a lost wireline and pressure transducer with collapse of the wellbore a possible reason the transducer and wireline were lost in the hole.

UE-2ab is located in eastern north-central Yucca Flat, east of the Carpet Bag Fault system. It would require substantial deepening to penetrate saturated units of the Paleozoic carbonate aquifer. However, UE-2ab is located in a portion of Yucca Flat where groundwater quality monitoring locations are currently not available and near the Carpet Bag Fault system, which may play a substantial role in the hydrologic flow system in Yucca Flat. 
UE-7ns is located in east-central Yucca Flat and has been sampled by bailer as part of the NTS groundwater monitoring network, with sampling results indicating a tritium concentration of approximately $300 \mathrm{pCi} / \mathrm{L}$. Recompletion of UE- $7 \mathrm{~ns}$ through the installation of a Moyno pump and monitoring line would permit purging of the well prior to sampling. Continued sampling of the well on a regular basis could provide valuable information on contaminate transport within the carbonate aquifer.

Well UE-7k is located in central Yucca Flat. Recompletion of this well as a groundwater quality monitoring location within the Paleozoic carbonate aquifer would require cleaning the wellbore of bridges and fill, and the installation of gravel-packed casing with a Moyno pump and monitoring line.

Wells UE-4ai and UE-4al are located within approximately $1250 \mathrm{~m}$ of one another in west-central Yucca Flat, west of the Yucca Fault system. Recompletion of UE-4ai as a groundwater quality monitoring location within the Paleozoic carbonate aquifer would require substantial deepening of the existing well. UE-4al is reported to have been stemmed with sand from total depth to ground level. It may be possible to drill out this sand and produce a viable groundwater quality monitoring location within the carbonate aquifer. Recompletion of UE-4al would include the placement of gravel-packed casing with a Moyno pump and monitoring line to facilitate purging of the well prior to sampling and to obtain water-level measurements.

Well UE-3d is located in south-central Yucca Flat downgradient from the Area 3 low-level radioactive waste facility. The well consists of surface casing set to a depth of approximately 37 $\mathrm{m}$. Following placement of the surface casing, construction of the well was suspended. Recompletion of this well would require construction of new borehole from below the surface casing to below the water table. The well could be recompleted as a Paleozoic carbonate aquifer monitoring location or, if saturated portions of the Tertiary aquifer were encountered, as a water quality monitoring location within the Tertiary volcanic aquifer. Recompletion of UE-3d would include the placement of casing within the well with gravel-packed slotted intervals over units of hydrologic interest as determined by geophysical logs and hydrologic testing. Recompletion would include the installation of a Moyno pump and monitoring line to facilitate purging of the well prior to sampling and to obtain water-level measurements.

Due to their current completions, Test Well D and Test Well \#7 are not suitable for recompletion. Test Well $\mathrm{D}$ provides access to the Paleozoic carbonate aquifer. Test Well \#7 penetrates saturated units of the volcanic confining unit. The most likely use for Test Well D and Test Well $\# 7$ is continued monitoring by sampling with a bailer to detect any increase in tritium concentration in fluids from the wells.

Jangle Test Holes \#A2 and \#A4 in Yucca Flat could not be positively located in the field. Test Holes \#1, \#5, and \#6 appear to have been stemmed with sand and the casing exposed at the surface welded shut. Well UE-3e \#4 provides groundwater monitoring locations within the volcanic confining unit in Yucca Flat and does not require recompletion. Well UE-4t also 
provides groundwater monitoring locations within the volcanic confining unit in Yucca Flat and does not require recompletion.

Well U-3cn \#5 in Yucca Flat provides a monitoring location within the Paleozoic carbonate aquifer in close proximity to the test conducted in U-3cn. The status of the submersible pump in place within the well is unknown. If sampled on a regular basis, $U-3 \mathrm{cn} \# 5$ could provide valuable information on radionuclide transport near underground nuclear tests.

Well UE-2a in Yucca Flat contains lost drilling string. Recompletion is not possible and the well should be plugged and abandoned. 


\section{REFERENCES}

Aller L., T. Bennett, G. Hackett, R. Petty, J. Lehr, H. Sedoris, D. Nielson and J. Denne, 1991. Handbook of Suggested Practices for the Design and Installation of Ground-Water Monitoring Wells, EPA/600/4-89/034, p. 101-102.

Black, S.C., W.M. Glines and Y.E. Townsend, 1995, NV Annual Site Environmental Report, U.S. Department of Energy, DOE/NV/11432-175.

Blankennagel, R.K. and J.E. Weir, Jr., 1973. Geohydrology of the eastern part of Pahute Mesa, Nevada Test Site, Nye County, Nevada. U.S. Geological Survey Professional Paper 712-B, $35 \mathrm{p}$.

Buddemeier, R.W. and Isherwood, D., 1985. Radionuclide Migration Project 1984 Progress Report: Lawrence Livermore National Laboratory report UCRL-53628.

Chapman J.B. and B. Lyles, 1993. Groundwater chemistry at the Nevada Test Site: Data and preliminary interpretations, Desert Research Institute Publication No. 45100.

Erickson, S., 1991. Report of drilling and radionuclide migration investigations at UE-20n \#1, Pahute Mesa, Nevada Test Site, 1987, Desert Research Institute Publication No. 45081.

Gillespie, D.R. and P.R. Seaber, 1993. Recompletion of existing wells for a deep groundwater characterization and monitoring network at the Nevada Test Site, in Proceedings: ER '93 Environmental Remediation Conference, Augusta, Georgia, October 24-28, 1993, pp. 261-265.

Gillespie, D.R., J.D. Donithan and P.R. Seaber, 1996. Nevada Test Site water-supply wells, Desert Research Institute Publication No. 45138.

Hawkins W.L., D.A. Trudeau and T.M. Miheve, 1989. Hydrologic testing in exploratoration drill hole UE-4t, Yucca Flat, the Nevada Test Site, in Proceedings: Fifth Symposium on Containment of Underground Nuclear Explosions: U.S. Dept. of Energy Report Conf-870961 - Vol. 2, p. 387-398.

Hoffman, D.C., R. Stone and W.W. Dudley, Jr., 1977. Radioactivity in the underground environment of the Cambric nuclear explosion at the Nevada Test Site, Los Alamos National Laboratory, LA-6877-MS Informal Report, pp. 89.

Schoff, S.L. and J.E. Moore, 1964. Chemistry and movement of ground water, Nevada Test Site. U.S. Geological Survey Trace Elements Investigations Report TEI-838, 75 p.

Thompson, J., 1991. Interim report of the drilling history and analysis for Nevada Tests Site hole UE-3e \#4, Los Alamos National Laboratory Report LA-12042-MS.

U.S. Department of Energy, 1993. NV Annual Site Environmental Report. 
U.S. Department of Energy, 1994. NV Annual Site Environmental Report.

Waddell, R.K., J.H. Robison and R.K. Blankennagel, 1984. Hydrology of Yucca Mountain and vicinity, Nevada-California--Investigative results through mid-1983: U.S. Geological Survey Water-Resources Investigations Report 84-4267, 35 p.

White, A.F., 1979. Geochemistry of groundwater associated with tuffaceous rocks, Oasis Valley, Nevada: U.S. Geological Survey Professional Paper 712-E, 25 p.

Winograd, I.J. and W. Thordarson, 1975. Hydrogeologic and hydrochemical framework, south-central Great Basin, Nevada-California, with special reference to the Nevada Test Site: U.S. Geological Survey Professional Paper 712-C, C1-C126. 
APPENDIX A

TESTS CONDUCTED BELOW $25 \mathrm{M}$ ABOVE SWL

\begin{tabular}{|c|c|c|c|}
\hline Hole & SWL(m) & $\operatorname{DOB}(\mathbf{m})$ & WP Medium \\
\hline $\mathrm{U}-10 \mathrm{k}$ & 568 & 679 & $\mathrm{n} / \mathrm{a}$ \\
\hline U-10af & 564 & 521 & $\mathrm{n} / \mathrm{a}$ \\
\hline U-11f & 302 & 265 & $\mathrm{n} / \mathrm{a}$ \\
\hline $\mathrm{U}-11 \mathrm{~g}$ & 302 & 264 & $\mathrm{n} / \mathrm{a}$ \\
\hline$U-12 q$ & 575 & 545 & $\mathrm{n} / \mathrm{a}$ \\
\hline $\mathrm{U}-15 \mathrm{a}$ & 457 & 463 & Granite \\
\hline U-19ab & 613 & 661 & Tuff \\
\hline U-19ad & 646 & 625 & Lava \\
\hline U-19ar & 646 & 628 & Lava \\
\hline U-19as & 668 & 978 & Tuff \\
\hline U-19au & 625 & 622 & Lava \\
\hline U-19ay & 649 & 640 & Tuff \\
\hline $\mathrm{U}-19 \mathrm{~b}$ & 646 & 820 & Rhyolite \\
\hline $\mathrm{U}-19 \mathrm{bg}$ & 641 & 622 & Lava \\
\hline $\mathrm{U}-19 \mathrm{c}$ & 707 & 683 & Tuff \\
\hline$U-19 d$ & 668 & 671 & Rhyolite \\
\hline $\mathrm{U}-19 \mathrm{e}$ & 676 & 1452 & $\mathrm{n} / \mathrm{a}$ \\
\hline $\mathrm{U}-19 \mathrm{f}$ & 704 & 817 & Rhyolite \\
\hline U-19g & 628 & 856 & Rhyolite \\
\hline $\mathrm{U}-19 \mathrm{i}$ & 668 & 728 & Tuff \\
\hline U-19l & 640 & 668 & Tuff \\
\hline U-19p & 689 & 881 & Tuff \\
\hline U-19q & 668 & 1311 & $\mathrm{n} / \mathrm{a}$ \\
\hline $\mathrm{U}-19 \mathrm{u}$ & 668 & 911 & Rhyolite \\
\hline $\mathrm{U}-19 \mathrm{v}$ & 686 & 1064 & Rhyolite \\
\hline U-19ys & 645 & 681 & $\mathrm{n} / \mathrm{a}$ \\
\hline U-19aj & 668 & 637 & $\mathrm{n} / \mathrm{a}$ \\
\hline U-19ak & 667 & 640 & Rhyolite \\
\hline U-19an & 641 & 616 & $\mathrm{n} / \mathrm{a}$ \\
\hline $\mathrm{U}-19 \mathrm{x}$ & 716 & 671 & Rhyolite \\
\hline U-19zs & 668 & 633 & $\mathrm{n} / \mathrm{a}$ \\
\hline $\mathrm{U}-20 \mathrm{a}$ & 658 & 698 & Tuff \\
\hline U-20aa & 571 & 1273 & $\mathrm{n} / \mathrm{a}$ \\
\hline U-20ab & 649 & 689 & $n / a$ \\
\hline $\mathrm{U}-20 \mathrm{ac}$ & 630 & 633 & $\mathrm{n} / \mathrm{a}$ \\
\hline U-20ad & 579 & 681 & $\mathrm{n} / \mathrm{a}$ \\
\hline
\end{tabular}


APPENDIX A

TESTS CONDUCTED BELOW 25 M ABOVE SWL

\begin{tabular}{|c|c|c|c|}
\hline Hole & SWL(m) & $\operatorname{DOB}(\mathrm{m})$ & WP Medium \\
\hline U-20ae & 607 & 680 & $\mathrm{n} / \mathrm{a}$ \\
\hline U-20af & 602 & 645 & $\mathrm{n} / \mathrm{a}$ \\
\hline U-20ag & 614 & 638 & $\mathrm{n} / \mathrm{a}$ \\
\hline U-20ai & 625 & 609 & $\mathrm{n} / \mathrm{a}$ \\
\hline U-20ak & 622 & 608 & $\mathrm{n} / \mathrm{a}$ \\
\hline U-20am & 652 & 640 & $\mathrm{n} / \mathrm{a}$ \\
\hline U-20an & 606 & 597 & $\mathrm{n} / \mathrm{a}$ \\
\hline U-20ap & 652 & 635 & $\mathrm{n} / \mathrm{a}$ \\
\hline U-20ar & 561 & 542 & $\mathrm{n} / \mathrm{a}$ \\
\hline U-20as & 613 & 605 & $\mathrm{n} / \mathrm{a}$ \\
\hline U-20av & 633 & 625 & $\mathrm{n} / \mathrm{a}$ \\
\hline U-20ay & 626 & 620 & $\mathrm{n} / \mathrm{a}$ \\
\hline $\mathrm{U}-20 \mathrm{~b}$ & 640 & 624 & $\mathrm{n} / \mathrm{a}$ \\
\hline $\mathrm{U}-20 \mathrm{bb}$ & 620 & 600 & $\mathrm{n} / \mathrm{a}$ \\
\hline U-20bc & 569 & 564 & $\mathrm{n} / \mathrm{a}$ \\
\hline U-20bd & 621 & 674 & $\mathrm{n} / \mathrm{a}$ \\
\hline U-20be & 675 & 658 & $\mathrm{n} / \mathrm{a}$ \\
\hline $\mathrm{U}-20 \mathrm{bf}$ & 651 & 642 & $\mathrm{n} / \mathrm{a}$ \\
\hline $\mathrm{U}-20 \mathrm{c}$ & 641 & 1402 & $\mathrm{n} / \mathrm{a}$ \\
\hline $\mathrm{U}-20 \mathrm{~d}$ & 632 & 631 & $\mathrm{n} / \mathrm{a}$ \\
\hline $\mathrm{U}-20 \mathrm{e}$ & 556 & 1161 & $\mathrm{n} / \mathrm{a}$ \\
\hline U-20f & 595 & 1219 & $\mathrm{n} / \mathrm{a}$ \\
\hline $\mathrm{U}-20 \mathrm{~g}$ & 615 & 1216 & $\mathrm{n} / \mathrm{a}$ \\
\hline U-20h & 642 & 671 & $\mathrm{n} / \mathrm{a}$ \\
\hline $\mathrm{U}-20 \mathrm{i}$ & 580 & 1166 & $\mathrm{n} / \mathrm{a}$ \\
\hline $\mathrm{U}-20 \mathrm{~m}$ & 387 & 1209 & $\mathrm{n} / \mathrm{a}$ \\
\hline$U-20 n$ & 625 & 1167 & $\mathrm{n} / \mathrm{a}$ \\
\hline $\mathrm{U}-20 \mathrm{p}$ & 280 & 731 & $\mathrm{n} / \mathrm{a}$ \\
\hline $\mathrm{U}-20 \mathrm{t}$ & 632 & 607 & $\mathrm{n} / \mathrm{a}$ \\
\hline$U-20 v$ & 601 & 599 & $\mathrm{n} / \mathrm{a}$ \\
\hline $\mathrm{U}-20 \mathrm{y}$ & 630 & 765 & $\mathrm{n} / \mathrm{a}$ \\
\hline $\mathrm{U}-20 \mathrm{z}$ & 628 & 1265 & $\mathrm{n} / \mathrm{a}$ \\
\hline U-20ah & 610 & 570 & $\mathrm{n} / \mathrm{a}$ \\
\hline $\mathrm{U}-20 \mathrm{aj}$ & 571 & 542 & $\mathrm{n} / \mathrm{a}$ \\
\hline U-20al & 590 & 546 & $\mathrm{n} / \mathrm{a}$ \\
\hline
\end{tabular}


APPENDIX A

TESTS CONDUCTED BELOW $25 \mathrm{M}$ ABOVE SWL

\begin{tabular}{lccc}
\hline Hole & SWL(m) & DOB(m) & WP Medium \\
\hline U-20ao & 596 & 549 & $\mathrm{n} / \mathrm{a}$ \\
U-20aq & 574 & 549 & $\mathrm{n} / \mathrm{a}$ \\
U-2am & 567 & 745 & $\mathrm{n} / \mathrm{a}$ \\
U-2at & 549 & 645 & $\mathrm{n} / \mathrm{a}$ \\
U-2av & 578 & 625 & $\mathrm{n} / \mathrm{a}$ \\
U-2aw & 553 & 573 & $\mathrm{n} / \mathrm{a}$ \\
U-2ax & 585 & 655 & $\mathrm{n} / \mathrm{a}$ \\
U-2az \#1 & 552 & 529 & $\mathrm{n} / \mathrm{a}$ \\
U-2bs & 526 & 564 & $\mathrm{n} / \mathrm{a}$ \\
U-2bu & 491 & 529 & $\mathrm{n} / \mathrm{a}$ \\
U-2dg & 576 & 662 & $\mathrm{n} / \mathrm{a}$ \\
U-2dj & 577 & 688 & $\mathrm{n} /$ \\
U-2dr & 567 & 600 & $\mathrm{n} / \mathrm{a}$ \\
U-2dz & 548 & 536 & $\mathrm{n} / \mathrm{a}$ \\
U-2ek & 536 & 716 & $\mathrm{n} / \mathrm{a}$ \\
U-2el & 541 & 690 & $\mathrm{n} / \mathrm{a}$ \\
U-2en & 540 & 658 & $\mathrm{n} / \mathrm{a}$ \\
U-2fa & 554 & 668 & $\mathrm{n} / \mathrm{a}$ \\
U-2fb & 539 & 542 & $\mathrm{n} / \mathrm{a}$ \\
U-2ge & 567 & 543 & $\mathrm{n} / \mathrm{a}$ \\
U-2gh & 479 & 469 & $\mathrm{n} / \mathrm{a}$ \\
U-2t & 549 & 671 & $\mathrm{n} / \mathrm{a}$ \\
U-2v & 564 & 733 & $\mathrm{n} / \mathrm{a}$ \\
U-2x & 552 & 715 & $\mathrm{n} / \mathrm{a}$ \\
U-2ei & 580 & 530 & $\mathrm{n} / \mathrm{a}$ \\
U-2eo & 582 & 536 & $\mathrm{n} / \mathrm{a}$ \\
U-2ex & 563 & 515 & $\mathrm{n} / \mathrm{a}$ \\
U-2fc & 579 & 536 & $\mathrm{n} / \mathrm{a}$ \\
U-3dd & 482 & 451 & Alluvium \\
U-3ej & 503 & 454 & Alluvium \\
U-3fd & 482 & 454 & Tuff \\
U-3hj & 478 & 451 & Alluvium \\
U-3mt & 503 & 457 & Tuff \\
U-3an & 509 & 753 & Tuff \\
U-3bs & 503 & 485 & \\
\hline & & & \\
\hline
\end{tabular}


APPENDIX A

TESTS CONDUCTED BELOW $25 \mathrm{M}$ ABOVE SWL

\begin{tabular}{lccc}
\hline Hole & SWL(m) & DOB(m) & WP Medium \\
\hline \hline U-3cn & 503 & 713 & Tuff \\
U-3dh & 521 & 503 & Tuff \\
U-3gg & 497 & 640 & Tuff \\
U-3jg & 472 & 454 & Alluvium \\
U-3jn & 503 & 528 & Tuff \\
U-3jq & 527 & 536 & Tuff \\
U-3kz & 500 & 503 & Tuff \\
U-3la & 500 & 564 & Tuff \\
U-3me & 488 & 579 & Tuff \\
U-3mf & 494 & 640 & Tuff \\
U-4a & 506 & 783 & Tuff \\
U-4an & 495 & 475 & n/a \\
U-4ar & 505 & 483 & n/a \\
U-4au & 500 & 489 & n/a \\
U-4c & 533 & 668 & Tuff \\
U-4d & 503 & 640 & Tuff \\
U-4e & 515 & 713 & Tuff \\
U-4f & 506 & 640 & Tuff \\
U-4g & 506 & 640 & Tuff \\
U-4h & 512 & 701 & Tuff \\
U-4i & 521 & 610 & Tuff \\
U-4j & 506 & 640 & Tuff \\
U-4l & 512 & 579 & TuffU-4n \\
506 & 640 & Tuff & \\
U-4o & 500 & 533 & Tuff \\
U-4p & 494 & 518 & Tuff \\
U-4q & 500 & 600 & Tuff \\
U-4t & 506 & 594 & Tuff \\
U-4ak & 494 & 445 & n/a \\
U-4av & 500 & 457 & n/a \\
U-4u & 509 & 640 & Tuff \\
U-5a & 213 & 175 & n/a \\
U-5i & 305 & 256 & Alluvium \\
U-5b & 213 & 193 & n/a \\
U-5e & 213 & 295 & n/a \\
\hline & & & \\
\hline
\end{tabular}


APPENDIX A

TESTS CONDUCTED BELOW 25 M ABOVE SWL

\begin{tabular}{|c|c|c|c|}
\hline Hole & SWL(m) & $\operatorname{DOB}(\mathrm{m})$ & WP Medium \\
\hline $\mathrm{U}-5 \mathrm{k}$ & 213 & 265 & $\mathrm{n} / \mathrm{a}$ \\
\hline $\mathrm{U}-7 \mathrm{ac}$ & 503 & 637 & Tuff \\
\hline U-7ad & 552 & 570 & Tuff \\
\hline U-7ae & 543 & 518 & Tuff \\
\hline U-7af & 546 & 567 & Tuff \\
\hline $\mathrm{U}-7 \mathrm{ag}$ & 521 & 570 & Tuff \\
\hline U-7Ah & 515 & 637 & Tuff \\
\hline U-7ai & 500 & 640 & Tuff \\
\hline U-7ajs & 521 & 640 & Tuff \\
\hline U-7ak & 523 & 655 & $\mathrm{n} / \mathrm{a}$ \\
\hline U-7am & 533 & 594 & Tuff \\
\hline U-7an & 503 & 637 & Tuff \\
\hline U-7ap & 503 & 564 & Tuff \\
\hline U-7aq & 503 & 701 & Tuff \\
\hline $\mathrm{U}-7 \mathrm{au}$ & 503 & 640 & Tuff \\
\hline U-7av & 500 & 564 & Tuff \\
\hline $\mathrm{U}-7 \mathrm{ba}$ & 512 & 564 & Tuff \\
\hline U-7be & 539 & 579 & Tuff \\
\hline U-7bo & 558 & 567 & Tuff \\
\hline $\mathrm{U}-7 \mathrm{bp}$ & 539 & 640 & Tuff \\
\hline $\mathrm{U}-7 \mathrm{br}$ & 500 & 564 & Tuff \\
\hline $\mathrm{U}-7 \mathrm{bs}$ & 506 & 637 & Tuff \\
\hline U-7bu & 500 & 533 & Tuff \\
\hline U-7ca & 518 & 503 & Tuff \\
\hline $\mathrm{U}-7 \mathrm{e}$ & 533 & 555 & Tuff \\
\hline $\mathrm{U}-7 \mathrm{f}$ & 555 & 533 & Tuff \\
\hline $\mathrm{U}-7 \mathrm{i}$ & 567 & 561 & Tuff \\
\hline $\mathrm{U}-7 \mathrm{j}$ & 561 & 564 & Tuff \\
\hline $\mathrm{U}-7 \mathrm{k}$ & 512 & 561 & Tuff \\
\hline$U-7 n$ & 597 & 561 & Limestone \\
\hline$U-7 p$ & 552 & 558 & Tuff \\
\hline $\mathrm{U}-7 \mathrm{r}$ & 549 & 561 & Tuff \\
\hline $\mathrm{U}-7 \mathrm{~s}$ & 567 & 561 & Tuff \\
\hline $\mathrm{U}-7 \mathrm{t}$ & 579 & 561 & Tuff \\
\hline $\mathrm{U}-7 \mathrm{u}$ & 543 & 671 & Tuff \\
\hline
\end{tabular}


APPENDIX A

TESTS CONDUCTED BELOW $25 \mathrm{M}$ ABOVE SWL

\begin{tabular}{lccc}
\hline Hole & SWL(m) & DOB(m) & WP Medium \\
\hline \hline U-7y & 564 & 555 & Tuff \\
U-7y & 543 & 561 & Tuff \\
U-7z & 521 & 560 & Tuff \\
U-7bl & 555 & 518 & Tuff \\
U-7cb & 546 & 503 & Tuff \\
U-9bx & 558 & 582 & n/a \\
U-9cb & 562 & 539 & n/a \\
\hline
\end{tabular}


APPENDIX B

EXISTING WELLS AT THE NTS

\begin{tabular}{|c|c|c|c|c|c|}
\hline Well Name & north(m) & east(m) & $\operatorname{Elev}(\mathrm{m})$ & $\mathrm{TD}(\mathrm{m})$ & SWL(m) \\
\hline$\overline{\text { PM-2 (Area 20) }}$ & 287908 & $\overline{161134}$ & 1703 & 2677 & 258 \\
\hline UE-19c Water Well & 279501 & 183193 & 2144 & 2587 & 705 \\
\hline PM-1 (USGS HTH \#9) (Area 20) & 280752 & 175524 & 1999 & 2395 & 639 \\
\hline UE-15d (Water Well) & 273012 & 207899 & 1398 & 1829 & 203 \\
\hline Water Well 8 (USGS HTH-8) & 268061 & 185927 & 1736 & 1676 & 329 \\
\hline UE-11 & 255117 & 199339 & 1358 & 1627 & 158 \\
\hline UE-18r & 264596 & 172120 & 1688 & 1525 & 416 \\
\hline HTH \#1 USGS (TW-1) (Area 17) & 267265 & 191813 & 1876 & 1282 & 447 \\
\hline UE-1r & 252939 & 206441 & 1232 & 1275 & 496 \\
\hline UE-6d & 248107 & 206502 & 1203 & 1188 & 462 \\
\hline $\mathrm{UE}-14 \mathrm{~b}$ & 242041 & 198153 & 1327 & 1122 & 508 \\
\hline UE-20e \#1 & 284825 & 170980 & 1919 & 1097 & 554 \\
\hline J-13 Water Well (Area 25) & 228358 & 176677 & 1011 & 1063 & 282 \\
\hline Water Well 2 (USGS HTH \#2) & 268224 & 203825 & 1362 & 1043 & 626 \\
\hline HTH-F (TW-F) (Area 27) & 223068 & 201519 & 1263 & 1036 & 529 \\
\hline UE-1h & 249936 & 205740 & 1218 & 1024 & 475 \\
\hline UE-20n \#1 & 276314 & 174113 & 1969 & 1006 & 623 \\
\hline UE-14a & 242041 & 198882 & 1323 & 1006 & $\mathrm{n} / \mathrm{a}$ \\
\hline U-20 Water Well & 277545 & 173458 & 1971 & 996 & 627 \\
\hline U-9ca \#1 & 265999 & 206989 & 1294 & 978 & 564 \\
\hline U-3cn \#5 (Bilby HTH) & 256414 & 209701 & 1223 & 924 & 494 \\
\hline UE-17e Eleana & 260056 & 197037 & 1504 & 914 & $\mathrm{n} / \mathrm{a}$ \\
\hline $\mathrm{UE}-4 \mathrm{av}$ & 260494 & 205458 & 1273 & 858 & $\mathrm{n} / \mathrm{a}$ \\
\hline UE-20bh \#1 & 276834 & 175244 & 2023 & 856 & 675 \\
\hline UE-5c Water Well & 231688 & 213663 & 980 & 817 & $\mathrm{n} / \mathrm{a}$ \\
\hline $\mathrm{U}-3 \mathrm{cn} \# 2$ & 256542 & 209740 & 1242 & 808 & $\mathrm{n} / \mathrm{a}$ \\
\hline UE-1q & 256489 & 206502 & 1244 & 792 & 504 \\
\hline UE-18t & 263893 & 182390 & 1585 & 792 & 279 \\
\hline UE-7k & 258836 & 208909 & 1258 & 777 & $\mathrm{n} / \mathrm{a}$ \\
\hline $\mathrm{UE}-10 \mathrm{j}$ & 270367 & 204354 & 1394 & 766 & 659 \\
\hline $\mathrm{UE}-1 \mathrm{k}$ & 254050 & 206502 & 1235 & 713 & $\mathrm{n} / \mathrm{a}$ \\
\hline $\mathrm{UE}-19 \mathrm{~h}$ & 287701 & 178370 & 2067 & 697 & 644 \\
\hline Test Well \#7 (Area 3) & 257004 & 208682 & 1239 & 693 & 498 \\
\hline UE-20h (UE-20h Ex. Hole) & 279811 & 173049 & 1999 & 690 & $\mathrm{n} / \mathrm{a}$ \\
\hline $\mathrm{UE}-8 \mathrm{f}$ & 268951 & 203002 & 1390 & 685 & $\mathrm{n} / \mathrm{a}$ \\
\hline U-10L \#1 & 266979 & 207739 & 1300 & 673 & 561 \\
\hline UE-7ns & 260786 & 211439 & 1331 & 672 & 601 \\
\hline UE-4al & 258683 & 204999 & 1266 & 667 & $\mathrm{n} / \mathrm{a}$ \\
\hline UE-3e \#4 & 257521 & 207264 & 1244 & 665 & 334 \\
\hline $\mathrm{UE}-20 \mathrm{e}$ & 284855 & 170979 & 1919 & 660 & $\mathrm{n} / \mathrm{a}$ \\
\hline
\end{tabular}


APPENDIX B

EXISTING WELLS AT THE NTS

\begin{tabular}{|c|c|c|c|c|c|}
\hline Well Name & north(m) & $\overline{e a s t(m)}$ & $\operatorname{Elev}(\mathrm{m})$ & $\mathrm{TD}(\mathrm{m})$ & $\mathrm{SWL}(\mathrm{m})$ \\
\hline$\overline{\mathrm{PM}-3 \text { \#1 (Off-site) }}$ & 276155 & 161848 & 1775 & $\overline{653}$ & $\overline{445}$ \\
\hline UE-16d Eleana (Water Well) & 257518 & 197073 & 1428 & 616 & 229 \\
\hline $\mathrm{UE}-4 \mathrm{t}$ & 260776 & 207370 & 1263 & 607 & 90 \\
\hline Army \#1 Water Well (Area 22) & 204490 & 208718 & 961 & 595 & 244 \\
\hline Hagestad \#1 (Area 12) & 271025 & 192369 & 2281 & 595 & $\mathrm{n} / \mathrm{a}$ \\
\hline Test Well D USGS (Area 4) & 258043 & 205008 & 1266 & 594 & 525 \\
\hline UE-1c & 255117 & 202996 & 1228 & 573 & 396 \\
\hline Water Well A USGS (Area 3) & 253898 & 208483 & 1221 & 570 & 489 \\
\hline TW-3 (HTH \#3) (Area 5) & 228657 & 224618 & 1060 & 567 & 337 \\
\hline U-9 ITS UE-U-22 & 264822 & 208239 & 1287 & 554 & $\mathrm{n} / \mathrm{a}$ \\
\hline Well 3 (Water Well) & 249263 & 206581 & 1210 & 549 & 467 \\
\hline U-15b Ex.\#1 & 275502 & 206668 & $\mathrm{n} / \mathrm{a}$ & 549 & $\mathrm{n} / \mathrm{a}$ \\
\hline UE-1e & 254965 & 202265 & 1294 & 522 & $\mathrm{n} / \mathrm{a}$ \\
\hline Water Well C-1 USGS (Area 6) & 240795 & 210961 & 1195 & 520 & 472 \\
\hline $\mathrm{UE}-3 \mathrm{a}$ & 251764 & 212750 & 1230 & 520 & $\mathrm{n} / \mathrm{a}$ \\
\hline UE-10 ITS \#4 & 269869 & 206410 & 1312 & 520 & $\mathrm{n} / \mathrm{a}$ \\
\hline Water Well C USGS (Area 6) & 240817 & 210940 & 1195 & 518 & 470 \\
\hline UE-5n & 229959 & 215315 & 949 & 514 & 215 \\
\hline $\mathrm{UE}-4 \mathrm{ac}$ & 260893 & 200939 & 1302 & 511 & $\mathrm{n} / \mathrm{a}$ \\
\hline TW-B (Area 6) & 247511 & 210529 & 1198 & 511 & 459 \\
\hline $\mathrm{UE}-2 \mathrm{v}(\mathrm{U}-8 \mathrm{a} \# 12)$ & 268234 & 202780 & 1383 & 508 & $\mathrm{n} / \mathrm{a}$ \\
\hline UE-2ce Water Well & 265511 & 199613 & 1452 & 503 & 441 \\
\hline $\mathrm{UE}-1 \mathrm{j}$ & 251307 & 205206 & 1231 & 497 & $\mathrm{n} / \mathrm{a}$ \\
\hline $\mathrm{UE}-8 \mathrm{~h}$ & 269064 & 202614 & 1400 & 491 & $\mathrm{n} / \mathrm{a}$ \\
\hline U-9 ITS UE-U-29 \#2 & 265634 & 208210 & 1293 & 479 & $\mathrm{n} / \mathrm{a}$ \\
\hline Water Well $4 \mathrm{a}$ & 239069 & 209367 & 1099 & 462 & 255 \\
\hline $\mathrm{UE}-5 \mathrm{~m}$ & 223266 & 207873 & $\mathrm{n} / \mathrm{a}$ & 458 & 201 \\
\hline HTH-4 USGS (TW-4) (Off-site) & 204062 & 230363 & 1060 & 457 & 225 \\
\hline Water Well 4 & 239267 & 209671 & 1098 & 451 & 255 \\
\hline UE-16f Eleana & 253701 & 197767 & 1418 & 451 & 112 \\
\hline $\mathrm{UE}-2 \mathrm{u}(\mathrm{U}-2 \mathrm{ca} \# 1)$ & 265236 & 199110 & 1485 & 449 & $\mathrm{n} / \mathrm{a}$ \\
\hline $\mathrm{UE}-12 \mathrm{t} \# 6$ & 274747 & 194594 & 2105 & 445 & 258 \\
\hline $\mathrm{UE}-1 \mathrm{~g}$ & 255574 & 202051 & 1301 & 440 & $\mathrm{n} / \mathrm{a}$ \\
\hline UE-19n & 287121 & 178186 & 2059 & 432 & $\mathrm{n} / \mathrm{a}$ \\
\hline UE-11a & 236869 & 215883 & 1081 & 427 & 345 \\
\hline $\mathrm{UE}-29 \mathrm{a} \# 2$ & 243152 & 178474 & 1215 & 422 & $\mathrm{n} / \mathrm{a}$ \\
\hline UE-4af & 257952 & 202051 & 1312 & 414 & $\mathrm{n} / \mathrm{a}$ \\
\hline $\mathrm{U}-3 \mathrm{mq} \# 1$ & 250048 & 207719 & 1209 & 413 & $\mathrm{n} / \mathrm{a}$ \\
\hline UE-12g.10 \#6 & 269098 & 192682 & 2303 & 406 & $\mathrm{n} / \mathrm{a}$ \\
\hline $\mathrm{Ue}-11 \mathrm{~b}$ & 237378 & 217109 & 1093 & 397 & $\mathrm{n} / \mathrm{a}$ \\
\hline
\end{tabular}


APPENDIX B

EXISTING WELLS AT THE NTS

\begin{tabular}{|c|c|c|c|c|c|}
\hline Well Name & north $(\mathrm{m})$ & east(m) & $\operatorname{Elev}(\mathrm{m})$ & $\mathrm{TD}(\mathrm{m})$ & $\overline{S W L(m)}$ \\
\hline RNM \#1 & 230374 & 214832 & 956 & 397 & $\bar{n} / \mathrm{a}$ \\
\hline HTH-10 USGS (Off-site) & 204536 & 225270 & $\mathrm{n} / \mathrm{a}$ & 397 & $\mathrm{n} / \mathrm{a}$ \\
\hline UE-2ab & 266090 & 203149 & 1345 & 387 & $\mathrm{n} / \mathrm{a}$ \\
\hline $\mathrm{UE}-1 \mathrm{~b}$ & 255117 & 201777 & 1302 & 382 & 197 \\
\hline Army \#6a (Off-site) & 202887 & 210377 & $\mathrm{n} / \mathrm{a}$ & 382 & 314 \\
\hline UE-20u \#2 & 287769 & 161355 & 1695 & 381 & $\mathrm{n} / \mathrm{a}$ \\
\hline UE-15j \#1 & 272031 & 215135 & 1453 & 381 & $\mathrm{n} / \mathrm{a}$ \\
\hline UE-15j & 272092 & 215135 & 1451 & 380 & $\mathrm{n} / \mathrm{a}$ \\
\hline $\mathrm{UE}-15 \mathrm{j}$ & 272092 & 215135 & 1451 & 380 & $\mathrm{n} / \mathrm{a}$ \\
\hline U-9 ITS UE-U-29 \#1 & 265669 & 208368 & 1295 & 380 & $\mathrm{n} / \mathrm{a}$ \\
\hline UE-8d & 268918 & 204606 & 1353 & 380 & $\mathrm{n} / \mathrm{a}$ \\
\hline UE-5j & 236220 & 208635 & 1091 & 379 & 244 \\
\hline UE-3ct & 255264 & 209345 & 1228 & 375 & $\mathrm{n} / \mathrm{a}$ \\
\hline UE-4aa & 260343 & 203238 & 1297 & 372 & $\mathrm{n} / \mathrm{a}$ \\
\hline Army \#6 (Area 23) & 207507 & 210464 & $\mathrm{n} / \mathrm{a}$ & 372 & $\mathrm{n} / \mathrm{a}$ \\
\hline UE-17a Eleana & 257902 & 196898 & 1432 & 370 & 194 \\
\hline Water Well 5C (Area 5) & 226423 & 215154 & 939 & 366 & 219 \\
\hline $\mathrm{UE}-8 \mathrm{i}$ & 268876 & 202810 & 1392 & 366 & $\mathrm{n} / \mathrm{a}$ \\
\hline MAC Expl. Co \#1 (Area 12) & 270269 & 194655 & 1950 & 366 & $\mathrm{n} / \mathrm{a}$ \\
\hline Marble \#4 (ME-4) & 275685 & 205361 & $\mathrm{n} / \mathrm{a}$ & 362 & 287 \\
\hline UE-4ai & 259911 & 204625 & 1273 & 357 & $\mathrm{n} / \mathrm{a}$ \\
\hline RNM \#2S & 230185 & 214825 & 955 & 352 & 221 \\
\hline J-12 Water Well (Area 25) & 223573 & 177092 & 954 & 347 & 227 \\
\hline UE-5f & 235457 & 216682 & 1006 & 335 & 272 \\
\hline Watertown 2 (Off-site) & 277082 & 229278 & $\mathrm{n} / \mathrm{a}$ & 333 & $\mathrm{n} / \mathrm{a}$ \\
\hline Marble \#3 (ME-3) & 275262 & 205700 & $\mathrm{n} / \mathrm{a}$ & 298 & 145 \\
\hline $\mathrm{UE}-19 \mathrm{~m}$ & 287102 & 178924 & 2049 & 294 & $\mathrm{n} / \mathrm{a}$ \\
\hline UE-1a & 255117 & 201168 & 1312 & 292 & 166 \\
\hline RNM \#2 & 230204 & 214910 & 955 & 285 & $\mathrm{n} / \mathrm{a}$ \\
\hline HTH-5 USGS (Off-site) & 209468 & 185206 & 930 & 282 & $\mathrm{n} / \mathrm{a}$ \\
\hline Water Well 5A (Area 5) & 225052 & 215650 & 943 & 277 & 217 \\
\hline Water Well 5B (Area 5) & 227795 & 214659 & 942 & 274 & 208 \\
\hline Well 1 (Off-site) & 229059 & 220476 & 945 & 265 & $\mathrm{n} / \mathrm{a}$ \\
\hline UE-1d & 255331 & 201488 & 1309 & 261 & $\mathrm{n} / \mathrm{a}$ \\
\hline U-15k Test Hole & 275261 & 206489 & 1575 & 261 & $\mathrm{n} / \mathrm{a}$ \\
\hline Amargosa Tracer \#1 (Off-site) & 198357 & 191825 & 733 & 253 & $\mathrm{n} / \mathrm{a}$ \\
\hline Amargosa Tracer \#2 (Off-site) & 198279 & 191730 & 732 & 252 & $\mathrm{n} / \mathrm{a}$ \\
\hline Army \#3 (Off-site) & 199388 & 231835 & $\mathrm{n} / \mathrm{a}$ & 252 & 88 \\
\hline Amargosa Tracer \#3 (Off-site) & 198341 & 191758 & 732 & 246 & $\mathrm{n} / \mathrm{a}$ \\
\hline $\mathrm{UE}-2 \mathrm{ac}$ & 264414 & 202905 & 1326 & 243 & $\mathrm{n} / \mathrm{a}$ \\
\hline
\end{tabular}


APPENDIX B

EXISTING WELLS AT THE NTS

\begin{tabular}{|c|c|c|c|c|c|}
\hline Well Name & north(m) & east(m) & $\overline{\operatorname{Elev}(m)}$ & $\mathrm{TD}(\mathrm{m})$ & $\mathrm{SWL}(\mathrm{m})$ \\
\hline$\overline{\text { UE-1p Eleana }}$ & $2 \overline{251846}$ & 201868 & 1290 & 238 & $\overline{\mathrm{n} / \mathrm{a}}$ \\
\hline UE-20u \#1 & 287751 & 161342 & 1695 & 228 & $\mathrm{n} / \mathrm{a}$ \\
\hline UE- $-15 j \mathrm{~K}-5$ & 272256 & 215562 & $\mathrm{n} / \mathrm{a}$ & 228 & $\mathrm{n} / \mathrm{a}$ \\
\hline UE-15j A-5 & 271986 & 214852 & $\mathrm{n} / \mathrm{a}$ & 227 & $\mathrm{n} / \mathrm{a}$ \\
\hline UE-13a & 284270 & 209859 & 1466 & 226 & $\mathrm{n} / \mathrm{a}$ \\
\hline UE-1f & 254877 & 201586 & 1304 & 214 & $\mathrm{n} / \mathrm{a}$ \\
\hline Watertown 1 (Off-site) & 277077 & 228462 & $\mathrm{n} / \mathrm{a}$ & 204 & $\mathrm{n} / \mathrm{a}$ \\
\hline $\mathrm{UE}-2 \mathrm{ad}$ & 264261 & 201473 & 1356 & 204 & $\mathrm{n} / \mathrm{a}$ \\
\hline Amargosa Expl. \#3 (Off-site) & 198056 & 191293 & 729 & 203 & $\mathrm{n} / \mathrm{a}$ \\
\hline Amargosa Sample \#1 (Off-site & 198360 & 191782 & 732 & 202 & $\mathrm{n} / \mathrm{a}$ \\
\hline Army \#2 (Off-site) & 199821 & 224078 & $\mathrm{n} / \mathrm{a}$ & 201 & 152 \\
\hline $\mathrm{UE}-15 \mathrm{~g}$ & 274627 & 206558 & 1528 & 200 & $\mathrm{n} / \mathrm{a}$ \\
\hline UE-15f & 274598 & 206626 & 1528 & 199 & $\mathrm{n} / \mathrm{a}$ \\
\hline Test Hole \#2 (Area 3) & 256028 & 211836 & 1267 & 198 & $\mathrm{n} / \mathrm{a}$ \\
\hline Test Hole \#1 (Area 3) & 256028 & 211531 & 1261 & 198 & $\mathrm{n} / \mathrm{a}$ \\
\hline $\mathrm{UE}-2 \mathrm{a}$ & 264443 & 203444 & $\mathrm{n} / \mathrm{a}$ & 191 & $\mathrm{n} / \mathbf{a}$ \\
\hline $\mathrm{U}-12 \mathrm{k} .01-1 \mathrm{R} / \mathrm{C}$ & 274378 & 197586 & 1914 & 190 & $\mathrm{n} / \mathrm{a}$ \\
\hline $\mathrm{UE}-15 \mathrm{~h}$ & 274651 & 206558 & 1528 & 185 & $\mathrm{n} / \mathrm{a}$ \\
\hline U-3ajS-2 & 254879 & 208637 & 1226 & 183 & $\mathrm{n} / \mathrm{a}$ \\
\hline Amargosa Expl. \#1 (Off-site) & 198249 & 190971 & 731 & 183 & $\mathrm{n} / \mathrm{a}$ \\
\hline $\mathrm{U}-2 \mathrm{y} \# 2$ & 265957 & 205769 & 1314 & 181 & $\mathrm{n} / \mathrm{a}$ \\
\hline UE-10 ITS \#1 & 271820 & 207477 & 1367 & 180 & $\mathrm{n} / \mathrm{a}$ \\
\hline BLM (HTH) (Off-site) & 201887 & 222085 & 1112 & 179 & $\mathrm{n} / \mathrm{a}$ \\
\hline UE-17b Eleana & 258841 & 197044 & 1457 & 179 & $\mathrm{n} / \mathrm{a}$ \\
\hline $\mathrm{UE}-12 \mathrm{~g} .10 \# 4$ & 269212 & 192749 & 2307 & 176 & $\mathrm{n} / \mathrm{a}$ \\
\hline UE-17c Eleana & 261348 & 198134 & 1474 & 175 & $\mathrm{n} / \mathrm{a}$ \\
\hline UE-12g.10\#5 & 269210 & 192746 & 2308 & 174 & $\mathrm{n} / \mathrm{a}$ \\
\hline Test Hole \#6 (Area 3) & 256333 & 212141 & 1278 & 174 & $\mathrm{n} / \mathrm{a}$ \\
\hline Watertown 4 (Off-site) & 278751 & 225925 & n/a & 165 & $\mathrm{n} / \mathrm{a}$ \\
\hline Test Hole \#7 (Area 3) & 255723 & 212141 & 1266 & 158 & $\mathrm{n} / \mathrm{a}$ \\
\hline UE-30a \#4 (WES Hole 66-4) & 250509 & 178710 & $\mathrm{n} / \mathrm{a}$ & 158 & $\mathrm{n} / \mathrm{a}$ \\
\hline UE-1m Eleana & 251584 & 200510 & 1365 & 157 & $\mathbf{n} / \mathbf{a}$ \\
\hline Test Hole \#8 (Area 3) & 255419 & 212141 & 1260 & 155 & $\mathrm{n} / \mathrm{a}$ \\
\hline Test Hole \#5 (Area 3) & 256638 & 212141 & 1284 & 154 & $\mathrm{n} / \mathrm{a}$ \\
\hline Jangle Test Hole \#A3 & 268894 & 207751 & $\mathrm{n} / \mathrm{a}$ & 153 & $\mathrm{n} / \mathrm{a}$ \\
\hline $\mathrm{UE}-20 \mathrm{u} \# 3$ & 287786 & 161367 & 1695 & 152 & $\mathrm{n} / \mathrm{a}$ \\
\hline $\mathrm{U}-3 \mathrm{bc} \# 2$ & 254728 & 208468 & 1225 & 152 & $\mathrm{n} / \mathrm{a}$ \\
\hline Jangle Test Hole \#A4 & 268589 & 207385 & $\mathrm{n} / \mathrm{a}$ & 152 & $\mathrm{n} / \mathrm{a}$ \\
\hline $\mathrm{UE}-15 \mathrm{j} \mathrm{D}-1$ & 271782 & 215172 & $\mathbf{n} / \mathbf{a}$ & 152 & $\mathrm{n} / \mathrm{a}$ \\
\hline Test Hole \#3 (Area 3) & 256028 & 212445 & 1276 & 145 & $\mathrm{n} / \mathrm{a}$ \\
\hline
\end{tabular}




\section{APPENDIX B}

EXISTING WELLS AT THE NTS

\begin{tabular}{|c|c|c|c|c|c|}
\hline Well Name & north $(\mathrm{m})$ & east(m) & $\operatorname{Elev}(\mathrm{m})$ & $\mathrm{TD}(\mathrm{m})$ & SWL(m) \\
\hline Test Hole \#5 & 223966 & 210349 & 985 & 141 & $\overline{\mathrm{n} / \mathrm{a}}$ \\
\hline U-10am \#5 Experimental Hole & 268787 & 204764 & 1349 & 138 & $\mathrm{n} / \mathrm{a}$ \\
\hline UE-18e \#1 & 268159 & 184919 & 1806 & 137 & $\mathrm{n} / \mathrm{a}$ \\
\hline$U E-15 j \mathrm{D}-9$ & 272365 & 214955 & $\mathbf{n} / \mathbf{a}$ & 137 & $\mathrm{n} / \mathrm{a}$ \\
\hline UE-17d Eleana & 258223 & 197445 & 1426 & 121 & $\mathrm{n} / \mathrm{a}$ \\
\hline $\mathrm{UE}-15 \mathrm{j} \mathrm{I}-5$ & 272202 & 215420 & $\mathrm{n} / \mathrm{a}$ & 119 & $\mathrm{n} / \mathrm{a}$ \\
\hline Marble \#1 (ME-1) & 275074 & 205840 & $\mathrm{n} / \mathrm{a}$ & 115 & $\mathrm{n} / \mathrm{a}$ \\
\hline Watertown 3 (Off-site) & 278889 & 226244 & $\mathrm{n} / \mathbf{a}$ & 113 & $\mathrm{n} / \mathrm{a}$ \\
\hline UE-16b Eleana & 255879 & 195482 & 1490 & 110 & $\mathrm{n} / \mathrm{a}$ \\
\hline $\mathrm{UE}-15 \mathrm{j} \mathrm{C}-5$ & 272039 & 214992 & $\mathrm{n} / \mathrm{a}$ & 102 & $\mathrm{n} / \mathrm{a}$ \\
\hline Stewart 1 (Off-site) & 280568 & 214647 & $\mathrm{n} / \mathrm{a}$ & 102 & $\mathrm{n} / \mathrm{a}$ \\
\hline UE-20ba \#2 & 277255 & 166570 & 1900 & 101 & $\mathrm{n} / \mathrm{a}$ \\
\hline UE-20ba \#1 & 277256 & 166606 & 1900 & 101 & $\mathrm{n} / \mathrm{a}$ \\
\hline $\mathrm{U}-30 \mathrm{NX} \# 1$ & 250556 & 178732 & 1588 & 100 & $\mathrm{n} / \mathrm{a}$ \\
\hline $\mathrm{U}-30 \mathrm{NX} \# 8$ & 250569 & 178602 & 1587 & 99 & $\mathrm{n} / \mathrm{a}$ \\
\hline UE-20k \#1 & 280772 & 165090 & 1888 & 96 & $\mathrm{n} / \mathrm{a}$ \\
\hline UE-10 ITS \#3 & 270418 & 207477 & 1327 & 90 & $\mathrm{n} / \mathrm{a}$ \\
\hline Marble \#2 (ME-2) & 275440 & 205997 & $\mathrm{n} / \mathrm{a}$ & 84 & $\mathrm{n} / \mathrm{a}$ \\
\hline $\mathrm{UE}-18 \mathrm{e} \# 2$ & 268134 & 184931 & 1804 & 83 & $\mathrm{n} / \mathrm{a}$ \\
\hline UE-20k \#3 & 280717 & 165049 & 1884 & 82 & $\mathrm{n} / \mathrm{a}$ \\
\hline UE-20k \#2 & 280731 & 165164 & 1885 & 82 & $\mathrm{n} / \mathrm{a}$ \\
\hline UE-18e \#3 & 268095 & 184878 & 1806 & 77 & $\mathrm{n} / \mathrm{a}$ \\
\hline UE-18e \#5 & 268179 & 184886 & 1811 & 76 & $\mathrm{n} / \mathrm{a}$ \\
\hline $\mathrm{UE}-18 \mathrm{e} \# 4$ & 268188 & 184945 & 1804 & 73 & $\mathrm{n} / \mathrm{a}$ \\
\hline Wes Hole 66-2 (Area 12) & 275725 & 193802 & $\mathrm{n} / \mathrm{a}$ & 67 & $\mathrm{n} / \mathrm{a}$ \\
\hline UE-30a \#5 (WES Hole 66-5) & 250478 & 178866 & $\mathrm{n} / \mathrm{a}$ & 68 & $\mathrm{n} / \mathrm{a}$ \\
\hline UE-30a \#3 (WES Hole 66-3) & 268840 & 178325 & $\mathrm{n} / \mathrm{a}$ & 69 & $\mathrm{n} / \mathrm{a}$ \\
\hline Stewart 2 (Off-site) & 284360 & 218860 & $\mathrm{n} / \mathrm{a}$ & 67 & $\mathrm{n} / \mathrm{a}$ \\
\hline $\mathrm{U}-30 \mathrm{NX} \# 9$ & 250581 & 178571 & 1588 & 67 & $\mathrm{n} / \mathrm{a}$ \\
\hline $\mathrm{U}-30 \mathrm{NX} \# 5$ & 250618 & 178754 & 1584 & 67 & $\mathrm{n} / \mathrm{a}$ \\
\hline J-11 Prime (Area 25) & 225823 & 186483 & $\mathrm{n} / \mathrm{a}$ & 67 & $\mathrm{n} / \mathrm{a}$ \\
\hline $\mathrm{U}-30 \mathrm{NX} \# 6$ & 250648 & 178765 & 1583 & 67 & $\mathrm{n} / \mathrm{a}$ \\
\hline UE-20k \#5 & 280786 & 165066 & 1888 & 66 & $\mathrm{n} / \mathrm{a}$ \\
\hline UE-29a \#1 & 243147 & 178483 & 1215 & 66 & $\mathrm{n} / \mathrm{a}$ \\
\hline $\mathrm{U}-30 \mathrm{NX} \# 3$ & 250588 & 178742 & 1586 & 61 & $\mathrm{n} / \mathrm{a}$ \\
\hline $\mathrm{U}-30 \mathrm{NX} \# 4$ & 250588 & 178743 & 1586 & 61 & $\mathrm{n} / \mathrm{a}$ \\
\hline Effinger \#3 (Area 12) & 271584 & 198947 & 1534 & 61 & $\mathrm{n} / \mathrm{a}$ \\
\hline $\mathrm{UE}-20 \mathrm{k} \# 4$ & 280803 & 165090 & 1887 & 61 & $\mathrm{n} / \mathrm{a}$ \\
\hline Effinger \#1 (Area 12) & 270833 & 198243 & 1570 & 55 & $\mathrm{n} / \mathrm{a}$ \\
\hline Jangle Test Hole \#A2 (Area 2) & 267187 & 205374 & $\mathrm{n} / \mathrm{a}$ & 54 & $\mathrm{n} / \mathrm{a}$ \\
\hline
\end{tabular}


APPENDIX B

EXISTING WELLS AT THE NTS

\begin{tabular}{|c|c|c|c|c|c|}
\hline Well Name & north $(\mathrm{m})$ & east(m) & Elev(m) & $\mathrm{TD}(\mathrm{m})$ & SWL(m) \\
\hline Test Hole \#4 & 232839 & 210175 & 1038 & 52 & $\mathrm{n} / \mathrm{a}$ \\
\hline UE-15i (DPNE) & 274997 & 213432 & 1421 & 50 & $\mathrm{n} / \mathrm{a}$ \\
\hline Area 2 Test Well & $\mathrm{n} / \mathrm{a}$ & $\mathrm{n} / \mathrm{a}$ & $\mathrm{n} / \mathrm{a}$ & 50 & $\mathrm{n} / \mathrm{a}$ \\
\hline $\mathrm{U}-3 \mathrm{fd} \mathrm{N} 1$ & $\mathrm{n} / \mathrm{a}$ & $\mathrm{n} / \mathrm{a}$ & $\mathrm{n} / \mathrm{a}$ & 46 & $\mathrm{n} / \mathrm{a}$ \\
\hline $\mathrm{UE}-23 \mathrm{q}$ & $\mathrm{n} / \mathrm{a}$ & $\mathrm{n} / \mathrm{a}$ & $\mathrm{n} / \mathrm{a}$ & 46 & $\mathrm{n} / \mathrm{a}$ \\
\hline U-5 RNM \#5 & 229823 & 215305 & 948 & 46 & $\mathrm{n} / \mathrm{a}$ \\
\hline $\mathrm{U}-30 \mathrm{NX} \# 7$ & 250710 & 178789 & 1581 & 46 & $\mathrm{n} / \mathrm{a}$ \\
\hline U-30 NX \#15 & 250501 & 178783 & 1588 & 46 & $\mathrm{n} / \mathrm{a}$ \\
\hline $\mathrm{U}-30 \mathrm{NX} \# 10$ & 250603 & 178511 & 1588 & 46 & $\mathrm{n} / \mathrm{a}$ \\
\hline $\mathrm{U}-30 \mathrm{NX} \# 2$ & 250587 & 178742 & 1586 & 44 & $\mathrm{n} / \mathrm{a}$ \\
\hline Gravity High \#1 (Area 2) & 266090 & 201991 & 1353 & 44 & $\mathrm{n} / \mathrm{a}$ \\
\hline UE-16c Eleana & 257543 & 196461 & 1440 & 44 & $\mathrm{n} / \mathrm{a}$ \\
\hline U-5 Seismic \#2 & 228485 & 203643 & 1179 & 43 & $\mathrm{n} / \mathrm{a}$ \\
\hline U-5 Seismic \#1 & 228480 & 203636 & 1179 & 43 & $\mathrm{n} / \mathrm{a}$ \\
\hline $\mathrm{UE}-3 \mathrm{~d}$ & 252887 & 209316 & n/a & 37 & $\mathrm{n} / \mathrm{a}$ \\
\hline SI-3 (Area 17) & 260095 & 197050 & 1503 & 35 & $\mathrm{n} / \mathrm{a}$ \\
\hline SI-1 (Area 17) & 260095 & 197049 & 1503 & 34 & $\mathrm{n} / \mathrm{a}$ \\
\hline U-2ax Test Hole (Perm) & 266612 & 203879 & 1344 & 32 & $\mathrm{n} / \mathrm{a}$ \\
\hline UE-17g Eleana & 260083 & 197057 & 1502 & 32 & $\mathrm{n} / \mathrm{a}$ \\
\hline $\mathrm{U}-3 \mathrm{fd} \mathrm{N} 2$ & $\mathrm{n} / \mathrm{a}$ & $\mathrm{n} / \mathrm{a}$ & $\mathrm{n} / \mathrm{a}$ & 31 & $\mathrm{n} / \mathrm{a}$ \\
\hline UE-17f Eleana & 260092 & 196910 & 1503 & 30 & $\mathrm{n} / \mathrm{a}$ \\
\hline SI-4 (Area 17) & 260095 & 197048 & 1503 & 28 & $\mathrm{n} / \mathrm{a}$ \\
\hline SI-2 (Area 17) & 260095 & 197049 & 1503 & 28 & $\mathrm{n} / \mathrm{a}$ \\
\hline Gravity High \#2 (Area 2) & 254447 & 204718 & 1256 & 28 & $\mathrm{n} / \mathrm{a}$ \\
\hline WES Hole 66-1 (Area 12) & 275860 & 192722 & $\mathrm{n} / \mathrm{a}$ & 27 & $\mathrm{n} / \mathrm{a}$ \\
\hline SI-13 (Area 17) & 260098 & 197049 & 1503 & 25 & $\mathrm{n} / \mathrm{a}$ \\
\hline SI-10 (Area 17) & 260097 & 197049 & 1503 & 25 & $\mathrm{n} / \mathrm{a}$ \\
\hline Whiterock Springs-2 & 272247 & 199979 & $\mathrm{n} / \mathrm{a}$ & 26 & $\mathrm{n} / \mathrm{a}$ \\
\hline SI-16 (Area 17) & 260108 & 197051 & 1503 & 26 & $\mathrm{n} / \mathrm{a}$ \\
\hline SI-5 (Area 17) & 260096 & 197049 & 1503 & 25 & $\mathrm{n} / \mathrm{a}$ \\
\hline SI-7 (Area 17) & 260093 & 197049 & 1503 & 25 & $\mathrm{n} / \mathrm{a}$ \\
\hline SI-11 (Area 17) & 260092 & 197048 & 1503 & 25 & $\mathrm{n} / \mathrm{a}$ \\
\hline UE-10 ITS \#2 & 271822 & 209398 & 1379 & 25 & $\mathrm{n} / \mathrm{a}$ \\
\hline Test Hole \#5 (Area 17) & 260102 & 197050 & 1503 & 24 & $\mathrm{n} / \mathrm{a}$ \\
\hline Test Hole \#4 (Area 17) & 260101 & 197050 & 1503 & 24 & $\mathrm{n} / \mathrm{a}$ \\
\hline SI-9 (Area 17) & 260095 & 197048 & 1503 & 24 & $\mathrm{n} / \mathrm{a}$ \\
\hline SI-6 (Area 17) & 260094 & 197050 & 1503 & 24 & $\mathrm{n} / \mathrm{a}$ \\
\hline SI-14 (Area 17) & 260094 & 197052 & 1503 & 24 & $\mathrm{n} / \mathrm{a}$ \\
\hline Effinger \#2 (Area 12) & 270139 & 196013 & 1706 & 24 & $\mathrm{n} / \mathrm{a}$ \\
\hline SI-8 (Area 17) & 260094 & 197048 & 1503 & 24 & $\mathrm{n} / \mathrm{a}$ \\
\hline
\end{tabular}




\section{APPENDIX B}

EXISTING WELLS AT THE NTS

\begin{tabular}{lccrrc}
\hline \multicolumn{1}{c}{ Well Name } & north $(\mathrm{m})$ & east(m) & Elev(m) & TD(m) & SWL(m) \\
\hline \hline SI-15 (Area 17) & 260095 & 197046 & 1503 & 24 & $\mathrm{n} / \mathrm{a}$ \\
SI-12 (Area 17) & 260095 & 197047 & 1503 & 24 & $\mathrm{n} / \mathrm{a}$ \\
Effinger \#4 (Area 12) & 270060 & 196052 & 1708 & 23 & $\mathrm{n} / \mathrm{a}$ \\
Whiterock Springs-1 & 272064 & 199857 & $\mathrm{n} / \mathrm{a}$ & 22 & $\mathrm{n} / \mathrm{a}$ \\
Whiterock Springs-4 & 271576 & 200040 & $\mathrm{n} / \mathrm{a}$ & 22 & $\mathrm{n} / \mathrm{a}$ \\
UE-10 ITS \#6 & 271058 & 207355 & $\mathrm{n} / \mathrm{a}$ & 21 & $\mathrm{n} / \mathrm{a}$ \\
U-30 NX \#14 & 250740 & 178800 & 1580 & 18 & $\mathrm{n} / \mathrm{a}$ \\
U-30 NX \#13 & 250709 & 178790 & 1581 & 18 & $\mathrm{n} / \mathrm{a}$ \\
U-30 NX \#12 & 250679 & 178777 & 1583 & 18 & $\mathrm{n} / \mathrm{a}$ \\
SI-8A (Area 17) & 260093 & 197046 & 1503 & 18 & $\mathrm{n} / \mathrm{a}$ \\
SI-11A (Area 17) & 260091 & 197048 & 1503 & 18 & $\mathrm{n} / \mathrm{a}$ \\
U-30 NX \#11 & 250649 & 178764 & 1583 & 18 & $\mathrm{n} / \mathrm{a}$ \\
Whiterock Springs-3 & 271881 & 199857 & $\mathrm{n} / \mathrm{a}$ & 12 & $\mathrm{n} / \mathrm{a}$ \\
UE-15j G-2 & 271934 & 215359 & $\mathrm{n} / \mathrm{a}$ & 9 & $\mathrm{n} / \mathrm{a}$ \\
UE-15j F-5 & 272111 & 215178 & $\mathrm{n} / \mathrm{a}$ & 8 & $\mathrm{n} / \mathrm{a}$ \\
UE-15j E-5 & 272116 & 215193 & $\mathrm{n} / \mathrm{a}$ & 5 & $\mathrm{n} / \mathrm{a}$ \\
Whiterock Springs-3A & 271912 & 199948 & $\mathrm{n} / \mathrm{a}$ & 3 & $\mathrm{n} / \mathrm{a}$ \\
UE-15j \#1 & 272031 & 215135 & 381 & $\mathrm{n} / \mathrm{a}$ & $\mathrm{n} / \mathrm{a}$ \\
\hline
\end{tabular}




\section{APPENDIX C \\ LITHOLOGIC SYMBOLS USED IN CROSS SECTIONS AND WELL DIAGRAMS}

LITHOLOGIC SYMBOL

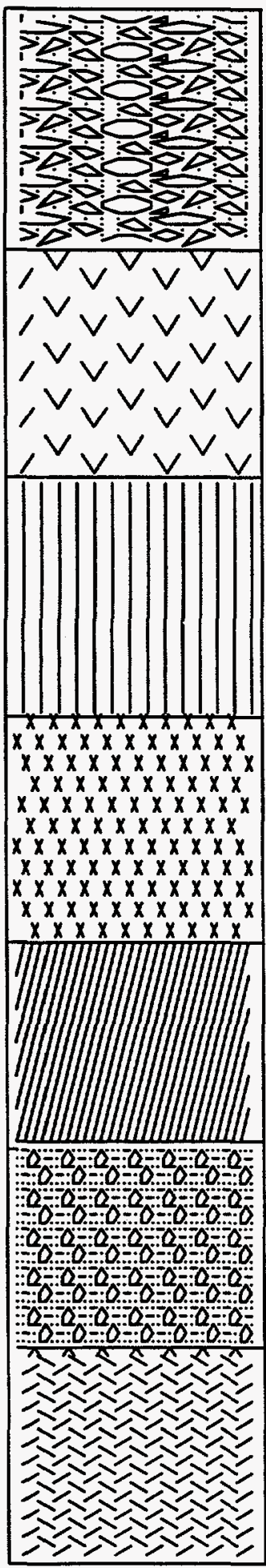

GENERAL ROCK TYPE

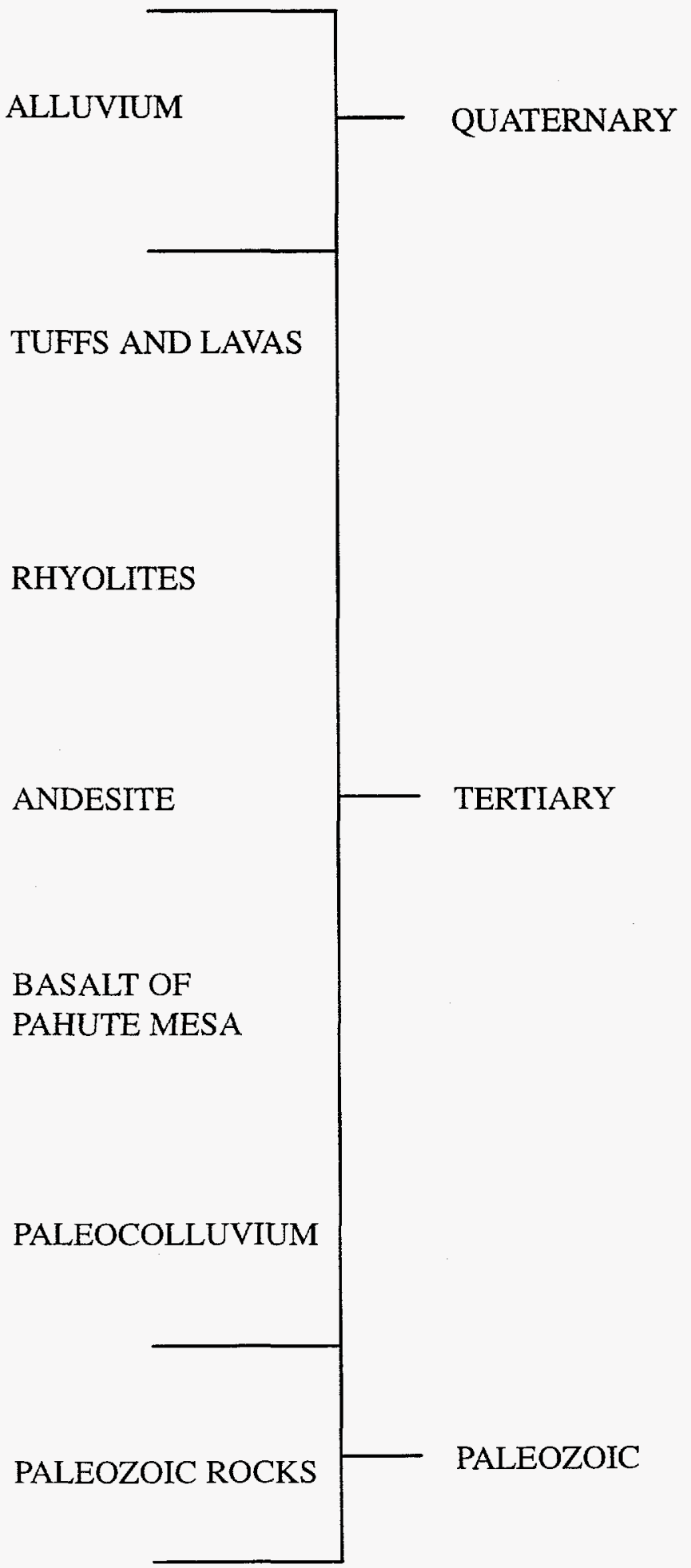




\section{APPENDIX D}

STRATIGRAPHIC NOMENCLATURE USED IN HOLE DIAGRAMS

\begin{tabular}{ll}
\hline \hline Pz & Paleozoic Rocks - Unidentified \\
Pzc & Paleozoic Carbonates \\
Pzq & Paleozoic Quartzites \\
Pzt & Colluvium \\
Qal & Alluvium, Undivided \\
Tab & Bedded Tuffs (Peralkaline) \\
Tac & Calico Hills Rhyolite \\
Tan & Ash-fall and Nonwelded Tuff (Post Timber Mountain) \\
Tat & Vitric Bedded, Ash-fall, and Reworked Tuff (Post Timber Mountain) \\
Tb & Belted Range Rhyolite \\
Tbdx & Landslide Breccia \\
Tbg & Bedded Grouse Canyon Tuff \\
Tbgb & Comendite of Basket Valley \\
Tbt & Tub Spring Tuff \\
Tc & Crater Flat Tuff, Undifferentiated \\
Tca & Andesite \\
Tcb & Bullfrog Tuff \\
Tcf & Crater Flat Tuff \\
Tcpu & Mafic-poor Prow Pass \\
Tf & Fraction Tuff \\
Tfbw & Beatty Wash Rhyolite \\
TiC & Paleocolluvium (Tuffaceous) \\
Tma & Ammonia Tanks Tuff \\
Tmab & Bedded Ammonia Tanks Tuff \\
Tmb & Timber Mountain Bedded Tuff \\
Tmr & Rainier Mesa Tuff \\
Tmrl & Timber Mountain Tuff, Rainier Mesa Member, Lower \\
Tmpr & Pre-Rainier Mesa Rhyolite \\
Tnb & Basalt of Pahute Mesa \\
Tnp & Pool Unit \\
Tnqr & Quartz Rhyolite of Scrugham Peak Quad \\
Tot1 & \\
Tot2 Undiff. & Pre-Redrock Valley Post-fraction Bedded Tuffs \\
\hline \hline &
\end{tabular}


STRATIGRAPHIC NOMENCLATURE USED IN HOLE DIAGRAMS (Cont.)

\begin{tabular}{ll}
\hline \hline Tp & Paintbrush Tuff \\
Tpc & Paintbrush Tuff, Tiva Canyon Member \\
Tppr & Pyroxene Rhyolite of Scrugham Peak Quad \\
Tprp & Pre-Pah Canyon Rhyolite \\
Tra & Tuffs and Lavas of Area 20 \\
Trab & Area 20 Tuffs and Lavas, Bedded and Ash Flows \\
Tral & Area 20 Tuffs and Lavas, Lower Lava Unit \\
Trat & Area 20 Tuffs and Lavas, Lithic-rich Tuff \\
Trq & Rhyolite Lava of Quartet Dome \\
Trv & Redrock Valley Tuff \\
Tt & Thirsty Canyon Tuffs \\
Tt1 & Tunnel Bed 1 \\
Tt2 & Tunnel Bed 2 \\
Tt3 & Tunnel Beds, Unit 3 \\
Tt3BC & Tunnel Beds, Subunit 3bc \\
Tt4 & Tunnel Beds, Unit 4 \\
Tt4E & Tunnel Beds, Subunit 4e \\
Ttl & Thirsty Canyon, Lower Tuff \\
Ttp & Thirsty Canyon, Pahute Mesa Member \\
Ttr & Thirsty Canyon, Rocket Wash Member \\
Ttt & Thirsty Canyon, Trail Ridge Member \\
Ttu & Tunnel Beds, Undifferentiated \\
Tw & Wahmonie Tuff \\
Tx Undiff. & Pre-Rainier Mesa, Post-Wahmonie Bedded Tuffs \\
Tyf & Yucca Flat Tuff \\
Unk & Unknown Tuffs \\
\hline \hline
\end{tabular}




\section{DISTRIBUTION}

Bob Bangerter

Environmental Restoration Division

Nevada Operations Office

U.S. Department of Energy

P.O. Box 98518

Las Vegas, NV 89193-8518

Dave Beck

U.S. Geological Survey

Water Resources Division

6770 S. Paradise Rd.

Las Vegas, NV 89119

Ron Baugh

Bechtel Nevada

P.O. Box 98521

Las Vegas, NV 89193-8521

Joanne M. Bradbery, Director

Contract Management Division

Nevada Operations Office

U.S. Department of Energy

P.O. Box 98518

Las Vegas, NV 89193-8518

Beverly Colbert

Contract Management Division

Nevada Operations Office

U.S. Department of Energy

P.O. Box 98518

Las Vegas, NV 89193-8518

Lee Davisson

Nuclear Chemistry Division

Lawrence Livermore National Laboratory

P.O. Box 808 , L-237

Livermore, CA 94550

Brian Dozier

Bechtel Nevada

P.O. Box 98521

Las Vegas, NV 89193-8521
Doug Duncan

Environmental Protection Division

Nevada Operations Office

U.S. Department of Energy

P.O. Box 98518

Las Vegas, NV 89193-8518

Dennis Farmer

Radiation Sciences Laboratory

Office of Radiation and Indoor Air

U.S. Environmental Protection Agency

P.O. Box 98517 , M/S 513

Las Vegas, NV 89193-8517

Larry Franks

Nevada State Health Department

Radiological Health Section

620 Belrose Avenue

Las Vegas, NV 89158

Wayne Glines

Bechtel Nevada

P.O. Box 98521

Las Vegas, NV 89193-8521

Laura Helfel

State of Nevada

Department of Conservation

and Natural Resources

Division of Environmental Protection

333 W. Nye Lane

Carson City, NV 89710

Kenneth Hoar, Director

Environmental Protection Division

Nevada Operations Office

U.S. Department of Energy

P.O. Box 98518

Las Vegas, NV 89193-8518

Deborah Howard

Environmental Protection Division

Nevada Operations Office

U.S. Department of Energy

P.O. Box 98518

Las Vegas, NV 89193-8518 
Kathy Izell

Assistant Manager for Technical Services

Nevada Operations Office

U.S. Department of Energy

P.O. Box 98518

Las Vegas, NV 89193-8518

Roger Jacobson

Desert Research Institute

Water Resources Center

P.O. Box 19040

Las Vegas, NV 89132-0040

Marjory Jones

Desert Research Institute

Water Resources Center

P.O. Box 60220

Reno, NV 89506-0220

Annie Kersting

Lawrence Livermore National Laboratory

Isotope Sciences Division

L-213

P.O. Box 808

Livermore, CA 94550

Randy Laczniak

U.S. Geological Survey

Water Resources Division

6770 S. Paradise Rd.

Las Vegas, NV 89119

Steve Mellington, Director

Environmental Restoration Division

Nevada Operations Office

U.S. Department of Energy

P.O. Box 98518

Las Vegas, NV 89193-8518

Leslie A. Monroe

Environmental Protection Division

Nevada Operations Office

U.S. Department of Energy

P.O. Box 98518

Las Vegas, NV 89193-8518
Ken Rehfeldt

Geotrans, c/o IT

4330 Valley View

Suite 112, MS-439

Las Vegas, NV 89103

Mike Sabbe

Bechtel Nevada

P.O. Box 98521

Las Vegas, NV 89193-8521

David K. Smith

Isotopes Sciences Division

Lawrence Livermore National Laboratory

P.O. Box 808, M/S L231

Livermore, CA 94550

Nick Stellevato

Nuclear Waste Repository Project Office

P.O. Box 675

Mercury, NV 89023

Bonnie Thompson

Environmental Protection Division

Nevada Operations Office

U.S. Department of Energy

P.O. Box 98518

Las Vegas, NV 89193-8518

Joe Thompson

Los Alamos National Laboratory

INC-11, MS J514

P.O. Box 1663

Los Alamos, NM 87545

Doug Trudeau

U.S. Geological Survey

Water Resources Division

6770 S. Paradise Rd.

Las Vegas, NV 89119

Steve Wiel

Bechtel Nevada

P.O. Box 98521

Las Vegas, NV 89193-8521

Janet Wille

International Technology Corporation

P.O. Box 93838

Bldg. B-1, M/S 439

Las Vegas, NV 89103-3838 
Annie Kelley

State Documents Department

Nevada State Library

Capitol Complex

Carson City, NV 89710

Archives

Getchell Library

University of Nevada, Reno

Beverly Carter

MacKay School of Mines Library

University of Nevada, Reno

Document Section, Library

University of Nevada, Las Vegas

4505 Maryland Parkway

Las Vegas, NV 89154

Library (Stead)

Desert Research Institute

P.O. Box 60220

Reno, Nevada 89506-0220

Library

IT Corporation

Bldg. B-1

P.O. Box 93838, M/S 439

Las Vegas, NV 89193-3838

ATTN: Toni Miller, M/S 439
Library

Southern Nevada Science Center

Desert Research Institute

P.O. Box 19040

Las Vegas, NV 89132-0040

Public Reading Facility

Bechtel Nevada

P.O. Box 98521

Las Vegas, NV 89193-8521

Technical Information Resource Center

Nevada Operations Office

U.S. Department of Energy

P.O. Box 98518

Las Vegas, NV 89193-8518

Nevada State Library and Archives

State Publications

100 North Stewart Street

Carson City, NV 89701-4285

Librarian

Water Resources Center Archives

$410 O^{\prime}$ Brien Hall

University of California

Berkeley, CA 94720-1718

Office of Scientific and Technical Information

U.S. Department of Energy

P.O. Box 62

Oak Ridge, TN 37831-9939 